\title{
Qualidade de Vida em Crianças e Adolescentes com HIV/AIDS \\ Validação e Reprodutibilidade de Instrumentos
}

\author{
Luciana Scarlazzari Costa
}

Tese apresentada ao Programa de PósGraduação em Saúde Pública para obtenção do título de Doutor em Saúde Pública.

Área de Concentração: Epidemiologia

Orientador: Prof ${ }^{a}$ Dra Maria do Rosário Dias de Oliveira Latorre

Co-orientadora: Dra Heloísa Helena de Souza Marques

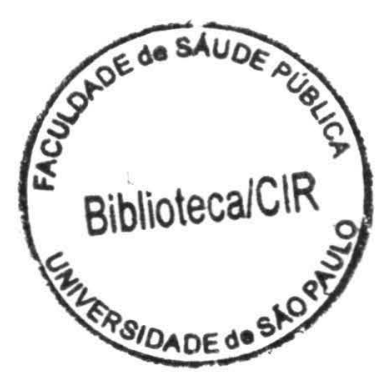

São Paulo

2007 
É expressamente proibida a comercialização deste documento tanto na sua forma impressa como eletrônica. Sua reprodução total ou parcial é permitida exclusivamente para fins acadêmicos e científicos, desde que na reprodução figure a identificação do autor, título, instituição e ano da tese.

$$
49004 / 2007 \text { doc }
$$


Financiamento de Bolsa de Doutorado:

Fundação de Amparo à Pesquisa do Estado de São Paulo

Processo no ${ }^{04 / 00886-0}$

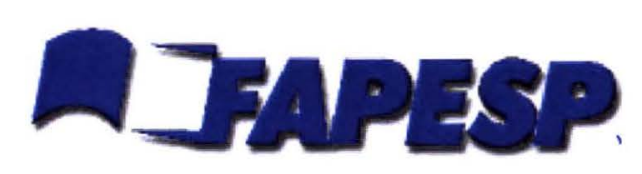


Este trabalho é dedicado a todas as crianças e adolescente que convivem com HIV/Aids. 


\section{AGRADECIMENTOS}

À minha muito querida orientadora, Prof. Dra. Maria do Rosário Dias de Oliveira Latorre, pessoa que muito admiro e que sempre me acolheu com muita paciência e disposição nas várias fases do doutorado, fazendo o papel de mãe, irmã e amiga. Não tenho palavras para demonstrar a minha gratidão.

Aos meus queridos pais, Antonio e Esther, pelo suporte emocional e financeiro, exemplos de pessoas a quem dedico toda a minha tragetória de vida.

À minha irmã Cheila, minha segunda mãe..., pelo carinho e ajuda sempre pronta.

Ao meu marido, Jaime, pelo amor e apoio em muitos momentos.

Aos meus filhos Stella e Ciro, simplesmente por existirem. Duas estrelas que iluminam o caminho da minha vida.

À minha querida co-orientadora, Dra. Heloísa Helena de Souza Marques, pela disposição em ajudar nas várias fases deste trabalho.

Aos professores Ivan França Júnior, Michael Eduardo Reichenheim, Kátia Cristina Bassicheto e Maria Zilda Aquino, pelas valiosas contribuições a este trabalho.

À Mariliza Henrique da Silva, diretora do Hospital Dia do Referência e Treinamento em DST/AIDS de São Paulo, pessoa fundamental para a realização deste trabalho e que me acolheu com muita simpatia.

Aos médicos Sidnei Rana Pimentel, Daniela Vinhas Bertolini e Daisy Maria Machado pela colaboração no início e decorrer do estudo. 
Aos pais, cuidadores, crianças e adolescentes do CRT/SP, com quem pude partilhar um pouquinho da minha vida. Obrigada pela ajuda na realização do trabalho, ele nada seria sem vocês.

À minhas queridas companheiras da Faculdade de Saúde Pública, em especial à Stela, Carmen, Aline, Fernanda, Maria, Micheline, Márcia Holcman, Márcia Simões e Tatiana pela amizade e alegria.

Ao Programa de Pós-Graduação da Faculdade de Saúde Pública por me proporcionar a oportunidade de realização do doutorado. 
“ Eu considero uma boa qualidade de vida uma boa alimentação, é um bom relacionamento com a família, né? E assim uma criança alegre, né? Que tenha assim quase uma vida normal como as outras, né? Não deixando, não excluindo, não fazendo ela se sentir uma criança totalmente diferente das outras, né? Se sentir uma criança normal como outra qualquer, indo a escola, brincando, com uma boa alimentação e assim com muita alegria, né? E com muito amor dos familiares, isso pra mim é uma boa qualidade de vida".

(Relato sobre qualidade de vida de um responsável pela criança que participou do estudo) 
Costa LS. Qualidade de Vida em Crianças e Adolescentes com HIV/Aids. Validação e reprodutibilidade de instrumentos. [Tese de doutorado]. São Paulo: Faculdade de Saúde Pública da USP; 2007

\section{RESUMO}

Introdução - Qualidade de vida relacionada à saúde e adesão ao uso de medicamentos em crianças/adolescentes são questões importantes que têm sido estudadas em países desenvolvidos, utilizando, fundamentalmente, questionários que ainda não foram traduzidos e/ou validados no Brasil. Objetivos - 1) Traduzir e validar o questionário Quality of Life Assessment (QLA), específico para crianças e adolescentes com HIV/Aids, e avaliar a sua reprodutibilidade. 2) Validar um questionário sobre expectativa de auto-eficácia para seguir prescrição anti-retroviral em crianças e adolescentes com HIV/Aids e avaliar a sua reprodutibilidade. Métodos - O estudo foi realizado no Centro de Referência e Treinamento em DST/AIDS de São Paulo (CRT/SP). Participaram do estudo 90 crianças e adolescentes de 6 meses a 20 anos que passaram em consulta de rotina pelo serviço. Os dados de qualidade de vida foram coletados por meio dos questionários de Avaliação da Qualidade de Vida (AQV) com 3 versões para 3 faixas etárias específicas (6 meses a 4 anos, 5 a 11 e 12 a 20 anos) e, os de auto-eficácia, pela Escala de Auto-Eficácia para seguir Prescrição Anti-Retroviral (AE). Foi realizada a avaliação de equivalência transcultural do QLA. A consistência interna dos questionários foi verificada pelo cálculo do coeficiente $\alpha$ de Cronbach. Foi realizada análise fatorial confirmatória para o questionário AQV e exploratória para o de AE. A validade de constructo foi avaliada pela comparação das médias dos escores entre grupos do Center for Disease Control (teste de Mann-Whitney) para o AQV, e entre grupos aderentes e não aderentes ao tratamento anti-retroviral para a escala $\mathrm{AE}$ e, também, pela análise da correlação entre os escores de $\mathrm{AQV}$ e de $\mathrm{AE}$ e marcadores clínicos e de utilização dos serviços de saúde. A reprodutibilidade foi verificada por meio do teste de comparação de médias entre escores em dois momentos (pareado), pelo coeficiente de correlação intra-classe $\left(r_{\text {icc }}\right.$ ) e pelo método de Bland-Altman. Resultados - Como primeiro produto do trabalho tem-se a versão em português 'do QLA. O AQV apresentou melhores consistências internas nas faixas etárias de 5 a 11 anos e 12 a 20 anos. A consistência interna da escala de AE foi boa em todas as faixas etárias e na amostra total. A análise fatorial confirmatória mostrou que é possível uma redução no número de questões do questionário $\mathrm{AQV}$. Na faixa etária de 6 meses a 4 anos, o AQV discriminou grupos somente no domínio de Estado Físico e houve correlações significativas com marcadores clínicos e de utilização dos serviços de saúde nos domínios de Resistência Física, Atividades Pessoais e sociais, Utilização dos Serviços de Saúde e Sintomas ou Sinais. Na faixa etária de 5 a 11 anos, o AQV apresentou capacidade discriminante nos domínios de Avaliação Geral da Saúde, Estado Físico, Saúde Psicológica e Sintomas ou Sinais. Foram obtidas correlações estatisticamente significativas entre o número de visitas ao médico e o domínio de Utilização dos Serviços de Saúde. Na faixa etária de 12 a 20 anos do AQV houve capacidade 
discriminante no domínio de Sintomas ou Sinais e apresentou correlações significativas com marcadores clínicos e de utilização dos serviços de saúde nos domínios de Avaliação Geral da Saúde, Atividades Pessoais e Sociais, Utilização dos Serviços de Saúde e Sintomas ou Sinais. A escala de AE conseguiu discriminar grupos clinicamente diferentes. Foi obtida boa reprodutibilidade tanto para o questionário QLA quanto para a escala de AE. Conclusão - O questionário de AQV e a escala de $\mathrm{AE}$ podem ser utilizados para avaliar a qualidade de vida e a auto-eficácia em crianças e adolescentes com HIV/Aids, mas sugere-se que novos estudos devam ser feitos para aprimorar o QLA.

Descritores: qualidade de vida, criança, adolescente, HIV, AIDS, estudos de validação. 
Costa LS. Quality of Life in Children and Adolescents with HIV/Aids. Instrument's Validity and Reliability. [Thesis]. São Paulo (BR): Faculdade de Saúde Pública da USP; 2007

\begin{abstract}
Background - Health related quality of life and adherence to anti-retroviral therapy among children and adolescents are important questions that have been studied in developed countries, using fundamental questionnaires that were not yet translated or validated in Brazil. Objectives - 1) to translated and to validate the Quality of Life Assessment (QLA) questionnaire, specific to HIV/Aids children and adolescents, and to measure its reliability. 2) to validate a scale of self efficacy expectancy (SE) for antiretroviral therapy among HIV/Aids children and adolescents and to measure its reliability. Methods - The study was conducted in the Centro de Referência e Treinamento em DST/AIDS de São Paulo (CRT/SP). The study was conducted within 90 children and adolescents aging from 6 months old to 20 years old that attended to this health service. The quality of life data were collected by using the Avaliação da Qualidade de Vida (AQV) questionnaire which has 3 versions for 3 specific age levels (6 months old to 4 years old, 5 to 11 years old and 12 to 20 years old) and the SE data were collected using the SE scale for anti-retroviral therapy. The transcultural equivalency of the QLA questionnaire was performed. The internal consistency of the questionnaires was verified using the $\alpha$ Cronbach's coefficient. The confirmatory factorial analysis of the AQV questionnaire and the exploratory analysis of the SE were done. The construct validity was verified by comparing the mean of the scores among Center for Disease Control groups (Mann-Whitney test) for the AQV, and among adherent and non-adherent to the anti-retroviral groups for the SE scale, and also, by the correlation analysis among the AQV scores and the SE scores with clinical markers, and the utilization health services markers. The reliability was verified by the mean comparing test among scores in two moments (paired), by the interclass correlation coefficient $\left(r_{i c c}\right)$ and by the Bland-Altman method. Results -The Portuguese version of the QLA is available as a first product of this work. The AQV questionnaire has showed best internal consistency in the 5 to 11 and 12 to 20 years old age levels. The SE scale internal consistency was good in all age levels and in the total sample. The confirmatory factorial analysis has shown that is possible a reduction of the AQV questionnaire question's numbers. In the 6 months to 4 years old age level, the AQV has discriminated groups only in the physical state domain; significant correlations were obtained with clinical and the utilization health services markers in the domains: Physical Resistance, Social and Role Functioning, Health Services Utilization and Symptoms. The 5 to 11 years old age level has discriminated groups in the General Health Ratings, Physical State, Psychological Well-Being and Symptoms domains. Significant statistic
\end{abstract}


correlations were obtained among the number of visits to the doctor and The Health Care Utilization Domain. In the AQV 12 to 20 years old age levels the discriminate capacity has occurred in the Symptom domain and significant correlations have occurred with clinical markers and health services utilization markers in the domains: General Health Ratings, Social and Role Functioning, Health Care Utilization and Symptoms. The SE scale has reached to discriminate clinical different groups. There was obtained good reliability for the AQV questionnaire and for the AE scale. Conclusions - The AQV questionnaire and the SE scale can be use to measure quality of life and self efficacy in children and adolescents with HIV/Aids, but others studies should be done to improve the AQV questionnaire.

Descriptors: quality of life, children, adolescents, HIV, AIDS, validity studies. 


\section{ÍNDICE}

\section{Pág.}

1. INTRODUÇÃO 23

1.1 A AIDS 23

1.2 A EPIDEMIA DA AIDS NO BRASIL 24

1.3 A TRANSMISSÃO VERTICAL 26

1.4 QUALIDADE DE VIDA E QUALIDADE DE VIDA 29

RELACIONADA À SAÚDE

1.5 QUALIDADE DE VIDA RELACIONADA À SAÚDE EM 31

PACIENTES HIV/AIDS

$\begin{array}{ll}\text { 1.5.1 Adultos } & 31\end{array}$

1.5.2 Crianças e/ou Adolescentes 33

1.6 ADESÃO e AUTO-EFICÁCIA 38

2. OBJETIVOS 42

3. MATERIAL E MÉTODOS

3.1 CASUÍSTICA 43

3.2 METODOLOGIA 45

3.2.1 Instrumentos Utilizados no Trabalho de Coleta dos Dados 47

3.2.1.1 Questionário de Avaliação da Qualidade de Vida 47

(Quality of Life Assessment)

3.2.1.2 Escala de Auto-Eficácia para Seguir Prescrição

Anti-Retroviral (AE)

3.2.1.3 Questionário de Características Sócio-Demográficas 56

3.2.1.4 Questionário de Aderência ao Tratamento Anti- 56

Retroviral 
3.2.1.5 Questionário de Características Clínicas da 57 Criança/Adolescente

3.2.2 Variáveis de Estudo

3.3 TRADUÇÃO 63

3.3.1 Avaliação da Equivalência Conceitual e de Itens 63

3.3.2 Avaliação da Equivalência Semântica 63

3.3.3 Avaliação da Equivalência de Mensuração 64

3.4 ANÁLISE DOS DADOS 65

3.4.1 Caracterização da Amostra 65

3.4.2 Equivalência de Mensuração 65

3.4.2.1 Consistência Interna 65

3.4.2.2 Análise Fatorial $\quad 66$

3.4.2.2.1 Qualidade de Vida 66

3.4.2.2.2 Auto-Eficácia 67

3.4.2.3 Validação $\quad 67$

3.4.2.3.1 Qualidade de Vida $\quad 68$

3.4.2.3.2 Auto-Eficácia $\quad 69$

3.4.2.4 Reprodutibilidade (teste-reteste) $\quad 70$

3.5. PROGRAMAS DE COMPUTADOR (SOFTWARES) 71

3.6 ASPECTOS ÉTICOS , 71

4. RESULTADOS 73

4.1 TRADUÇÃO 73

4.1.1 Avaliação da Equivalência Conceitual e de Itens do 73

Questionário de Qualidade de Vida

4.1.2 Avaliação da Equivalência Semântica $\quad 74$ 
4.2 CARACTERIZAÇÃO DA AMOSTRA 76

4.3 QUESTIONÁRIO DE QUALIDADE DE VIDA 79

4.3.1 Faixa Etária de 6 meses a 4 anos $\quad 79$

4.3.1.1 Avaliação da Equivalência de Mensuração 79

4.3.1.1.1 Consistência Interna 79

4.3.1.1.2 Análise Fatorial Confirmatória $\quad 81$

4.3.1.1.3 Validação $\quad 85$

4.3.1.1.4 Reprodutibilidade $\quad 90$

4.3.2 Faixa etária de 5 a 11 anos $\quad 94$

4.3.2.1 Avaliação da equivalência de mensuração 94

4.3.2.1.1 Consistência interna 94

4.3.2.1.2 Análise Fatorial Confirmatória 96

4.3.2.1.3 Validação 100

4.3.2.1.4 Reprodutibilidade $\quad 104$

$\begin{array}{ll}\text { 4.3.3 Faixa etária de } 12 \text { a } 20 \text { anos } & 108\end{array}$

4.3.3.1 Avaliação da equivalência de mensuração 108

4.3.3.1.1 Consistência interna 108

4.3.3.1.2 Análise Fatorial Confirmatória $\quad 110$

4.3.3.1.3 Validação 114

$\begin{array}{ll}\text { 4.3.2.1.4 Reprodutibilidade } & 118\end{array}$

4.4 ANÁLISE GRÁFICA ENTRE O TESTE E O RETESTE DO 122

QUESTIONÁRIO DE QUALIDADE DE VIDA, COMPARANDO AS TRÊS

FAIXAS ETÁRIAS

4.5 QUESTIONÁRIO DE AUTO-EFICÁCIA 129

4.5.1 Equivalência de mensuração 129

4.5.1.1 Consistência Interna $\quad 129$ 

ESCALA DE AUTO-EFICÁCIA

5.1 ASPECTOS METODOLÓGICOS

5.1.2.1 Faixa etária de 6 meses a 4 anos

5.1.2.2 Faixa etária de 5 a 11 anos

5.1.2.3 Faixa etária de 12 a 20 anos

Anexo 1: Termo de consentimento livre e esclarecido

Anexo 2: Características sócio-demográficas e familiares das crianças/adolescentes

Anexo 3: Questionário de avaliação da qualidade de vida-6, meses a 4 189 anos

Anexo 4: Questionário de avaliação da qualidade de vida-5 a 11 anos 
Anexo 7: Questionário Quality of Life Assessment-5 a 11 anos

Anexo 8: Questionário Quality of Life Assessment-12 a 20 anos

Anexo 9: Questionário de adesão do estudo PERA

Anexo 10: Escala de Auto-Eficácia para seguir prescrição anti-

retroviral

Anexo 11: Maturação sexual -Critérios de Tanner

Anexo 12: Características clínicas da criança/adolescente (dados do

prontuário)

Anexo 13: Fórmulas para o cálculo dos escores

Anexo 14: Aprovação do comitê de ética em pesquisa da Faculdade de

Saúde Pública da Universidade de São Paulo

Anexo 15: Aprovação do comitê de ética em pesquisa do Centro de

Referência e Treinamento em DST/AIDS

Anexo 16: Tabelas com a distribuição das notas para cada questão do questionário de qualidade de vida 


\section{Lista de Tabelas}

Pág.

Tabela 1 - Número e porcentagem de crianças e adolescentes segundo 76 características do respondente. CRT/SP, março 2005.

Tabela 2 - Número e porcentagem de pacientes segundo características sóciodemográficas e clínicas das crianças e adolescentes. CRT/SP, março 2005.

Tabela 3 - Número e porcentagem de crianças e adolescentes segundo características clínicas. CRT/SP, março 2005.

Tabela 4 - Análise descritiva e da consistência interna do questionário de qualidade de vida para a faixa etária de 6 meses a 4 anos. CRT/SP, março 2005.

Tabela 5 - Resultados da análise fatorial confirmatória dos domínios do questionário de qualidade de vida para a faixa etária de 6 meses a 4 anos. CRT/SP, março 2005.

Tabela 6 - Comparação de médias dos domínios da faixa etária de 6 meses a 4 anos em relação às categorias do CDC. CRT/SP, março 2005.

Tabela 7 - Coeficiente de correlação de Spearman (r) entre os escores dos diferentes domínios e a contagem de célula de defesa CD4 e Carga Viral para a faixa etária de 6 meses a 4 anos. CRT/SP, março 2005.

Tabela 8 - Coeficientes de correlação de Spearman (r) entre os escores dos diferentes domínios e marcadores de Utilização dos Serviços de Saúde - noites no hospital e visitas ao médico no último mês para a faixa etária de 6 meses a 4 anos. CRT/SP, março 2005.

Tabela 9 - Comparação teste-reteste entre os escores nos domínios e faixa etária de 6 meses a 4 anos e coeficientes de correlação intraclasse ( $\left.\mathrm{r}_{\text {icc}}\right)$. CRT/SP, março 2005. 
Tabela 10 - Análise descritiva e consistência interna do questionário de qualidade de vida para a faixa etária de 5 a 11 anos. CRT/SP, março 2005.

Tabela 11 - Resultados da análise fatorial confirmatória dos domínios do 98 questionário de qualidade de vida para a faixa etária de 5 a 11 anos. CRT/SP, março 2005.

Tabela 12 - Comparação de médias dos domínios da faixa etária de 5 a 11 anos 100 em relação às categorias do CDC. CRT/SP, março 2005.

Tabela 13 - Coeficiente de correlação de Spearman (r) entre os escores dos 102 diferentes domínios e a contagem de célula de defesa CD4 e Carga Viral para a faixa etária de 5 a 11 anos. CRT/SP, março 2005.

Tabela 14 - Coeficientes de correlação de Spearman (r) entre os escores dos 103 diferentes domínios e marcadores de Utilização dos Serviços de Saúde - noites no hospital e visitas ao médico no último mês para a faixa etária de 5 a 11 anos. CRT/SP, março 2005.

Tabela 15 - Comparação teste-reteste entre os escores nos domínios e faixa 104 etária de 5 a 11 anos e coeficientes de correlação intraclasse $\left(r_{\text {icc}}\right)$. CRT/SP, março 2005.

Tabela 16- Análise descritiva e consistência interna do questionário de 109 qualidade de vida para a faixa etária de 12 a 20 anos. CRT/SP, março 2005.

Tabela 17 - Análise fatorial confirmatória dos domínios do questionário de 112 qualidade de vida para a faixa etária de 12 a 20 anos. CRT/SP, março 2005.

Tabela 18 - Comparação de médias dos domínios da faixa etária de 12 a 20 anos 114 em relação às categorias do CDC. CRT/SP, março 2005. 
Tabela 19 - Coeficiente de correlação de Spearman (r) entre os escores dos 116 diferentes domínios e a contagem de célula de defesa CD4 e Carga Viral para a faixa etária de 12 a 20 anos. CRT/SP, março 2005.

Tabela 20 - Coeficientes de correlação de Spearman (r) entre os escores dos diferentes domínios e marcadores de Utilização dos Serviços de Saúde - noites no hospital e visitas ao médico no último mês para a faixa etária de 12 a 20 anos. CRT/SP, março 2005.

Tabela 21 - Comparação teste-reteste entre os escores nos domínios e faixa 118 etária de 12 a 20 anos e coeficientes de correlação intraclasse ( $\left.r_{\text {icc }}\right)$. CRT/SP, março 2005.

Tabela 22 - Consistência interna do questionário de auto-eficácia para seguir 130 prescrição anti-retroviral segundo faixa etária. CRT/SP, março 2005.

Tabela 23 - Resultados da análise fatorial do escore de auto-eficácia. CRT/SP, 132 março 2005.

Tabela 24 - Comparação de médias dos escores de auto-eficácia em relação aos aderentes e não aderentes ao tratamento anti-retroviral. CRT/SP, março 2005.

Tabela 25 - Coeficiente de correlação de Spearman (r) entre os escores dos diferentes domínios e a contagem de célula de defesa CD4. CRT/SP, março 2005.

Tabela 26 - Comparação teste-reteste entre os escores de auto-eficácia e 138 coeficientes de correlação intraclasse $\left(r_{\text {icc }}\right)$. CRT/SP, março 2005. 


\section{Lista de Quadros}

Pág.

Quadro 1- Instrumentos utilizados para avaliar a qualidade de vida em crianças e adolescentes.

Quadro 2 - Fórmulas para o cálculo dos escores de qualidade de vida.

Quadro 3 - Classificação da maturação sexual para os estágios de Tanner.

Quadro 4 - Características sócio-demográficas e clínicas das crianças/adolescentes $\quad 59$

Quadro 5 - Características do respondente. $\quad 61$

Quadro 6 - Variáveis do questionário de qualidade de vida e da escala de auto- 62 eficácia.

Quadro 7 - Resumo de exemplo das expressões em inglês. 


\section{Lista de Figuras}

Pág.

Figura 1 - Descrição das crianças e adolescentes registrados e da amostra deste estudo.

Figura 2 - Modelo fatorial confirmatório para a qualidade de vida.

Figura 3 - $\quad$ Avaliação Geral da Saúde - Bland Altman (6 meses a 4 anos).

Figura 4 - $\quad$ Resistência Física - Bland Altman (6 meses a 4 anos).

Figura 5 - $\quad$ Estado Físico - Bland Altman (6 meses a 4 anos).

Figura 6 - Atividades Pessoais e Sociais - Bland Altman (6 meses a 4 anos).

Figura 7 - Utilização dos Serviços de Saúde - Bland Altman (6 meses a 4 anos).

Figura 8 - $\quad$ Sintomas ou Sinais - Bland Altman (6 meses a 4 anos).

Figura 9 -

Avaliação Geral da Saúde - Bland Altman (5-11 anos).

Figura 10 - Resistência Física - Bland Altman (5-11 anos). 105

Figura 11 - $\quad$ Estado Físico- Bland Altman (5-11 anos). 106

Figura 12 - $\quad$ Avaliação Psicológica- Bland Altman (5-11 anos). 106

Figura 13 - $\quad$ Atividades Pessoais e Sociais- Bland Altman (5-11 anos). 106

Figura 14 - $\quad$ Utilização dos Serviços de Saúde- Bland Altman (5-11 anos). 107

Figura 15 - $\quad$ Sintomas ou Sinais - Bland Altman (5-11 anos). 107

Figura 16 - $\quad$ Avaliação Geral da Saúde - Bland Altman (12-20 anos). 119

Figura 17 - $\quad$ Estado Físico - Bland Altman (12-20 anos). 119

Figura 18 - $\quad$ Avaliação da Saúde Psicológica - Bland Altman (12-20 anos). 120

Figura 19 - $\quad$ Atividades Pessoais e Sociais - Bland Altman (12-20 anos). 120

Figura 20 - $\quad$ Utilização dos Serviços de Saúde - Bland Altman (12-20 anos). 121

Figura 21 - Sintomas ou Sinais - Bland Altman (12-20 anos). 121

Figura 22 - Médias e respectivos intervalos de 95\% de confiança do domínio 122 Avaliação Geral da Saúde nas duas entrevistas, segundo faixa etária. 
Figura 23 - Diagrama de dispersão entre os valores do domínio de Avaliação Geral da Saúde nas duas entrevistas, segundo faixa etária.

Figura 24 - Médias e respectivos intervalos de $95 \%$ de confiança do domínio Resistência Física nas duas entrevistas, segundo faixa etária.

Figura 25 - Diagrama de dispersão entre os valores do domínio Resistência Física nas duas entrevistas, segundo faixa etária.

Figura 26 - Médias e respectivos intervalos de 95\% de confiança do domínio Estado Físico nas duas entrevistas, segundo faixa etária.

Figura 27 - Diagrama de dispersão entre os valores do domínio Estado Físico nas duas entrevistas, segundo faixa etária.

Figura 28 - Médias e respectivos intervalos de $95 \%$ de confiança do domínio 125 Avaliação da Saúde Psicológica nas duas entrevistas, segundo faixa etária.

Figura 29 - Diagrama de dispersão entre os valores do domínio Avaliação da Saúde Psicologica nas duas entrevistas, segundo faixa etária.

Figura 30 - Médias e respectivos intervalos de 95\% de confiança do domínio 126 Atividades Pessoais e Sociais nas duas entrevistas, segundo faixa etária.

Figura 31 - Diagrama de dispersão entre os valores do domínio Atividades Pessoais 126 e Sociais nas duas entrevistas, segundo faixa etária.

Figura 32 - Médias e respectivos intervalos de $95 \%$ de confiança do domínio Utilização dos Serviços de Saúde nas duas entrevistas, segundo faixa etária.

Figura 33 - Diagrama de dispersão entre os valores do domínio Utilização dos 127 Serviços de Saúde nas duas entrevistas, segundo faixa etária.

Figura 34 - Médias e respectivos intervalos de $95 \%$ de confiança do domínio 128 Sintomas ou Sinais nas duas entrevistas, segundo faixa etária.

Figura 35 - Diagrama de dispersão entre os valores do domínio Sintomas ou Sinais 128 nas duas entrevistas, segundo faixa etária. 
Figura 36 - Escore-1 de auto-eficácia - Bland Altman. $\quad 139$

Figura 37 - Escore-2 de auto-eficácia - Bland Altman. $\quad 139$

Figura 38 - Médias e respectivos intervalos de 95\% de confiança do escore-1 de 140 auto-eficácia nas duas entrevistas, segundo faixa etária.

Figura 39 - Diagrama de dispersão entre os valores do escore-1 de escala de auto- 140 eficácia nas duas entrevistas, segundo faixa etária.

Figura 40 - Médias e respectivos intervalos de 95\% de confiança do escore-2 de 141 auto-eficácia nas duas entrevistas, segundo faixa etária.

Figura 41 - Diagrama de dispersão entre os valores do escore-2 de escala de auto- 141 eficácia nas duas entrevistas, segundo faixa etária. 


\section{INTRODUÇÃO}

\subsection{A AIDS}

A Aids é uma doença resultante de um processo viral que ataca o sistema imunológico e destrói as células que defendem o organismo contra infecções e, quando isto ocorre, a pessoa fica vulnerável a uma variedade de doenças (MINISTÉRIO DA SAÚDE, 2003). Parece ser inexato o seu local de origem (GALLO, 1994; MENDES, 1999), porém há relato de casos isolados de Aids, retrospectivamente diagnosticados, nas décadas de 60 e 70 na América do Norte, América Central, África e Europa (MENDES, 1999). Na década de 1980 a Aids passou a ser epidêmica em regiões da África equatorial, ao mesmo tempo em que ocorriam os primeiros casos no Estados Unidos e no Haiti (GALLO,1994).

Pelo fato da doença ainda não ter sido descrita, a sua disseminação foi rápida. $\mathrm{O}$ vírus causador da doença, uma vez instalado no indivíduo, permite que este infecte outras pessoas não somente dentro de dias ou semanas, como depois de muitos anos (GALLO, 1994). Os fatores que muito contribuíram para a sua disseminação foram o aumento das viagens internacionais, a prática de atividade sexual com muitos parceiros, a freqüente utilização de sangue e produtos sanguíneos para fins médicos e o uso de tóxicos por via intravenosa (GALLO, 1994).

Embora casos isolados com evidências de Aids já tivessem ocorrido, foi no ano de 1981 que o Center for Disease Control and Prevention (CDC) de Atlanta nos Estados Unidos da América (EUA) identificaram, a partir de registros de casos notificados, uma nova epidemia, que viria a ser, segundo BASTOS e col. (2006), a maior de toda a história da humanidade: a epidemia da Síndrome da Imunodeficiência Adquirida (Aids Acquired Immune Deficiency Syndrome).

$\mathrm{Na}$ época, a maioria dos casos registrados havia ocorrido nas cidades de Los Angeles, Nova York e São Francisco, principalmente em pessoas do sexo masculino, homossexuais e usuários de drogas injetáveis. O quadro clínico descrito nos primeiros 
casos era de pneumonia (causada por Pneumocystis carinii) em homossexuais previamente sadios, bem como de outras infecções oportunistas e ainda um tipo raro de câncer de vasos sanguíneos da pele: o sarcoma de Kaposi. Em comum todos os pacientes também apresentavam uma grave depressão da imunidade celular, sem que tivessem feito uso de imunossupressores. A suscetibilidade a infecções oportunistas e o estado de profunda imunodepressão faziam com que os indivíduos acometidos morressem precocemente de doenças infecciosas (ROUQUAYROL e col., 1999; SCLIAR 2002; BASTOS, 2006; BUCHALLA, 2006).

Após o relato de casos da doença entre homossexuais, ela também foi descoberta em hemofílicos e usuários de drogas injetáveis, o que fez com que se suspeitasse da transmissão sanguínea do vírus da doença (FARRELL, 2004; BUCHALLA, 2006). Foram criados, então, critérios para definir o que era mais freqüente em cada área geográfica, segundo seu padrão de transmissão (BUCHALLA, 2006).

O padrão I de transmissão caracteriza-se por contato homossexual e onde a transmissão por uso de drogas injetáveis aumentou. Nesse grupo encontram-se os Estados Unidos, os países da Europa Ocidental, a Austrália e regiões da América Latina. O padrão II caracteriza-se pela predominância da transmissão por contato heterossexual como os países da África Subsaariana e do Caribe. O padrão III aparece nas regiões onde o vírus foi introduzido a partir dos anos 80 e onde a transmissão é heterossexual e está relacionada ao uso de drogas injetáveis. Neste grupo encontram-se países do Leste Europeu, do Oriente Médio, do Norte da África e alguns países da Ásia (BUCHALLA, 2006).

\subsection{A EPIDEMIA DA AIDS NO BRASIL}

De acordo com o Joint United Nations Programme on HIV/Aids (UNAIDS, 2006), 140.000 novos casos de infecção pelo HIV ocorreram na América Latina em 2005, elevando para 1,6 milhão o número de pessoas vivendo com o HIV nessa região. O Brasil, maior país da região, concentra, também, o maior número de pessoas 
infectadas sendo responsável por um terço das pessoas infectadas da América Latina (UNAIDS, 2006). No período de 1980 a 2005 foram notificados, no Brasil, 419.853 casos de Aids, sendo que cerca 67,0\% correspondia a pessoas do sexo masculino. As taxas de incidência segundo o sexo, no ano de 2005 , foram de 21,9 casos por 100.000 habitantes para os homens e 14,2 casos por 100.000 habitantes para as mulheres, enquanto que a taxa total foi de 18,0 casos por 100.000 habitantes (MINISTÉRIO DA SAÚDE, 2006a).

No Brasil, o padrão da infecção pelo vírus da imunodeficiência humana (HIV) e da Síndrome da Imunodeficiência Adquirida (Aids) sofreu mudança profunda desde seu início, na década de 80 . Num primeiro momento, os casos de HIV/Aids estavam relacionados a indivíduos de classe social mais elevada e de maior qualificação profissional, profissionais liberais, artistas, que viajavam para o exterior, principalmente para os EUA, onde teriam se infectado. Assim, os primeiros casos correspondiam aos indivíduos do sexo masculino, homossexuais e bissexuais, que residiam em grandes cidades, principalmente em São Paulo e no Rio de Janeiro. Também os hemofílicos e outras pessoas que recebiam sangue e hemoderivados foram infectados nesta época (SZWARCWALD e col., 2000). No Brasil, a transmissão homossexual correspondia a mais da metade dos casos $(53,1 \%)$ no período de 1980 a $1986,3,4 \%$ dos casos correspondiam ao uso de drogas injetáveis e somente $1,2 \%$ correspondiam à transmissão heterossexual. No período de 1987 a 1994, houve um aumento dos casos decorrentes tanto de transmissão heterossexual quanto pelo uso de drogas, passando a corresponder a $10,5 \%$ e $22,6 \%$ dos casos; em contrapartida houve redução dos casos por transmissão através do uso de sangue e hemoderivados (BUCHALLA, 2006).

Atualmente, no Brasil, mais de $80 \%$ dos casos de Aids ocorrem em indivíduos com 13 anos e mais e estão relacionados a categoria de exposição sexual onde a subcategoria - heterossexual aparece com a maior percentagem de casos da doença $(63,4 \%)$ (MINISTÉRIO DA SAÚDE, 2006b). O crescimento da transmissão heterossexual do HIV nos anos 90, principalmente entre as mulheres em idade fértil, refletiu-se no aumento do número de crianças expostas ao HIV, em conseqüência da 
transmissão vertical (MARQUES e col. 2002; PLUCIENNIK, 2003). No Brasil, o primeiro caso de transmissão vertical foi registrado em 1985 e, desde então, os casos acumulados decorrentes dessa exposição vêm aumentando, apesar das taxas de incidência terem diminuído depois de 1996. Segundo BRITO e col. (2006) a estimativa atual do número de mulheres grávidas infectadas pelo HIV é da ordem de 16.410 mulheres, com idades entre 15 e 34 anos.

\subsection{A TRANSMISSÃO VERTICAL}

A transmissão vertical se caracteriza por ser a principal via de infecção pelo HIV em crianças, sendo que, no Brasil, até dezembro de 2005, foram notificados 12.938 casos, o que corresponde a $81,2 \%$ do total de casos de Aids, em menores de 13 anos (MINISTÉRIO DA SAÚDE, 2006c). Já para o município de São Paulo, no período de 1984 a 2005, foram notificados 1.842 casos de Aids devido à transmissão vertical em menores de 13 anos, o que corresponde a 85,2\% do total dos casos de Aids no município (PROGRAMA MUNICIPAL DE DST/AIDS DE SÃO PAULO, 2007).

A transmissão vertical do HIV para as crianças pode ocorrer em diversos momentos da gestação e parto, pois o HIV pode atravessar a barreira placentária durante estas fases ou ainda ser transmitido pelo leite materno. Segundo BRITO e col. (2006), a maioria $(65,0 \%)$ dos casos de transmissão ocorre durante o trabalho de parto e no parto e os outros $35,0 \%$ dos casos ocorrem intra-útero, nas últimas semanas de gestação. Além disso, o aleitamento materno representa risco adicional de transmissão de 7,0 a $22,0 \%$ (BRITO e col., 2006). Segundo VELOSO e col. (1999), a elevada carga viral materna também é um dos fatores de risco para a transmissão do HIV da mãe para o filho.

As taxas de transmissão vertical variam de um país para outro, sendo que nos EUA e Europa ela é menor que 5,0\%, enquanto que em alguns países do terceiro mundo ela chega a mais de 40,0\% (LWIN e MELVIN, 2001).

Em 1994 foram publicados os resultados do protocolo 076 do Aids Clinical Trial Group (PACTG 076), que mostraram redução significativa na taxa de transmissão 
vertical do HIV (de 25,5\% para 8,3\%), após o uso da zidovudina (AZT) (CONNOR e col., 1994). Esse estudo foi realizado em cinco centros nos EUA e nove centros na França, no período de dezembro de 1989 a fevereiro de 1994 e abrangeu 477 gestantes e 415 crianças que nasceram vivas. Neste estudo ficou comprovada a efetividade da zidovudina na redução da transmissão vertical. $\mathrm{O}$ protocolo do estudo preconizou a administração oral da zidovudina entre a $14^{\mathrm{a}}$ e $34^{\mathrm{a}}$ semanas de gestação, a administração endovenosa de zidovudina (AZT) durante o parto e a zidovudina xarope à criança até seis semanas após seu nascimento. Baseado nestes achados, o Center for Disease Control and Prevention (CDC) publicou a recomendação para o uso do AZT, pelas mulheres grávidas e infectadas pelo HIV, durante o segundo e o terceiro trimestre de gestação e durante o parto. Nas crianças o uso do AZT é recomendado durante as seis primeiras semanas de vida (CDC, 1994).

O MS, após a divulgação dos resultados do protocolo 076, estabeleceu norma, em 1995, sobre prevenção da transmissão vertical baseada no referido protocolo e a definiu como uma das prioridades para o Programa Nacional de DST e Aids. Entretanto as recomendações desta norma somente foram implementadas nos manuais de condutas para tratamento de adultos e crianças infectadas pelo HIV em 1997 (MARQUES e col. 2002; BRITO e col., 2006). As ações de prevenção compreendem o aconselhamento e testagem para o HIV no pré-natal, a administração do zidovudina para as gestantes HIV e seus recém-nascidos e a substituição do aleitamento materno (MINISTÉRIO DA SAÚDE, 2006d).

As ações de prevenção em vários países vêm contribuindo para uma diminuição significativa do número de casos de Aids relacionados com a transmissão vertical. No Brasil, a taxa de transmissão vertical teve uma redução para o País como um todo: de 16\% em 1997 a 7,8 \% em 2001 para o estado de São Paulo (TESS e col., 1998) e 3,7 \% em 2002, com variações regionais (BRITO e col., 2006, DOURADO e col., 2006). No município de São Paulo, observa-se que a taxa de transmissão vertical que era de $8,5 \%$ no ano 2000 passou para aproximadamente 2,1\% em 2004 (PROGRAMA MUNICIPAL DE DST/AIDS DE SÃO PAULO, 2007). 
As crianças nascidas de portadoras do HIV, mesmo com as ações de prevenção preconizadas pelo MS estão expostas ao HIV e podem ou não desenvolver a infecção.

Ao nascimento, praticamente todas as crianças apresentam anticorpos anti-HIV séricos devido à passagem de anticorpos maternos pela placenta. Essa indefinição diagnóstica pode persistir até os 15 meses de idade, época em que se espera que os anticorpos maternos tenham sido substituídos, ou não, pelos da criança (ORTIGÃO, 1995). Como profilaxia, os recém-nascidos devem receber solução oral de AZT imediatamente após o nascimento (nas duas primeiras horas de vida) ou nas primeiras oito horas de vida e a administração oral do AZT deve ser mantida durante as seis primeiras semanas de vida (42 dias). As crianças expostas devem ser acompanhadas durante os dois primeiros anos de vida, sendo que o acompanhamento deve ser mensal nos primeiros 6 meses de vida e, no mínimo, trimestral a partir do segundo semestre de vida. Solicita-se, também, registrar o peso e altura das crianças para avaliação do crescimento e desenvolvimento, pois crianças infectadas podem, já nos primeiros meses de vida, apresentar dificuldade de ganho de peso (MINISTÉRIO DA SAÚDE, 2004).

MATIDA e col. (2004) realizaram um estudo de coorte retrospectiva que teve por objetivo verificar a tendência da sobrevida de 914 pacientes brasileiros com Aids menores de 13 anos, infectados por transmissão vertical, com diagnóstico entre 1983 e 1998. Os autores observaram que o tempo mediano de sobrevida para crianças diagnosticadas antes de 1988 era de 20 meses, tempo esse que teve um aumento progressivo até chegar aos 50 meses no período de 1993 a 1994. Também foi observado que $75 \%$ das crianças diagnosticadas entre 1997 e 1998 continuaram vivas após 4 anos de seguimento. Vale considerar que mais de $75 \%$ das crianças estavam recebendo algum tipo de terapia anti-retroviral.

Assim, pelo exposto, observa-se que os medicamentos anti-retrovirais e a sua disponibilização pelo MS têm retardado o aparecimento de sintomas e prolongado a sobrevida das crianças que vivem com HIV/Aids, transformando a infecção pelo HIV em uma doença crônica, permitindo que muitas das crianças infectadas cheguem a adolescência (PLUCIENNIK, 2003). 
A mudança no padrão de sobrevida das crianças/adolescentes aliada à necessidade de se compreender melhor sua condição de saúde de uma maneira multidimensional e dentro de seu estágio de desenvolvimento, tem criado a oportunidade de se desenvolver formas de avaliar a qualidade de vida dessas crianças/adolescentes.

\subsection{QUALIDADE DE VIDA $\quad \mathrm{E}$ QUALIDADE $\quad$ DE $\quad$ VIDA RELACIONADA À SAÚDE}

Segundo MINAYO e col. (2000), o termo qualidade de vida é uma representação social criada a partir de parâmetros subjetivos (não materiais) - bem-estar, felicidade, amor, liberdade, solidariedade, inserção social, prazer, realização pessoal - e também objetivos (materiais) como a satisfação das necessidades básicas (alimentação, acesso a água potável, habitação, trabalho, educação, saúde e lazer), bem como parâmetros determinados pelo grau de desenvolvimento econômico e social de determinada sociedade (conforto, bem-estar, realização individual e coletiva). A qualidade de vida também está relacionada ao campo da democracia, do desenvolvimento dos direitos humanos e sociais que é o próprio exercício da cidadania. Os autores do estudo destacam ainda, que o desemprego, a exclusão social e a violência são a negação da qualidade de vida.

A Organização Mundial de Saúde (OMS) define, de maneira genérica, o termo segundo o qual a qualidade de vida é a percepção do indivíduo de sua posição na vida no contexto da cultura e sistema de valores nos quais ele vive e em relação aos seus objetivos, expectativas, padrões e preocupações (THE WHOQOL GROUP, 1994). Essa conceituação abarca o caráter subjetivo e multidimensional da qualidade de vida.

A qualidade de vida relacionada à saúde também é um conceito multidimensional que inclui aspectos sociais, estados fisiológico e emocional, capacidade cognitiva e da satisfação geral com a vida (FARQUHAR, 1995; MCDONNELL e col., 2000) e avalia a percepção do indivíduo sobre os sintomas ou incapacidades ocasionados por determinada doença. 
$\mathrm{Na}$ área da saúde, a conceituação de qualidade de vida tem sido descrita segundo duas tendências (SEIDL, 2001). Uma envolve uma definição genérica do termo sendo que os estudos que avaliam qualidade de vida, segundo essa acepção, podem ser realizados tanto com pessoas saudáveis como com pessoas doentes. A outra tendência diz respeito à qualidade de vida relacionada à saúde especificamente (health-related quality of life), que visa detectar os aspectos mais diretamente relacionados à doenças ou enfermidades e aqueles relacionados às intervenções de saúde.

Ainda sob a perspectiva da área da saúde, a qualidade de vida ou, ainda, a melhoria da qualidade de vida passou a ser um dos resultados esperados, tanto das práticas assistenciais quanto das políticas públicas nos campos da promoção da saúde e da prevenção de doenças. A qualidade de vida pode ser um indicador do impacto físico e psicossocial que as doenças acarretam nos indivíduos acometidos e, dessa forma, permite um melhor conhecimento do paciente e de sua adaptação a alguma situação ou condição de saúde (SEIDL e ZANNON, 2004).

Os instrumentos padronizados que mensuram a qualidade de vida são questionários que contemplam os conceitos envolvidos na sua definição - estado físico, sintomas, social, estado emocional, função cognitiva e o sentimento em relação à saúde. São utilizadas basicamente três estratégias para essa avaliação: a primeira envolve o uso de medidas genéricas de qualidade de vida que permitem a comparação entre populações, doenças, condições ou investigações. A segunda diz respeito a medidas específicas para a doença sob estudo, que visam detectar mudanças clínicas importantes (efeitos do tratamento). A terceira trata-se de uma aproximação modular onde vários aspectos da qualidade de vida de outros instrumentos são utilizados para compor um novo instrumento. Recomenda-se que os questionários sejam auto-respondidos (MCSWEENY e CREER, 1995).

Segundo WU (2000), a avaliação da qualidade de vida relacionada à saúde pode ser utilizada para responder questões referentes ao cuidado clínico de pacientes, a fim de otimizar a qualidade de vida e, conseqüentemente, melhorar a aderência das pessoas ao tratamento. Também pode ser útil para auxiliar políticas públicas de saúde que 
beneficiem grupos vulneráveis (mulheres, crianças, famílias, indivíduos com baixa escolaridade, pessoas dependentes de álcool e drogas), levando em conta as incapacidades dessas pessoas. $\mathrm{O}$ autor também menciona a importância da qualidade de vida na avaliação de programas e serviços de saúde.

\subsection{QUALIDADE DE VIDA RELACIONADA À SAÚDE EM PACIENTES HIV/AIDS}

\subsubsection{Adultos}

Muitas pesquisas já foram conduzidas com o intuito de se avaliar a qualidade de vida em adultos que vivem com HIV/Aids. Segundo WU (2000), os primeiros estudos sobre esta temática coincidiram com o lançamento, em 1986, AZT, sendo que a avaliação da qualidade de vida tinha como propósito dar suporte às decisões clínicas e identificar diferenças entre tratamentos nos ensaios clínicos.

$O$ instrumento mais comumente utilizado em pesquisa sobre HIV/Aids em adultos é o MOS-HIV que é um instrumento específico para este agravo e tem sido utilizado em estudos observacionais e ensaios clínicos (WU e col., 1991; WU e col., 1993; BURGESS e col., 1993; REVICKI e col., 1995; COPFER e col., 1996; WU e col., 1997a; WU e col., 1997b; WEINFURT e col., 2000; BUCCIARDINI e col., 2000).

De acordo com WU e col. (1997a), o primeiro instrumento utilizado para avaliação da qualidade de vida em HIV/Aids foi o MOS-HIV, derivado do Medical Outcome Study Short Form 20 (SF-20). Inicialmente, foram incluídos, no SF-20, conceitos relevantes ao HIV/Aids como energia, preocupações com a saúde e função cognitiva, resultando, assim, num questionário com 30 itens. Versões posteriores incorporaram ou alteraram alguns itens resultando num questionário que, atualmente, possui 35 itens e dez dimensões (percepção geral de saúde, dor, função física, social, saúde mental, atividades diárias, energia/fadiga, função cognitiva, preocupações com a saúde e qualidade de vida). O instrumento Medical Outcome Study já foi utilizado em 
estudos no Brasil e a autorização para seu uso deve ser pedida diretamente para os autores americanos.

Há outros questionários utilizados tanto em estudos observacionais, como em ensaios clínicos sobre HIV/Aids, que levam em conta aspectos singulares da infecção como sintomas, mudanças físicas, problemas de ordem cognitiva/emocional como incerteza, falta de controle e aspectos da vida diária, e também do tratamento (MCSEWEENY e CREER 1995; BERZON e col. 1997). Recentemente a OMS testou um questionário específico para avaliar qualidade de vida em pacientes portadores de HIV/Aids, criado a partir do WHOQOL. Este é um instrumento genérico para avaliar qualidade de vida onde foram adicionados domínios que englobam sintomas do HIV, inclusão social, morte, culpa e medo do futuro (WHOQOL HIV GROUP, 2004).

Especificamente para o Brasil, cinco estudos analisaram a qualidade de vida em adultos com HIV/Aids.

SEIDL (2001) avaliou a qualidade de vida de 241 adultos assintomáticos e sintomáticos/doentes de Aids em dois serviços públicos de Brasília (DF) por meio do WHOQOL-100. Concluiu que as variáveis psicossociais são importantes para predizer a qualidade de vida, enquanto que a condição clínica tem um fraco poder de predição, o que pode ser atribuído, segundo a autora, ao tratamento anti-retroviral.

No estudo realizado por SANTOS (2003) foi avaliada a qualidade de vida de 365 adultos vivendo com HIV/Aids, na Casa da Aids em São Paulo, utilizando o WHOQOLbref. Concluiu-se que, as mulheres, os pacientes de cor preta e parda, aqueles com menor renda, aqueles com número de células CD4+ abaixo de $200 / \mathrm{mm}^{3}$, bem como aqueles com indicação ou seguimento psiquiátrico, tiveram os piores escores de qualidade de vida.

Um outro estudo foi realizado por NETO e SICILIANO (2000) que avaliaram a qualidade de vida por meio da escala de qualidade de vida denominada Karnofsky. Analisaram 36 pacientes com Aids, que nunca haviam sido tratados, concluindo que os tratamentos com AZT, 3TC e ritonavir melhoraram a qualidade de vida para os 
pacientes em termos dos aspectos psicossociais e das condições gerais, durante os 6 meses de tratamento.

O estudo proposto por GALVÃO e col. (2004) avaliou a qualidade de vida entre mulheres portadoras de HIV/Aids por meio do instrumento específico HAT-QOL, em um ambulatório especializado em HIV/Aids, de uma universidade pública do Estado de São Paulo. Foram estudadas 73 mulheres com HIV/Aids e foi verificado que, além da doença, essas mulheres tinham uma situação sócio-econômica precária que interferiu negativamente nos seguintes domínios, "preocupações financeiras”, “ preocupação com o sigilo sobre a infecção” , “ atividades sexuais” e preocupações com a saúde”. Os autores concluíram que a escala foi adequada para a população de mulheres portadoras de HIV/Aids.

TOSTES e col. (2004) avaliaram o impacto de fatores clínicos, demográficos e psiquiátricos na qualidade de vida relacionada à saúde de 76 mulheres com infecção pelo HIV, em dois centros de referência do Brasil. Foi utilizado o questionário genérico de avaliação da qualidade de vida, o SF-36. Concluíram que quanto maior a presença de sintomas mentais, pior é a qualidade de vida relacionada à saúde nas mulheres estudadas.

\subsubsection{Crianças e/ou Adolescentes}

Quando se pesquisa o termo qualidade de vida em crianças e/ou adolescentes com HIV/AIDS, verifica-se que os questionários abordam temas bem diversos. Para citar alguns exemplos, existem estudos que abordam a qualidade de vida com enfoque sobre o crescimento de crianças nascidas de mães HIV (NEWELL e col., 2003), sobre a nutrição (BUTENSKY e col., 2001), sobre implante coclear (O'NEILL e col., 2000), sobre dor (HIRSCHFELD e col., 1996; GAUGHAN e col., 2002), sobre o impacto psicológico em crianças órfãs (SENGENDO e NAMBI, 1997), sobre questões comportamentais antes e depois do uso da terapia com o AZT (WOLTERS e col., 1994), 
e também sob a ótica de marcadores biológicos da infecção pelo HIV e da terapia antiretroviral (ROTTA e col., 2003).

Segundo DROTAR (1998), existe uma necessidade de avaliar a percepção das crianças e de seus familiares com relação aos benefícios do tratamento a que estão sendo submetidas, que vai além dos resultados físicos e clínicos (sintomas, mudanças fisiológicas, peso e altura). A avaliação da qualidade de vida em crianças com HIV/Aids é importante, pois permite obter informações sobre o estado de saúde geral da criança, facilita a identificação de crianças com diferenciados níveis de morbidade e, também, possibilita uma melhora no processo de decisão clínica, uma vez que se tem a percepção da criança sobre sua experiência com a doença e tratamento.

$O$ instrumento para avaliação da qualidade de vida deve abranger questões específicas da doença ou do tratamento e deve ser sensível a mudanças na condição de saúde ou no tratamento da criança (DROTAR e LEVI, 1998). Além disso, há outras questões, como o fato da família ou pais estarem muito doentes para cuidar das crianças, a falta de apoio na escola e dos pares devido ao estigma da doença, bem como a descoberta do diagnóstico (McCARDLE e col., 1995).

Outros autores, como LAUFER e SCOTT (2000) relatam que a qualidade de vida também é muito importante quando se está estudando pacientes crônicos, especialmente crianças no último estágio da infecção pelo HIV. Eles comentam que a qualidade de vida faz parte do cuidado paliativo, pois foca os aspectos físicos, psicológicos e sociais inerentes às doenças fatais.

A avaliação da qualidade de vida em crianças/adolescentes fica comprometida se for utilizado somente um único questionário para todas as idades, da infância até a adolescência, pois o desenvolvimento muda de acordo com a idade. Assim, os questionários têm que levar em conta as diversas fases de desenvolvimento da criança (GORTMAKER e col., 1998; EISER e MORSE, 2001). Como exemplo pode-se citar o questionário Quality Life Assessment, desenvolvido por GORTMAKER e col. (1998), no domínio Avaliação Geral da Saúde, são incorporadas questões que levam em conta as diferenças das faixas etárias. Para a faixa de 6 meses a 4 anos é perguntado como a 
criança tem se sentido, em média, nos últimos 3 meses, de uma maneira geral, física e emocionalmente. Na faixa de 5 a 11 anos, além dos aspectos anteriores, acrescenta-se um quarto item: acerca de sua atividade em sala de aula. Na faixa de 12 a 20 anos, o item 4 é mais abrangente, pois pergunta em relação às suas atividades diárias como a atividade em sala de aula, emprego ou trabalho doméstico.

Uma outra questão ao avaliar crianças é sobre "a quem perguntar" (GORTMAKER e col., 1998). Embora as crianças possam responder a partir de uma certa idade, os pais/cuidadores são os que melhor podem informar, pois as crianças podem ser muito jovens ou estarem muito doentes para responder. Além disso, EISER e MORSE (2001) colocam que as crianças não podem se auto-avaliar por falta de desenvolvimento linguístico e cognitivo. Recomenda-se, também, que os pais/cuidadores respondam para as crianças de 6 meses a 4 anos e também para as de 5 a 11 anos (GORTMAKER e col., 1998; DROTAR e LEVI, 1998).

O Quadro 1 sintetiza os instrumentos para avaliar a qualidade de vida em crianças/adolescentes com HIV/Aids que foram encontrados na literatura. Vale ressaltar que nenhum desses instrumentos foi utilizado no Brasil e tampouco validado para estudos com essa população neste país.

NICOLAS e col. (1996) avaliaram a qualidade de vida relacionada à saúde de crianças e adolescentes acima de 4 anos. As crianças responderam o AUQEI que é um questionário de qualidade de vida com 27 questões e que foi adaptado para crianças com HIV/Aids. Além disso, foram aplicados questionários, abordando outros aspectos, que foram respondidos pelos médicos, equipes de enfermagem e pais. $\mathrm{O}$ que foi preenchido pelo médico avaliou o crescimento, desenvolvimento e saúde da criança. $O$ que foi preenchido pela equipe de enfermagem (33 questões) e pais (71 questões) avaliou o desconforto ou o grau de satisfação em relação a vários aspectos da vida da criança e de seus pais, e foi complementado por um questionário que avaliou as condições psicológicas e de comportamento das crianças e de seus pais.

No estudo realizado por GORTMAKER e col. (1998) sobre qualidade de vida relacionada à saúde em crianças e adolescentes de 0 a 11 anos com HIV/Aids, foi 
desenvolvido um questionário modular específico para esse grupo, denominado GHAC (General Health Assessment for Children), em que a composição de cada domínio foi feita a partir de outros questionários sobre qualidade de vida. Para os pacientes de 12 a 20 anos foi utilizado um questionário de adultos. Foram os pais/cuidadores que responderam para os três grupos etários. Segundo os autores, os domínios mais importantes para HIV/Aids são os de sintomas, o social e psicológico. Esse instrumento teve boa consistência interna e conseguiu discriminar as crianças e adolescentes que estão infectados pelo HIV dos que têm Aids e sua aplicação levou em torno de 20 minutos. Esse instrumento está sendo utilizado em um estudo, que está sendo conduzido nos EUA (www.clinicaltrials.gov/ct/show), sobre qualidade de vida de pacientes de 10 meses a 25 anos. Após contato com os autores, esse instrumento mostrou ser o mesmo que está disponibilizado no site www.fstrf.org e intitulado Quality of life assessment que tem três versões (Quadro 1), cada uma delas específica para uma faixa etária. Essas versões diferem entre si não só nos domínios, como nas questões que os compõem. Os autores aprovaram a utilização do instrumento para sua validação no Brasil. 
Quadro 1: Instrumentos utilizados para avaliar a qualidade de vida em crianças e adolescentes.

\begin{tabular}{|c|c|c|}
\hline Instrumento/Faixa etária & Domínios & Validação \\
\hline AUQEI: acima de 4 anos & $\begin{array}{l}\text { Autonomia; atividades de lazer; } \\
\text { funções (sono, alimentação, } \\
\text { saúde e escola); relações } \\
\text { familiares. }\end{array}$ & $\begin{array}{l}\text { Nicolas e col. } \\
\text { (1996). }\end{array}$ \\
\hline $\begin{array}{l}\text { Quality of life assessment }= \\
\text { GHAC: } 6 \text { meses a } 4 \text { anos }\end{array}$ & $\begin{array}{l}\text { Estado de saúde geral; estado } \\
\text { funcional; função social e } \\
\text { atividades; utilização de } \\
\text { cuidado médico; sintomas. }\end{array}$ & $\begin{array}{l}\text { www.fstrf.org } \\
\text { Gortmaker e } \\
\text { col. (1998). }\end{array}$ \\
\hline $\begin{array}{l}\text { Quality of life assessment = } \\
\text { GHAC: } 5 \text { a } 11 \text { anos }\end{array}$ & $\begin{array}{l}\text { Estado de saúde geral; função } \\
\text { física; bem estar psicológico; } \\
\text { função social e atividades; } \\
\text { utilização de cuidado médico; } \\
\text { sintomas. }\end{array}$ & $\begin{array}{l}\text { www.fstrf.org } \\
\text { Gortmaker e } \\
\text { col. (1998). }\end{array}$ \\
\hline $\begin{array}{l}\text { Quality of life assessment = } \\
\text { GHAC: } 12 \text { a } 20 \text { anos }\end{array}$ & $\begin{array}{l}\text { Estado de saúde geral; função } \\
\text { física; bem estar psicológico; } \\
\text { função social e atividades; } \\
\text { utilização de cuidado médico; } \\
\text { sintomas. }\end{array}$ & 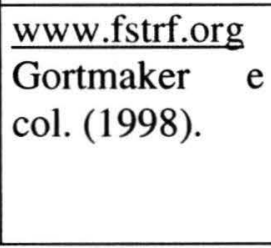 \\
\hline
\end{tabular}

Outros três estudos foram realizados, nos EUA, utilizando o Quality of life assessment.

O primeiro avalia a prevalência de dor em crianças e adolescentes com HIV/Aids (GAUGHAN e col., 2002). O questionário foi aplicado aos cuidadores de 985 crianças e adolescentes que participavam de um estudo de coorte prospectiva (Pediatric Late Outcomes Study - PACTG 219), no período de 1 de janeiro de 1996 até 31 de dezembro de 1999. Para verificar a prevalência de dor foram utilizadas 7 questões do domínio de Sintomas ou Sinais do questionário de qualidade de vida. Como resultados obteve-se que a prevalência de dor manteve-se constante ao longo do período (em torno de $20 \%$ ) sendo que os fatores associados ao aumento do risco de dor foram menores níveis de células de defesa CD4, sexo feminino e relato do diagnóstico de HIV/Aids. Além disso, a dor também esteve associada a um aumento do risco de morte.

Em um outro estudo, STORM e col. (2005) comparam a qualidade de vida de crianças e adolescentes com HIV/Aids entre grupos de tratamento anti-retroviral que 
utilizam os Inibidores de Protease (IP). Participaram desse estudo transversal 940 crianças/adolescentes de 5 a 18 anos que já estavam envolvidas no estudo de coorte do PACTG 219. Concluiu-se que a qualidade de vida das crianças que utilizam IP difere pouco daquelas que não utilizam IP, apesar de indicadores do estágio mais avançado da doença. Foram encontradas diferenças estatisticamente significativas $(p<0,05)$ nos domínios de Atividades Pessoais e Sociais e Sintomas.

No terceiro estudo, LEE e col. (2006) compararam a qualidade de vida entre crianças infectadas e crianças não infectadas pelo HIV, além de avaliarem o impacto de diferentes esquemas de tratamento anti-retroviral nas crianças infectadas. A qualidade de vida foi avaliada nas três faixas etárias -6 meses a 4 anos, 5 a 11 anos e 12 a 20 anos de idade. Na faixa etária de 6 meses a 4 anos houve diferença estatisticamente significativa nas médias dos escores de estado funcional entre infectados e não infectados; na faixa de 5 a 11 anos houve diferença estatisticamente significativa nas médias dos escores de Avaliação Geral da Saúde, Resistência Física, Estado Físico e Atividades Pessoais e Sociais. Crianças e adolescentes de 5 a 20 anos infectados e que não estavam tomando medicamentos anti-retrovirais tiveram piores percepções de saúde quando comparados com aqueles que estavam tomando anti-retrovirais. Também foi constatado que os adolescentes que não estavam tomando medicamentos anti-retrovirais tiveram os piores Sinais/Sintomas quando comparados com aqueles que estavam tomando.

\subsection{ADESÃO e AUTO-EFICÁCIA}

Um dos pontos importantes quando se fala de qualidade de vida em pacientes HIV/Aids é sua relação com a adesão ao tratamento anti-retroviral. A terapia antiretroviral de alta potência, ou o termo em inglês Highly active combination antiretroviral therapy (HAART), tem se mostrado efetiva para a redução da replicação do HIV e, assim, previne infecções oportunistas, reduz a mortalidade e proporciona uma melhora na sobrevida e na qualidade de vida de adultos, adolescentes e crianças infectados pelo HIV. Entretanto, muitos fatores podem afetar o processo de supressão da 
replicação viral, incluindo a baixa potência de uma das drogas da combinação, resistência viral, uso de drogas ilícitas e inadequada aderência ao tratamento ou terapia (LEITE e col., 2002; DYKE e col., 2002; SHAH, 2007). Segundo STARACE e col. (2006), o principal fator que contribui para o sucesso da terapia é a alta adesão (acima de 95\%) ao tratamento. O uso irregular, doses insuficientes ou o não seguimento de rotinas para a absorção podem aumentar o risco de falência virológica e resistência viral (LEITE e col., 2002). Assim sendo, SHAH (2007) coloca que a adesão representa um grande desafio para as crianças em tratamento, para seus pais/cuidadores, bem como para o médico.

Adesão à medicação pode ser definida, segundo SHAH (2007), como a capacidade do paciente seguir as prescrições de medicamentos oferecidas pelo médico. Entretanto, o autor coloca que, no contexto da terapia antiretroviral, a adesão pode ser definida como um posicionamento da pessoa em consonância com as recomendações médicas, não somente no que se refere à tomada de medicamentos prescritos, mas também, com relação à dieta especificada e possíveis mudanças no seu estilo de vida. No tratamento de pacientes com HIV/Aids é essencial que a adesão ao tratamento seja superior a 95\%, para supressão da replicação viral e para evitar resistência do vírus. No caso de crianças, a adesão depende tanto do comportamento dos pais/cuidadores, bem como da própria criança, em acatar as recomendações feitas pelo médico.

Os fatores que podem influenciar tanto positivamente como negativamente a adesão podem ser divididos em três grupos (SHAH, 2007). Um primeiro grupo diz respeito ao fatores referentes a família/pais/cuidadores (ansiedade, depressão, uso de substância ativa (droga), presença de infecção pelo HIV em outro membro da família, medo da descoberta da situação de HIV positivo, problemas na família) e fatores ligados ao paciente (idade da criança/adolescente, recusa ao tratamento, conhecimento da situação de infectado pelo HIV, mudanças clínicas e mudanças no estado de saúdel melhora ou piora). $\mathrm{O}$ segundo grupo diz respeito aos fatores relacionados à medicação como gosto, sabor, tamanho das pílulas, disponibilidade de fórmulas líquidas, especificações de armazenagem (refrigerador para as formulações líquidas), efeitos 
adversos, administração diária, freqüência da dose e restrição dietética. O terceiro grupo diz respeito aos fatores relacionados ao serviço de saúde como a disponibilidade e o acesso aos medicamentos, facilidade para diagnóstico e tratamento, custo dos medicamentos, presença de profissionais com experiência em HIV pediátrico, suporte social, econômico e psicológico para os pacientes e seus cuidadores, no caso de crianças e adolescentes. Além destes, LEITE e col. (2002) acrescentam que esquecimento, distração, interrupção da rotina, ou o fato de estarem fora de casa ou dormindo são referidos, pelos pacientes, como razões para o não uso da medicação.

LEITE e col. (2002) desenvolveram uma escala de auto-eficácia para adesão ao tratamento anti-retroviral para pacientes adultos com Aids. Esta escala é baseada na teoria cognitivo-social de BANDURA (1977) que tem sido usada para compreender comportamentos de proteção à saúde. A auto-eficácia é o julgamento do sujeito sobre sua habilidade para desempenhar com sucesso um padrão específico de comportamento. Dessa forma, a expectativa de auto-eficácia para tomar medicamentos conforme a prescrição, é a convicção na capacidade pessoal de controlar as circunstâncias que possam dificultar o seguimento regular da prescrição e realizar com sucesso tal comportamento. Participaram do estudo de LEITE e col. (2002), 93 adultos, de ambos os sexos, com HIV/Aids e indicação de tratamento anti-retroviral.

A escala de expectativa de auto-eficácia poderia ser uma medida fácil e rápida de se avaliar adesão ao uso de medicamentos em crianças e adolescentes com HIV/Aids. No entanto, até o presente momento, não há instrumento específico para avaliar adesão em crianças ou adolescentes vivendo com HIV/Aids uma vez que a escala foi validada apenas em adultos com HIV/Aids.

A importância de se estudar adesão em um contexto da qualidade de vida está relacionada a fato de que a adesão pode ser um dos fatores que pode interferir na qualidade de vida das crianças e adolescentes com HIV/Aids. Embora não seja o escopo deste estudo verificar os fatores associados à qualidade de vida, fica evidente a necessidade de se validar um instrumento que possa avaliar a adesão para que em estudos futuros este ferramental esteja disponível. 
Pelo exposto, observa-se que questões importantes como qualidade de vida relacionada a saúde e adesão ao uso de medicamentos em crianças têm sido estudadas em países desenvolvidos, utilizando, fundamentalmente, questionários que ainda não foram traduzidos e/ou validados aqui no Brasil. E esta é a proposta deste trabalho.

O local escolhido para realização do estudo foi o Centro de Referência e Treinamento em DST/Aids de São Paulo (CRT/SP). Sabe-se que o município de São Paulo dispõe de outros serviços que realizam o mesmo tipo de atendimento, porém, por questões operacionais, como facilidade de acesso, número de crianças matriculadas e o interesse do serviço na realização da pesquisa, o CRT/SP foi o local escolhido. 


\section{OBJETIVOS}

2.1. Traduzir e validar o questionário Quality of Life Assessment que é específico para crianças e adolescentes com HIV/Aids e avaliar a sua reprodutibilidade;

2.2. Validar um questionário sobre expectativa de auto-eficácia para seguir prescrição anti-retroviral em crianças e adolescentes com HIV/Aids e avaliar a sua reprodutibilidade. 


\section{MATERIAL E MÉTODOS}

\subsection{CASUÍSTICA}

O estudo foi conduzido no período de 27 de março a 20 de agosto de 2005, no Hospital Dia do Centro de Referência e Treinamento em DST/Aids de São Paulo (CRT/SP). Participaram do estudo crianças e adolescentes de 6 meses a 20 anos que passaram em consulta de rotina pelo serviço.

O tamanho da amostra foi calculado baseado nos resultados do estudo de GORTMAKER e col. (1998). Nesse estudo, para crianças com Aids, o coeficiente alpha de Cronbach variou de 0,68 a 0,94 . Assumindo $\alpha=5 \%$ e $\beta=10 \%$, estimou-se que seriam necessárias 25 crianças com HIV/Aids para a fase de validação. Como o questionário de qualidade de vida contempla 3 faixas etárias, estimou-se que seriam necessárias, no mínimo, 25 crianças para cada faixa etária.

O estudo de GORTMAKER e col. (1998) somente validou o questionário de qualidade de vida para a faixa etária de 5 a 11 anos. Os resultados da consistência interna dos questionários para as outras duas faixas etárias foram apresentados no estudo de LEE e col. (2006). Neste trabalho optou-se por trabalhar com as três faixas etárias, mesmo estando ciente de que na faixa etária de 6 meses a 4 anos se poderia encontrar mais crianças expostas do que infectadas e/ou doentes, o que poderia diminuir o poder dos testes estatísticos. No entanto, considerou-se que seria importante fazer esta análise para se ter uma mínima idéia da adequação dos instrumentos para esta faixa etária, ao invés de simplesmente utilizá-los em outras pesquisas ou excluir este grupo etário das análises de qualidade de vida, que é o que tem sido feito em outras pesquisas já citadas (GAUGHAN e col., 2002; STORM e col., 2005; LEE e col., 2006).

$\mathrm{Na}$ época do campo, o Hospital Dia do CRT/SP tinha o registro de 134 crianças e adolescentes na sua base de dados.

A Figura 1 descreve os passos para se chegar à amostra deste estudo. Dos 134 pacientes registrados no CRT, conseguiu-se contatar $96(71,6 \%)$, pois 3 adolescentes 
$(2,2 \%)$ vieram na consulta desacompanhados, 12 crianças $(9,0 \%)$ faltaram ao serviço e 23 crianças $(17,2 \%)$ não tinham previsão para consulta, pois mudaram-se para outras cidades.

Dos 96 pais/responsáveis que foram convidados a participar da pesquisa, poucos se recusaram $(6,3 \%)$ a participar, sendo 5 mães de crianças na faixa de 6 meses a 4 anos que estavam sem tempo e 1 adolescente acompanhada da tia não quis participar por não gostar de pesquisas.

Sendo assim, dos 134 pacientes registrados, conseguiu-se entrevistar 90, o que corresponde a $67,2 \%$ da população de estudo.

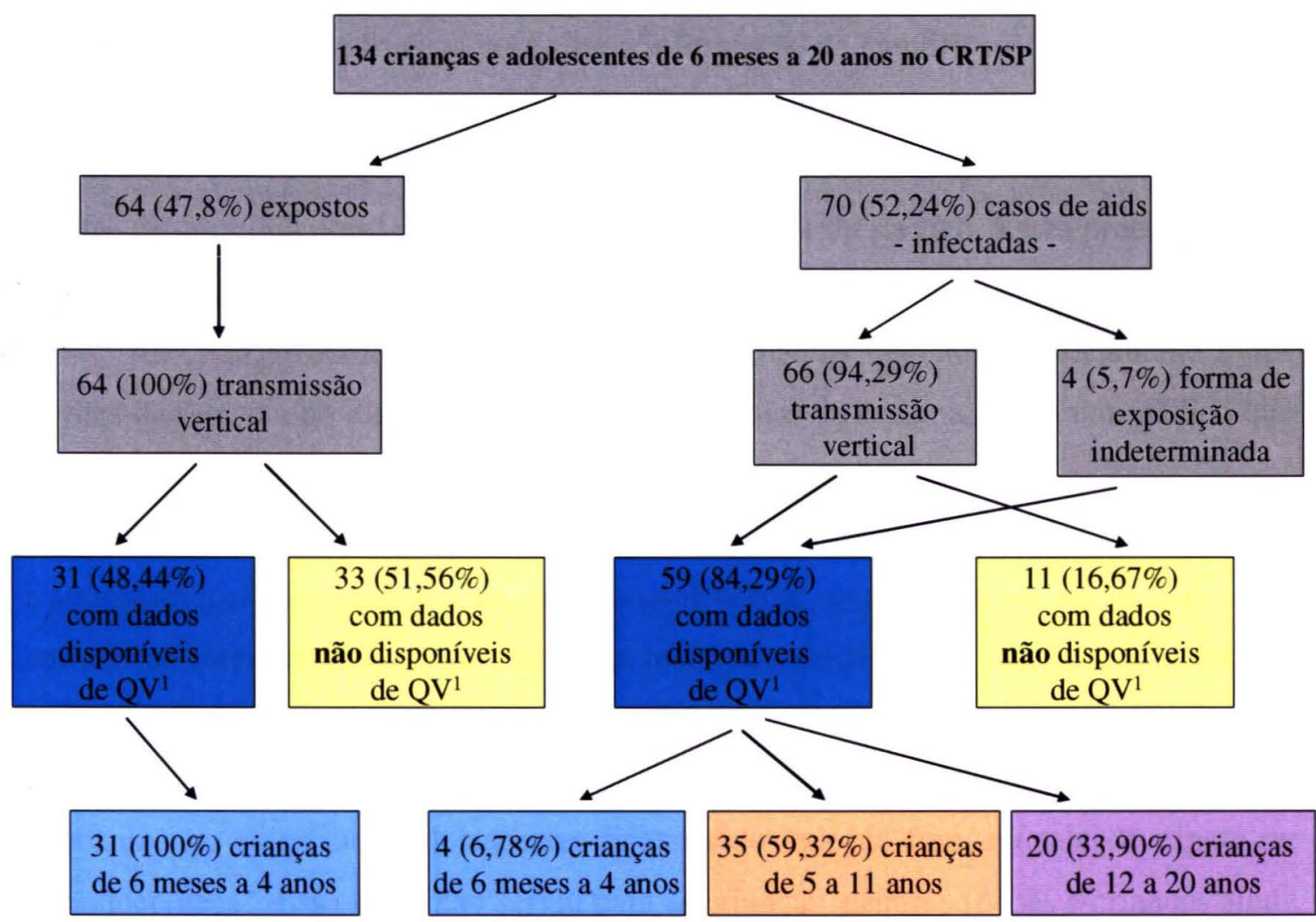

${ }^{1}$ QV: Qualidade de Vida.

Figura 1: Descrição das crianças e adolescentes registrados e da amostra deste estudo. 


\subsection{METODOLOGIA}

O projeto de pesquisa foi apresentado à diretoria do Hospital Dia do CRT/SP em dezembro de 2004, para verificar o interesse do serviço em colaborar com a pesquisa naquele local. Após discussão do projeto, foram incorporadas as sugestões e foi autorizada a sua realização.

Em março de 2005 foi obtida a lista das crianças/adolescentes atendidas no Hospital Dia do referido serviço. A partir dessa lista foi feito um caderno de controle das entrevistas e, pela ordem alfabética dos nomes, foi atribuído um número ao paciente, de forma que nos questionários da pesquisa, a informação de identificação que constava era somente este número e não o nome da criança/adolescente. No caderno de controle foram ainda colocadas informações sobre os pacientes como idade, médico responsável e datas de consulta, obtidas pelas agendas dos médicos do serviço. Esses procedimentos foram realizados para controle das possíveis perdas que ocorressem durante o estudo.

As crianças/adolescentes tinham os atendimentos marcados praticamente todos os dias da semana, de manhã e à tarde e, em dois dias da semana, havia um médico que fazia o atendimento à noite.

No dia da consulta de rotina, os pais/responsáveis eram convidados pelo médico responsável pelo atendimento da criança/adolescente, para participar da pesquisa. As entrevistas foram realizadas em uma sala reservada do Hospital Dia, chamada sala da enfermagem, onde as crianças eram pesadas e medidas. Os pais/responsáveis pelas crianças/adolescentes acompanhavam a aluna/pesquisadora até a sala reservada, enquanto que as crianças/adolescentes ficavam do lado de fora, na sala de espera ou "brinquedoteca". Essa regra não serviu para as crianças menores (bebês e crianças ainda de colo), que entravam junto com os pais/responsáveis. A aluna/pesquisadora apresentava a pesquisa, informava os objetivos, o caráter voluntário da participação, o sigilo das informações e a forma de preenchimento dos questionário. No final, a aluna lia e oferecia o termo de consentimento livre e esclarecido (Anexo 1) para ser assinado. Houve alguns casos de crianças que não quiseram ficar sem os pais/responsáveis e 
entraram na sala. Quando isso aconteceu, nenhuma referência à Aids ou ao HIV foi feita por parte da aluna/pesquisadora, pois, em muitos casos, as crianças até nove anos e mesmo alguns adolescentes não tinham o diagnóstico revelado.

Após esta etapa, era preenchido o questionário de características sóciodemográficas e familiares das crianças/adolescentes (Anexo 2). Depois disso, apresentava-se a versão em português do questionário de qualidade de vida específico para cada faixa etária (Anexos 3, 4 e 5) e perguntava-se se os pais/cuidadores podiam responder, uma vez que ele pode ser auto-respondido. Aqueles que concordavam em responder ficavam sozinhos na sala e preenchiam o questionário. A aluna/pesquisadora permanecia na sala de espera, ao lado da sala da pesquisa, para eventuais dúvidas e esclarecimentos. Aos que tinham alguma dificuldade em responder sozinhos, a aluna/pesquisadora preenchia o questionário na forma de entrevista. Depois disso, eram aplicados o questionário de adesão (Anexo 9) e a escala de auto-eficácia (Anexo 10), da mesma forma que o fora o questionário de qualidade de vida.

Por fim, era oferecida escala de maturação sexual (TANNER, 1962) para as crianças com mais de 7 anos (Anexo 11). As crianças maiores de 7 anos apontaram diante das figuras qual delas mais se aproximava do seu corpo e para, os menores, os próprios pais/cuidadores olhavam e preenchiam.

No caso dos adolescentes de 12 a 20 anos, foram oferecidos todos os questionários novamente e eles responderam, separados dos pais, aos questionários de qualidade de vida e de auto-eficácia para seguir prescrição anti-retroviral.

As entrevistas duraram em torno de 40 a 50 minutos, pois além de responderem as questões, alguns pais/responsáveis queriam falar sobre sua convivência com a doença. No final das entrevistas, o envelope contendo os questionários preenchidos era lacrado e identificado apenas pelo número de identificação do paciente e pela faixa etária.

Ao final do dia, a aluna/pesquisadora consultava as questões clínicas no prontuário do paciente (Anexo 12).

Os dados dos questionários de qualidade de vida, auto-eficácia para seguir prescrição anti-retroviral, características sócio-demográficas e clínicas foram digitados 
de forma duplicada e independente, a fim de se fazer um controle da qualidade e a consistência dos mesmos.

\subsubsection{Instrumentos Utilizados no Trabalho de Coleta dos Dados}

3.2.1.1 Questionário de Avaliação da Qualidade de Vida (Quality of Life Assessment)

Para avaliar a qualidade de vida das crianças e adolescentes com HIV/Aids foram utilizados os questionários específicos para cada faixa etária (6 meses a 4 anos, 5 a 11 anos e 12 a 20 anos, respectivamente Anexos 6,7 e 8). O instrumento foi baseado numa concepção multidimensional de qualidade de vida (GORTMAKER e col., 1998) e inclui os seguintes domínios: (1) Avaliação Geral da Saúde, (2) Avaliação do Estado Físico, (3) Avaliação das Atividades Pessoais e Sociais, (4) Utilização de Serviço de Saúde, (5) Sintomas ou Sinais e (6) Avaliação da Saúde Psicológica; sendo que esse último só existe na versão das duas faixas etárias mais velhas.

Os estudos de onde foram extraídos os domínios do questionário de qualidade de vida para crianças e adolescentes com HIV/Aids estão descritos a seguir:

Avaliação Geral da Saúde (6 meses a 20 anos de idade) - as questões foram adaptadas do questionário ACTG QOL para adultos (TESTA e LENDERKING, 1995) e de outro estudo com adultos (TESTA e SIMONSON, 1996).

Avaliação do Estado Físico (6 meses a 4 anos de idade) - essa escala é o Funcional Status II $(R)$ desenvolvida por STEIN e JESSOP (1990) que é usada para avaliar o Estado Físico de crianças com doenças crônicas. Segundo STORM e col. (2005), essa medida tem sido largamente utilizada e tem demonstrado boa validade em diferentes grupos de crianças.

Avaliação do Estado Físico (5 a 20 anos de idade) - os itens dessa escala são do questionário ACTG QOL para adultos (TESTA e LENDERKING, 1995) e foram 
desenvolvidos a partir do Medical Outcomes Study (STEWART e col., 1988). Essa escala verifica como a saúde tem interferido nas atividades físicas.

Resistência Física (6 meses a 11 anos) - utiliza, na sua composição, as questões do Child Health Supplement do National Health Interview Survey of 1988 (BROOK e col., 1979). Essa escala avalia a capacidade da criança se recuperar de desafios físicos e psicológicos/emocionais.

Avaliação da Saúde Psicológica (5 a 20 anos de idade) - essa escala é o Behavior Problem Index (BPI) adaptado do Child Behavior Checklist. É uma escala usada para avaliar problemas de comportamento e pode indicar que a criança está diante de dificuldades psicológicas. Estudos como o de GORTMAKER e col. (1990) e McCORMICK e col. (1992) mostraram a capacidade dessa escala discriminar crianças com e sem problemas crônicos. Os problemas crônicos avaliados no estudo de GORTMAKER e col. (1990) dizem respeito a 19 possíveis problemas de saúde que as crianças possam ter (asma, artrite, câncer, fibrose cística, diabetes, entre outros). Os autores concluem que as crianças/adolescentes com pelo menos um ou mais problemas crônicos apresentaram os maiores escores de BPI, quando comparadas com aquelas sem problemas crônicos.

Sintomas ou Sinais (6 meses a 20 anos de idade) - essa escala é composta por 18 questões do ACTG QOL para adultos (TESTA e LENDERKING, 1995) e é usada para verificar o quanto de desconforto a criança/adolescente sente diante dos sintomas. Estes sintomas incluem dor, sintomas gastrointestinais, sintomas respiratórios, febre ou perda de apetite e podem ser atribuídos a progressão da doença, efeitos colaterais de medicamentos ou intercorrência da própria doença. Outras 2 questões referentes a diarréia e dor de ouvido foram acrescentadas à escala, pois são mais comuns em crianças.

O domínio das Atividades Pessoais e Sociais inclui itens que descrevem diferentes tipos de constructos como limitações nas atividades diárias (respostas do tipo sim e não) e dias gastos ou passados na cama no último mês (número de dias). Esse tipo de constructo não chega a ser considerado uma escala e, sim, um índice, pois na sua 
composição existem questões do tipo sim e não (qualitativas nominais) e questões que são escalas (quantitativas contínuas) (LEE e col., 2006).

O domínio Utilização dos Serviços de Saúde é mais utilizado para fazer comparações com os outros domínios de qualidade de vida (GORTMAKER e col., 1998). Foram adotadas questões do National Center for Health Statistics (NHIS). Estas referem-se ao número de noites passadas no hospital nas últimas 4 semanas, ao número de visitas ao médico ou outro profissional de saúde, número de visitas domiciliares de enfermeiro ou outro profissional de saúde e número de vezes que ligou para uma clínica, médico, enfermeiro ou outro profissional de saúde para uma consulta, pelo telefone, acerca da saúde da criança.

\section{Cálculo dos escores de avaliação da qualidade de vida}

Os escores de qualidade de vida de cada domínio foram calculados para as faixas etárias específicas. Todos eles variam de 0 a 100 sendo que 0 indica uma pior qualidade de vida e 100 a melhor. Todas as fórmulas para o cálculo dos escores estão no Quadro 2 e foram enviadas pelos autores do questionário (Anexo 13).

Para cada domínio os escores foram calculados da seguinte maneira:

Escore do domínio de qualidade de vida= [(Soma máxima dos itens da escala Soma mínima dos itens da escala)/amplitude da escala] X 100.

O domínio de Avaliação Geral da Saúde, para as faixas etárias de 6 meses a 11 anos, é composto de 2 partes (A e B). A segunda parte é denominada, pelos autores, de Resistência Física.

Na Avaliação Geral da Saúde (6 meses a 20 anos) são 3 ou 4 perguntas sobre a saúde, dependendo da faixa etária, cuja resposta varia de 0 (pior do que ele/ela já sentiu) a 10 (melhor do que ele/ela já sentiu) e as respostas referem-se aos 3 últimos meses. 0 cálculo do escore para esse domínio está no Quadro 2.

Na segunda parte (B), de Resistência Física (6 meses a 11 anos), as questões são 7 frases ou afirmações sobre a saúde da criança/adolescente. Diante dessas frases, 
sempre referentes aos três últimos meses, os pais/cuidadores escolhem uma das opções: (1) nunca ou raramente, (2) durante algum tempo, (3) quase sempre ou sempre. Para o cálculo deste escore, 4 questões $(3,4,5$ e 6) tiveram o valor da resposta recodificado no sentido reverso: $(1=3),(2=2)$ e (3=1). O cálculo do escore encontra-se no Quadro 2.

No domínio de Avaliação do Estado Físico (6 meses a 4 anos de idade), os pais/cuidadores têm diante de si 15 situações referentes a alimentação, sono, humor, cansaço, comunicação, estímulo, choro, entre outras, diante das quais respondem, em relação aos últimos 3 meses, (1) nunca ou raramente, (2) durante algum tempo, (3) quase sempre ou sempre. A questão de número 15 desse domínio é referente ao uso de algum equipamento ou aparelho médico no dia a dia e foi retirada quando do cálculo do escore, pois, segundo os autores, ela é influenciada por fatores externos e pode não ser apropriada para a maior parte das crianças.

Para o cálculo do escore (Quadro 2) 5 questões $(4,6,9,12$ e 14) tiveram o valor da resposta recodificado no sentido reverso, a saber: $(1=3),(2=2)$ e $(3=1)$.

No domínio de Avaliação do Estado Físico (5 a 20 anos de idade) são 6 questões diante das quais os pais/cuidadores apontam o quanto a saúde da criança/adolescente interferiu em seis aspectos de atividade física, nas 4 últimas semanas, e as respostas possíveis são: (1) nada/nem um pouco, (2) um pouco, (3) moderadamente (mais ou menos), (4) muito, (5) demais.

Para o cálculo do escore (Quadro 2), todas as questões tiveram o valor da resposta recodificado no sentido reverso, a saber: $(1=5),(2=4),(3=3),(4=2)$ e $(5=1)$, de modo que valores maiores representem uma melhor qualidade de vida.

O domínio de Avaliação da Saúde Psicológica (5 a 20 anos de idade) é representado por uma escala composta de 28 possíveis problemas comportamentais que as crianças podem ter. Diante de cada problema, os pais/cuidadores devem assinalar se o mesmo ocorre (1) muitas vezes, (2) algumas vezes ou (3) nunca. As questões 24-27 são diferentes para as faixas de 5-11 e 12 a 20 anos. As questões referem-se sempre aos três últimos meses. 
O domínio de Avaliação das Atividades Pessoais e Sociais (6 meses a 4 anos) é composto de duas partes (A e B).

Na primeira parte (parte A) são duas questões, sendo que a primeira delas referese ao número de dias que a criança ficou na cama devido a alguma doença e a segunda (parte B) refere-se ao número de dias que a criança ficou fora da escola/creche, sempre em relação às 4 últimas semanas. As opções de resposta para estas duas questões são: (1) nenhum dia, (2) 1 a 2 dias, (3) 3 a 5 dias, (4) 6 a 10 dias, (5) 11 a 15 dias e (6) mais que 16 dias. Para o cálculo do escore, as respostas dessas duas questões foram recodificadas para $(1=6),(2=5),(3=4),(4=3),(5=2)$ e $(6=1)$, afim de que valores maiores representem melhores situações.

Na segunda parte (B), são 5 questões referentes às 4 últimas semanas, sobre as atividades que as crianças costumam participar (jogos, esportes, brincadeiras com outras crianças), e as respostas são do tipo sim e não. A questão 6 diz respeito a quem cuidou da criança durante os dias da semana, e não entrou no cálculo do escore.

Para o cálculo do escore foram consideradas as partes A (questões 1 e 2) e B (questões 1, 2, 3, 4 e 5) desse domínio (Quadro 2).

Para a faixa etária de 5 a 20 anos, o domínio de Avaliação das Atividades Pessoais e Sociais também é composto de duas partes (A e B). A parte A é idêntica àquela já descrita para a faixa de 6 meses a 4 anos. Na parte $B$, as questões referem-se às situações escolares (repetiu alguma série, freqüência na escola comprometida, atividade física na escola) e as opções de resposta são do tipo sim e não. A questão 1 da parte $B$ diz respeito ao grau de escolaridade da criança/adolescente e não entrou no cálculo do escore. Para o cálculo do escore foram consideradas as partes A (questões 1 e 2) e B (questões 2, 3, 4, 5 e 6) desse domínio (Quadro 2). O escore do domínio varia de 0 a 100 , sendo que 0 indica uma pior qualidade de vida e 100 uma melhor qualidade de vida.

O domínio de Utilização dos Serviços de Saúde (6 meses a 20 anos) é composto de 3 partes (A, B e C). Na parte A são 4 questões referentes às 4 últimas semanas em que se pergunta: (1) número de noites de hospitalização, (2) número de visitas ao 
médico, enfermeiro ou outro especialista, (3) número de vezes que recebeu visitas de um profissional de saúde em casa e (4) número de vezes que os pais/cuidadores ligaram para o médico ou outro profissional de saúde para uma consulta pelo telefone. As opções de resposta para as 4 questões são: (1) nenhum, (2) 1 a 2 dias, (3) 3 a 5 dias, (4) 6 a 10 dias, (5) 11 a 15 dias e (6) mais que 20 dias. Para o cálculo do escore, as respostas dessas quatro questões foram recodificadas para $(1=6),(2=5),(3=4),(4=3),(5=2)$ e $(6=1)$, afim de que valores maiores representem melhores situações. Na parte B são 6 questões que referem-se ao uso de medicação, nas últimas 4 semanas, e as respostas são do tipo sim e não. $\mathrm{Na}$ parte $\mathrm{C}$ são 10 questões que referem-se aos tratamentos alternativos que as crianças/adolescentes possam estar fazendo.

Para o cálculo do escore (Quadro 2), seguindo as orientações dos autores, foram consideradas somente as partes A e B desse domínio.

No domínio de Sintomas ou Sinais ( 0 a 20 anos de idade), os pais/cuidadores, devem dizer o quanto de desconforto os 20 sintomas apresentados causaram em sua criança, nas 4 últimas semanas. As respostas possíveis são: (1) nem um pouco, (2) muito pouco, (3) pouco, (4) moderadamente (mais ou menos), (5) muito ou (6) demais.

Para o cálculo do escore (Quadro 2), todas as questões tiveram o valor da resposta recodificado no sentido reverso, a saber: $(1=6),(2=5),(3=4),(4=3),(5=2)$ e $(6=1)$ de modo que os valores maiores expressem uma melhor situação. 
Quadro 2: Fórmulas para o cálculo dos escores de qualidade de vida.

\begin{tabular}{|c|c|c|c|c|c|}
\hline Domínio & Faixa etária & Fórmula & \multicolumn{3}{|c|}{ Valores da soma dos escores } \\
\hline & & & Mínimo & Máximo & Amplitude \\
\hline I. Avaliação Geral da Saúde & $\begin{array}{l}6 \text { meses a } 4 \\
\text { anos }\end{array}$ & {$[(\mathrm{QIA} 1+\mathrm{QIA} 2+\mathrm{QIA} 3-3) / 27] * 100$} & 3 & 30 & 27 \\
\hline & 5 a 20 anos & {$[(\mathrm{QIA} 1+\mathrm{QIA} 2$ + QIA3 + QIA4 - 4)/36]*100 } & 4 & 40 & 36 \\
\hline I. Resistência Física & $\begin{array}{l}6 \text { meses a } 11 \\
\text { anos }\end{array}$ & [(QIB1+QIB2+QIB3+QIB4+QIB5+QIB6+QIB7-7)/14]*100 & 7 & 21 & 14 \\
\hline $\begin{array}{l}\text { II. Avaliação do Estado } \\
\text { Físico }\end{array}$ & $\begin{array}{l}6 \text { meses a } 4 \\
\text { anos }\end{array}$ & $\begin{array}{l}\text { [(QII1+QII2+QII3+QII4+QII5+QII6+QII7+QII8+QII9+QII10+ } \\
\text { QII11+QII12+QII13+QII14-14)/28]*100 }\end{array}$ & 14 & 42 & 28 \\
\hline & 5 a 20 anos & [(QII1 + QII2 + QII3 + QII4 + QII5 + QII6 - 6)/24]*100 & 6 & 30 & 24 \\
\hline $\begin{array}{l}\text { III. Avaliação da Saúde } \\
\text { Psicológica }\end{array}$ & 5 a 20 anos & {$[(\mathrm{QIII} 1+\mathrm{QIII} 2+\mathrm{QIII} 3+\ldots+\mathrm{QIII28-28)/56]*100}$} & 28 & 84 & 56 \\
\hline $\begin{array}{l}\text { IV. Avaliação das Atividades } \\
\text { Pessoais e Sociais }\end{array}$ & $\begin{array}{l}\text { meses a } 4 \\
\text { anos }\end{array}$ & $\begin{array}{l}\text { [(QIVA1+QIVA2+QIVB1+QIVB2+QIVB3+QIVB4+QIVB5- } \\
\text { 7)/15]*100 }\end{array}$ & 7 & 22 & 15 \\
\hline & 5 a 20 anos & $\begin{array}{l}\text { [(QIVA1+QIVA2+QIVB2+QIVB3+QIVB4+QIVB5+QIVB6)- } \\
\text { 7)/15]*100 }\end{array}$ & 7 & 22 & 15 \\
\hline $\begin{array}{l}\text { V. Utilização dos Serviços } \\
\text { de Saúde }\end{array}$ & $\begin{array}{l}6 \text { meses a } 20 \\
\text { anos }\end{array}$ & $\begin{array}{l}\text { [(QVA1+QVA2+QVA3+QVA4+QVB1+QVB2+QVB3+QVB4+ } \\
\text { QVB5+QVB6-10)/26]*100 }\end{array}$ & 10 & 36 & 26 \\
\hline VI. Sintomas ou Sinais & $\begin{array}{l}6 \text { meses a } 20 \\
\text { anos }\end{array}$ & {$[(Q V I 1+Q V I 2+Q V I 3+\ldots+Q V I 20-20) / 100] * 100$} & 20 & 120 & 100 \\
\hline
\end{tabular}




\subsubsection{Escala de Auto-Eficácia para Seguir Prescrição Anti-}

Retroviral (AE)

Essa escala foi desenvolvida por LEITE e col. (2002) de modo que os itens refletissem a experiência de sujeitos em tratamento para HIV/Aids no Brasil. Os autores realizaram entrevistas individuais e em grupo com pacientes de um serviço público de Pelotas, no Rio Grande do Sul, de acordo com um roteiro temático para questões semiabertas que abordavam quatro grandes temas: a) a experiência de ser HIV positivo, de apresentar ou não Aids, e de receber a indicação de tratamento anti-retroviral; b) as percepções e as expectativas de resultados - vantagens e desvantagens de seguir regularmente a prescrição; c) as percepções e as expectativas de resultado de não tomar os anti-retrovirais ou não seguir regularmente a prescrição; e d) situações que dificultam ou facilitam o uso prescrito, incluindo percepções e expectativas da capacidade de superar obstáculos ao seguimento da prescrição.

Os itens da escala foram desenvolvidos pela análise de conteúdo dos depoimentos dos participantes. A escala é composta de 21 itens ou situações onde o paciente aponta diante de diversas situações se vai conseguir tomar os medicamentos anti-retrovirais prescritos pelo médico. As situações correspondem a atividades que exigem concentração, atividades não-rotineiras ou fora de casa e situações sociais de lazer, situações que tendem a diminuir a preocupação com a doença ou confiança no tratamento, situações que envolvem experiências negativas com a medicação antiretroviral e afetos negativos de qualquer natureza (como gosto ruim do medicamento, dificuldade para engolir, cheiro forte, efeitos adversos, sentir-se deprimido, discriminado, entre outros). Para cada uma das 21 questões as opções de resposta são: 0 - não vou tomar mesmo, 1- acho que não vou tomar, 2 - não sei, 3 - acho que vou tomar e 4 - com certeza vou tomar.

Como nesta pesquisa os pais/cuidadores responderam pelas crianças/adolescentes, tanto as questões da escala como as respostas foram adaptadas para que esta situação fosse contemplada (Anexo 10). 
Segundo os autores os escores podem ser calculados de duas maneiras:

1) Pode-se fazer uma análise fatorial exploratória utilizando a técnica dos componentes principais para a extração dos fatores, utilizando a rotação varimax. Nesta tese adotou-se, como ponto de corte para o coeficiente de correlação, 0,30 e foi considerado apenas o primeiro fator. Nesta análise foi estimado um coeficiente de regressão para cada questão e o escore de auto-eficácia foi calculado a partir da somatória dos produtos entre a questão e o respectivo coeficiente de regressão $\left(\sum_{i=1 a 21}(\beta i * \mathrm{~A} i)\right)$.

Sejam: $\beta_{i}$ 's os parâmetros/coeficientes de regressão e $A_{i}$ 's as questões do questionário de auto-eficácia ( $\mathrm{i}=1$ a 21 ). $\mathrm{O}$ cálculo do escore seria:

$$
\text { Escore-1 de auto-eficácia }(\mathrm{AE} 1)=\sum_{i=1 a 21}(\beta i * \mathrm{~A} i)
$$

Por último este escore foi padronizado através da transformação para um $\mathbf{z}$ escore. No escore padronizado, quando a média é zero significa que a auto-eficácia é igual à média da amostra. Valores negativos do escore indicam uma pior auto-eficácia e valores positivos uma melhor auto-eficácia para seguir prescrição anti-retroviral.

\section{Escore-1 de auto-eficácia padronizado $=\underline{\mathrm{AE} 1-\text { Média amostral }}$ \\ Desvio-padrão}

2) Uma segunda maneira de calcular este escore seria pela soma das 21 questões. Somam-se os valores das respostas, subtrai-se desse valor o mínimo assumido pela escala (no caso, zero), divide-se pela amplitude da escala (84-0), e então multiplica-se por 100. Este escore pode variar de 0 a 100, e quanto maior o escore, maior é a autoeficácia para seguir prescrição anti-retroviral. 
Escore-2 de auto-eficácia $(\mathrm{AE2})=\left[\frac{\left(\sum_{i=1 a 21} \mathrm{~A} i\right)-0}{84}\right] * 100$

\subsubsection{Questionário de Características Sócio-Demográficas}

É um questionário composto por questões sobre as crianças/adolescentes bem como por questões referentes a sua estrutura familiar (Anexo 2). As questões sobre as crianças/adolescentes referem-se ao sexo, cor da pele, data de nascimento, até qual série escolar havia completado, número de horas na escola, peso e altura nos últimos três meses, se já havia tido menarca ou semenarca (com que idade) e com quem a criança/adolescente mora (se com a família ou em casa de apoio) e quem é o cuidador da criança. As questões referentes aos familiares e moradores são sobre sexo, idade, escolaridade, renda e ocupação. Também constam questões sobre etilismo, tabagismo e uso de drogas ilícitas (quais) nos últimos três meses por parte do pai e/ou da mãe e questões sobre etilismo, tabagismo e uso de drogas ilícitas pela mãe durante a gravidez.

\subsubsection{Questionário de Aderência ao Tratamento Anti-}

Retroviral

Este é um questionário que tem sido utilizado em estudos multicêntricos denominados "PENTA" (GIBB e col., 2003). As questões são referentes aos medicamentos que a criança/adolescente toma, ao grau de dificuldade/facilidade para tomá-los, às doses tomadas, ao quanto tomar os medicamentos interfere na vida diária, tanto de quem os administra, como de quem os toma. Além disso, são feitas perguntas sobre o grau de importância em tomar os medicamentos, sobre os horários das doses, razões para ter deixado de dar algumas doses, rotina para administrá-los (com comida/sem comida) e doses de cada medicamento deixadas de tomar nos três últimos 
dias. Também nesse questionário foi anotado o quanto (doses) de cada medicamento a criança usava por dia (Anexo 9).

\subsubsection{Questionário de Características Clínicas da}

\section{Criança/Adolescente}

É um questionário composto por questões antropométricas e clínicas da criança/adolescente. Tais questões foram extraídas dos prontuários dos pacientes. As questões antropométricas são sobre peso e altura, nos últimos três meses; as questões clínicas são referentes à data de entrada no serviço, data de diagnóstico do HIV, modo de transmissão - vertical, transfusional, vertical sem HIV (expostos), indeterminado, classificação do CDC (inicial e atual), contagem de células TCD4+ (em n absoluto/mm²) inicial e nos últimos três meses, carga viral (cópias $/ \mathrm{mm}$ ) inicial e nos últimos três meses. Também constam desse questionário questões referentes ao tratamento anti-retroviral como o paciente recebe drogas anti-retrovirais, se teve a profilaxia PACTG076, esquema nos últimos três meses (duplo, triplo, outro, nenhum), esquema de resgate, mudanças de esquemas terapêuticos, uso de medicamentos anti-retrovirais, uso de outros medicamentos não anti-retrovirais, profilaxia primária e secundária para Pneumocistys Carinii, uso de gamaglobulina endovenosa mensal e, internações (Anexo 12).

\section{Maturação Sexual}

As informações sobre maturação foram coletadas por meio dos desenhos propostos por Tanner (TANNER, 1962). As crianças/adolescentes acima de 7 anos receberam orientação para assinalarem a figura (Anexo 11) que mais se assemelhava à percepção que ele tem de si próprio. As características de maturação sexual secundárias foram avaliadas pelo desenvolvimento da genitália e da pilosidade pubiana para os meninos. Entre as meninas foi verificado o desenvolvimento das mamas e a pilosidade pubiana. 
O Quadro 3 ilustra a classificação proposta pela Organização Mundial da Saúde (WHO, 1995) que leva em consideração o desenvolvimento das mamas para o sexo feminino e da genitália para o sexo masculino.

Quadro 3 - Classificação da maturação sexual para os estágios de Tanner.

\begin{tabular}{|l|l|l|}
\hline \multicolumn{1}{|c|}{ SEXO } & \multicolumn{1}{|c|}{ ESTÁGIO } & \multicolumn{1}{c|}{ CLASSIFICAÇÃO } \\
\hline \multirow{2}{*}{ Feminino } & Mamas estágio M1 & Pré-púberes \\
\cline { 2 - 3 } & Mamas estágio M2 a M5 & Púberes \\
\hline \multirow{2}{*}{ Masculino } & Genitália estágio G1 & Pré-púberes \\
\cline { 2 - 3 } & Genitália estágios G2 a G5 & Púberes \\
\hline
\end{tabular}

Fonte: Adaptado de WHO (1995) 


\subsubsection{Variáveis de Estudo}

A descrição das variáveis de estudo encontra-se nos Quadros 4 a 6.

Quadro 4: Características sócio-demográficas e clínicas das crianças/adolescentes.

\begin{tabular}{|c|c|c|}
\hline Variável & Tipo de variável & Categoria \\
\hline - Sexo & Qualitativa nominal & masculino, feminino \\
\hline - Cor da pele & Qualitativa nominal & branco, não branco \\
\hline - Faixa de idade & Qualitativa ordinal & $\begin{array}{l}6 \text { a } 59 \text { meses, } 60 \text { a } 143 \text { meses, } 144 \text { a } \\
251 \text { meses }\end{array}$ \\
\hline - Escolaridade & Qualitativa ordinal & $\begin{array}{l}\text { não estuda, berçário/maternal/pré-escola } \\
\text { jardim, } 1^{\mathrm{a}}-4^{\mathrm{a}} \text { série ensino fundamental, } \\
5^{\mathrm{a}}-8^{\mathrm{a}} \text { série ensino fundamental, } \\
1^{\mathrm{a}}-3^{\mathrm{a}} \text { série ensino médio }\end{array}$ \\
\hline - Ano no CRT/Aids & Qualitativa ordinal & $1989-1995,1996-2000$ e $2001-2005$ \\
\hline - Ano do diagnóstico & Qualitativa ordinal & $1989-1995,1996-2000$ e $2001-2005$ \\
\hline - Classe CDC atual & Qualitativa ordinal & 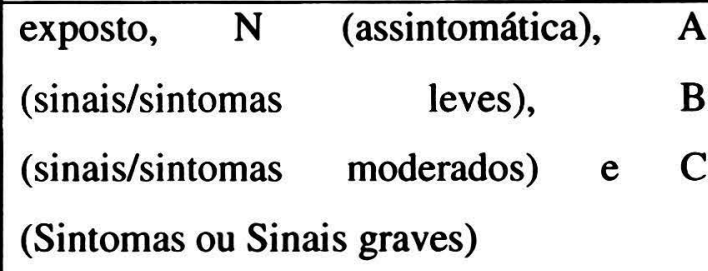 \\
\hline - Droga ARV & Qualitativa nominal & sim, não \\
\hline - PACTG076 & Qualitativa nominal & sim, não, incompleto \\
\hline - Esquema de Resgate & Qualitativa nominal & sim, não \\
\hline $\begin{array}{l}\text { Grupo CDC (6meses a } 4 \\
\text { anos) }\end{array}$ & Qualitativa nominal & $\begin{array}{lll}\text { não doente } & \text { (expostas), doente } \\
\text { (infectadas) } & \end{array}$ \\
\hline - Grupo CDC (5 a 20 anos) & Qualitativa nominal & não doente $(\mathrm{N}+\mathrm{A})$, doente $(\mathrm{B}+\mathrm{C})$ \\
\hline - Número de noites no hospital & Quantitativa contínua & escore variando de 1 a 6 \\
\hline - Número de visitas ao serviço & Quantitativa contínua & escore variando de 1 a 6 \\
\hline
\end{tabular}


Quadro 4: Características sócio-demográficas e clínicas das crianças/adolescentes. Continuação.

\begin{tabular}{|c|c|c|}
\hline Variável & Tipo de variável & Categoria \\
\hline - CD4 (log) & $\begin{array}{l}\text { Quantitativa } \\
\text { contínua }\end{array}$ & Em número absoluto/mm $\mathrm{m}^{3}$ \\
\hline - Carga viral (log) & $\begin{array}{l}\text { Quantitativa } \\
\text { contínua }\end{array}$ & cópias/mm \\
\hline $\begin{array}{l}\text { Deixou de tomar } \\
\text { medicamentos (3 últimos dias) }\end{array}$ & Qualitativa nominal & sim, não \\
\hline $\begin{array}{l}\text { Quantidade de medicamentos } \\
\text { tomada nos } 3 \text { últimos dias (em } \\
\text { ml ou comprimidos) }\end{array}$ & $\begin{array}{l}\text { Quantitativa } \\
\text { contínua }\end{array}$ & Em ml ou comprimidos \\
\hline $\begin{array}{l}\text { Quantidade de medicamentos } \\
\text { prescrita nos } 3 \text { últimos dias (em } \\
\text { ml ou comprimidos) }\end{array}$ & $\begin{array}{l}\text { Quantitativa } \\
\text { contínua }\end{array}$ & Em ml ou comprimidos \\
\hline - \% adesão & $\begin{array}{l}\text { Quantitativa } \\
\text { contínua }\end{array}$ & 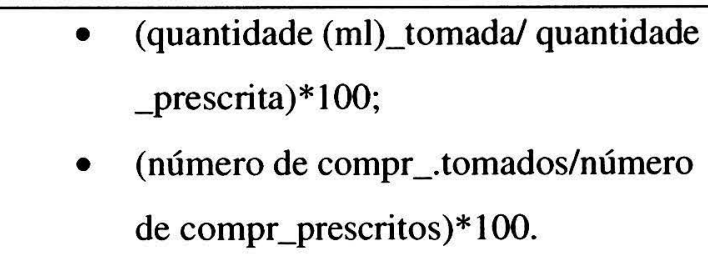 \\
\hline - \% média de adesão & $\begin{array}{l}\text { Quantitativa } \\
\text { contínua }\end{array}$ & $\begin{array}{l}\text { Soma_\% adesão (cada } \\
\text { medicamento)/número de medicamentos }\end{array}$ \\
\hline - Adesão & Qualitativa nominal & $\begin{array}{l}\text { aderente ( } \% \text { média de adesão >=95\% ), } \\
\text { não-aderente ( } \% \text { média de adesão < } 95 \% \text { ) }\end{array}$ \\
\hline
\end{tabular}


Quadro 5: Características do respondente.

\begin{tabular}{|c|c|c|}
\hline Variável & Tipo de variável & Categoria \\
\hline - Pessoa (respondente) & Qualitativa nominal & $\begin{array}{l}\text { Avó/avô,irmã, mãe, pai, tia/tio e } \\
\text { adolescente }>18 \text { ano }\end{array}$ \\
\hline - Sexo & Qualitativa nominal & masculino, feminino \\
\hline - Idade (anos) & Qualitativa ordinal & $19-30,31-39,40-73$ \\
\hline - Escolaridade & Qualitativa ordinal & 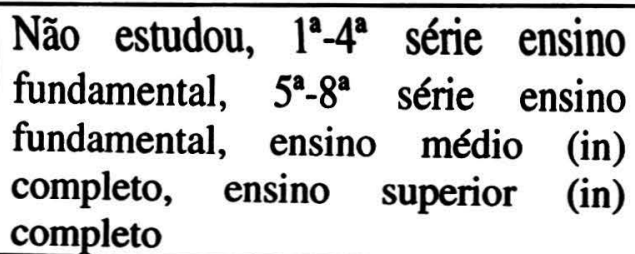 \\
\hline - Renda & Qualitativa ordinal & $\begin{array}{l}\text { não tem, até } R \$ 300,00 \text {, de } R \$ \\
301,00-600,00 \text {, de } R \$ 601,00- \\
2700,00\end{array}$ \\
\hline
\end{tabular}


Quadro 6: Variáveis do questionário de qualidade de vida e da escala de auto-eficácia.

\begin{tabular}{|ll|l|l|}
\hline Variável & Tipo de variável & Escore variando de: \\
\hline $\begin{array}{l}\text { Avaliação Geral da } \\
\text { Saúde }\end{array}$ & Quantitativa contínua & 0 a 100 \\
\hline$\bullet$ & $\begin{array}{l}\text { Avaliação do Estado } \\
\text { Físico }\end{array}$ & Quantitativa contínua & 0 a 100 \\
\hline$\bullet$ & Resistência Física & Quantitativa contínua & 0 a 100 \\
\hline$\bullet$ & $\begin{array}{l}\text { Avaliação da Saúde } \\
\text { Psicológica }\end{array}$ & Quantitativa contínua & 0 a 100 \\
\hline$\bullet$ & $\begin{array}{l}\text { Avaliação das } \\
\text { Atividades Pessoais e } \\
\text { Sociais }\end{array}$ & Quantitativa contínua & 0 a 100 \\
\hline$\bullet$ & $\begin{array}{l}\text { Utilização dos Serviços } \\
\text { de Saúde }\end{array}$ & Quantitativa contínua & 0 a 100 \\
\hline$\bullet$ & Sintomas ou Sinais & Quantitativa contínua & 0 a 100 \\
\hline$\bullet$ & $\begin{array}{l}\text { Escore-1 de auto- } \\
\text { eficácia }\end{array}$ & Quantitativa contínua & -1 a 1 \\
\hline $\begin{array}{l}\text { Escore-2 de auto- } \\
\text { eficácia }\end{array}$ & Quantitativa contínua & de 0 a 100 \\
\hline
\end{tabular}




\subsection{TRADUÇÃO}

O objetivo da tradução é encontrar equivalência entre a versão original e a versão traduzida do questionário (STREINER e NORMAN, 2003). O modelo de avaliação de equivalência transcultural proposto por HERDMAN e col. (1998), de acordo com HASSELMANN e REICHENHEIM (2003) abrange seis tipos de equivalência: 1 e 2) Avaliação da equivalência conceitual e de itens, 3) Avaliação da equivalência semântica, 4) Equivalência operacional, 5) Equivalência de mensuração e 6) Equivalência funcional. Neste estudo foram considerados o quatro primeiros itens na fase de tradução, retrotradução e adaptação cultural e os dois últimos na validação e reprodutibilidade.

\subsubsection{Avaliação da Equivalência Conceitual e de Itens}

Esta avaliação consistiu na discussão entre três pesquisadores (a aluna/pesquisadora, sua orientadora e sua co-orientadora) sendo que um deles trabalha diretamente na prática pediátrica com crianças e adolescentes com HIV/Aids. A discussão teve a finalidade de verificar a pertinência dos itens do instrumento original para captação de cada uma das dimensões da qualidade de vida em crianças e adolescentes com HIV/Aids e, também, a pertinência do instrumento no contexto brasileiro.

\subsubsection{Avaliação da Equivalência Semântica}

Esta avaliação diz respeito à capacidade de transferência dos significados das palavras entre idiomas distintos (do instrumento original para a versão) afim de que o impacto nos respondentes seja semelhante quando se consideram as diferentes culturas. O significado, em si, pode estar articulado às idéias e associações ligadas a uma palavra ou várias palavras, pelas experiências individuais ou coletivas (conotativo), ou ainda, se referir ao sentido geral de cada item, captado por meio do instrumento original em 
comparação com a tradução (referencial) (HERDMAN e col., 1998; HASSELMANN e REICHENHEIM, 2003). O processo de avaliação semântica envolveu três etapas neste estudo.

A primeira foi a realização de três traduções do original em inglês para o português, realizadas de forma independente, por três pesquisadores experientes e após, foi feita uma versão única para o português .

$\mathrm{Na}$ segunda etapa do processo, a versão em português foi traduzida para o inglês por um pesquisador nativo dos EUA. Neste processo avaliou-se a equivalência entre o original e a retradução, sob a perspectiva do significado referencial dos termos/palavras, ou seja, se há uma correspondência literal entre as palavras do original e aquelas da retradução. Um outro aspecto considerado foi o significado geral de cada item/questão no contexto cultural da população alvo, pois algumas questões podem perder significado em um novo contexto sócio-cultural.

$\mathrm{Na}$ terceira etapa os três pesquisadores identificaram e resolveram as discrepâncias ocorridas em cada uma das etapas anteriores, obtendo-se a versão final em português do questionário Quality of life Assessment. As versões em português encontram-se nos Anexos 3, 4 e 5, respectivamente para as faixas etárias 6 meses a 4 anos, 5 a 11 anos e 12 a 20 anos.

\subsubsection{Avaliação da Equivalência de Mensuração}

Consiste em avaliar as medidas de confiabilidade e validade da versão do instrumento, comparando-as com as encontradas no instrumento original (HASSELMAN e REICHENHEIM, 2003). No caso da versão do questionário de qualidade de vida e da escala de auto-eficácia foram verificadas a consistência interna, dois aspectos da validade de constructo e a reprodutibilidade. Além disso, para o questionário de qualidade de vida foi realizada a análise fatorial confirmatória. As análises referentes à avaliação da equivalência de mensuração estão melhor detalhadas na próxima seção. 


\subsection{ANÁLISE DOS DADOS}

\subsubsection{Caracterização da Amostra}

Foi realizada análise descritiva para os escores de cada domínio do questionário de qualidade de vida e, também, para os dois escores de auto-eficácia para seguir prescrição anti-retroviral. Foram calculadas médias, desvios-padrão, valores mínimos e máximos para os escores e feito o teste de aderência à curva normal (teste de Kolmogorov-Smirnov) para os escores de qualidade de vida e de auto-eficácia. Para as variáveis qualitativas foram calculadas as proporções.

\subsubsection{Equivalência de Mensuração}

\subsubsection{Consistência Interna}

A consistência interna foi analisada usando o coeficiente $\alpha$ de Cronbach. Esse coeficiente estima a média das correlações de cada item com o escore total formado pelos itens. Considera-se que questionário tem uma boa consistência interna quando os $\alpha^{\prime}$ s de Cronbach estão acima de 0,70 (Nunally apud STREINER e NORMAN, 2003).

Foram calculados os $\alpha$ 's de Cronbach para todos os domínios do questionário de qualidade de vida, para as três faixas etárias estudadas e para o escore de auto-eficácia para seguir prescrição anti-retroviral. 


\subsubsection{Análise Fatorial}

\subsection{Qualidade de Vida}

Realizou-se uma análise fatorial confirmatória, pois foi assumida uma estrutura fatorial conhecida para o questionário de avaliação da qualidade de vida (SHARMA, 1996). A Figura 2 ilustra esta estrutura fatorial estabelecida a priori. Parte-se do pressuposto que a qualidade de vida é uma grande dimensão composta de sete fatores ou dimensões e cada uma destas dimensões é medida pelas questões que as compõem. Estas questões medem um e somente um fator ou dimensão, sendo que o objetivo desta análise é verificar ou confirmar empiricamente a estrutura fatorial já elaborada pelos idealizadores do questionário de avaliação da qualidade de vida.

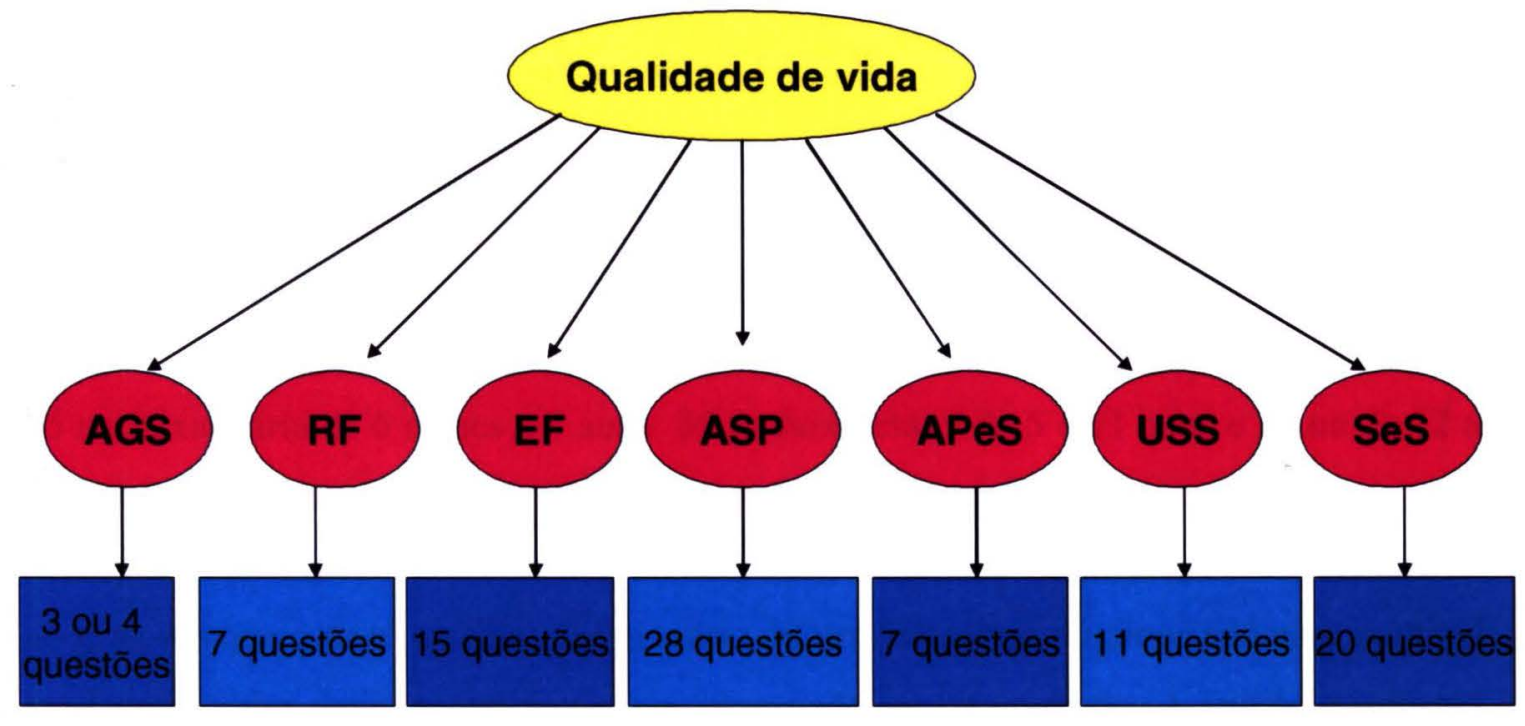

AGS: Avaliação Geral da Saúde

RF: Resistência Física

EF: Estado Físico
ASP: Avaliação da Saúde Psicológica

APS: Atividades Pessoais e Sociais

USS: Utilização dos Serviços de Saúde

SeS: Sintomas ou Sinais

Figura 2: Modelo fatorial confirmatório para a qualidade de vida. 
A análise fatorial foi realizada utilizando o método de JÖRESKOG e MOUSTAKI (2006) para estimar modelos fatoriais quando as variáveis são qualitativas ordinais. Este método baseia-se em informações univariadas e bivariadas para as estimativas de parâmetros (FIML - Full Information Likelihood Methods). A estimativa da função de verossimilhança foi calculada a partir da função logística e o software utilizado foi o LISREL versão 8.80 .

\subsection{Auto-Eficácia}

Para a escala de auto-eficácia foi realizada análise fatorial exploratória para formação do escore-1 de auto-eficácia, pelo método dos componentes principais usando a rotação varimax. Como a análise fatorial neste contexto teve por objetivo a formação do escore de auto-eficácia, fixou-se somente um fator no momento da análise e optou-se por selecionar as questões que apresentaram $r>0,30$.

\subsubsection{Validação}

A análise da validação também foi realizada com 90 crianças/adolescentes sendo 35 na faixa etária de 6 meses a 4 anos, 35 na faixa etária de 5 a 11 anos e 20 na de 12 a 20 anos.

Validade (acuidade, acurácia ou exatidão; em inglês: validity, accuracỳ) refere-se ao grau em que o teste, exame, questionário ou procedimento é apropriado para medir o verdadeiro valor daquilo que é medido, observado ou interpretado. A validade informa se os resultados daquilo que foi medido representam a "verdade" ou o quanto se afastam dela (PEREIRA, 1995a). Para STREINER e NORMAN (2003) validar uma escala é um processo onde se determina o grau de confiança que se pode ter nas inferências sobre pessoas, baseada nos escores da escala.

Neste estudo a validade foi verificada pela validade de constructo que refere-se à capacidade do instrumento em medir constructos teóricos, ou seja, verificar se ele 
realmente reflete adequadamente algumas hipóteses estabelecidas a priori (JENNEY e CAMPBELL, 1997). O constructo pode ser entendido, de acordo com STREINER e NORMAN (2003), como uma 'mini-teoria' para explicar as relações entre vários comportamentos ou atitudes. Os autores colocam ainda que os constructos podem ser baseados em observações clínicas. Assim, para verificar a validade de constructo neste estudo foram comparadas as médias dos escores das crianças/adolescentes com diferentes características clínicas, afim de verificar se os instrumentos em estudo conseguem distinguir entre grupos (DE BOER e col., 1995). Também foi verificada a capacidade dos instrumentos se correlacionarem em magnitude e direção com uma hipótese pré-definida (validade convergente) (DE BOER e col., 1995).

\subsection{Qualidade de Vida}

Para a validação do questionário de qualidade de vida foram utilizadas as seguintes estratégias:

1) Foi feita a comparação das médias dos escores de qualidade de vida, segundo grupos de categorias clínicas do $\mathrm{CDC}$, utilizando-se o teste não paramétrico de MannWhitney, uma vez que os escores podem não apresentar distribuição Normal. Espera-se que as crianças/adolescentes com as piores categorias clínico imunológicas tenham uma pior qualidade de vida quando comparadas com aquelas com as melhores. São esperadas diferenças nos domínios de qualidade de vida, principalmente naquele de Sintomas ou Sinais.

\section{Grupos de comparação:}

$\mathrm{Na}$ faixa etária de 6 meses a 4 anos foram considerados como não doentes as crianças expostas ao HIV e doentes aquelas com o diagnóstico de infecção pelo HIV nas categorias $\mathrm{N}$ (assintomática), A (sinais/sintomas leves) e B (sinais/sintomas moderados).

$\mathrm{Na}$ faixa de 5 a 11 anos e também na de 12 a 20 anos, foram considerados como não doentes as crianças/adolescentes nas categorias clínicas $\mathrm{N}$ (assintomática) e $\mathrm{A}$ 
(sinais/sintomas leves) e doentes as crianças nas categorias B (sinais/sintomas moderados) e C (Sintomas ou Sinais graves).

Nas faixas de 5 a 11 anos e de 12 a 20 anos utilizou-se ponto de corte diferente da faixa de 6 meses a 4 anos, pois as duas faixas etárias mais velhas não apresentam crianças expostas.

Para a análise da comparação de médias foi calculado o poder do teste estatístico, pois a distribuição de freqüência nos grupos de comparação foi pequena.

2) Foi calculado o coeficiente de correlação de Spearman entre os escores de qualidade de vida e marcadores clínicos - contagem de células de defesa CD4 e carga viral. Também foi calculado o mesmo coeficiente entre os escores e marcadores de Utilização dos Serviços de Saúde - número de noites passadas no hospital e número de visitas ao serviço médico no último mês -, segundo faixa etária. Espera-se que as crianças/adolescentes com melhores níveis de CD4 tenham melhores escores de qualidade de vida em todos os domínios (relação linear positiva). Espera-se, também, que as crianças/adolescentes com os piores níveis de carga viral (aumento da carga viral) tenham piores escores de qualidade de vida (relação linear negativa).

\subsection{Auto-Eficácia}

Para a validação do questionário de auto-eficácia foram utilizadas as seguintes estratégias:

1) Foi realizada a comparação dos dois escores de auto-eficácia entre grupos de crianças/adolescentes aderentes e não aderentes ao tratamento anti-retroviral, por faixa etária e total da amostra, utilizando o teste de Mann-Whitney.

2) Foi calculado o coeficiente de correlação de Spearman entre os escores 1 e 2 de $\mathrm{AE}$ e os marcadores clínicos - contagem de células de defesa CD4 e carga viral. Espera-se, também, que as crianças/adolescentes com melhores níveis de CD4 tenham melhores escores 1 e 2 de auto-eficácia (relação linear positiva) e que as 
crianças/adolescentes com os maiores níveis de carga viral (aumento da carga viral) tenham piores escores de auto-eficácia (relação linear negativa).

\subsubsection{Reprodutibilidade (teste-reteste)}

Reprodutibilidade pode ser entendida como a reprodução (reproducible) dos resultados de uma escala em diferentes ocasiões, ou por diferentes observadores (STREINER e NORMAN, 2003). Segundo PEREIRA (1995a) espera-se que os resultados sejam similares (estáveis), mantidas as mesmas condições.

No retorno do paciente ao serviço, que levou de 30 a 45 dias, foram aplicados, novamente, os questionários de qualidade de vida e da auto-eficácia, afim de se avaliar a estabilidade dos instrumentos.

Do total de 90 pacientes inicialmente entrevistados, foram feitas 60 reaplicações dos questionários (66,7\%). As 30 entrevistas restantes não puderam ser concluídas, pois os pacientes não atenderam as convocações. Quando o paciente incorre em falta e não avisa para remarcar, a assistente social do serviço entra em contato (telefônico, ou via telegrama, pois muitos dos pais/responsáveis não autorizavam contato telefônico). Mesmo assim, decidiu-se finalizar esta pesquisa no final de setembro de 2005, pois o retorno nas convocações foi baixo.

$\mathrm{Na}$ análise da reprodutibilidade dos questionários comparou-se as médias dos escores nos dois momentos da pesquisa (teste-reteste) utilizando o teste de Wilcoxon, verificou-se a relação entre os escores (teste-reteste) pelo coeficiente de correlação intraclasse e verificou-se a concordância entre os escores (teste-reteste) pelo método de Bland-Altman (BLAND e ALTMAN, 1986).

O método de BLAND e ALTMAN (1986) baseia-se em uma técnica gráfica onde as diferenças pontuais entre os escores de duas medidas (no caso, teste-reteste) são comparadas com a média das diferenças, em um gráfico. Como não se tem, ou não se sabe os valores verdadeiros das diferenças, a diferença média, segundo, os autores é a melhor estimativa para a diferença. Se não existem vieses, espera-se que não exista 
relação entre as estimativas das diferenças e a sua média e uma distribuição aleatória das diferenças em torno da média. Diante desta circunstância, se as diferenças são Normalmente distribuídas, $95 \%$ das diferenças permanecerão entre os chamados “ limites de concordância" ( $\bar{d}-1,96 s$ e $\bar{d}+1,96 s)$, onde $\bar{d}$ é a média das diferenças e $s$ é o desvio-padrão das diferenças. Espera-se que as diferenças sigam uma distribuição Normal, pois foram removidas a maior parte das variações entre os indivíduos e o que sobram são os erros de mensuração (medidas)

\subsection{PROGRAMAS DE COMPUTADOR (SOFTWARES)}

- Epi-Info versão 6.04 para DOS: digitação, consistência dos dados (validate) e análise descritiva dos dados;

- SPSS versão 10.0: cálculo do $\alpha$ de Cronbach, análise fatorial, coeficientes de correlação e testes de diferenças de médias, gráficos.

- MedCalc versão 7.2.0.2: gráficos de Bland Altman.

- Lisrel versão 8.80: análise fatorial.

- Statistica versão 6.0: cálculo do poder do teste.

\subsection{ASPECTOS ÉTICOS}

Garantiu-se o caráter voluntário do participante no estudo. Os pais ou cuidadores das crianças que aceitaram participar da pesquisa assinaram o termo de consentimento livre e esclarecido, no qual está explicado a finalidade da pesquisa e os procedimentos da avaliação da qualidade de vida (Anexo 1).

Este projeto foi aprovado pelo Comitê de Ética em Pesquisa da Faculdade de Saúde Pública da Universidade de São Paulo (COEP-FSP) (Anexo 14) e pela Comissão de Ética do Centro de Referência e Treinamento em DST/Aids (Anexo 15). 
Podem ter ocorrido alguns desconfortos frente a algumas questões para pacientes e familiares; no entanto, foi oferecido constantemente suporte psicológico continuado pela equipe do CRT.

O banco de dados bem como os questionários que deram origem a pesquisa estão devidamente arquivados na Faculdade de Saúde Pública. 


\section{RESULTADOS}

\subsection{TRADUÇÃO}

\subsubsection{Avaliação da Equivalência Conceitual e de Itens do Questionário de Qualidade de Vida}

De acordo com as discussões entre os três pesquisadores foi verificado que os itens que compõem o instrumento original de qualidade de vida representam adequadamente as dimensões da qualidade de vida no contexto cultural brasileiro. Algumas modificações foram feitas e incorporadas à versão final em português.

$\mathrm{Na}$ Seção Clínica de todos os questionários retirou-se duas questões não pertinentes para os pacientes no Brasil. Uma delas pergunta se os pais/responsáveis assinaram a ordem de não reanimar (DNR). A outra pergunta se o paciente esteve sob cuidados terminais, cujo termo utilizado na língua Inglesa foi "Hospice Care", que diz respeito a instituições destinadas para pessoas com doenças incuráveis, o que não é disponível no Brasil.

Ainda na Seção Clínica, na questão que pergunta a língua em que o questionário foi administrado, incluiu-se a opção Português, que não havia.

No domínio Utilização de Serviços de Saúde, na parte dos tratamentos alternativos de saúde, acrescentamos dois itens: "Homeopatia" e "Outros Tratamentos (Quais?)".

No questionário para a faixa etária de 6 meses a 4 anos, no domínio Avaliação das Atividades Pessoais e Sociais, na questão sobre quem cuidou da criança na maior parte do tempo durante os dias da semana, adaptou-se os seguintes os itens:

- Item 18: "A Head Start Program" foi alterado para Casa de Apoio;

- Item 19: "Early Intervencion Program" para Programa de estimulação precoce; 
- Item 20: "Special Education Program" para Outra pessoa e

- Item 21: "Someone else" para Outros parentes.

No questionário para a faixa de 5 a 11 anos, no domínio das Atividades Pessoais e Sociais, na questão sobre o grau de escolaridade foram feitas adaptações levando-se em conta as séries do ensino fundamental no Brasil. Para tanto incluiu-se o item 20 que é a $8^{a}$ série do ensino fundamental, pois na versão em Inglês o grau de escolaridade máximo nessa faixa etária era " $7^{\text {th }}$ Grade". Ainda nesse domínio, retirou-se uma pergunta referente ao fato da criança estudar em casa (não freqüentar a escola), pois essa modalidade não ocorre no Brasil.

No questionário para as crianças/adolescentes de 12 a 20 anos, no domínio das Atividades Pessoais e Sociais, também foram feitas adaptações na questão do grau de escolaridade. Assim, na versão deixou-se como grau mínimo de escolaridade a $1^{\text {a }}$ série do ensino fundamental e como grau máximo o $6^{\circ}$ ano universitário.

\subsubsection{Avaliação da Equivalência Semântica}

$\mathrm{Na}$ etapa da retradução foi verificada, de uma maneira geral, uma boa equivalência dos itens da retradução, quando comparados com os do instrumento original.

$\mathrm{Na}$ terceira etapa da avaliação (comparação da versão final em inglês e a original), identificou-se que as discrepâncias ocorridas entre os itens eram relativas tanto ao significado referencial quanto ao significado geral. Os itens discrepantes foram modificados e foi finalizada a versão em português.

A expressão "jail sentence" nos Estados Unidos significa "prisão" enquanto que no Brasil pode ser tanto "detenção" como "prisão". Na versão final em português foi deixada como "prisãoldetenção".

O significado da palavra "stepbrother/stepsister" foi traduzido como “irmão/irmã adotivo". Verificou-se que este termo, em inglês, é mais amplo e abrange os filhos adotivos e os filhos de outros casamentos, enquanto que em português não 
existe uma única palavra para descrever os filhos de outros casamentos dos pais, sem vínculos biológicos. Optou-se por deixar, na versão em português "irmã/irmão adotivos" ou "filhos de outros casamentos dos pais" (sem vínculo biológico).

Para a expressão "my child is easily confused, seems to be in a fog" verificou-se que não há tradução para o português no sentido literal. Fez-se uma adaptação de linguagem para: "Minha criança se confunde facilmente, parece estar um pouco fora do ar ou no mundo da lua".

A palavra "bullie" foi traduzida como "valente" na primeira versão; entretanto, nos Estados Unidos, "bullie" não implica valentia no sentido de coragem como foi traduzida, mas no sentido de agressividade e por isso escolheu-se, para a versão final, a palavra "intimidador" para substituir a palavra "valente".

No quadro 7 estão listadas as principais questões que foram modificadas.

Quadro 7: Resumo de exemplo das expressões em inglês.

\begin{tabular}{|c|c|c|}
\hline $\begin{array}{c}\text { Expressão em } \\
\text { inglês }\end{array}$ & Idéia inicial & Resultado final da tradução \\
\hline Jail sentence & Prisão & Detenção/prisão \\
\hline $\begin{array}{l}\text { Stepbrother } \\
\text { Stepsister }\end{array}$ & $\begin{array}{l}\text { Irmão adotivo } \\
\text { Irmã adotiva }\end{array}$ & $\begin{array}{l}\text { Irmão/irmã de outros casamentos } \\
\text { dos pais, sem vínculo biológico }\end{array}$ \\
\hline $\begin{array}{l}\text { My child is easily } \\
\text { confused, seems } \\
\text { to be in a fog }\end{array}$ & Não há tradução literal & $\begin{array}{l}\text { Minha criança se confunde } \\
\text { facilmente, parece } \\
\text { estar um pouco fora do ar ou no } \\
\text { mundo da lua. }\end{array}$ \\
\hline Bully & Valente & Intimidador \\
\hline
\end{tabular}




\subsection{CARACTERIZAÇÃO DA AMOSTRA}

Mais de $85 \%$ das pessoas que responderam à pesquisa foram os pais (pai/mãe, pais adotivos) sendo que $71,2 \%$ deles eram as próprias mães (biológicas ou adotivas) e as categorias avós, tios, irmãos também apareceram em proporções menores. Foram entrevistados três adolescentes maiores de 18 anos desacompanhados de cuidadores/pais/responsáveis legais. A maior parte $(83,3 \%)$ dos respondentes era do sexo feminino e poucos tinham até 30 anos $(21,1 \%)$. Cerca de $30 \%$ não possui renda $e$ apenas $26,7 \%$ têm renda superior a $\mathrm{R} \$ 600,00$. Verificou-se que $53,0 \%$ desses cuidadores cursaram o ensino fundamental (Tabela 1).

Tabela 1: Número e porcentagem de crianças e adolescentes segundo características do respondente. CRT/SP, março 2005.

\begin{tabular}{|c|c|c|c|}
\hline Variável & Categoria & $\mathbf{N}^{\circ}$ & $\%$ \\
\hline \multirow{6}{*}{ Pessoa } & Avó/avô & 5 & 5,6 \\
\hline & Irmã & 1 & 1,1 \\
\hline & Mãe & 64 & 71,2 \\
\hline & Pai & 13 & 14,4 \\
\hline & Tia/tio & 4 & 4,4 \\
\hline & Adolescente maior de 18 & 3 & 3,3 \\
\hline \multirow[t]{2}{*}{ Sexo } & Masculino & 15 & 16,7 \\
\hline & Feminino & 75 & 83,3 \\
\hline \multirow[t]{3}{*}{ Idade (anos) } & $19-30$ & 19 & 21,1 \\
\hline & $31-39$ & 33 & 36,7 \\
\hline & $40-73$ & 38 & 42,2 \\
\hline \multirow[t]{5}{*}{ Escolaridade } & Não estudou & 4 & 4,4 \\
\hline & $1^{\mathrm{a}}-4^{\mathrm{a}}$ série ensino fundamental & 11 & 12,2 \\
\hline & $5^{\mathrm{a}}-8^{\mathrm{a}}$ série ensino fundamental & 37 & 41,1 \\
\hline & Ensino médio (in) completo & 33 & 36,7 \\
\hline & Ensino superior (in) completo & 5 & 5,6 \\
\hline \multirow[t]{5}{*}{ Renda } & Não tem & 26 & 28,9 \\
\hline & Até $\mathbf{R} \$ \mathbf{3 0 0 , 0 0}$ & 19 & 21,1 \\
\hline & $R \$ 301,00-600,00$ & 16 & 17,8 \\
\hline & $R \$ 601,00-2700,00$ & 24 & 26,7 \\
\hline & Ignorado & 5 & 5,5 \\
\hline Total & & 90 & 100,0 \\
\hline
\end{tabular}


A maioria das crianças e adolescentes que participou do estudo era do sexo feminino $(57,8 \%)$ e tinha cor da pele branca $(61,1 \%)$. As proporções de crianças nas faixas etárias de 6 meses a 4 anos e 5 a 11 anos foram iguais $(38,9)$, sendo que a faixa de 12 a 20 anos contou com uma proporção um pouco menor $(22,2 \%)$. A metade das crianças/adolescentes está cursando o ensino fundamental e 43,3\% delas ou não estudam ou ainda estão no berçário/maternal/jardim/pré-escola (Tabela 2).

Tabela 2: Número e porcentagem de pacientes segundo características sóciodemográficas e clínicas das crianças e adolescentes. CRT/SP, março 2005.

\begin{tabular}{l|l|rr}
\hline Variável & Categoria & $\mathbf{N}^{\circ}$ & \% \\
\hline Sexo & Masculino & 38 & 42,2 \\
& Feminino & 52 & 57,8 \\
Cor da pele & Branco & 55 & 61,1 \\
& Não branco & 35 & 38,9 \\
Idade (meses) & $6-59$ & & \\
& $60-143$ & 35 & 38,9 \\
& $144-251$ & 35 & 38,9 \\
Escolaridade & & 20 & 22,2 \\
& Não estuda & 27 & 30,0 \\
& Berçário/maternal/pré-escola & 10 & 11,1 \\
& Jardim & 2 & 2,2 \\
& $1^{\mathrm{a}}-4^{\mathrm{a}}$ série ensino fundamental & 29 & 32,2 \\
& $5^{\mathrm{a}}-8^{\mathrm{a}}$ série ensino fundamental & 16 & 17,8 \\
& $1^{\mathrm{a}}-3^{\mathrm{a}}$ ensino médio & 6 & 6,7 \\
\hline & & & $\mathbf{9 0}$ \\
\hline Total & & & $\mathbf{1 0 0 , 0}$ \\
\hline
\end{tabular}


Mais de $50 \%$ das crianças/adolescentes ingressaram no CRT/SP no período de 2001 a 2005 e tiveram diagnóstico nesse mesmo período. Quase todos os pacientes tiveram transmissão vertical, em 4 foi indeterminado e para um paciente esta informação não consta do prontuário. Mais de $50 \%$ da amostra tem as categorias clínicas B e C. Verifica-se, também, que mais de $60 \%$ das crianças/adolescentes estão tomando os medicamentos anti-retrovirais e que a maioria deles não recebeu a profilaxia para transmissão vertical (PACTG076) (Tabela 3).

Tabela 3: Número e porcentagem de crianças e adolescentes segundo características clínicas. CRT/SP, março 2005.

\begin{tabular}{l|l|rr}
\hline Variável & Categoria & $\mathbf{N}^{\circ}$ & \% \\
\hline Ano no CRT/Aids & $1989-1995$ & 10 & 11,1 \\
& $1996-2000$ & 33 & 36,7 \\
& $2001-2005$ & 46 & 51,1 \\
Ano do diagnóstico & Ignorado & 1 & 1,1 \\
& $1989-1995$ & 11 & 12,2 \\
& $1996-2000$ & 26 & 28,9 \\
Classe CDC atual & $2001-2005$ & 51 & 56,7 \\
& ignorado & 2 & 2,2 \\
& Exposto & 31 & 34,5 \\
& N (assintomática) & 4 & 4,4 \\
Alteração imunológica & A (sinais/sintomas leves) & 6 & 6,7 \\
n=55 & B (sinais/sintomas moderados) & 27 & 30,0 \\
& C (sinais/sintomas graves) & 22 & 24,4 \\
Droga ARV & Ausente & 9 & 16,4 \\
& Moderado & 26 & 47,2 \\
PACTG076 & Grave & 20 & 36,4 \\
& Sim & 54 & 60,0 \\
& Não & 36 & 40,0 \\
Esquema de Resgate & Incompleto & 12 & 13,3 \\
n=59 & Sim & 26 & 28,9 \\
& Não & 52 & 57,8 \\
Total & Sim & 18 & 30,5 \\
\hline & Não & 41 & 69,5 \\
& & & \\
\hline & & 90 & 100,0 \\
\hline
\end{tabular}




\title{
4.3 QUESTIONÁRIO DE QUALIDADE DE VIDA
}

\author{
4.3.1 Faixa Etária de 6 meses a 4 anos
}

\subsubsection{Avaliação da Equivalência de Mensuração}

\subsection{Consistência Interna}

A análise descritiva e da consistência interna para a faixa etária de 6 meses a 4 anos está na Tabela 4. As tabelas que mostram a distribuição de freqüências para cada questão do questionário de qualidade de vida estão no Anexo 16.

O domínio que apresentou a melhor consistência interna foi o de Sintomas ou Sinais. Os demais domínios apresentaram consistência interna entre 0,10 e 0,50 , com exceção do domínio de Atividades Pessoais e Sociais que apresentou um valor negativo para o a Cronbach.

Os escores de todos os domínios tiveram aderência à curva Normal, com exceção do domínio das Atividades Pessoais e Sociais $(\mathrm{p}<0,001)$. 
Tabela 4: Análise descritiva e da consistência interna do questionário de qualidade de vida para a faixa etária de 6 meses a 4 anos. CRT/SP, março 2005.

\begin{tabular}{|c|c|c|c|c|c|c|}
\hline \multirow[b]{2}{*}{ Parâmetro } & \multirow[b]{2}{*}{$\begin{array}{l}\text { Avaliação Geral } \\
\text { da Saúde }\end{array}$} & \multirow[b]{2}{*}{$\begin{array}{l}\text { Resistência } \\
\text { Física }\end{array}$} & \multicolumn{2}{|c|}{ Domínio - 6 meses a 4 anos $(n=35)$} & \multirow[b]{2}{*}{$\begin{array}{l}\text { Utilização dos } \\
\text { Serviços de } \\
\text { Saúde } \\
\end{array}$} & \multirow[b]{2}{*}{$\begin{array}{l}\text { Sintomas ou } \\
\text { Sinais }\end{array}$} \\
\hline & & & Estado Físico & $\begin{array}{l}\text { Atividades } \\
\text { Pessoais e } \\
\text { Sociais }\end{array}$ & & \\
\hline média (dp) & $88,15(10,99)$ & $83,47(13,62)$ & $81,73(10,39)$ & $83,43(16,26)$ & $87,69(7,51)$ & $90,37(8,50)$ \\
\hline Mediana & 88,89 & 85,71 & 82,14 & 90,00 & 88,46 & 93,00 \\
\hline $\min -\max$ & $59,26-100,00$ & $57,14-100,00$ & $60,71-100,00$ & $20,00-100,00$ & $65,38-100,00$ & $70,00-100,00$ \\
\hline$\alpha$ Cronbach & 0,41 & 0,10 & $\mathbf{0 , 3 0}$ & \# & $\mathbf{0 , 5 0}$ & $\mathbf{0 , 7 8}$ \\
\hline
\end{tabular}

\#: O valor do $\alpha$ Cronbach foi negativo. 


\subsection{Análise Fatorial Confirmatória}

Na Tabela 5 mostra os resultados da análise fatorial confirmatória. Para o domínio de Avaliação Geral da Saúde foi definido um único fator que explicou $68,45 \%$ da variância total. Duas das três questões que compõem este domínio foram as que mais contribuíram para este fator (maiores cargas fatoriais) - "Como a criança vem se sentindo de maneira geral" e "fisicamente". A questão " Como a criança tem se sentido emocionalmente" apresentou uma carga fatorial mais baixa quando comparada com as duas questões acima.

Para o domínio de Resistência Física foi definido um único fator que explicou $38,25 \%$ da variância. Foram confirmadas neste fator, quatro das sete questões que fazem parte deste domínio, sendo que as questões que mais contribuíram foram “ Minha criança é bastante suscetível a doenças que estão circulando", “Minha criança é pouco desajeitada" e "Minha criança parece ter uma tendência a sofrer acidentes".

Em relação ao Estado Físico, foi definido um único fator que explicou $42,11 \%$ da variäncia total. Foram confirmadas neste fator cinco das quinze questões que originalmente compõem este domínio. As questões que apresentaram maiores cargas fatoriais neste domínio foram "Muda de humor sem razão aparente", "Parece mais difícil de lidar do que de costume" e "Reage com choro a pequenas coisas".

No domínio das Atividades Pessoais e Sociais, o único fator definido na análise explicou 76,21\% da variância dos dados. Foram confirmadas neste fator, uma questão da parte A deste domínio (que é um escore de 1 a 6) e três questões da parte B, com respostas do tipo sim e não. Todas as questões apresentaram cargas fatoriais altas neste fator.

Para o domínio de Utilização dos Serviços de Saúde, a solução fatorial de um único fator explicou $46,98 \%$ da variância total. Foram confirmadas quatro questões da parte B deste domínio para o fator. Das questões referentes ao uso de medicação, "medicamento para dor", "medicamentos para resfriado" e "cremes, pomadas para lesões, feridas" foram as que mais contribuíram para o fator. 
No domínio de Sintomas ou Sinais, nove questões de um total de vinte foram confirmadas no único fator que explicou $91,47 \%$ da variância total. Todas as questões contribuíram com cargas fatoriais altas para a formação do fator. 
Tabela 5: Resultados da análise fatorial confirmatória dos domínios do questionário de qualidade de vida para a faixa etária de 6 meses a 4 anos. CRT/SP, março 2005.

\begin{tabular}{|c|c|c|c|}
\hline Questões & Fator 1 & Variância & Uniqueness \\
\hline \multicolumn{4}{|l|}{ Avaliação Geral da Saúde } \\
\hline 1. De maneira geral & 0,997 & 0,994 & 0,007 \\
\hline 2. Fisicamente & 0,997 & 0,994 & 0,007 \\
\hline \multirow[t]{2}{*}{ 3. Emocionalmente } & 0,259 & 0,067 & 0,933 \\
\hline & & 2,055 & 0,947 \\
\hline Variância total & & \multicolumn{2}{|c|}{3,002} \\
\hline \% variância explicada & & $68,45 \%$ & \\
\hline \multicolumn{4}{|l|}{ Resistência Física } \\
\hline 3. Minha criança parece menos sadia do que as outras crianças que eu conheço & $-0,294$ & 0,086 & 0,913 \\
\hline 4. Minha criança é bastante suscetível a doenças que estão circulando & 0,575 & 0,330 & 0,669 \\
\hline 5. Minha criança é pouco desajeitada & 0,636 & 0,404 & 0,595 \\
\hline 6. Minha criança parece ter uma tendência a sofrer acidentes & 0,842 & 0,709 & 0,291 \\
\hline & & 1,529 & 2,468 \\
\hline Variância total & & \multicolumn{2}{|c|}{3,997} \\
\hline \% variância explicada & & $38,25 \%$ & \\
\hline \multicolumn{4}{|l|}{ Avaliação do Estado Físico } \\
\hline 4. Muda de humor sem razão aparente & 0,791 & 0,625 & 0,374 \\
\hline 7. Se ocupa fazendo coisas, brincando sozinha & 0,071 & 0,005 & 0,995 \\
\hline 10. Dorme a noite toda & $-0,078$ & 0,006 & 0,994 \\
\hline 12. Parece estar mais difícil de lidar do que o costume & 0,932 & 0,869 & 0,131 \\
\hline 14. Reage com choro a pequenas coisas & 0,775 & 0,600 & 0,400 \\
\hline & & 2,105 & 2,894 \\
\hline Variância total & & \multicolumn{2}{|c|}{4,999} \\
\hline \% variância explicada & & $42,11 \%$ & \\
\hline \multicolumn{4}{|l|}{ Avaliação das Atividades Pessoais e Sociais } \\
\hline $\begin{array}{l}\text { 1. A sua criança ficou na cama (a maioria do tempo ou durante todo o dia) devido a alguma doença ou } \\
\text { lesão/ferimento/acidente/machucado }\end{array}$ & $-0,988$ & 0,976 & 0,023 \\
\hline $\begin{array}{l}\text { 3. Ssua criança teve alguma doença ou lesão que limitou ou impediu que ela fizesse alguma das atividades infantis tais como } \\
\text { brincar com outras crianças ou participar de jogos e esportes }\end{array}$ & 0,908 & 0,824 & 0,175 \\
\hline 4. No geral, sua criança esteve capaz de participar das atividades rotineiras com as outras crianças & 0,905 & 0,819 & 0,181 \\
\hline 5. No geral, sua criança esteve limitada no tipo de brincadeira devido à sua saúde? & 0,654 & 0,428 & 0,572 \\
\hline & & 3,047 & 0,951 \\
\hline Variância total & & \multicolumn{2}{|c|}{3,998} \\
\hline \% variância explicada & & $76,21 \%$ & \\
\hline
\end{tabular}




\begin{tabular}{|c|c|c|c|}
\hline Questões & Fator 1 & Variância & Uniqueness \\
\hline \multicolumn{4}{|l|}{ Utilizacão dos Servicos de Saúde } \\
\hline 6. medicamento para a dor & 0,997 & 0,994 & 0,007 \\
\hline 7. antibióticos & 0,227 & 0,052 & 0,948 \\
\hline 8. medicamentos para resfriado & 0,773 & 0,598 & 0,403 \\
\hline \multirow{2}{*}{ 10. cremes, pomadas para lesões, feridas } & 0,486 & 0,236 & 0,764 \\
\hline & & 1,880 & 2,122 \\
\hline Variância total & & \multicolumn{2}{|c|}{4,002} \\
\hline \% variância explicada & & $46,98 \%$ & \\
\hline \multicolumn{4}{|l|}{ Sintomas ou Sinais } \\
\hline 2. chiado, tosse & 0,997 & 0,994 & 0,007 \\
\hline 5. manchas, coceiras ou outros problemas de pele & 0,997 & 0,994 & 0,007 \\
\hline 8. febre, suores noturnos, tremores e calafrios & 0,997 & 0,994 & 0,007 \\
\hline 9. perda de apetite & 0,997 & 0,994 & 0,007 \\
\hline 10. problemas de sono & 0,997 & 0,994 & 0,007 \\
\hline 15. dificuldade para respirar ou pegar o ar & 0,997 & 0,994 & 0,007 \\
\hline 16. nariz escorrendo ou problemas de sinusite & 0,537 & 0,288 & 0,712 \\
\hline 19. dor de ouvido & $-0,997$ & 0,994 & 0,007 \\
\hline \multirow[t]{2}{*}{ 20. desconforto ou mal estar geral } & 0,997 & 0,994 & 0,007 \\
\hline & & 8,240 & 0,768 \\
\hline Variância total & & \multicolumn{2}{|c|}{9,008} \\
\hline \% variância explicada & & $91,47 \%$ & \\
\hline
\end{tabular}




\subsection{Validação}

\section{Validade de Constructo}

\section{Comparação de médias}

A Tabela 6 mostra a comparação das médias dos escores de qualidade de vida entre as categorias clínicas do CDC, para a faixa etária de 6 meses a 4 anos.

$\mathrm{Na}$ faixa etária de 6 meses a 4 anos, houve diferença estatisticamente significativa nas médias do escore de Estado Físico entre o grupo de crianças expostas quando comparado com aquele de crianças infectadas pelo HIV (83,29 x 69,64; $\mathrm{p}=0,009$ ). Nos demais domínios não foi realizado o teste por falta de poder estatístico.

Tabela 6: Comparação de médias dos domínios da faixa etária de 6 meses a 4 anos em relação às categorias do CDC. CRT/SP, março 2005.

\begin{tabular}{|c|c|c|c|c|}
\hline \multirow[t]{2}{*}{ Domínio } & \multicolumn{4}{|c|}{6 meses a 4 anos } \\
\hline & $\begin{array}{l}\text { Não doente } \\
\mathrm{n=31}\end{array}$ & $\begin{array}{l}\text { Doente } \\
\mathrm{n}=4 \\
\text { p) }\end{array}$ & $\mathbf{p}^{*}$ & $\begin{array}{l}\text { Poder } \\
\text { do } \\
\text { teste }\end{array}$ \\
\hline Avaliação Geral da Saúde & $88,77(11,05)$ & $83,33(10,70)$ & $\mathrm{nr}$ & 0,20 \\
\hline Resistência Física & $83,41(13,85)$ & $83,93(13,52)$ & $\mathrm{nr}$ & 0,05 \\
\hline Estado Físico & $83,29(9,95)$ & $69,64(3,57)$ & 0,009 & - \\
\hline Atividades Pessoais e Sociais & $82,58(17,12)$ & $90,00(0)$ & $\mathrm{nr}$ & - \\
\hline Utilização Serviços de Saúde & $87,35(7,77)$ & $90,38(4,97)$ & $\mathrm{nr}$ & 0,15 \\
\hline Sintomas ou Sinais & $91,32(7,94)$ & $83,00(10,30)$ & $\mathrm{nr}$ & 0,40 \\
\hline
\end{tabular}

p*: Teste de Mann-Whitney

${ }^{1}$ Não-doente: crianças expostas; Doente: categorias $\mathrm{N}+\mathrm{B}$;

nr: não realizado. 


\section{Correlação com contagem de células de defesa CD4 e carga viral}

Os escores dos domínios foram correlacionados com a contagem de células de defesa CD4 e carga viral, analisadas com a transformação logarítmica. Mesmo tendo somente 4 pacientes com infecção pelo HIV no grupo de 6 meses a 4 anos, foi estimado o coeficiente de correlação de Spearman entre os escores dos domínios e as características clínicas dessas crianças. Espera-se, nessa análise que quanto maior o CD4, melhores sejam os escores de qualidade de vida (correlação positiva) e quanto maior a carga viral, menores os escores de qualidade de vida (correlação negativa).

$\mathrm{Na}$ faixa etária de 6 meses a 4 anos houve forte correlação negativa entre Sintomas ou Sinais e carga viral $(r=-1,00 ; p<0,001)$ e também entre Resistência Física $e$ carga viral $(r=-1,00 ; p<0,001)$. Obteve-se também coeficiente de correlação negativo e superior a 0,30 entre carga viral e Avaliação Geral da Saúde e entre carga viral e Utilização dos Serviços de Saúde, mostrando que com o aumento da carga viral há uma piora nos escores de qualidade de vida de um modo geral. Não foi possível calcular o coeficiente de correlação entre carga viral e Estado Físico e entre carga viral e Atividades Pessoais e Sociais uma vez que os escores nesses domínios foram constantes. Mesmo não sendo significativos, os coeficientes de correlação entre CD4 e Resistência Física (correlação negativa), CD4 e Utilização dos Serviços de Saúde (correlação positiva) e entre CD4 e sintomas foram superiores a 0,30 (correlação negativa). Essas correlações negativas entre CD4 e Resistência Física e entre CD4 e Sintomas ou Sinais não eram esperadas, mas, por conta de uma criança com contagem de CD4 alta (CD4=2.035 células $/ \mathrm{mm}^{3}$ ) e escores de qualidade de vida baixo nesses domínios, obteve-se um sinal inverso na correlação. Não foi possível calcular o coeficiente de correlação entre CD4 e Atividades Pessoais e Sociais, pois os escores da amostra foram constantes nesse domínio (Tabela 7). 
Tabela 7: Coeficiente de correlação de Spearman (r) entre os escores dos diferentes domínios e a contagem de célula de defesa CD4 e Carga Viral para a faixa etária de 6 meses a 4 anos. CRT/SP, março 2005.

\begin{tabular}{|c|c|c|}
\hline \multirow[t]{2}{*}{ Domínio } & \multicolumn{2}{|c|}{6 meses a 4 anos $(n=4)$} \\
\hline & $\frac{C D 4}{r(p)}$ & $\frac{\text { Carga Viral }}{\mathbf{r}(\mathbf{p})}$ \\
\hline Avaliação Geral da Saúde & $0,20(0,800)$ & $-0,50(0,667)$ \\
\hline Resistência Física & $-0,31(0,684)$ & $-1,00(<0,001)$ \\
\hline Estado Físico & $-0,26(0,742)$ & - \\
\hline Atividades Pessoais e Sociais & - & - \\
\hline Utilização Serviços de Saúde & $0,40(0,600)$ & $-0,50(0,667)$ \\
\hline Sintomas ou Sinais & $-0,40(0,600)$ & $-1,00(0,001)$ \\
\hline
\end{tabular}




\section{Correlação com a Utilização dos Serviços de Saúde}

Os escores dos domínios do questionário de qualidade de vida também foram correlacionados com as noites passadas no hospital nas 4 últimas semanas e visitas ao serviço de saúde também no mesmo período, sendo estas marcadoras da utilização de serviços de saúde.

Na faixa etária de 6 meses a 4 anos todas as correlações entre os escores dos domínios e noites passadas no hospital e também entre os domínios e visitas ao serviço médico nas últimas 4 semanas foram negativas, mostrando que quanto maior o número de noites no hospital e também maior o número de consultas, piores são os escores de qualidade de vida (Tabela 8). Obteve-se coeficiente de correlação negativo e acima de 0,30 entre as noites passadas no hospital e o escore do domínio de Atividades Pessoais e Sociais, sendo que essa correlação ficou no limite da significância estatística ( $r=-0,33$; $\mathrm{p}=0,052$ ). Em relação às visitas ao serviço médico, as correlações foram negativas, maiores que 0,30 e estatisticamente significativas nos domínios de Resistência Física ( $r=-0,37 ; p=0,031)$ e Utilização dos Serviços de Saúde $(r=-0,45 ; p=0,007)$, o que era esperado, pois se há um aumento no número de visitas espera-se uma piora no escore de Resistência Física e também uma piora no escore de Utilização dos Serviços de Saúde (Tabela 8). 
Tabela 8: Coeficientes de correlação de Spearman (r) entre os escores dos diferentes domínios e marcadores de Utilização dos Serviços de Saúde - noites no hospital e visitas ao médico no último mês para a faixa etária de 6 meses a 4 anos. CRT/SP, março 2005.

\begin{tabular}{|c|c|c|}
\hline \multirow{2}{*}{ Dominio } & \multicolumn{2}{|c|}{6 meses a 4 anos $(n=35)$} \\
\hline & $\frac{\text { Noites }}{r(\mathrm{D})}$ & $\frac{V i s i t n s}{r(D)}$ \\
\hline Avaliação Geral da Saúde & $-0,29(0,088)$ & $-0,21(0,228)$ \\
\hline Resistência Física & $-0,28(0,107)$ & $-0,37(0,031)$ \\
\hline Estado Físico & $-0,08(0,660)$ & $-0,16(0,372)$ \\
\hline Atividades Pessoais e Sociais & $-0,33(0,052)$ & $-0,17(0,341)$ \\
\hline Utilização Serviços de Saúde & $-0,26(0,130)$ & $-0,45(0,007)$ \\
\hline Sintomas ou Sinais & $-0,21(0,219)$ & $-0,24(0,158)$ \\
\hline
\end{tabular}




\subsection{Reprodutibilidade}

A Tabela 9 apresenta os resultados da comparação entre o teste e o reteste. Verifica-se que na faixa de 6 meses a 4 anos não houve diferença estatisticamente significativa nas médias dos escores dos domínios, quando se considera os dois momentos. Os domínios que tiveram correlação intra-classe significativos foram os de Resistência Física, Estado Físico e Sintomas ou Sinais.

Tabela 9: Comparação teste-reteste entre os escores nos domínios e faixa etária de 6 meses a 4 anos e coeficientes de correlação intraclasse ( $\left.r_{\text {icc }}\right)$. CRT/SP, março 2005.

\begin{tabular}{|c|c|c|c|c|c|}
\hline \multirow[b]{2}{*}{ Domínio } & \multicolumn{5}{|c|}{6 meses a 4 anos $(n=17)$} \\
\hline & Teste & $\frac{\text { Reteste }}{(d p)}$ & $\mathbf{p}$ & rice & $\mathbf{p}$ \\
\hline Avaliação Geral da Saúde & $86,3(10,8)$ & $87,1(14,8)$ & 0,800 & 0,44 & 0,076 \\
\hline Resistência Física & $85,7(12,1)$ & $84,9(14,3)$ & 0,727 & 0,74 & 0,001 \\
\hline Estado Físico & $80,3(10,2)$ & $79,2(10,7)$ & 0,584 & 0,72 & 0,001 \\
\hline Atividades Pessoais e Sociais & $84,1(17,7)$ & $83,5(14,6)$ & 0,915 & 0,04 & 0,888 \\
\hline Utilização Serviços de Saúde & $88,9(5,2)$ & $90,0(9,7)$ & 0,713 & $-0,32$ & 0,206 \\
\hline Sintomas ou Sinais & $89,9(8,7)$ & $88,6(14,9)$ & 0,591 & 0,78 & $<0,001$ \\
\hline
\end{tabular}


Análise da reprodutibilidade dos escores de qualidade de vida utilizando o gráfico de Bland Altman para a faixa etária de 6 meses a 4 anos.

Para a faixa etária de 6 meses a 4 anos, o gráfico de Bland-Altman mostrou boa concordância entre os escores de quase todos os domínios do questionário de qualidade de vida nos dois momentos estudados. Mesmo com amostra pequena, observa-se que os escores, com exceção do de Atividades Pessoais e Sociais, apresentaram boa distribuição aleatória ao redor do zero, com poucos pontos fora do limite (Figuras 3 a 8).

Figura 3. Avaliação Geral da Saúde - Bland Altman (6 meses a 4 anos)

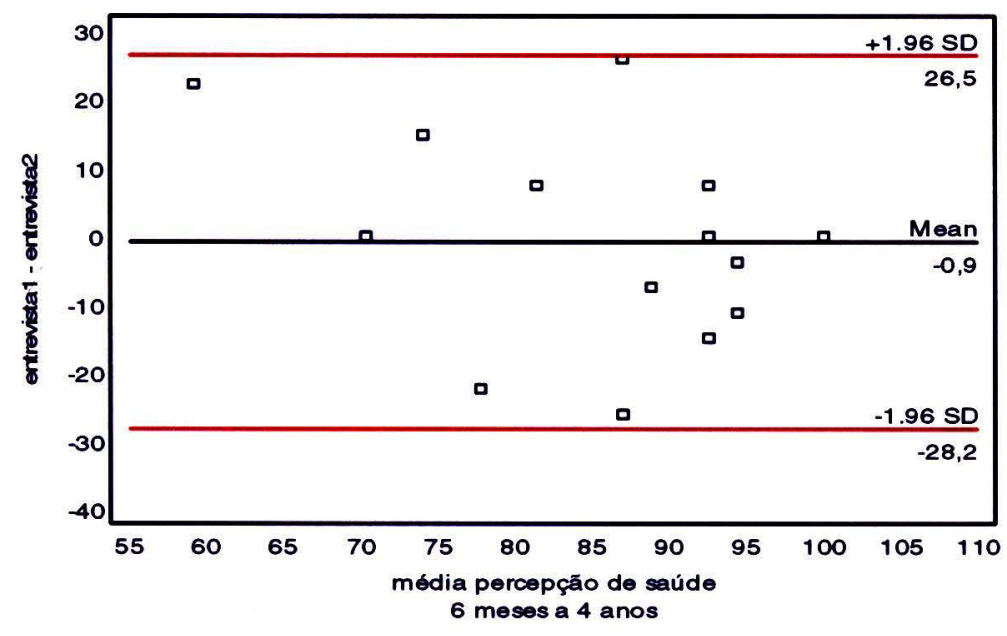

Figura 4. Resistência Física - Bland Altman (6 meses a 4 anos)

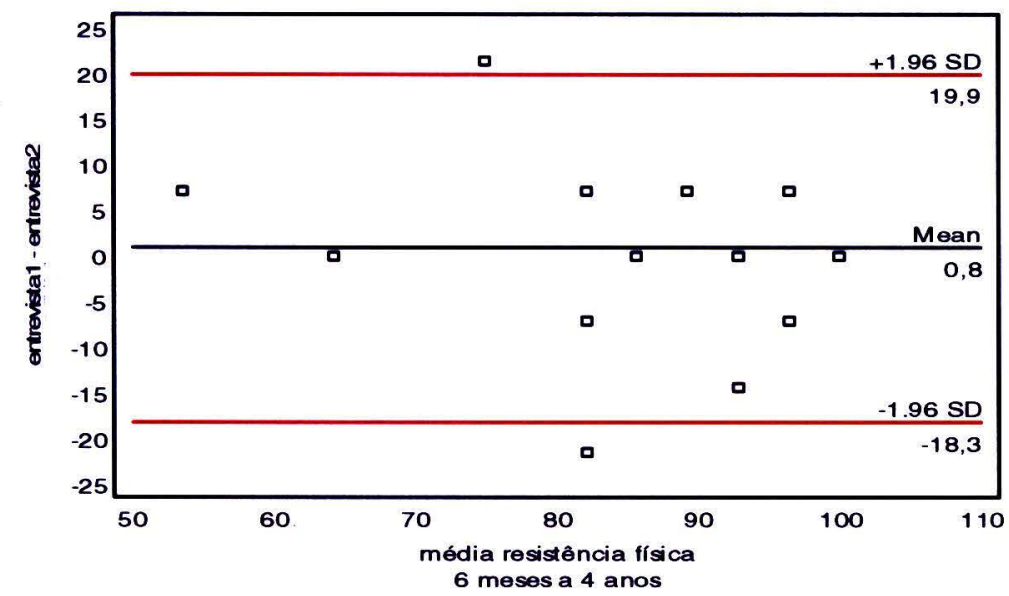


Figura 5. Estado Físico - Bland Altman (6 meses a 4 anos)

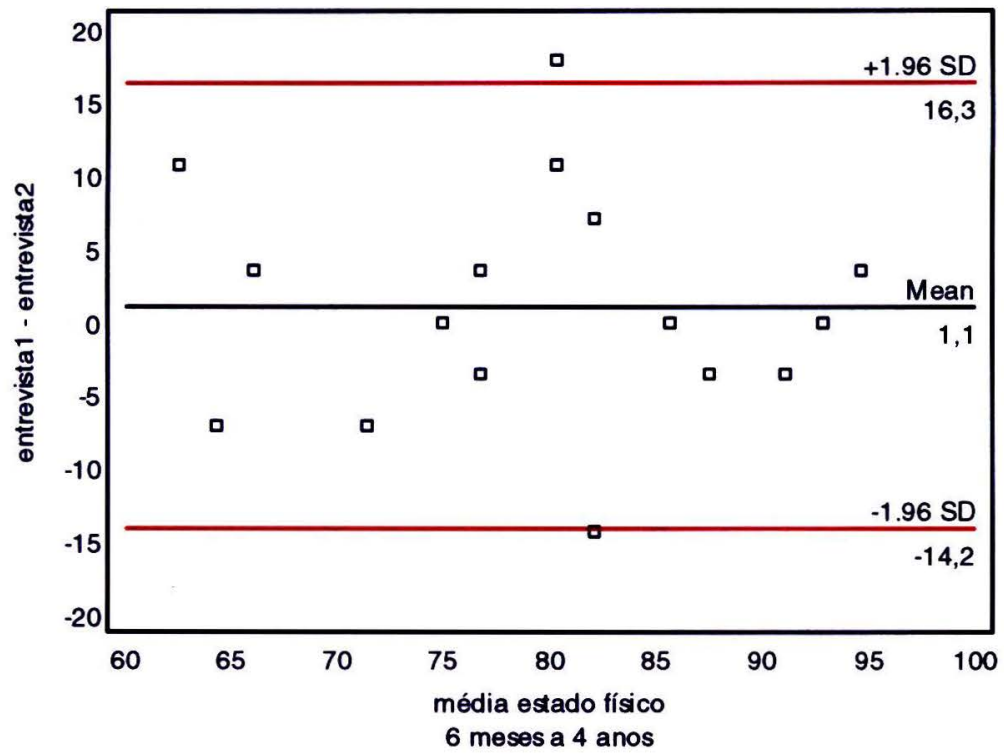

Figura 6. Atividades Pessoais e Sociais - Bland Altman (6 meses a 4 anos)

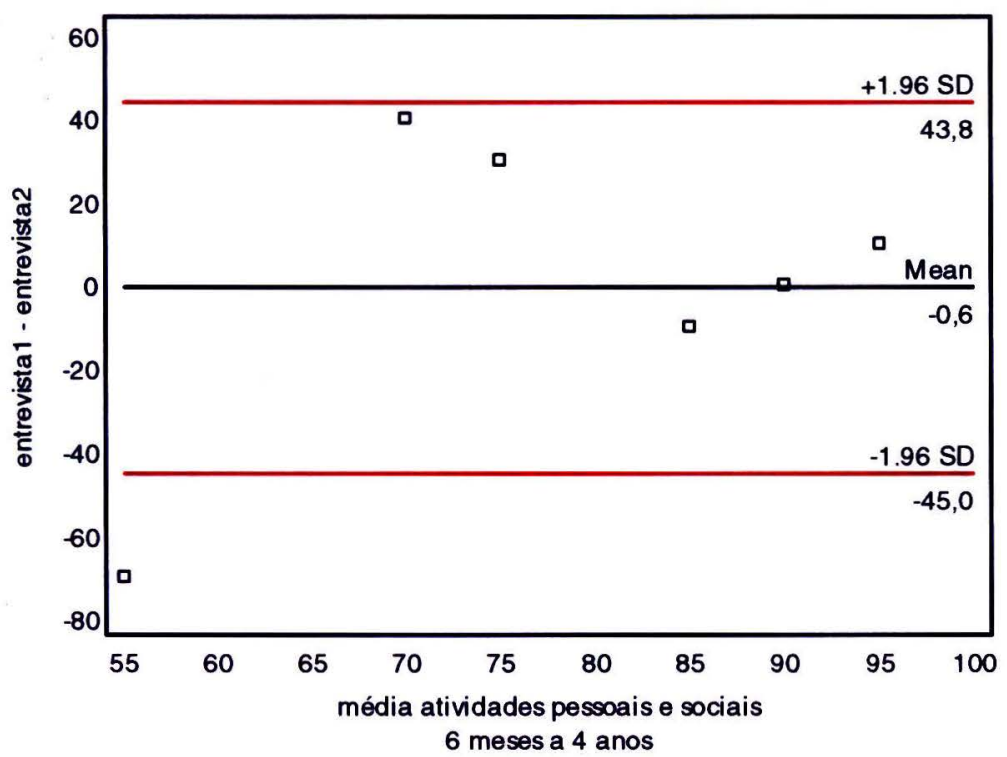


Figura 7. Utilização dos Serviços de Saúde - Bland Altman (6 meses a 4 anos)

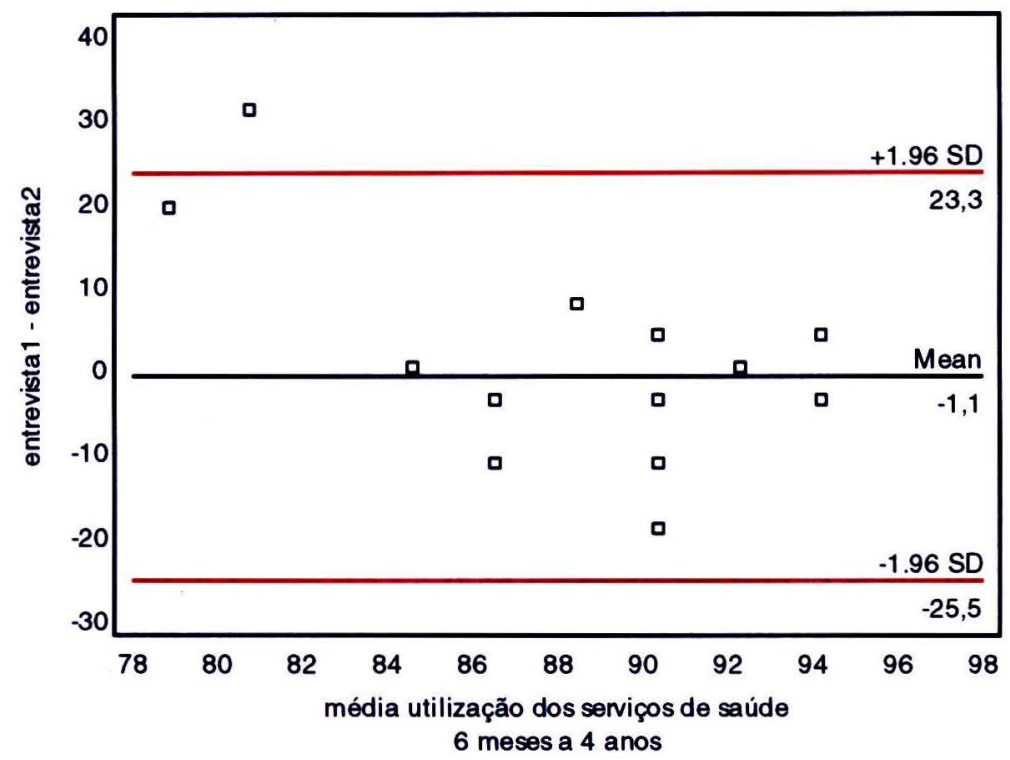

Figura 8. Sintomas ou Sinais - Bland Altman (6 meses a 4 anos)

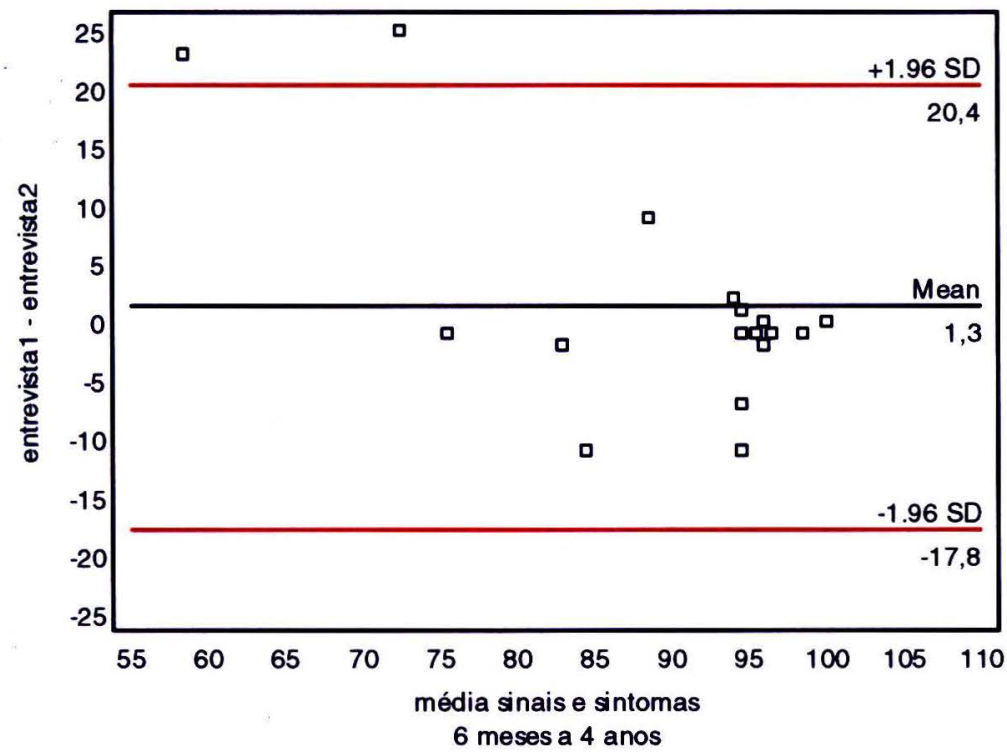


4.3.2 Faixa etária de 5 a 11 anos

\subsubsection{Avaliação da equivalência de mensuração}

\subsection{Consistência interna}

$\mathrm{Na}$ faixa etária de 5 a 11 anos houve consistência interna acima de 0,70 para os domínios de Avaliação Geral da Saúde, Saúde Psicológica, Estado Físico e Sintomas ou Sinais. Para os domínios de Resistência Física e Utilização dos Serviços de Saúde os $\alpha^{\prime} s$ de Cronbach foram 0,13 e 0,44 respectivamente (Tabela 10).

Na faixa de 5 a 11 anos, os domínios Estado Físico $(\mathrm{p}=0,023)$, Atividades Pessoais e Sociais $(p=0,002)$ e Utilização dos Serviços de Saúde $(p=0,013)$ não apresentaram aderência à curva Normal. 
Tabela 10: Análise descritiva e consistência interna do questionário de qualidade de vida para a faixa etária de 5 a 11 anos. CRT/SP, março 2005.

\begin{tabular}{|c|c|c|c|c|c|c|c|}
\hline \multirow[b]{2}{*}{ Parâmetro } & \multicolumn{7}{|c|}{ Domínio -5 a 11 anos $(n=35)$} \\
\hline & $\begin{array}{l}\text { Avaliação Geral } \\
\text { da Saúde }\end{array}$ & $\begin{array}{l}\text { Resistência } \\
\text { Física }\end{array}$ & $\begin{array}{l}\text { Saúde } \\
\text { Psicológica }\end{array}$ & Estado Físico & $\begin{array}{l}\text { Atividades } \\
\text { Pessoais e } \\
\text { Sociais }\end{array}$ & $\begin{array}{l}\text { Utilização dos } \\
\text { Serviços } \\
\text { de Saúde }\end{array}$ & $\begin{array}{l}\text { Sintomas ou } \\
\text { Sinais }\end{array}$ \\
\hline média (dp) & $77,50(17,11)$ & $81,02(17,83)$ & $66,58(11,49)$ & $86,55(20,24)$ & $86,48(8,32)$ & $93,19(5,83)$ & $87,09(11,44)$ \\
\hline mediana & 80,56 & 85,71 & 67,86 & 91,67 & 93,33 & 96,15 & 92,00 \\
\hline $\min -\max$ & $41,67-100,00$ & $28,57-100,00$ & $35,71-89,29$ & $0-100,00$ & $66,67-93,33$ & $76,92-100,00$ & $59,00-100,00$ \\
\hline$\alpha$ Cronbach & 0,76 & 0,13 & 0,78 & 0,90 & $\#$ & 0,44 & 0,85 \\
\hline
\end{tabular}

\#: O valor do $\alpha$ Cronbach foi negativo. 


\subsection{Análise Fatorial Confirmatória}

Os resultados da análise fatorial confirmatória para a faixa etária de 5 a 11 anos encontram-se na Tabela 11.

Para o domínio de Avaliação Geral da Saúde, originalmente composto por 4 questões, não foi possível obter uma solução fatorial, não havendo portanto uma confirmação deste escore.

Para o domínio de Resistência Física foi obtido um único fator que explicou mais de $67 \%$ da variância total. Das sete questões que compõem este domínio, seis foram confirmadas pelo fator, sendo que todas apresentaram cargas fatoriais altas.

No domínio de Avaliação do Estado Físico o único fator obtido explicou 91,51\% da variância total dos dados. Das seis questões deste domínio, cinco foram confirmadas neste fator e todas contribuíram fortemente para o mesmo, pois tiveram cargas fatoriais altas.

No domínio de Avaliação da Saúde Psicológica, um único fator explicou mais de 45\% da variância total. Das 28 questões que compõem este domínio, oito foram selecionadas para o fator, sendo que cinco delas apresentaram cargas fatoriais altas - " minha criança é muito tensa ou nervosa", minha criança argumenta demais", "minha criança é teimosa, emburrada, irritadiça", "minha criança tem o temperamento muito forte e perde a paciência facilmente" e "minha criança fica muito apegada aos adultos".

Para o compor o fator do domínio das Atividades Pessoais e Sociais foram confirmadas quatro questões da parte $B$ do domínio (respostas do tipo sim e não), relacionadas à escola. Todas as questões apresentaram cargas fatoriais altas e o fator explicou $86,43 \%$ da variância total.

No domínio de Utilização dos Serviços de Saúde, as questões que foram confirmadas neste fator foram aquelas referentes ao uso de medicação (Parte B). Foram confirmadas quatro questões e três delas foram as que mais contribuíram para o fator - “ 
medicamentos para a dor", ".medicamentos para chiado no peito", "cremes, pomadas para lesões, feridas" O fator explicou $47 \%$ da variância total.

Das vinte questões que originalmente faziam parte do domínio de Sintomas ou Sinais, sete foram confirmadas no único fator que explicou $87,95 \%$ da variância total dos dados. Observa-se também que todas questões no fator tiveram cargas fatoriais altas. 
Tabela 11: Resultados da análise fatorial confirmatória dos domínios do questionário de qualidade de vida para a faixa etária de 5 a 11 anos. CRT/SP, março 2005.

\begin{tabular}{|c|c|c|c|}
\hline Questões & Fator 1 & Variância & Uniqueness \\
\hline $\begin{array}{l}\text { Avaliação Geral da Saúde } \\
\text { 1. De maneira geral } \\
\text { 2. Fisicamente } \\
\text { 3. Emocionalmente } \\
\text { 4. Acerca de sua atividade em sala de aula }\end{array}$ & \multicolumn{3}{|c|}{ Não houve solução } \\
\hline $\begin{array}{l}\text { Variância total } \\
\text { \% variância explicada }\end{array}$ & & & \\
\hline $\begin{array}{l}\text { Resistência Física } \\
\text { 1. A saúde da minha criança é excelente } \\
\text { 2. Minha criança parece resistir a doença muito bem } \\
\text { 3. Minha criança parece menos sadia do que as outras crianças que eu conheço } \\
\text { 4. Minha criança é bastante suscetível a doenças que estão circulando } \\
\text { 5. Minha criança é pouco desajeitada } \\
\text { 6. Minha criança parece ter uma tendência a sofrer acidentes }\end{array}$ & $\begin{array}{l}-0,949 \\
-0,962 \\
0,758 \\
0,838 \\
0,573 \\
0,773\end{array}$ & $\begin{array}{l}0,900 \\
0,925 \\
0,574 \\
0,702 \\
0,328 \\
0,598 \\
4,027 \\
\end{array}$ & $\begin{array}{l}0,100 \\
0,075 \\
0,425 \\
0,297 \\
0,672 \\
0,403 \\
1,972 \\
\end{array}$ \\
\hline Variância total & & & 99 \\
\hline \% variância explicada & & $67,13 \%$ & \\
\hline $\begin{array}{l}\text { Avaliação do Estado Físico } \\
\text { 1. o tipo ou quantidade de atividades vigorosas como levantar objetos pesados, correr ou participar de esportes extenuantes } \\
\text { 2. o tipo ou quantidade de atividades moderadas, como arrastar uma mesa, carregar pacotes ou esportes como boliche } \\
\text { 3. caminhar, subir rampa ou subir alguns lances de escadas } \\
\text { 4. caminhar uma quadra } \\
\text { 5. agachar, curvar, levantar }\end{array}$ & $\begin{array}{l}-0,997 \\
0,997 \\
0,936 \\
0,997 \\
0,854\end{array}$ & $\begin{array}{l}0,994 \\
0,994 \\
0,786 \\
0,994 \\
0,729 \\
\end{array}$ & $\begin{array}{l}0,007 \\
0,007 \\
0,125 \\
0,007 \\
0,271 \\
\end{array}$ \\
\hline & & 4,497 & 0,417 \\
\hline $\begin{array}{l}\text { Variância total } \\
\text { \% variância explicada }\end{array}$ & & 91,51 & 14 \\
\hline
\end{tabular}


Avaliação da Saúde Psicológica

3. Minha criança é muito tensa ou nervosa

5. Minha criança é medrosa ou ansiosa

6. Minha criança argumenta demais

20. Minha criança é teimosa, emburrada, irritadiça

21. Minha criança tem o temperamento muito forte e perde a paciência facilmente

25. Minha criança fica muito apegada aos adultos

27. Minha criança solicita muita atenção

\section{Variância total}

\% variância explicada

\section{Avaliação das Atividades Pessoais e Sociais}

3. Sua criança repetiu alguma série

4. No geral, sua criança teve a freqüência na escola comprometida devido à sua condição de saúde

6. No geral, sua criança participa das atividades esportivas na escola

7. Sua criança freqüenta classe especial ou necessita de ajuda especial na escola devido a incapacidade ou problema de saúde

(20)

\section{Variância total}

\% variância explicada

Utilização dos Serviços de Saúde

6. medicamento para a dor

8. medicamentos para resfriado

9. medicamentos para chiado no peito

10. cremes, pomadas para lesões, feridas

\begin{tabular}{|c|c|c|}
\hline Fator 1 & Variância & Uniqueness \\
\hline 0,819 & 0,670 & 0,329 \\
\hline$-0,316$ & 0,099 & 0,900 \\
\hline$-0,300$ & 0,090 & 0,910 \\
\hline 0,676 & 0,457 & 0,542 \\
\hline 0,826 & 0,682 & 0,319 \\
\hline 0,970 & 0,941 & 0,059 \\
\hline$-0,840$ & 0,706 & 0,294 \\
\hline \multirow[t]{4}{*}{$-0,249$} & 0,062 & 0,938 \\
\hline & 3,707 & 4,291 \\
\hline & \multicolumn{2}{|c|}{7,998} \\
\hline & $46,35 \%$ & \\
\hline 0,842 & 0,709 & 0,292 \\
\hline 0,944 & 0,891 & 0,108 \\
\hline$-0,997$ & 0,994 & 0,007 \\
\hline \multirow[t]{4}{*}{0,929} & 0,863 & 0,136 \\
\hline & 3,457 & 0,543 \\
\hline & \multicolumn{2}{|c|}{4,000} \\
\hline & $86,43 \%$ & \\
\hline 0,222 & 0,049 & 0,951 \\
\hline 0,894 & 0,799 & 0,200 \\
\hline 0,835 & 0,697 & 0,303 \\
\hline \multirow[t]{4}{*}{0,580} & 0,336 & 0,663 \\
\hline & 1,881 & 2,117 \\
\hline & \multicolumn{2}{|c|}{3,998} \\
\hline & $47,05 \%$ & \\
\hline 0,997 & 0,994 & 0,007 \\
\hline 0,997 & 0,994 & 0,007 \\
\hline 0,997 & 0,994 & 0,007 \\
\hline 0,686 & 0,470 & 0,530 \\
\hline 0,849 & 0,721 & 0,279 \\
\hline$-0,997$ & 0,994 & 0,007 \\
\hline \multirow[t]{4}{*}{0,997} & 0,994 & 0,007 \\
\hline & 6,161 & 0,844 \\
\hline & \multicolumn{2}{|c|}{7,005} \\
\hline & 87,95 & \\
\hline
\end{tabular}

\begin{tabular}{|c|c|c|c|}
\hline Variância total & & \multicolumn{2}{|c|}{3,998} \\
\hline \% variância explicada & & $47,05 \%$ & \\
\hline Sintomas ou Sinais & & & \\
\hline 2. chiado, tosse & 0,997 & 0,994 & 0,007 \\
\hline 8. febre, suores noturnos, tremores e calafrios & 0,997 & 0,994 & 0,007 \\
\hline 11. problemas nos olhos ou para enxergar & 0,997 & 0,994 & 0,007 \\
\hline 12. dor de cabeça & 0,686 & 0,470 & 0,530 \\
\hline 16. nariz escorrendo ou problemas de sinusite & 0,849 & 0,721 & 0,279 \\
\hline 19. dor de ouvido & $-0,997$ & 0,994 & 0,007 \\
\hline \multirow[t]{2}{*}{ 20. desconforto ou mal estar geral } & 0,997 & 0,994 & 0,007 \\
\hline & & 6,161 & 0,844 \\
\hline Variância total & & \multicolumn{2}{|c|}{7,005} \\
\hline \% variância explicada & & 87,95 & \\
\hline
\end{tabular}




\subsection{Validação}

\section{Validade de Constructo}

\section{Comparação de médias}

$\mathrm{Na}$ faixa etária de 5 a 11 anos, observa-se que houve diferença estatisticamente significativa nas médias dos escores dos seguintes domínios de qualidade de vida quando se faz a comparação entre crianças não doentes e doentes: Avaliação Geral da Saúde $(90,74$ x 74,71; 0,033), Estado Físico $(100,00$ x 83,76; p=0,004) e Sintomas ou Sinais $(97,33 \times 84,97 ; \mathrm{p}=0,006)$ (Tabela 12$)$. Nos demais domínios não foi feito o teste estatístico por falta de poder.

Tabela 12: Comparação de médias dos domínios da faixa etária de 5 a 11 anos em relação às categorias do CDC. CRT/SP, março 2005.

\begin{tabular}{|c|c|c|c|c|}
\hline Domínio & $\begin{array}{l}\text { Não doente } \\
n=6\end{array}$ & $\begin{array}{l}5 \text { a } 11 \text { anos } \\
\text { Doente } \\
\text { n=29 } \\
\text { lp) }\end{array}$ & $\mathbf{p}^{*}$ & $\begin{array}{l}\text { Poder } \\
\text { do } \\
\text { teste }\end{array}$ \\
\hline Avaliação Geral da Saúde & $90,74(8,55)$ & $74,71(17,22)$ & 0,033 & - \\
\hline Resistência Física & $89,29(10,83)$ & $79,31(18,64)$ & $\mathrm{nr}$ & 0,30 \\
\hline Estado Físico & $100,00(0)$ & $83,76(21,23)$ & 0,004 & - \\
\hline Saúde Psicológica & $74,40(9,82)$ & $64,96(11,28)$ & 0,059 & 0,50 \\
\hline Atividades Pessoais e Sociais & $87,78(8,86)$ & $86,20(8,34)$ & $\mathrm{nr}$ & 0,10 \\
\hline Utilização Serviços de Saúde & $95,51(2,89)$ & $92,70(6,20)$ & $\mathrm{nr}$ & 0,38 \\
\hline Sintomas ou Sinais & $97,33(2,73)$ & $84,97(11,42)$ & 0,006 & 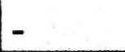 \\
\hline
\end{tabular}

p*: Teste de Mann-Whitney

${ }^{1}$ Não-doente: categorias N+A; Doente: categorias B+C;

nr: não realizado. 


\section{Correlação com contagem de células de defesa CD4 e carga viral}

Os escores dos domínios foram correlacionados com a contagem de células de defesa CD4 e carga viral, analisadas com a transformação logarítmica. No grupo de 5 a 11 anos $(n=35)$, a análise de correlação com a carga viral foi válida para 23 crianças, pois 12 delas apresentaram carga viral indetectável ( $<400$ cópias). Espera-se, nessa análise que quanto maior o CD4, melhores sejam os escores de qualidade de vida (correlação positiva) e quanto maior a carga viral, menores os escores de qualidade de vida (correlação negativa).

Para a faixa etária de 5 a 11 anos obteve-se coeficiente de correlação negativo e superior a 0,30 entre o escore de Atividades Pessoais e Sociais e a carga viral e entre o escore de Utilização dos Serviços de Saúde e carga viral (Tabela 13). As correlações com o CD4 nessa faixa foram abaixo de 0,25 e algumas delas negativas - CD4 e Saúde Psicológica, CD4 e Atividades Pessoais e Sociais e CD4 e sintomas -o que não era esperado (Tabela 13). 
Tabela 13: Coeficiente de correlação de Spearman (r) entre os escores dos diferentes domínios e a contagem de célula de defesa CD4 e Carga Viral para a faixa etária de 5 a 11 anos. CRT/SP, março 2005.

\begin{tabular}{l|lc}
\hline Domínio & \multicolumn{1}{|c}{ 5 a 11 anos (n=23) } \\
& $\frac{\text { CD4 }}{\mathbf{r}(\mathbf{p})}$ & $\mathbf{r}(\mathbf{p})$ \\
\hline Avaliação Geral da Saúde & $0,00(0,987)$ & $0,01(0,947)$ \\
Resistência Física & $0,25(0,149)$ & $0,03(0,876)$ \\
Estado Físico & $0,00(0,987)$ & $-0,13(0,548)$ \\
Saúde Psicológica & $-0,04(0,816)$ & $-0,01(0,944)$ \\
Atividades Pessoais e Sociais & $-0,12(0,500)$ & $-0,33(0,123)$ \\
Utilização Serviços de Saúde & $0,20(0,261)$ & $-0,30(0,179)$ \\
Sintomas ou Sinais & $-0,04(0,840)$ & $-0,03(0,884)$ \\
\hline
\end{tabular}




\section{Correlação com a Utilização dos Serviços de Saúde}

$\mathrm{Na}$ faixa etária de 5 a 11 anos todas as correlações com as noites passadas no hospital foram negativas, obtendo-se coeficientes de correlação sempre inferiores a 0,30. Houve correlação estatisticamente significativa entre o número de visitas ao médico e a Utilização dos Serviços de Saúde $(r=-0,39 ; \mathrm{p}=0,022)$ sendo que se há um aumento do número de visitas, espera-se uma piora (freqüentar mais o serviço) no escore de utilização do serviço (Tabela 14).

Tabela 14: Coeficientes de correlação de Spearman (r) entre os escores dos diferentes domínios e marcadores de Utilização dos Serviços de Saúde - noites no hospital e visitas ao médico no último mês para a faixa etária de 5 a 11 anos. CRT/SP, março 2005.

\begin{tabular}{l|lc}
\hline Domínio & \multicolumn{2}{|c}{5 a 11 anos $(\mathbf{n = 3 5})$} \\
\hline Avoites & $\frac{\text { Visitas }}{\mathbf{r}(\mathbf{p})}$ \\
\hline Resistência Física & $-0,14(0,435)$ & $-0,23(0,191)$ \\
Estado Físico & $-0,16(0,375)$ & $0,10(0,540)$ \\
Saúde Psicológica & $-0,26(0,139)$ & $-0,09(0,600)$ \\
Atividades Pessoais e Sociais & $-0,04(0,808)$ & $0,04(0,819)$ \\
Utilização Serviços de Saúde & $-0,06(0,753)$ & $0,07(0,685)$ \\
Sintomas ou Sinais & $-0,29(0,088)$ & $-0,39(0,022)$ \\
\hline
\end{tabular}




\subsection{Reprodutibilidade}

A Tabela 15 mostra a comparação dos escores de qualidade de vida entre o teste e o reteste para a faixa etária de 5 a 11 anos. No teste de comparação de médias observase, que com exceção dos domínios de Estado Físico e Sintomas ou Sinais, todos os demais domínios não apresentaram diferenças estatisticamente significativas nas médias dos escores nos dois momentos estudados.

Em relação ao coeficiente de correlação intraclasse, as correlações estatisticamente significativas estiveram entre 0,40 e 0,70 . Para os domínios das Atividade Pessoais e Sociais e Utilização dos Serviços de Saúde, as correlações não foram significativas e estiveram abaixo de 0,30 (Tabela 15).

Tabela 15: Comparação teste-reteste entre os escores nos domínios e faixa etária de 5 a 11 anos e coeficientes de correlação intraclasse $\left(r_{\text {icc }}\right)$. CRT/SP, março 2005.

\begin{tabular}{|c|c|c|c|c|c|}
\hline \multirow[b]{2}{*}{ Domínio } & \multicolumn{5}{|c|}{5 a 11 anos $(n=28)$} \\
\hline & Teste $\mathbf{M}$ & $\frac{\text { Reteste }}{\text { (dp) }}$ & $\mathbf{p}$ & $\mathbf{r}_{\text {ice }}$ & $\mathbf{p}$ \\
\hline Avaliação Geral da Saúde & $77,8(16,1)$ & $80,8(14,7)$ & 0,299 & 0,54 & 0,023 \\
\hline Resistência Física & $83,7(15,2)$ & $83,2(12,8)$ & 0,853 & 0,48 & 0,010 \\
\hline Estado Físico & $88,9(14,3)$ & $96,1(8,4)$ & 0,008 & 0,41 & 0,029 \\
\hline Saúde Psicológica & $67,3(10,6)$ & $70,3(12,4)$ & 0,093 & 0,70 & $<0,001$ \\
\hline Atividades Pessoais e Sociais & $86,4(8,0)$ & $88,3(6,9)$ & 0,245 & 0,36 & 0,058 \\
\hline Utilização Serviços de Saúde & $93,0(6,5)$ & $91,8(6,0)$ & 0,427 & 0,15 & 0,441 \\
\hline Sintomas ou Sinais & $86,4(11,9)$ & $90,8(8,0)$ & 0,032 & 0,53 & 0,004 \\
\hline
\end{tabular}


Análise da reprodutibilidade dos escores de qualidade de vida utilizando o gráfico de Bland Altman para a faixa etária de 5 a 11 anos.

Para a faixa etária de 5 a 11 anos, observou-se que houve uma boa concordância entre os escores de todos os domínios do questionário de qualidade de vida nos dois momentos. Houve boa distribuição aleatória dos escores ao redor do zero, com exceção do de Estado Físico, com poucos pontos fora do limite (Figuras 9 a 15).

Figura 9: Avaliação Geral da Saúde - Bland Altman (5-11 anos).

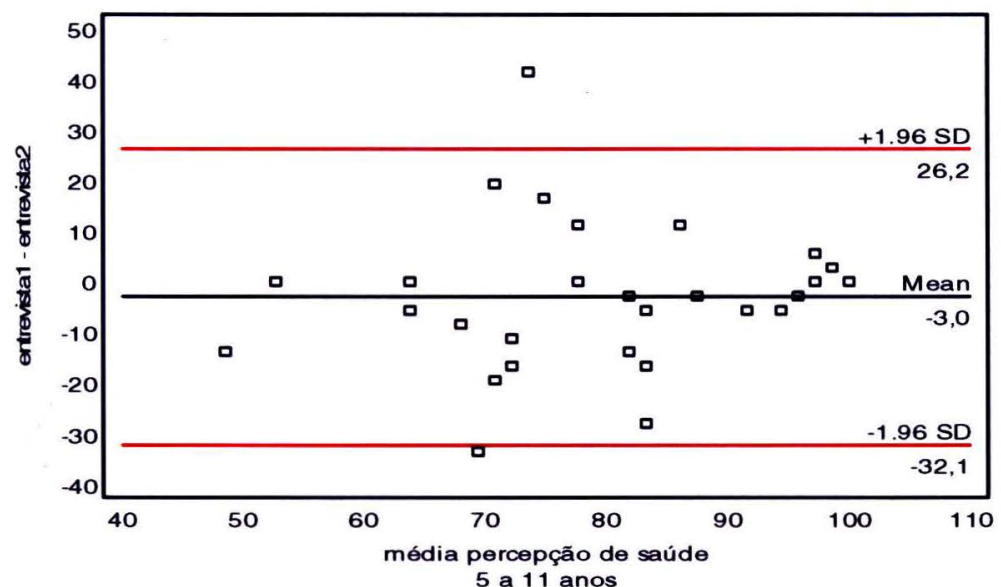

Figura 10: Resistência Física - Bland Altman (5-11 anos).

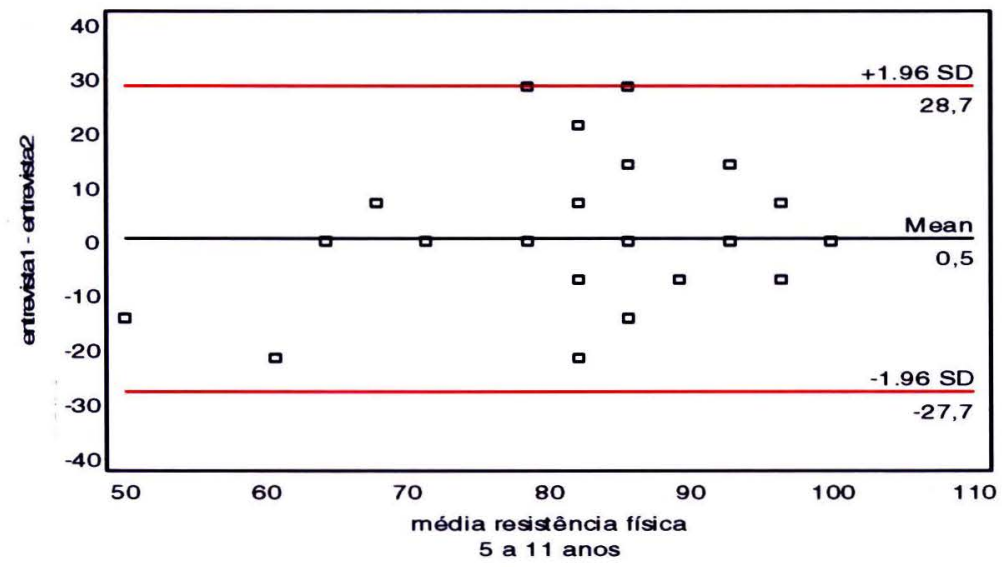


Figura 11: Estado Físico- Bland Altman (5-11 anos).

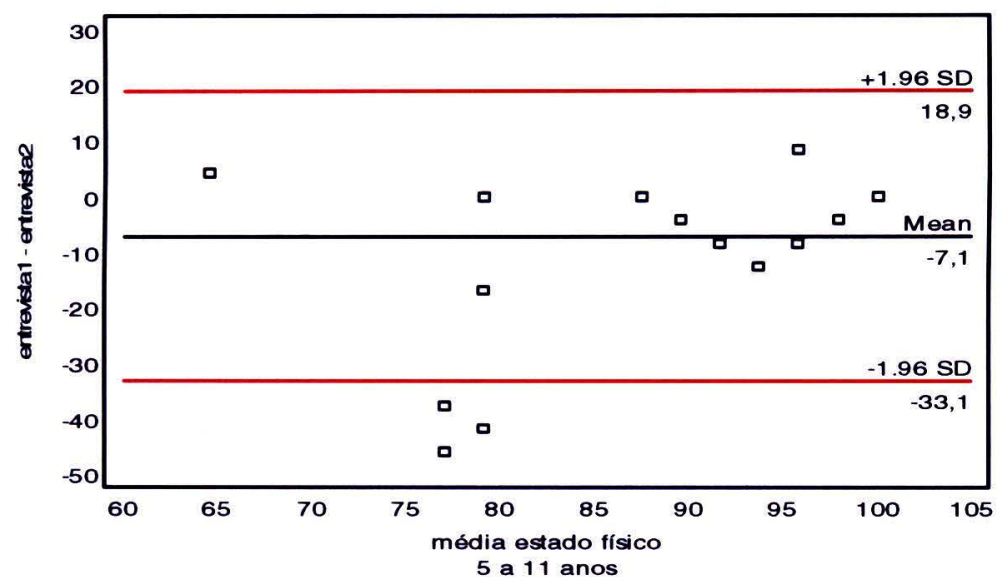

Figura 12: Avaliação Psicológica- Bland Altman (5-11 anos).

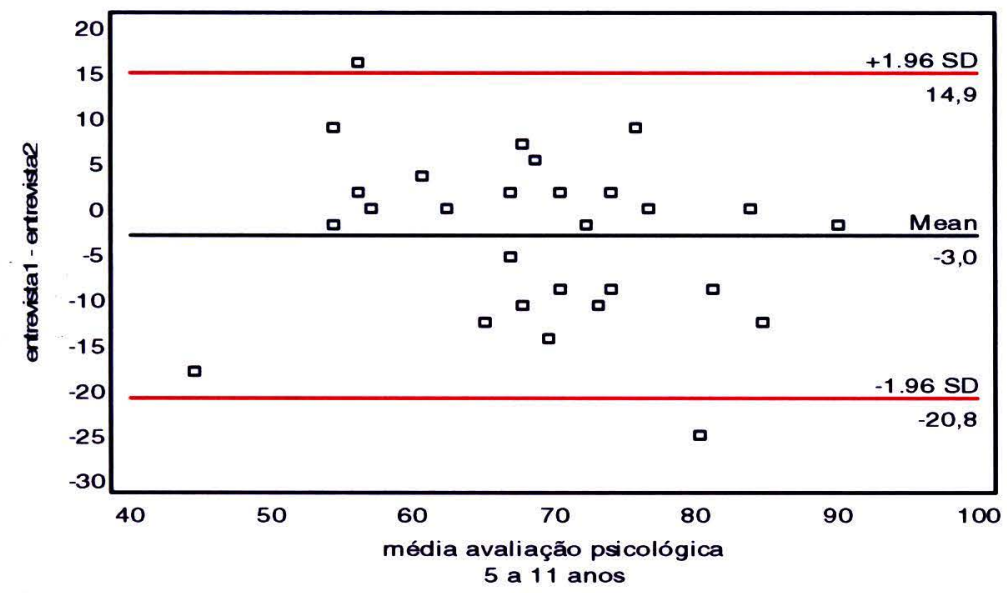

Figura 13: Atividades Pessoais e Sociais- Bland Altman (5-11 anos).

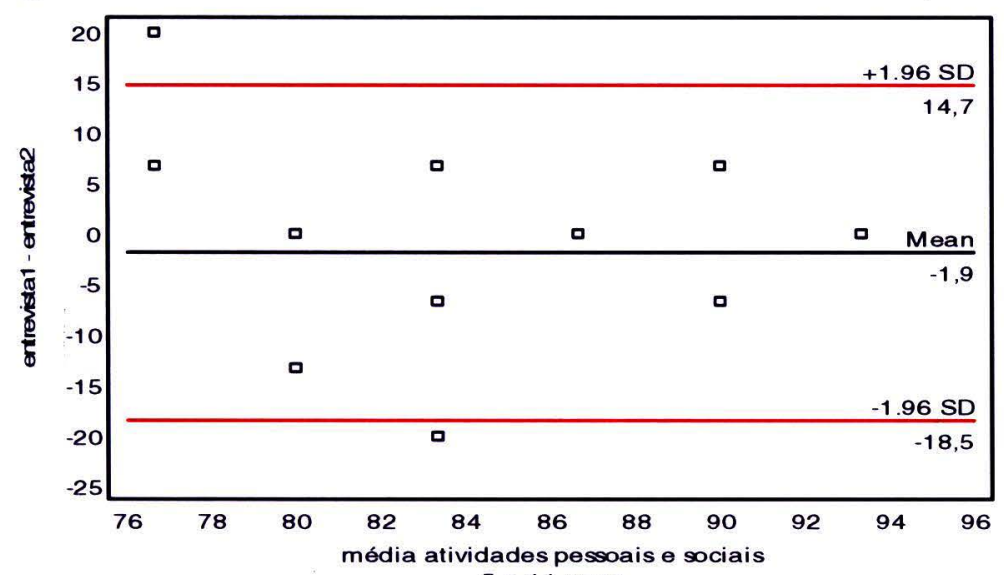

5 a 11 anos 
Figura 14: Utilização dos Serviços de Saúde- Bland Altman (5-11 anos).

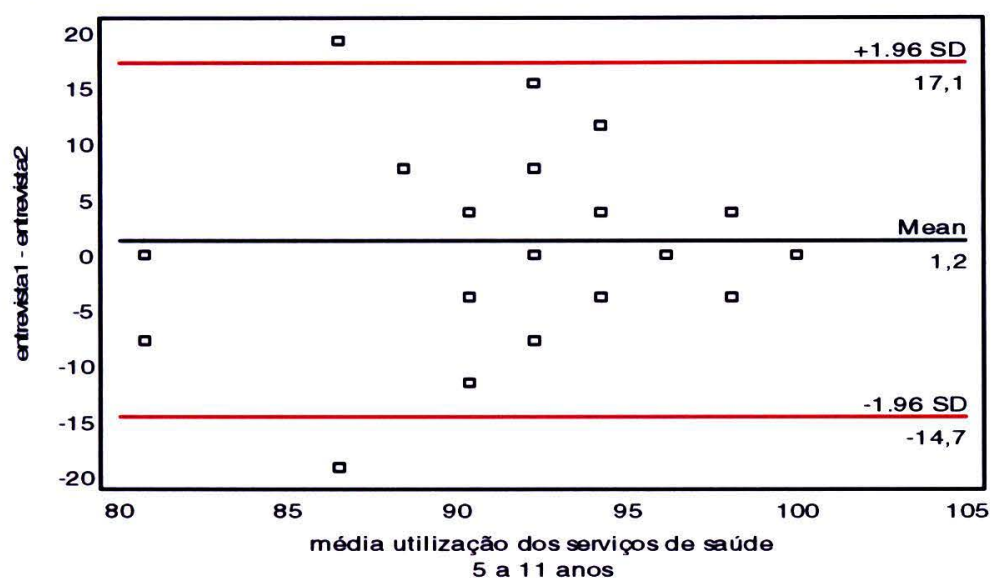

Figura 15: Sintomas ou Sinais - Bland Altman (5-11 anos).

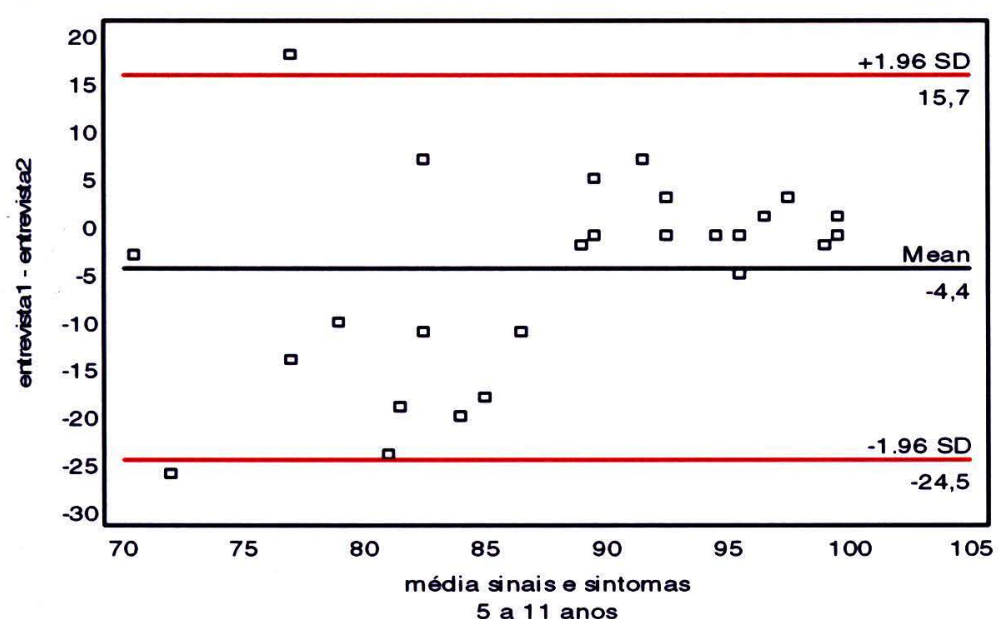

5 a 11 anos 


\subsubsection{Faixa etária de 12 a 20 anos}

\subsubsection{Avaliação da equivalência de mensuração}

\subsection{Consistência interna}

$\mathrm{Na}$ faixa etária de 12 a 20 anos a consistência interna foi boa e esteve entre 0,82 e 0,93 para os domínios de Avaliação Geral da Saúde, Estado Físico, Saúde Psicológica e Sintomas ou Sinais, enquanto que para o domínio de Utilização dos Serviços de Saúde ela foi de 0,47 (Tabela 16).

Em relação ao teste de aderência à curva Normal, na faixa etária estudada somente o domínio Estado Físico $(\mathrm{p}=0,014)$ não apresentou aderência à curva Normal . 
Tabela 16: Análise descritiva e consistência interna do questionário de qualidade de vida para a faixa etária de 12 a 20 anos. CRT/SP, março 2005.

\begin{tabular}{l|llllll}
\hline Parâmetro & Avaliação Geral & Estado Físico & $\begin{array}{l}\text { Domínio 12 a 20 anos (n=20) } \\
\text { Saúde } \\
\text { Psicológica }\end{array}$ & $\begin{array}{l}\text { Atividades } \\
\text { Pessoais e } \\
\text { Sociais }\end{array}$ & $\begin{array}{l}\text { Utilização dos } \\
\text { Serviços } \\
\text { de Saúde }\end{array}$ & $\begin{array}{l}\text { Sintomas ou } \\
\text { Sinais }\end{array}$ \\
\hline média (dp) & $80,83(19,29)$ & $85,00(27,52)$ & $68,40(13,81)$ & $79,33(20,62)$ & $91,15(9,00)$ & $88,25(9,86)$ \\
mediana & 83,33 & 100,00 & 73,21 & 83,33 & 92,31 & 90,50 \\
min-max & $22,00-100,00$ & $0-100,00$ & $26,79-83,93$ & $6,67-100,00$ & $61,54-100,00$ & $60,00-99,00$ \\
a Cronbach & $\mathbf{0 , 8 5}$ & $\mathbf{0 , 9 3}$ & $\mathbf{0 , 8 3}$ & $\mathbf{0 , 8 3}$ & $\mathbf{0 , 4 7}$ & $\mathbf{0 , 8 2}$ \\
\hline
\end{tabular}

\#: O valor do $\alpha$ Cronbach foi negativo. 


\subsection{Análise Fatorial Confirmatória}

A Tabela 17 mostra a análise fatorial confirmatória para o questionário de qualidade de vida, para a faixa etária de 12 a 20 anos.

Para o domínio de Avaliação Geral da Saúde foram confirmadas três questões para compor um único fator que explicou mais de $76 \%$ da variância total. As cargas fatoriais para as três questões foram altas, mostrando o quanto elas são importantes para a composição do fator. Ainda neste domínio, verifica-se que a questão sobre como a criança/adolescente tem se sentido "com relação às atividades diárias como a atividade em sala de aula, emprego ou trabalho doméstico" não foi selecionada para compor o fator.

No domínio de Avaliação do Estado Físico, três das seis questões que originalmente compunham este domínio foram confrimadas neste único fator que explicou mais de $80 \%$ da variância total. As questões " o quanto a saúde interferiu com o tipo ou quantidade de atividades vigorosas"..., "caminhar, subir rampa"...e "agachar, curvar, levantar" apresentaram cargas fatoriais altas, mostrando, assim, as suas contribuições para o fator.

O domínio de Avaliação da Saúde Psicológica também apresentou solução de um único fator, sendo que das 28 questões deste domínio, apenas seis foram confirmadas pelo fator. $O$ fator explicou $54 \%$ da variância total dos dados e as questões que mais contribuíram para o fator foram "minha criança é irrequieta ou superativa, não consegue ficar sentada", "minha criança é teimosa, emburrada, irritadiça", minha criança tem o temperamento muito forte e perde a paciência facilmente".

No domínio de Avaliação das Atividades Pessoais e Sociais, três questões foram selecionadas para compor o único fator que explicou $63,88 \%$ da variância total. As questões confirmadas contribuíram substancialmente para a formação do fator e são aquelas referentes à parte $\mathrm{B}$ do domínio (respostas sim e não), mais relacionadas à escola - "sua criança repetiu alguma série", "no geral, sua criança teve a freqüência na 
escola comprometida devido à sua condição de saúde", "no geral, sua criança participa das atividades esportivas na escola".

Com relação ao domínio de Utilização dos Serviços de Saúde, somente duas questões foram selecionadas para compor um único fator que explicou $63,40 \%$ da variância total. Estas questões referem-se ao uso de medicação - "medicamento para dor" e "antibióticos".

No domínio de Sintomas ou Sinais, das vinte questões, sete foram selecionadas para o único fator. As questões confirmadas tiveram cargas fatoriais altas e contribuíram para explicar $82,40 \%$ da variância total. 
Tabela 17: Análise fatorial confirmatória dos domínios do questionário de qualidade de vida para a faixa etária de 12 a 20 anos. CRT/SP, março 2005.

\begin{tabular}{|c|c|c|c|}
\hline 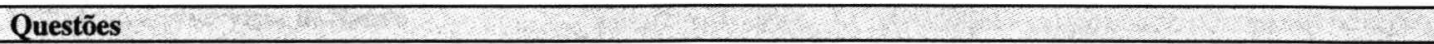 & Fator 1 & Variância & Uniqueness \\
\hline $\begin{array}{l}\text { Avaliação Geral da Saúde } \\
\text { 1. De maneira geral } \\
\text { 2. Fisicamente } \\
\text { 3. Emocionalmente }\end{array}$ & $\begin{array}{l}0,997 \\
0,997 \\
0,554\end{array}$ & $\begin{array}{l}0,994 \\
0,994 \\
0,307 \\
2,295\end{array}$ & $\begin{array}{l}0,007 \\
0,007 \\
0,693 \\
0,707\end{array}$ \\
\hline Variância total & & \multicolumn{2}{|c|}{3,002} \\
\hline \% variância explicada & & \multicolumn{2}{|l|}{$76,45 \%$} \\
\hline $\begin{array}{l}\text { Avaliação do Estado Físico } \\
\text { 1. o tipo ou quantidade de atividades vigorosas como levantar objetos pesados, correr ou participar de esportes extenuantes } \\
\text { 3. caminhar, subir rampa ou subir alguns lances de escadas } \\
\text { 5. agachar, curvar, levantar }\end{array}$ & $\begin{array}{l}0,657 \\
0,997 \\
0,997\end{array}$ & $\begin{array}{l}0,432 \\
0,994 \\
0,994\end{array}$ & $\begin{array}{l}0,568 \\
0,007 \\
0,007\end{array}$ \\
\hline & & 2,420 & 0,582 \\
\hline Variância total & & \multicolumn{2}{|c|}{3,002} \\
\hline \% variância explicada & & \multicolumn{2}{|l|}{$80,61 \%$} \\
\hline $\begin{array}{l}\text { Avaliação da Saúde Psicológica } \\
\text { 18. Minha criança tem muita dificuldade em tirar certas idéias da cabeça (tem obsessões) } \\
\text { 19. Minha criança é irrequieta ou superativa, não consegue ficar sentada } \\
\text { 20. Minha criança é teimosa, emburrada, irritadiça } \\
\text { 21. Minha criança tem o temperamento muito forte e perde a paciência facilmente } \\
\text { 26. Minha criança mantém suas coisas para si mesma } \\
\text { 28. Minha criança é muito dependente dos outros }\end{array}$ & $\begin{array}{l}0,329 \\
0,577 \\
0,996 \\
0,918 \\
0,784 \\
0,592\end{array}$ & $\begin{array}{l}0,108 \\
0,333 \\
0,992 \\
0,843 \\
0,615 \\
0,350\end{array}$ & $\begin{array}{l}0,892 \\
0,668 \\
0,007 \\
0,157 \\
0,385 \\
0,649\end{array}$ \\
\hline & & 3,241 & 2,758 \\
\hline Variância total & & \multicolumn{2}{|c|}{5,999} \\
\hline \% variância explicada & & \multicolumn{2}{|c|}{$54,03 \%$} \\
\hline $\begin{array}{l}\text { Avaliação das Atividades Pessoais e Sociais } \\
\text { 3. Sua criança repetiu alguma série } \\
\text { 4. No geral, sua criança teve a frequêencia na escola comprometida devido à sua condição de saúde } \\
\text { 6. No geral, sua criança participa das atividades esportivas na escola }\end{array}$ & $\begin{array}{l}-0,673 \\
-0,686 \\
0,996\end{array}$ & $\begin{array}{l}0,453 \\
0,470 \\
0,992\end{array}$ & $\begin{array}{l}0,546 \\
0,530 \\
0,007\end{array}$ \\
\hline & & 1,915 & 1,083 \\
\hline Variância total & & \multicolumn{2}{|c|}{$\begin{array}{l}1,003 \\
2,998\end{array}$} \\
\hline \% variância explicada & & \multicolumn{2}{|l|}{$63,88 \%$} \\
\hline
\end{tabular}


Continuação

Questões

Utilização dos Serviços de Saúde

6. medicamento para a dor

7. antibióticos

Variância total

\% variância explicada

\% variância explicad

1. dor física ou no corpo todo

3. náuseas, vômitos, dor abdominal, dor de estômago

10. problemas de sono

11. problemas nos olhos ou para enxergar

12. dor de cabeça

17. dor no músculo, nas articulações (juntas) ou nos ossos

20. desconforto ou mal estar geral

Variância total

\% variância explicada

\begin{tabular}{|l|l|l}
\hline Fator 1 & Variância & Uniqueness \\
\hline
\end{tabular}

\begin{tabular}{l|l}
0,828 & 0,686
\end{tabular}

\begin{tabular}{l|l}
0,828 & 0,686 \\
0.763 & 0.582 \\
\hline
\end{tabular}

0,315
0,417

\begin{tabular}{l|l|l}
0,997 & 0,994 & 0,007
\end{tabular}

\begin{tabular}{l|l|l}
$-0,997$ & 0,994 & 0,007
\end{tabular}

\begin{tabular}{l|ll}
0,997 & 0,994 & 0,007
\end{tabular} 


\subsection{Validação}

\section{Validade de Constructo}

\section{Comparação de médias}

A Tabela 18 mostra a comparação das médias dos escores de qualidade de vida entre as categorias clínicas do CDC, para a faixa etária de 12 a 20 anos.

Observa-se que houve diferença estatisticamente significativa nas médias dos escores do domínio de Sintomas ou Sinais, quando se faz a comparação entre os grupos de adolescentes doentes e não doentes $(86,38 \times 95,75 ; \mathrm{p}=0,007)$. Nos demais domínios não foi feito o teste estatístico por falta de poder (Tabela 18).

Tabela 18: Comparação de médias dos domínios da faixa etária de 12 a 20 anos em relação às categorias do CDC. CRT/SP, março 2005.

\begin{tabular}{|c|c|c|c|c|}
\hline Domínio & $\begin{array}{l}\text { Nâo doente } \\
n=4\end{array}$ & $\begin{array}{l}2 \text { a } 20 \text { anos } \\
\text { Doente } \\
n=16\end{array}$ & p* & $\begin{array}{l}\text { Poder } \\
\text { do teste }\end{array}$ \\
\hline Avaliação Geral da Saúde & $85,50(8,33)$ & $79,17(21,03)$ & $\mathrm{nr}$ & 0,12 \\
\hline Estado Físico & $100,00(0,00)$ & $81,25(29,74)$ & $\mathrm{nr}$ & - \\
\hline Saúde Psicológica & $66,07(13,76)$ & $68,97(14,20)$ & $\mathrm{nr}$ & 0,08 \\
\hline Atividades Pessoais e Sociais & $90,00(8,61)$ & $76,67(22,05)$ & $\mathrm{nr}$ & 0,33 \\
\hline Utilização Serviços de Saúde & $95,19(1,92)$ & $90,14(9,83)$ & $\mathrm{nr}$ & 0,40 \\
\hline Sintomas ou Sinais & $95,75(2,87)$ & $86,38(10,13)$ & 0,007 & - \\
\hline
\end{tabular}

p*: Teste de Mann-Whitney

${ }^{1}$ Não-doente: categorias N+A; Doente: categorias B+C; nr: não realizado. 


\section{Correlação com contagem de células de defesa CD4 e carga viral}

Os escores dos domínios foram correlacionados com a contagem de células de defesa CD4 e carga viral, analisadas com a transformação logarítmica. No grupo de 12 a 20 anos a análise foi realizada com 13 adolescentes uma vez que 7 deles tinham carga viral indetectável. Espera-se, nessa análise que quanto maior o $\mathrm{CD} 4$, melhores sejam os escores de qualidade de vida (correlação positiva) e quanto maior a carga viral, menores os escores de qualidade de vida (correlação negativa).

$\mathrm{Na}$ faixa etária de 12 a 20 anos houve correlação positiva e acima de 0,30 entre o escore de Utilização dos Serviços de Saúde e CD4 e também entre o de Sintomas ou Sinais e CD4 (Tabela 19). Com relação à carga viral, os coeficientes de correlação foram negativos e superiores a 0,30 entre carga viral e Avaliação Geral da Saúde, carga viral e Saúde Psicológica e carga viral e Utilização dos Serviços de Saúde (Tabela 19). Houve correlação negativa e estatisticamente significativa entre Sintomas ou Sinais e carga viral $(\mathrm{r}=0,71 ; \mathrm{p}=0,006)$, mostrando claramente que com o aumento da carga viral há uma piora nos escores de Sintomas ou Sinais nessa faixa etária (Tabela 19). 
Tabela 19: Coeficiente de correlação de Spearman (r) entre os escores dos diferentes domínios e a contagem de célula de defesa CD4 e Carga Viral para a faixa etária de 12 a 20 anos. CRT/SP, março 2005.

\begin{tabular}{l|cc}
\hline Domínio & $\frac{\mathbf{C D 4}}{\mathbf{r}(\mathbf{p})}$ & $\frac{12 \text { a } 20 \text { anos }}{(\mathbf{n = 1 3})}$ \\
& $-0,21(0,363)$ & $-0,34(0,258)$ \\
Avaliação Geral da Saúde & - & - \\
Resistência Física & $0,09(0,709)$ & $-0,27(0,382)$ \\
Estado Físico & $-0,15(0,534)$ & $-0,34(0,252)$ \\
Saúde Psicológica & $0,13(0,594)$ & $-0,29(0,340)$ \\
Atividades Pessoais e Sociais & $0,39(0,094)$ & $-0,39(0,191)$ \\
Utilização Serviços de Saúde & $0,34(0,146)$ & $-0,71(0,006)$ \\
\hline
\end{tabular}




\section{Correlação com a Utilização dos Serviços de Saúde}

Na faixa etária de 12 a 20 anos quase todas as correlações entre os domínios e número de noites e visitas ao serviço nas últimas 4 semanas foram negativas (Tabela 20). Obteve-se coeficiente de correlação acima de 0,30 entre a Avaliação Geral da Saúde $(r=-0,36 ; p=0,121)$, o Estado Físico $(r=-0,39 ; p=0,094)$, Sintomas ou Sinais $(r=-0,31$; $\mathrm{p}=0,177$ ) e o número de noites no hospital. As correlações foram estatisticamente significativas entre Atividades Pessoais e Sociais $(r=-0,49 ; p=0,028)$, Utilização dos Serviços de Saúde $(r=-0,52 ; p=0,019)$ e o número de noites no hospital. Houve correlação estatisticamente significativa entre a Avaliação Geral da Saúde ( $r=-0,47$; $\mathrm{p}=0,039)$ e Utilização dos Serviços de Saúde $(r=-0,56 ; \mathrm{p}=0,011)$ e o número de visitas ao serviço. A correlação entre as visitas ao serviço e os Sintomas ou Sinais foi negativa e maior que 0,40 sendo essa correlação bem próxima da significância estatística (Tabela 20).

Tabela 20: Coeficientes de correlação de Spearman (r) entre os escores dos diferentes domínios e marcadores de Utilização dos Serviços de Saúde - noites no hospital e visitas ao médico no último mês para a faixa etária de 12 a 20 anos. CRT/SP, março 2005.

\begin{tabular}{l|cc}
\hline Domínio & $\frac{\text { Noites }}{\mathbf{r}(\mathbf{p})}$ & $\frac{\text { Visitas }}{\mathbf{r}(\mathbf{p})}$ \\
\hline Avaliação Geral da Saúde & $-0,36(0,121)$ & $-0,47(0,039)$ \\
Resistência Física & - & - \\
Estado Físico & $-0,39(0,094)$ & $-0,20(0,389)$ \\
Saúde Psicológica & $0,20(0,379)$ & $-0,06(0,819)$ \\
Atividades Pessoais e Sociais & $-0,49(0,028)$ & $-0,14(0,565)$ \\
Utilização Serviços de Saúde & $-0,52(0,019)$ & $-0,56(0,011)$ \\
Sintomas ou Sinais & $-0,31(0,177)$ & $-0,41(0,074)$ \\
\hline
\end{tabular}




\subsection{Reprodutibilidade}

A Tabela 21 mostra a comparação dos escores de qualidade de vida entre os dois momentos da pesquisa. Na faixa etária de 12 a 20 anos, não houve diferença estatisticamente significativa nas médias dos escores dos domínios, quando se considera o teste e o reteste. Observa-se que, apenas nos domínios de Atividades Pessoais e Sociais e Utilização dos Serviços de Saúde não houve correlação significativa entre os dois momentos (teste e reteste) para a faixa etária em questão. Os demais domínios, apresentaram valores significativos entre 0,58 a 0,93 da correlação intraclasse.

Tabela 21: Comparação teste-reteste entre os escores nos domínios e faixa etária de 12 a 20 anos e coeficientes de correlação intraclasse $\left(r_{\text {icc}}\right)$. CRT/SP, março 2005.

\begin{tabular}{l|lll|ll}
\hline \multirow{2}{*}{ Domínio } & \multicolumn{5}{|c}{ 12 a 20 anos (n=13) } \\
& Teste & Reteste & p & rice & p \\
\hline Avaliação Geral da Saúde & $84,6(12,3)$ & $84,8(12,4)$ & 0,944 & 0,62 & 0,023 \\
Estado Físico & $86,9(28,5)$ & $85,6(28,8)$ & 0,669 & 0,93 & $<0,001$ \\
Saúde Psicológica & $68,5(15,6)$ & $70,5(13,4)$ & 0,350 & 0,89 & $<0,001$ \\
Atividades Pessoais e Sociais & $82,6(12,6)$ & $84,1(14,3)$ & 0,783 & $-0,06$ & 0,838 \\
Utilização Serviços de Saúde & $92,3(6,7)$ & $93,5(7,4)$ & 0,568 & 0,47 & 0,102 \\
Sintomas ou Sinais & $89,9(9,9)$ & $91,2(11,1)$ & 0,657 & 0,58 & 0,040 \\
\hline
\end{tabular}


Análise da reprodutibilidade dos escores de qualidade de vida utilizando o gráfico de Bland Altman para a faixa etária de 12 a 20 anos.

Na faixa etária de 12 a 20 anos, os escores de quase todos os domínios do questionário de qualidade de vida apresentaram boa concordância, pelo gráfico de Bland-Altman. Os escores apresentaram boa distribuição aleatória ao redor do zero, com poucos pontos fora do limite, com exceção do domínio de Estado Físico, (Figuras 16 a 21).

Figura 16: Avaliação Geral da Saúde - Bland Altman (12-20 anos).

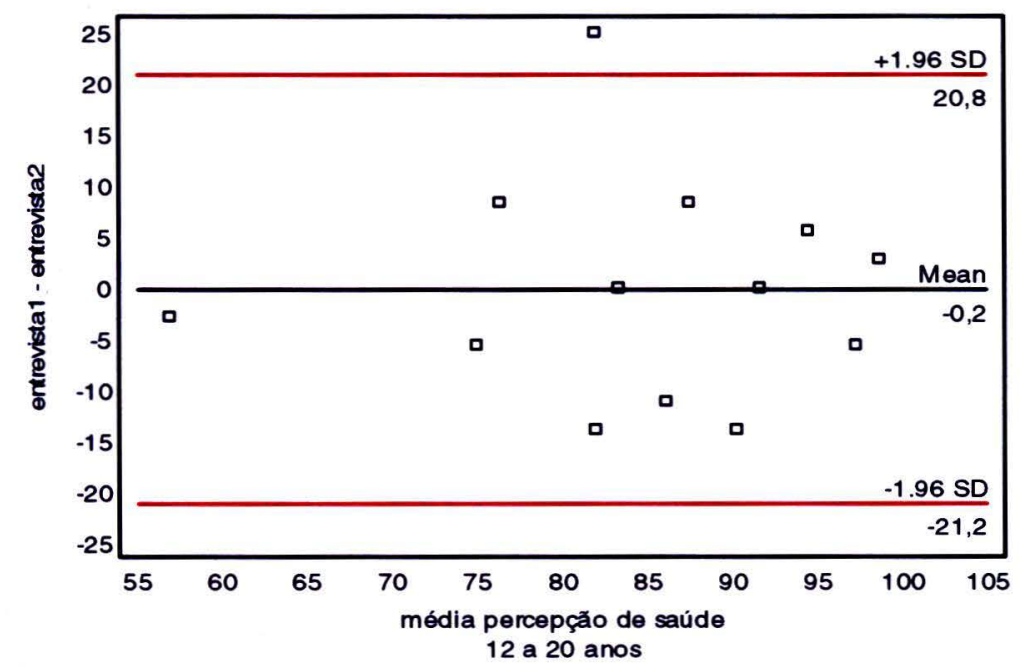

Figura 17: Estado Físico - Bland Altman (12-20 anos).

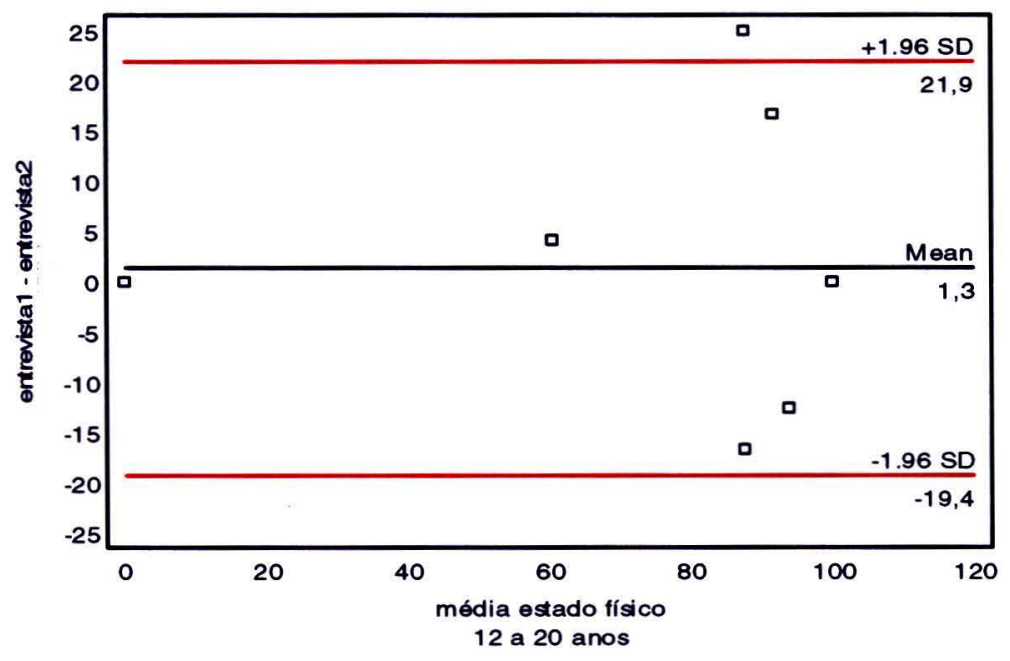


Figura 18: Avaliação da Saúde Psicológica - Bland Altman (12-20 anos).

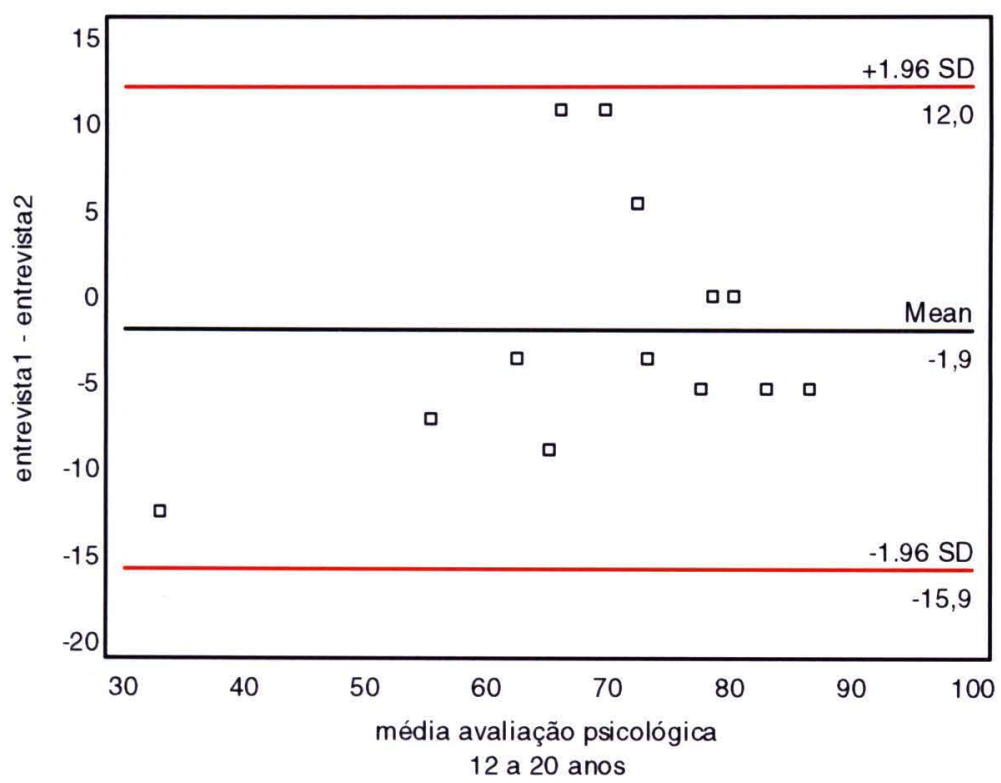

Figura 19: Atividades Pessoais e Sociais - Bland Altman (12-20 anos).

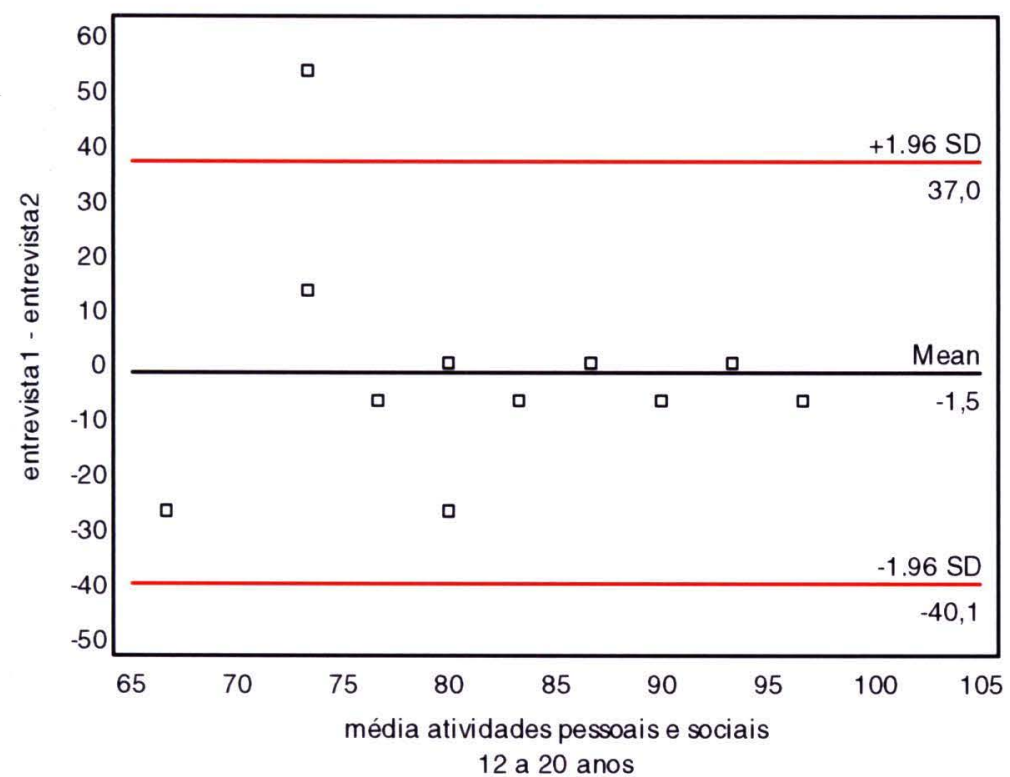


Figura 20: Utilização dos Serviços de Saúde - Bland Altman (12-20 anos).

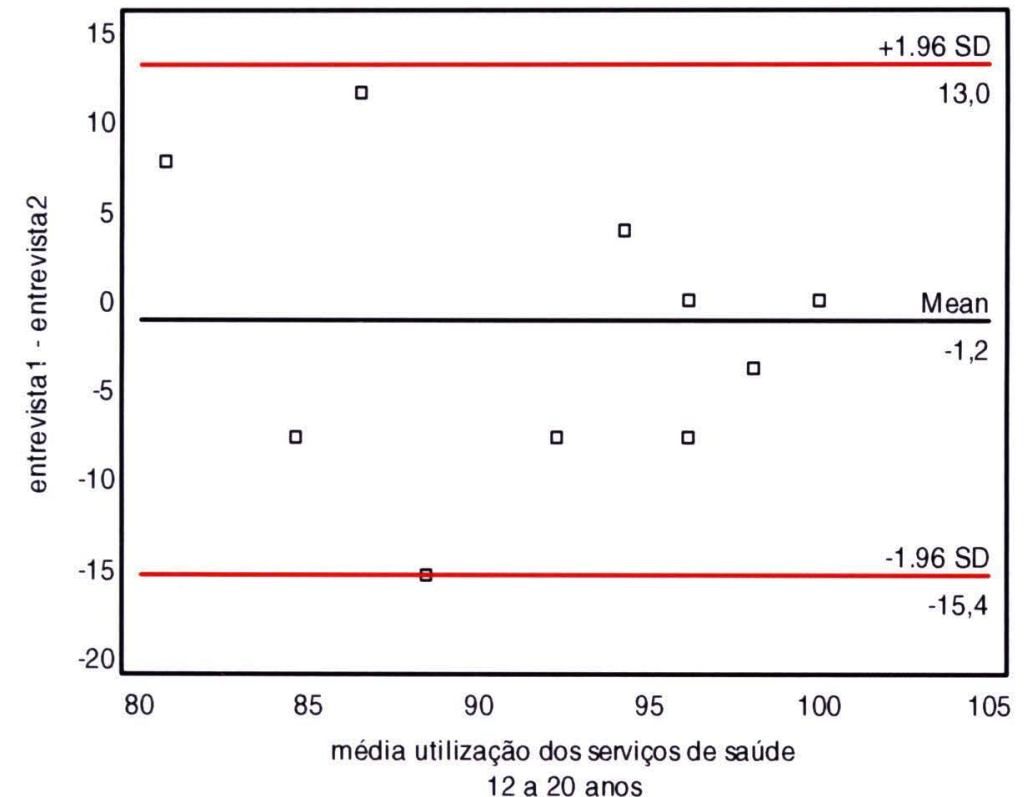

Figura 21: Sintomas ou Sinais - Bland Altman (12-20 anos).

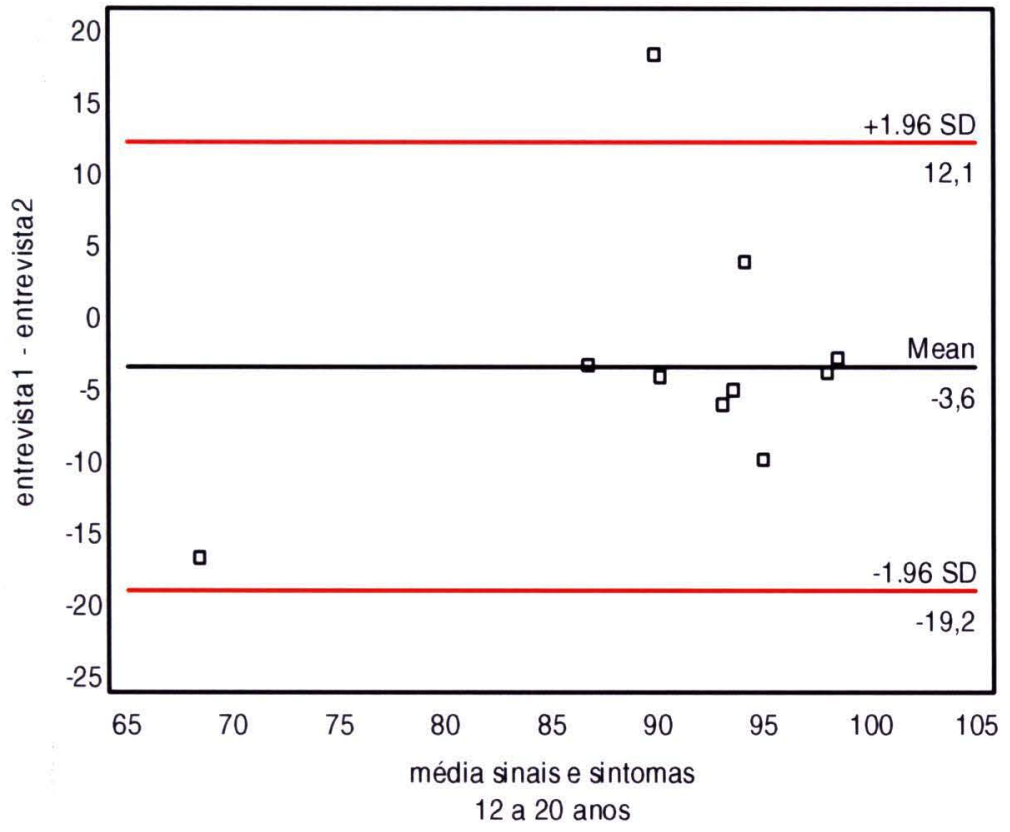




\subsection{ANÁLISE GRÁFICA ENTRE O TESTE E O RETESTE DO QUESTIONÁRIO DE QUALIDADE DE VIDA, COMPARANDO AS TRÊS} FAIXAS ETÁRIAS

A Figura 22 mostra as médias do escore de Avaliação Geral da Saúde e seus respectivos intervalos de confiança nos dois momentos (teste-reteste), para as três faixas etárias estudadas. Observa-se que as médias do escore são muito próximas (uma está dentro do intervalo de confiança da outra e vice-versa) nos dois momentos estudados, para as três faixas etárias. Na Figura 23 pode-se observar a existência de uma relação linear entre os valores dos escores de Avaliação Geral da Saúde nos dois momentos estudados, para as três faixas etárias.

Figura 22: Médias e respectivos intervalos de $95 \%$ de confiança do domínio Avaliação Geral da Saúde nas duas entrevistas, segundo faixa etária.

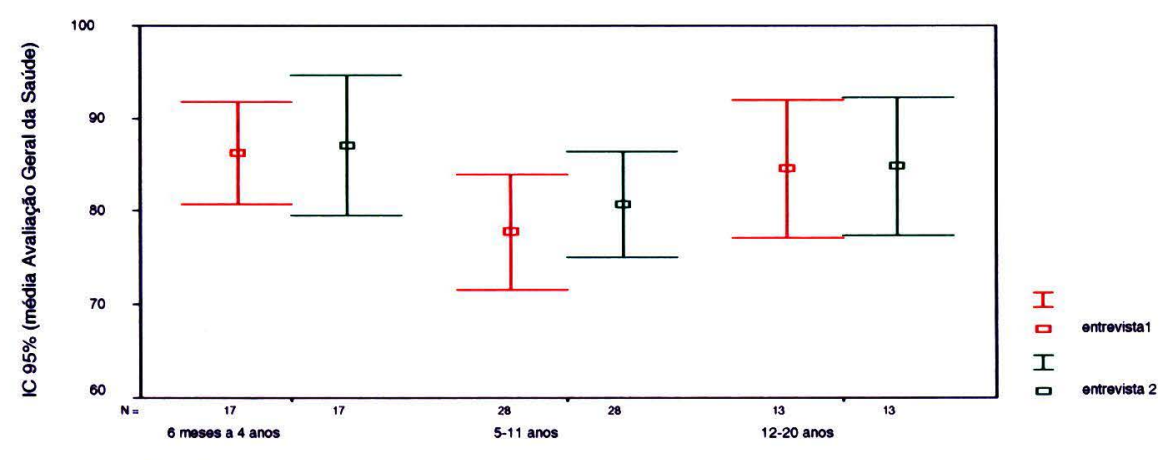

faixa etária

Figura 23. Diagrama de dispersão entre os valores do domínio de Avaliação Geral da Saúde nas duas entrevistas, segundo faixa etária.

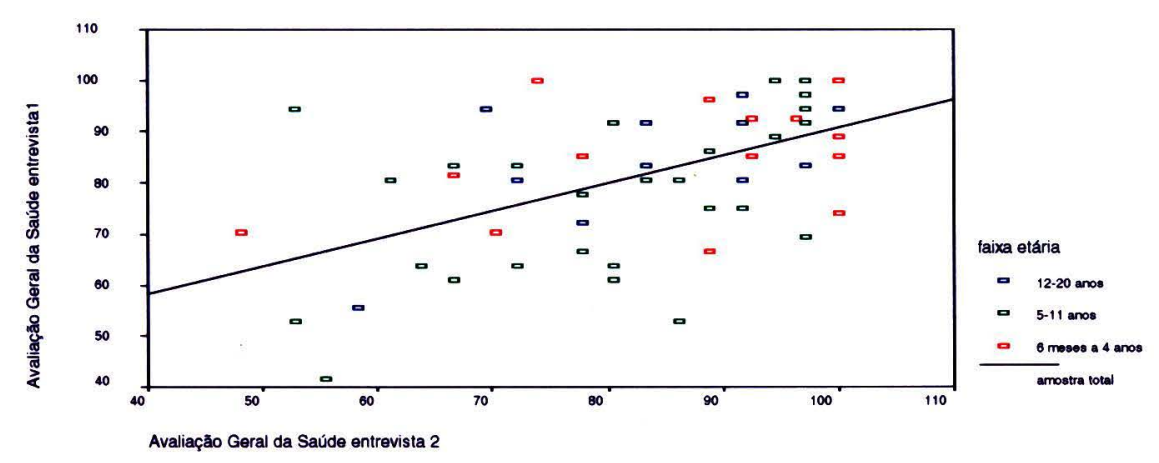


A Figura 24 mostra a proximidade das médias dos escores de Resistência Física nos dois momentos para as faixas etárias de 6 meses a 4 anos e também para aquela de 5 a 11 anos. A Figura 25 evidencia a presença de uma relação linear entre os valores do escore de Resistência Física nos dois momentos, para as faixas de 6 meses a 4 anos e para a de 5 a 11 anos.

Figura 24: Médias e respectivos intervalos de 95\% de confiança do domínio Resistência Física nas duas entrevistas, segundo faixa etária.

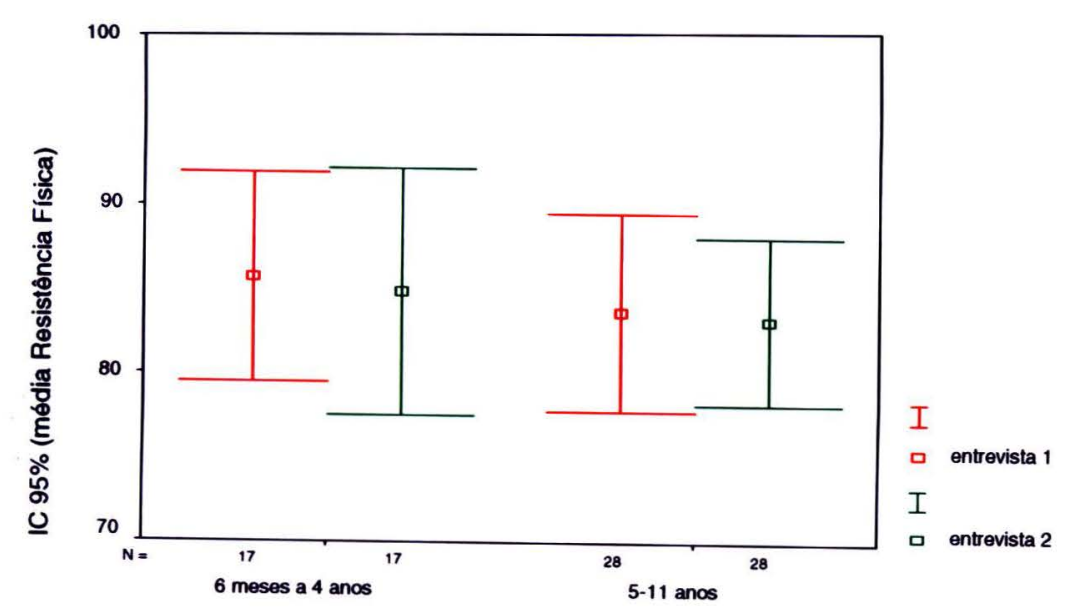

faixa etária

Figura 25: Diagrama de dispersão entre os valores do domínio Resistência Física nas duas entrevistas, segundo faixa etária.

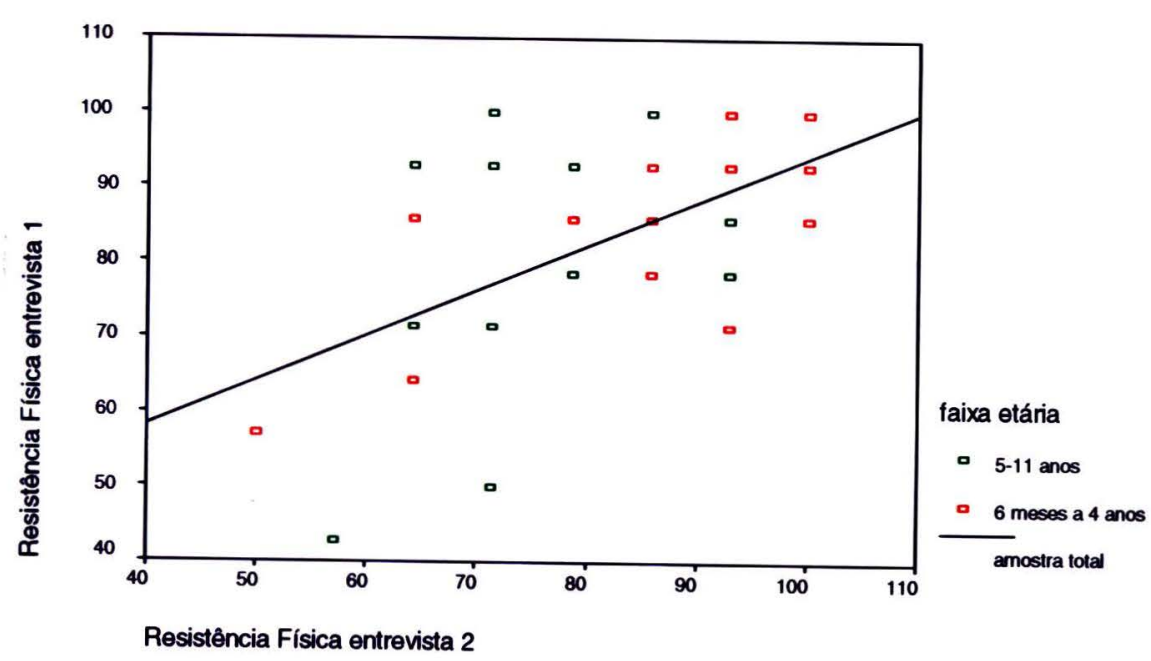


Na Figura 26 observa-se que as médias do escore de Estado Físico são semelhantes nos dois momentos para as faixas etárias de 6 meses a 4 anos e 12 a 20 anos; para a faixa etária de 5 a 11 anos as médias do escore estão mais distantes uma da outra (uma está fora do intervalo de confiança da outra) nos dois momentos, mostrando a diferença de médias do escore de Estado Físico no teste-reteste. Pelo diagrama de dispersão (Figura 27) verifica-se a presença de relação linear entre os valores do escore de Estado Físico no teste e no reteste, para as três faixas estudadas. Observa-se também alguns pontos que podem ser valores extremos.

Figura 26: Médias e respectivos intervalos de $95 \%$ de confiança do domínio Estado Físico nas duas entrevistas, segundo faixa etária.

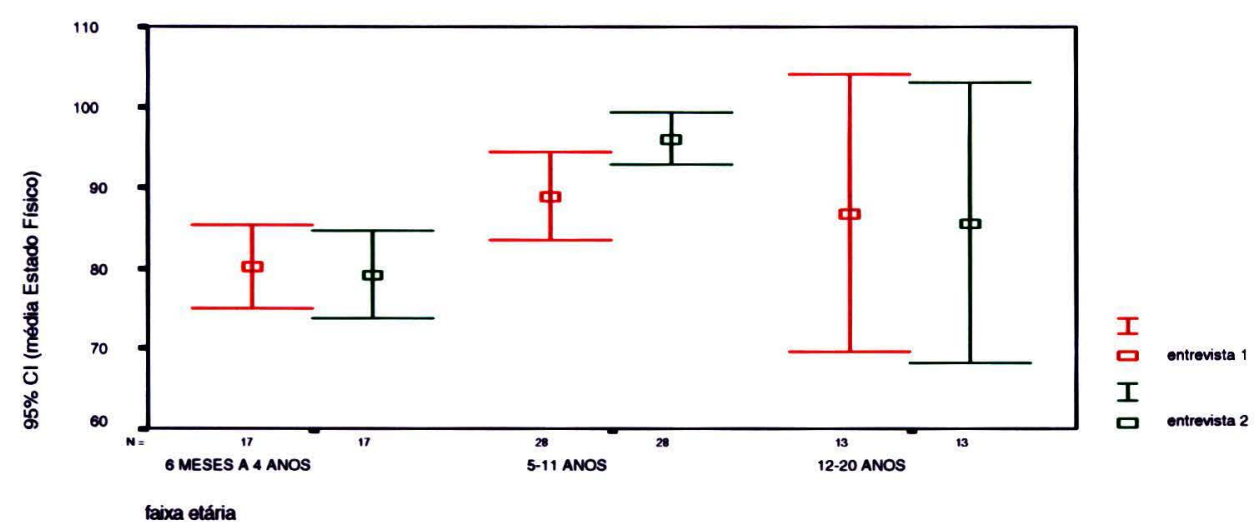

Figura 27: Diagrama de dispersão entre os valores do domínio Estado Físico nas duas entrevistas, segundo faixa etária.

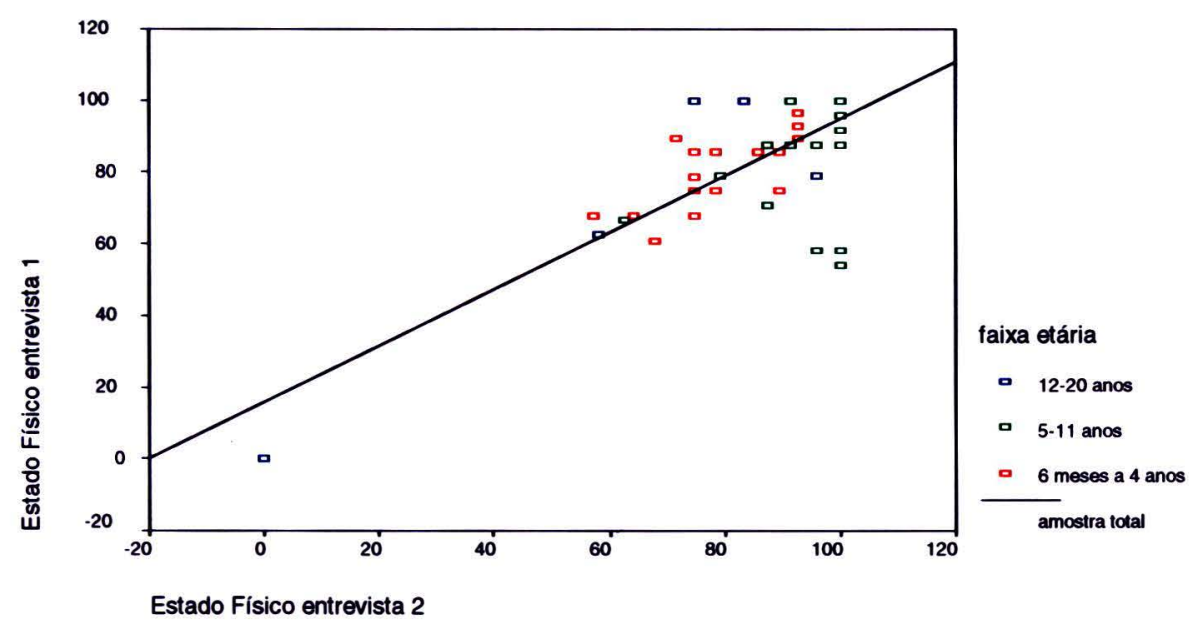


A Figura 28 mostra a semelhança das médias do escore de Avaliação da Saúde Psicológica nos dois momentos da pesquisa, para as faixas de 5 a 11 e 12 a 20 anos. Pelo diagrama de dispersão (Figura 29) verifica-se a presença de relação linear entre os valores dos escores no teste e no reteste, para as duas faixas etárias.

Figura 28: Médias e respectivos intervalos de 95\% de confiança do domínio Avaliação da Saúde Psicológica nas duas entrevistas, segundo faixa etária.

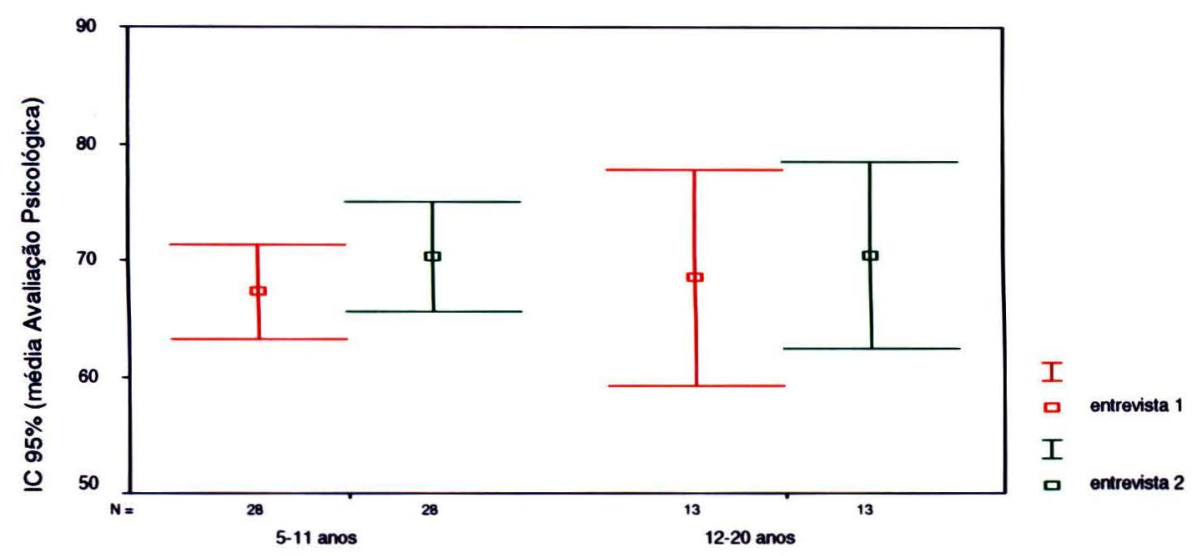

faixa etária

Figura 29: Diagrama de dispersão entre os valores do domínio Avaliação da Saúde Psicológica nas duas entrevistas, segundo faixa etária.

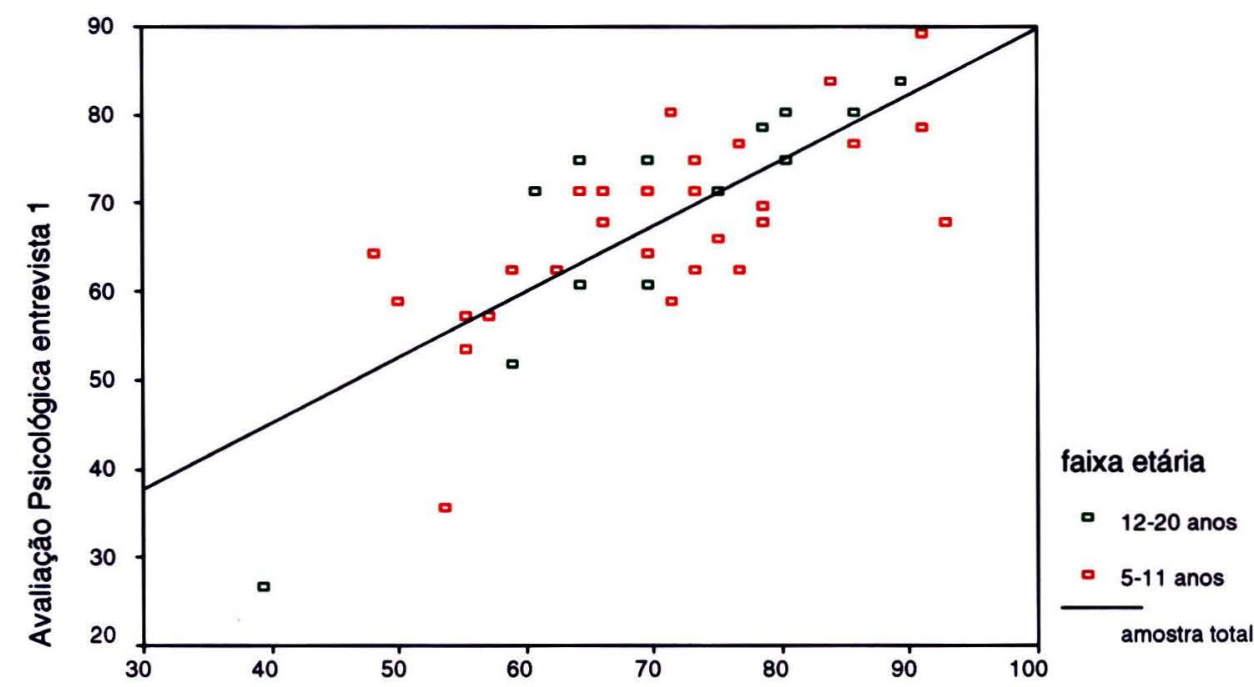

Avaliação Psicológica entrevista 2 
Na Figura 30 observa-se que as médias do escore de Avaliação das Atividades Pessoais e Sociais são semelhantes no teste e no reteste para as três faixas etárias estudadas. O diagrama de dispersão (Figura 31) mostra a ausência de relação linear entre os valores dos escores no teste e no reteste para as três faixas etárias estudadas.

Figura 30: Médias e respectivos intervalos de $95 \%$ de confiança do domínio Atividades Pessoais e Sociais nas duas entrevistas, segundo faixa etária.

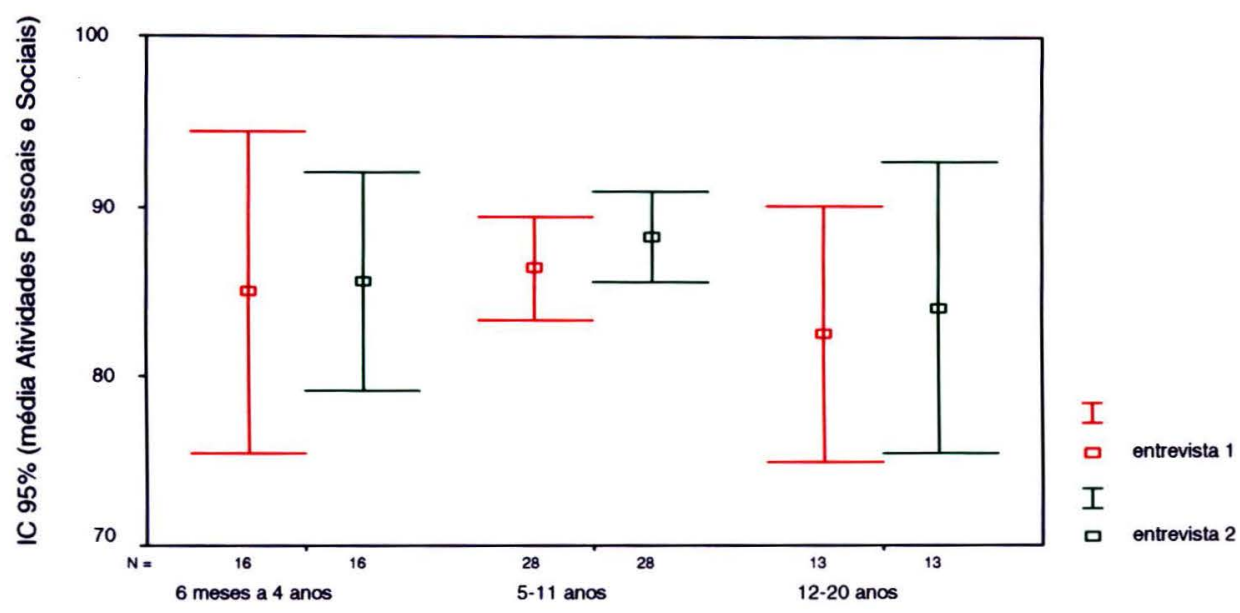

faixa etária

Figura 31: Diagrama de dispersão entre os valores do domínio Atividades Pessoais e Sociais nas duas entrevistas, segundo faixa etária.

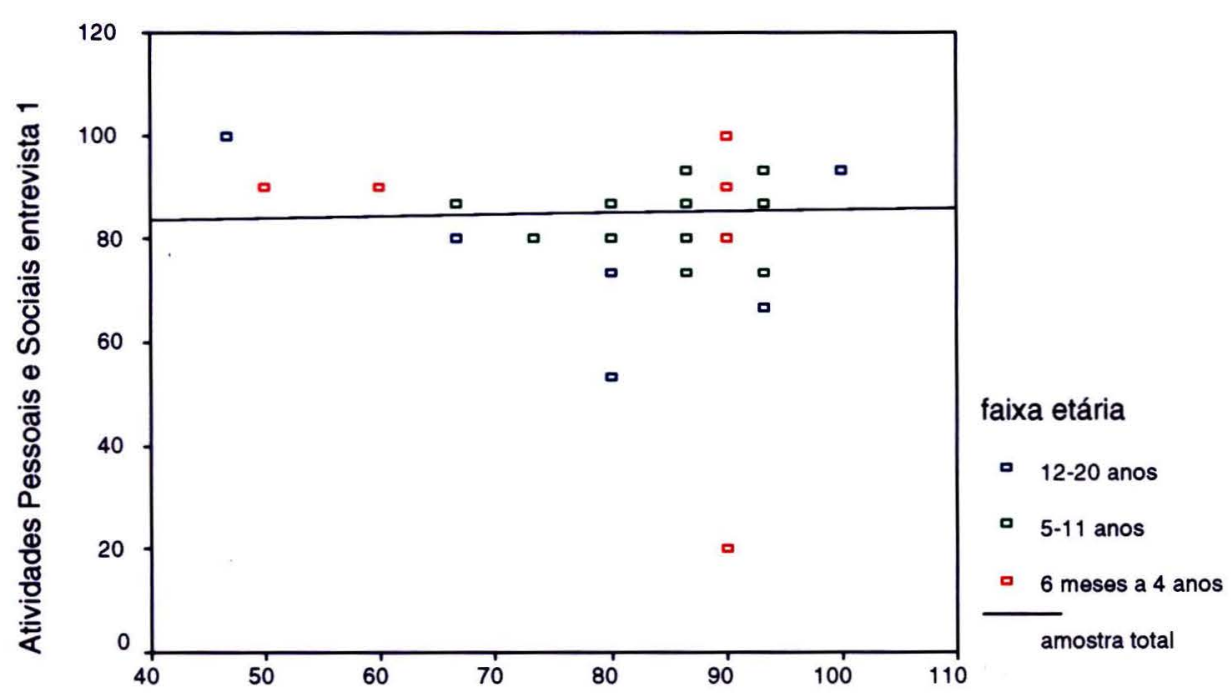

Atividades Pessoais e Sociais entrevista 2 
Pela Figura 32 pode-se verificar que as médias do escore de Utilização dos Serviços de Saúde são semelhantes nos dois momentos para as três faixas etárias. Na Figura 33 pode-se perceber a quase ausência de relação linear entre os valores do escore nos dois momentos.

Figura 32: Médias e respectivos intervalos de $95 \%$ de confiança do domínio Utilização dos Serviços de Saúde nas duas entrevistas, segundo faixa etária.

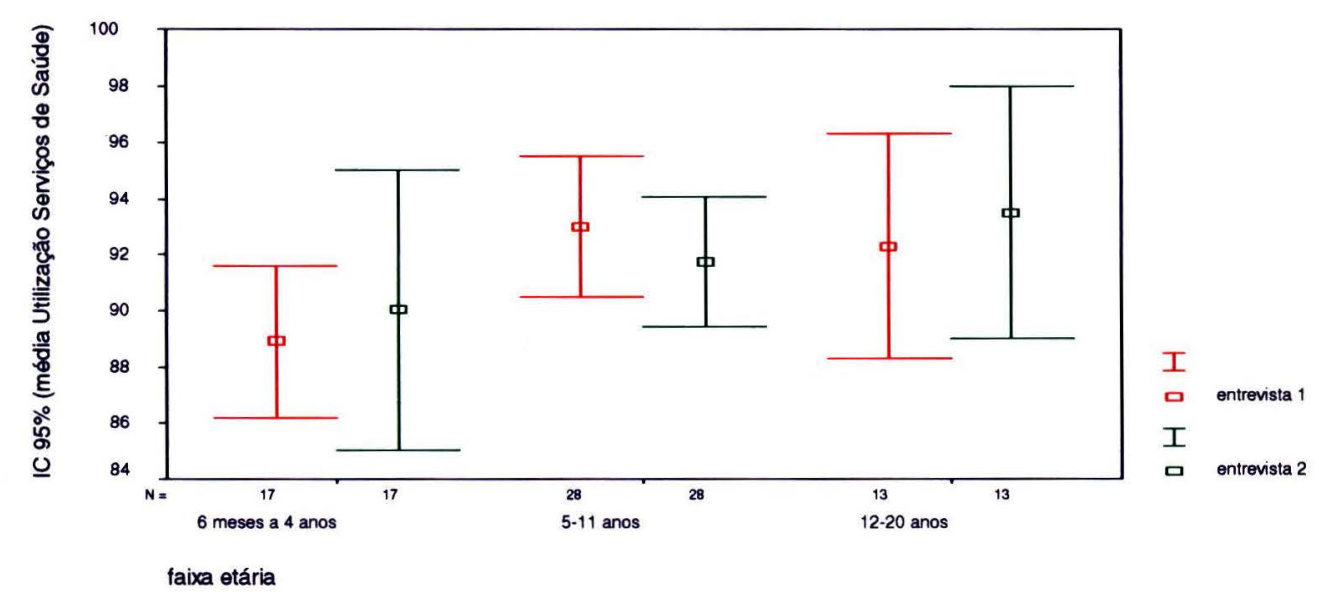

Figura 33: Diagrama de dispersão entre os valores do domínio Utilização dos Serviços de Saúde nas duas entrevistas, segundo faixa etária.

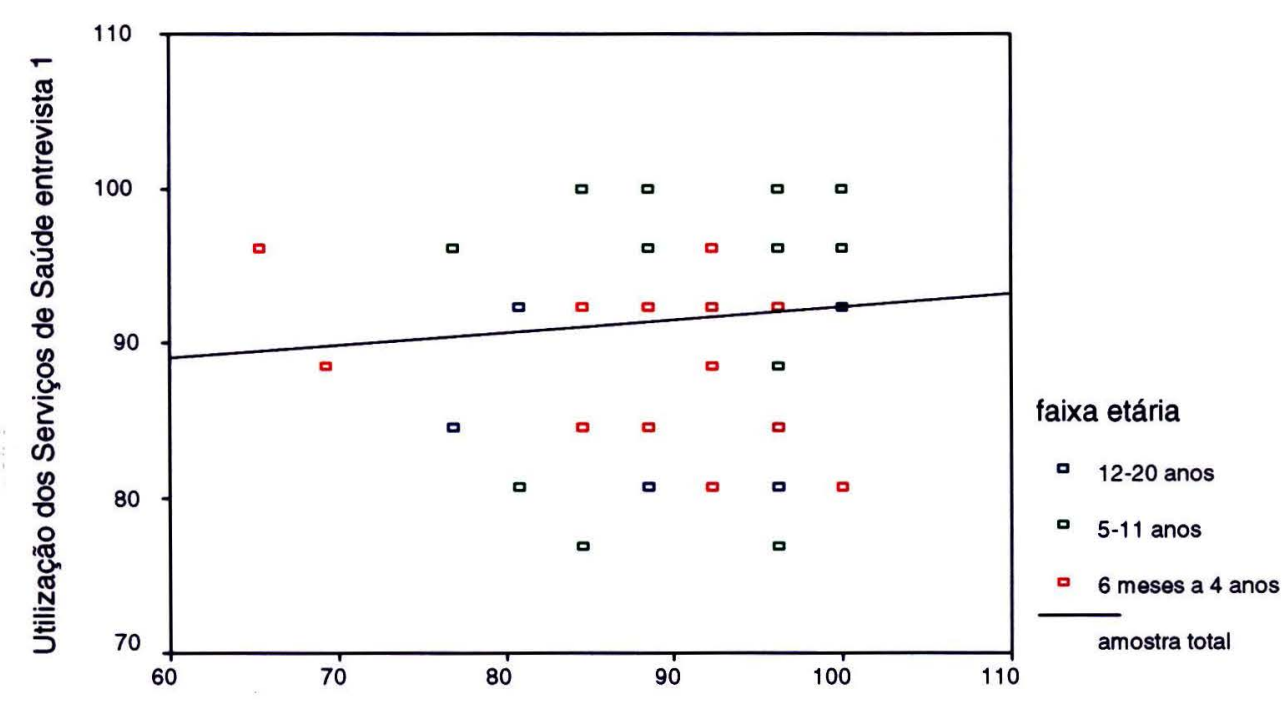

Utilização dos Serviços de Saúde entrevista 2 
Para as faixas de 6 meses a 4 anos e também para a de 5 a 11 anos verifica-se que as médias do escore de Sintomas ou Sinais nos dois momentos são semelhantes (Figura 34); já para a faixa etária de 5 a 11 anos observa-se que as médias do escore estão mais distantes (e uma está fora do intervalo de confiança da outra) evidenciando que elas não foram semelhantes nos dois momentos da pesquisa. Pela Figura 35 observa-se a presença de relação linear entre os valores do escore de Sintomas ou Sinais nos dois momentos para as três faixas etárias estudadas.

Figura 34: Médias e respectivos intervalos de $95 \%$ de confiança do domínio Sintomas ou Sinais nas duas entrevistas, segundo faixa etária.

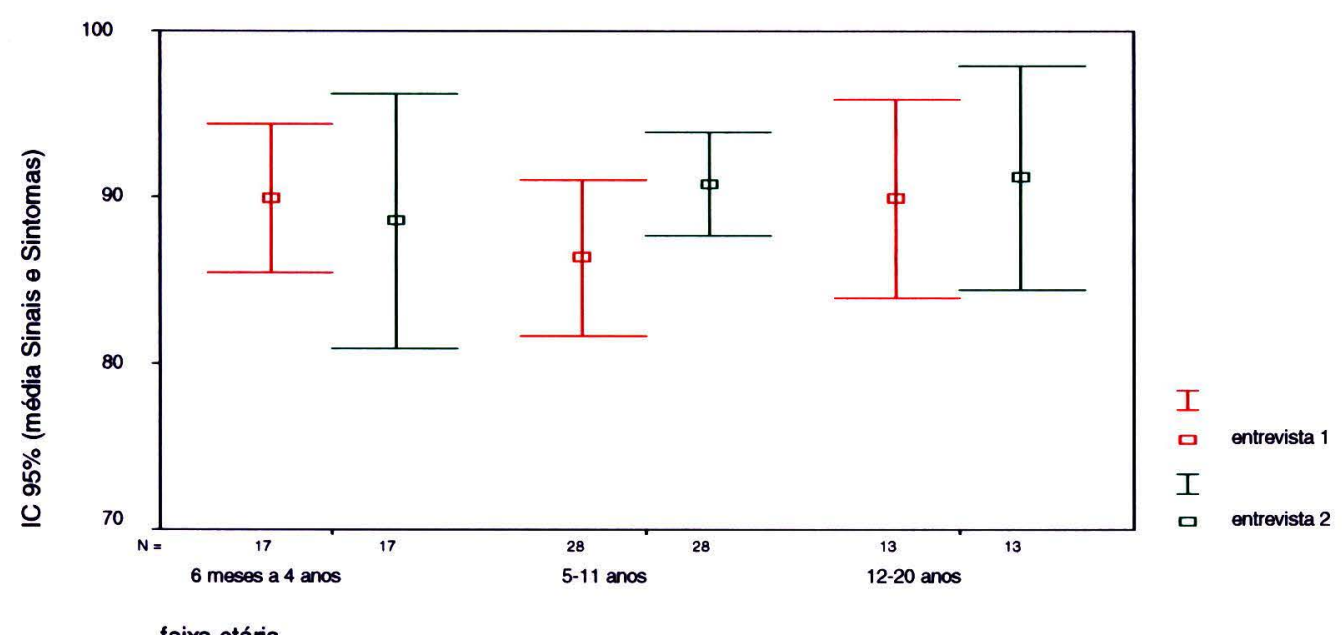

Figura 35: Diagrama de dispersão entre os valores do domínio Sintomas ou Sinais nas duas entrevistas, segundo faixa etária.

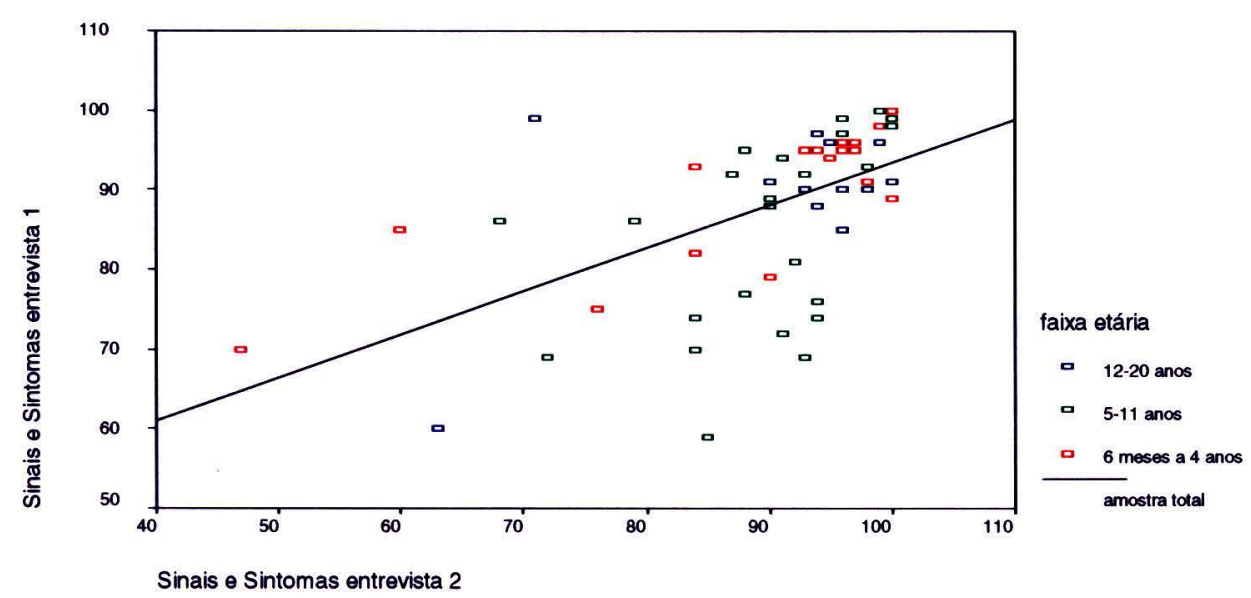




\subsection{QUESTIONÁRIO DE AUTO-EFICÁCIA}

A amostra total de crianças com HIV/Aids que estava tomando medicamentos anti-retrovirais no momento da entrevista foi de 54 crianças. Vale dizer que, para a faixa etária de 6 meses a 4 anos, das 4 crianças com diagnóstico de Aids, 3 delas estavam tomando os medicamentos anti-retrovirais, no momento da pesquisa.

\subsubsection{Equivalência de mensuração}

\subsubsection{Consistência Interna}

A consistência interna da escala foi alta para o total da amostra e também para as faixas etárias estudadas (Tabela 22). $\mathrm{O}$ teste de aderência à curva Normal evidenciou que tanto o escore-1 de auto-eficácia como o escore- 2 não têm distribuição Normal ( $p=0,005$ $\mathrm{e} p=0,017$, respectivamente). 
Tabela 22: Consistência interna do questionário de auto-eficácia para seguir prescrição anti-retroviral segundo faixa etária. CRT/SP, março 2005.

\begin{tabular}{|c|c|c|c|c|c|}
\hline Faixa Etária & $\mathbf{n}$ & Média (dp) & Mediana & Min-Max & a Cronbach \\
\hline \multicolumn{6}{|l|}{ Escore-1 } \\
\hline 6 meses a 4 anos & 3 & $0,02(1,20)$ & 0,72 & $-1,37-0,72$ & 0,99 \\
\hline 5 a 11 anos & 31 & $0,08(1,04)$ & 0,59 & $-4,11-0,72$ & 0,89 \\
\hline 12 a 20 anos & 20 & $-0,13(0,95)$ & 0,18 & $-2,39-0,72$ & 0,86 \\
\hline Total amostra & 54 & $0,00(1,00)$ & $\mathbf{0 , 3 3}$ & $-4,11-0,72$ & $\mathbf{0 , 8 7}$ \\
\hline \multicolumn{6}{|l|}{ Escore-2 } \\
\hline 6 meses a 4 anos & 3 & $92,06(13,75)$ & 100,00 & $76,19-100,00$ & 0,99 \\
\hline 5 a 11 anos & 31 & $90,63(13,27)$ & 97,62 & $47,62-100,00$ & 0,89 \\
\hline 12 a 20 anos & 20 & $88,63(11,36)$ & 91,67 & $64,29-100,00$ & 0,86 \\
\hline Total amostra & 54 & $89,97(12,42)$ & 94,05 & $47,62-100,00$ & 0,87 \\
\hline
\end{tabular}




\subsubsection{Análise Fatorial Exploratória}

Foi realizada a análise fatorial exploratória para o cálculo do escore-1 de autoeficácia pela extração do primeiro componente principal a partir do método de regressão. Selecionou-se um único fator que explicou $31,34 \%$ da variância acumulada (Tabela 23). O escore-1 foi calculado a partir dos coeficientes de regressão listados na Tabela 23. Como esse escore foi padronizado, ele pode variar de -1 a 1. 
Tabela 23: Resultados da análise fatorial do escore de auto-eficácia. CRT/SP, março 2005.

\begin{tabular}{|c|c|c|}
\hline Itens da escala & Fator 1 & $\begin{array}{l}\text { Coeficientes de } \\
\text { Regressão }\end{array}$ \\
\hline Se a criança/adolescente estiver bem de saúde. & 0,490 & 0,075 \\
\hline Se o vírus no sangue da criança/adolescente for tão pouco que não aparece na carga viral. & 0,718 & 0,109 \\
\hline Se a criança/adolescente estiver aborrecida e se sentindo pra baixo. & 0,719 & 0,109 \\
\hline Se a criança/adolescente for discriminada ou rejeitada. & não foi & selecionado \\
\hline Se a criança/adolescente estiver ocupada ou se divertindo. & não foi & selecionado \\
\hline Se a criança/adolescente estiver em viagem de passeio ou de trabalho. & 0,476 & 0,072 \\
\hline Se a criança/adolescente estiver na rua. & 0,688 & 0,104 \\
\hline Se a criança/adolescente estiver se sentindo doente. & 0,632 & 0,096 \\
\hline $\begin{array}{l}\text { Se a criança/adolescente estiver com alguém que você não quer que saiba que ela é portadora do } \\
\text { vírus da AIDS }\end{array}$ & 0,703 & 0,107 \\
\hline Se a criança/adolescente tiver de tomar muitos comprimidos. & não foi & selecionado \\
\hline Se a criança/adolescente estiver nervosa ou irritada. & 0,683 & 0,104 \\
\hline Se a criança/adolescente mudar muito de médico que a atende. & 0,567 & 0,086 \\
\hline Se a criança/adolescente tiver de tomar remédios várias vezes por dia. & não foi & selecionado \\
\hline Se a criança/adolescente estiver com pessoas estranhas. & 0,758 & 0,115 \\
\hline Se o remédio for difícil de engolir. & 0,549 & 0,083 \\
\hline Se for feriado ou final de semana. & 0,667 & 0,101 \\
\hline Se a criança/adolescente tiver de mudar o horário de comer ou de dormir. & 0,529 & 0,080 \\
\hline Se o remédio tiver gosto ruim ou cheiro forte. & 0,462 & 0,070 \\
\hline Se a criança/adolescente estiver fazendo coisas fora da rotina. & 0,666 & 0,101 \\
\hline Se a criança/adolescente estiver com alguém que acha bobagem tomar esses remédios. & não foi & selecionado \\
\hline Se os remédios estiverem causando efeito ruim. & 0,677 & 0,103 \\
\hline \% da variância acumulada & 31,341 & - \\
\hline$\alpha$ Cronback com todos os itens/questões & 0,875 & - \\
\hline
\end{tabular}




\subsubsection{Validação}

\section{Validade de Constructo}

\section{Comparação de médias}

Foi realizada a comparação dos escores 1 e 2 de auto-eficácia entre os grupos de crianças aderentes e não aderentes ao esquema ou tratamento anti-retroviral. Foram considerados aderentes os pacientes que estivessem usando, nos 3 últimos dias, $95 \%$ ou mais das doses prescritas no esquema anti-retroviral e não aderentes, aqueles cuja porcentagem mostrou-se inferior a $95 \%$. Nessa análise espera-se encontrar os maiores escores de auto-eficácia no grupo de crianças/adolescentes que são aderentes ao tratamento anti-retroviral.

$\mathrm{Na}$ faixa etária de 6 meses a 4 anos não foi realizada a comparação dos grupos, pois no grupo de crianças não-aderentes havia somente uma criança, o que torna a análise estatística inviável.

$\mathrm{Na}$ faixa etária de 5 a 11 anos houve diferença estatisticamente significativa nas médias dos grupos de crianças aderentes quando comparado com o de crianças não aderentes, para o escore-1 de $\mathrm{AE}(0,23 \times-1,37 ; \mathrm{p}=0,046)$. Embora a média do escore-2 tenha sido maior no grupo de crianças aderentes, a diferença ficou no limite da significância estatística $(92,30 \times 75,00 ; \mathrm{p}=0,063)$ (Tabela 24$)$.

Na faixa etária de 12 a 20 anos não houve diferença estatisticamente significativa na média do grupo aderente quando comparado com o grupo não aderente, tanto para o escore- 1 de $\operatorname{AE}(0,05 \times-0,66 ; p=0,104)$ como para o escore- $2(91,03 \times 81,43 ; p=0,086)$ (Tabela 24).

Analisando todas as crianças, verificou-se que as médias dos escores 1 e 2 de auto-eficácia foram maiores para o grupo aderente ao tratamento quando comparado com o grupo não aderente e as diferenças entre os grupos foram estatisticamente 
significativas $(0,20 \times-0,97 ; p=0,002$ para o escore- 1 e $92,22 \times 78,70 ; p=0,002$ para o escore-2).

Esses achados sugerem que, as crianças/adolescentes aderentes ao tratamento anti-retroviral têm maior expectativa de auto-eficácia do que aqueles não aderentes.

Tabela 24: Comparação de médias dos escores de auto-eficácia em relação aos aderentes e não aderentes ao tratamento anti-retroviral. CRT/SP, março 2005.

\begin{tabular}{|c|c|c|c|c|}
\hline Faixa Etária & Grupo & $\mathbf{n}$ & Média (dp) & $\mathbf{p}^{*}$ \\
\hline $\begin{array}{l}\text { Escore-1 } \\
5 \text { a } 11 \text { anos }\end{array}$ & $\begin{array}{l}\text { Aderente } \\
\text { Não aderente }\end{array}$ & $\begin{array}{c}28 \\
3\end{array}$ & $\begin{array}{c}0,23(0,73) \\
-1,37(2,38)\end{array}$ & 0,046 \\
\hline 12 a 20 anos & $\begin{array}{l}\text { Aderente } \\
\text { Não aderente }\end{array}$ & $\begin{array}{c}15 \\
5\end{array}$ & $\begin{array}{r}0,05(0,87) \\
-0,66(1,06)\end{array}$ & 0,104 \\
\hline Total amostra & $\begin{array}{l}\text { Aderente } \\
\text { Não aderente }\end{array}$ & $\begin{array}{l}45 \\
9\end{array}$ & $\begin{array}{r}0,20(0,77) \\
-0,97(1,45)\end{array}$ & 0,002 \\
\hline $\begin{array}{l}\text { Escore-2 } \\
5 \text { a } 11 \text { anos }\end{array}$ & $\begin{array}{l}\text { Aderente } \\
\text { Não aderente }\end{array}$ & $\begin{array}{c}28 \\
3\end{array}$ & $\begin{array}{l}92,30(11,13) \\
75,00(23,78)\end{array}$ & 0,063 \\
\hline 12 a 20 anos & $\begin{array}{l}\text { Aderente } \\
\text { Não aderente }\end{array}$ & $\begin{array}{c}15 \\
5\end{array}$ & $\begin{array}{l}91,03(10,75) \\
81,43(11,06)\end{array}$ & 0,086 \\
\hline Total amostra & \begin{tabular}{|l} 
Aderente \\
Não aderente \\
\end{tabular} & $\begin{array}{c}45 \\
9\end{array}$ & $\begin{array}{l}92,22(10,77) \\
78,70(14,60)\end{array}$ & 0,002 \\
\hline
\end{tabular}

p*: Teste de Mann-Whitney 


\section{Correlação com contagem de células de defesa CD4 e carga viral}

Os escores 1 e 2 de AE foram correlacionados com as características clínicas contagem de células de defesa CD4 e carga viral, trabalhadas com a transformação logarítmica. Nessa análise espera-se que as crianças com os melhores escores 1 e 2 de auto-eficácia tenham melhores níveis de CD4 (correlação positiva) e menores níveis de carga viral (correlação negativa).

Não foi feita esta análise para a faixa etária de 6 meses a 4 anos devido ao pequeno número de casos $(n=2)$.

Na faixa etária de 5 a 11 anos, os coeficientes de correlação entre o CD4 e os escores 1 e 2 de auto-eficácia foram positivos e acima de 0,30. A correlação do CD4 com o escore-1 de $\mathrm{AE}$ ficou próxima da significância estatística $(r=0,33 ; \mathrm{p}=0,076)$ enquanto que a correlação com o escore- 2 foi estatisticamente significativa ( $r=0,30$; $\mathrm{p}=0,039)$. Nesse grupo $(\mathrm{n}=31)$ a análise para a carga viral foi realizada com 19 pacientes pois 12 deles tiveram carga viral indetectável. Obtiveram-se coeficientes de correlação negativos e superiores a 0,30 entre a carga viral e os escores 1 e 2 de AE sendo que a correlação com o escore-1 $(r=-0,41 ; p=0,083)$ ficou próxima da significância estatística e a correlação com o escore- 2 foi estatisticamente significativa $(r=-0,50 ; p=0,030)$ (Tabela 25). Os resultados para esse grupo de crianças são coerentes, pois quanto maior o escore de $\mathrm{AE}$ espera-se que maior seja a contagem de células de defesa CD4, indicando assim uma boa resposta ao tratamento anti-retroviral; quanto menor o escore de $\mathrm{AE}$ espera-se um aumento da carga viral, mostrando uma piora na resposta ao tratamento.

Na faixa etária de 12 a 20 anos, os coeficientes de correlação entre o CD4 e os escores 1 e 2 de $\mathrm{AE}$ foram próximos a 0 , indicando ausência de relação linear entre eles. Já com relação à carga viral, os coeficientes de correlação com os escores 1 e 2 foram acima de 0,30 e positivos, porém não estatisticamente significativos (Tabela 25). Nesse grupo $(n=20)$ a análise de correlação com a carga viral foi realizada com 13 pacientes, pois 7 deles tiveram carga viral indetectável. A inversão no sinal da correlação com a carga viral não era esperada, pois não faz sentido ter um aumento da carga viral, 
indicando uma má resposta ao tratamento e, também, ter um aumento nos escores de auto-eficácia. Verificou-se que 3 pacientes desse grupo tinham carga viral alta $(96.800$, 116.000 e 241.000 cópias/mm) e escores 1 e 2 de $\mathrm{AE}$ também altos $(0,30,0,72,0,72$; $92,86,100$ e 100, respectivamente), o que fez com que o sinal da correlação ficasse positivo. Quando se exclui esses pacientes, para efeito de verificação do sinal, observase que as correlações da carga viral com os escores 1 e 2 de AE ficam negativas, porém menores que $0,30(r=-0,15 ; p=0,688 ; r=-0,18 ; p=0,625$, respectivamente).

Para o total da amostra $(n=54)$, os coeficientes de correlação entre o CD4 e os escores 1 e 2 foram positivos e próximos a 0,30. A correlação do CD4 com o escore-1 ficou próxima da significância estatística $(r=0,26 ; p=0,061)$, enquanto que a correlação com o escore- 2 foi estatisticamente significativa $(r=0,28 ; p=0,040)$, mostrando o comportamento esperado para essa correlação, ou seja, quanto melhores os escores de auto-eficácia, maiores são as contagens de células de defesa CD4, indicando boa resposta ao tratamento anti-retroviral (Tabela 25). Com relação à carga viral, a análise foi realizada com 34 pacientes, pois 20 deles tiveram carga viral indetectável. Os coeficientes de correlação com os escores 1 e 2 de auto-eficácia apresentaram tendência decrescente (negativos), porém foram inferiores a 0,30 . 
Tabela 25: Coeficiente de correlação de Spearman (r) entre os escores dos diferentes domínios e a contagem de célula de defesa CD4. CRT/SP, março 2005.

\begin{tabular}{l|l|cc}
\hline Faixa Etária & $\mathbf{n}$ & $\mathbf{C D 4}$ & Carga Viral \\
\hline $\begin{array}{l}\text { Escore-1 } \\
5 \text { a } 11 \text { anos }\end{array}$ & 19 & $0,33(0,076)$ & $\mathbf{r}(\mathbf{p})$ \\
12 a 20 anos & 13 & $0,00(0,997)$ & $-0,41(0,083)$ \\
\hline Total amostra & $\mathbf{3 4}$ & $\mathbf{0 , 2 6}(\mathbf{0 , 0 6 1 )}$ & $0,33(0,264)$ \\
\hline \hline Escore-2 & & & $\mathbf{- 0 , 0 7 5 ( \mathbf { 0 , 6 7 4 } )}$ \\
5 a 11 anos & 19 & $0,38(0,039)$ & $-0,50(0,030)$ \\
12 a 20 anos & 13 & $0,01(0,952)$ & $0,32(0,284)$ \\
\hline Total amostra & $\mathbf{3 4}$ & $\mathbf{0 , 2 8 ( 0 , 0 4 0 )}$ & $\mathbf{- 0 , 1 5 ( 0 , 3 9 6 )}$ \\
\hline
\end{tabular}




\subsubsection{Reprodutibilidade}

Foram comparadas as médias dos escores 1 e 2 de $\mathrm{AE}$ na primeira (teste) e na segunda entrevista (reteste), para as faixas etárias e também para o total da amostra, com exceção da faixa etária de 6 meses a 4 anos, devido ao pequeno número de casos $(n=3)$.

Nas faixas etárias, não foram encontradas diferenças estatisticamente significativas nas médias dos escores quando se considera o teste e o reteste, para o escore-1 de auto-eficácia (Tabela 26). Já quando se analisa escore-2, nas faixas etárias não foram observadas diferenças estatisticamente significativas entre o teste e o reteste, porém para a amostra total foi encontrada diferença significativa entre as médias $(89,70$ $\mathrm{x} 92,47 ; \mathrm{p}=0,028)$.

A Tabela 26 também mostra os coeficientes de correlação intraclasse entre os escores 1 e 2 de AE do teste e do reteste. Todos os coeficientes de correlação intraclasse foram maiores que 0,65 e significativos, mostrando boa reprodutibilidade do questionário de auto-eficácia para seguir prescrição anti-retroviral.

Tabela 26: Comparação teste-reteste entre os escores de auto-eficácia e coeficientes de correlação intraclasse ( $\left.r_{i c c}\right)$. CRT/SP, março 2005.

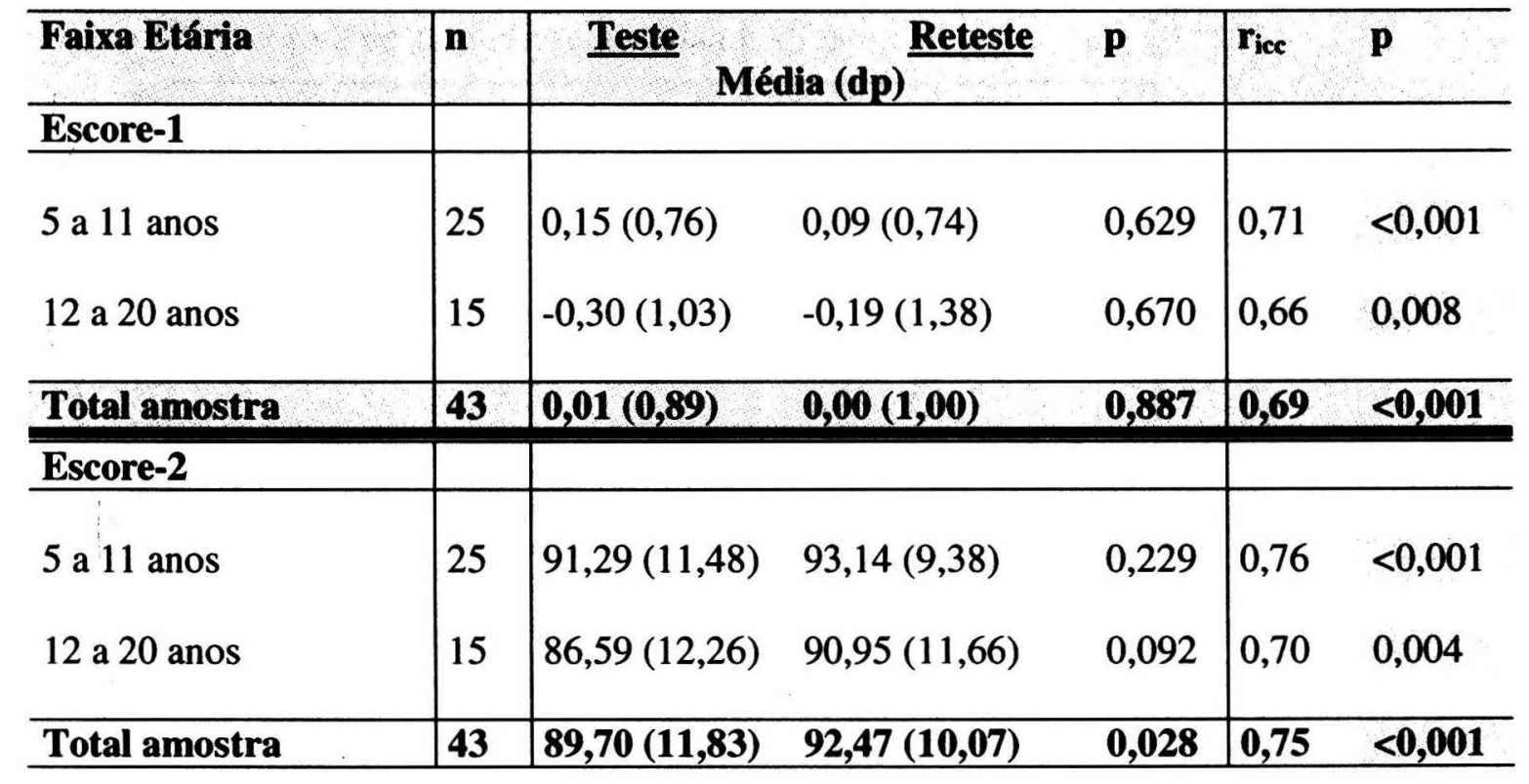


Análise da reprodutibilidade dos escores 1 e 2 de auto-eficácia pelo gráfico de Bland Altman.

Nas Figuras 36 e 37 é possível verificar que existe concordância entre os dois momentos da pesquisa tanto para o escore-1 de auto-eficácia como para o escore-2. Houve boa distribuição aleatória ao redor do zero, com poucos pontos fora do limite.

Figura 36: Escore-1 de auto-eficácia - Bland Altman.

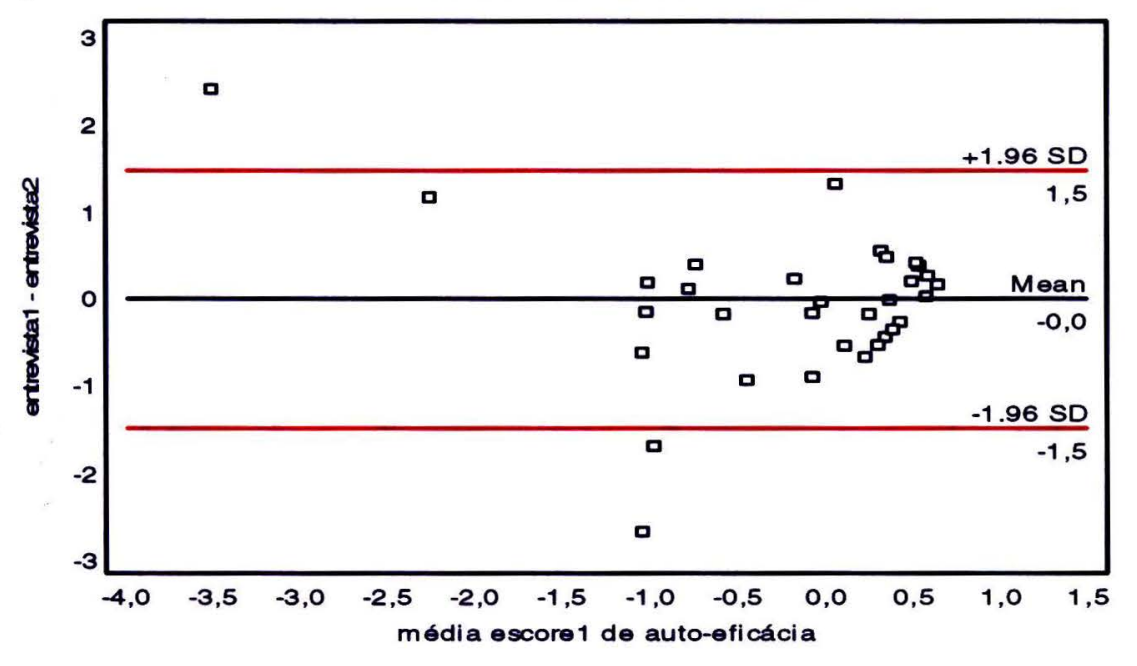

Figura 37: Escore-2 de auto-eficácia - Bland Altman.

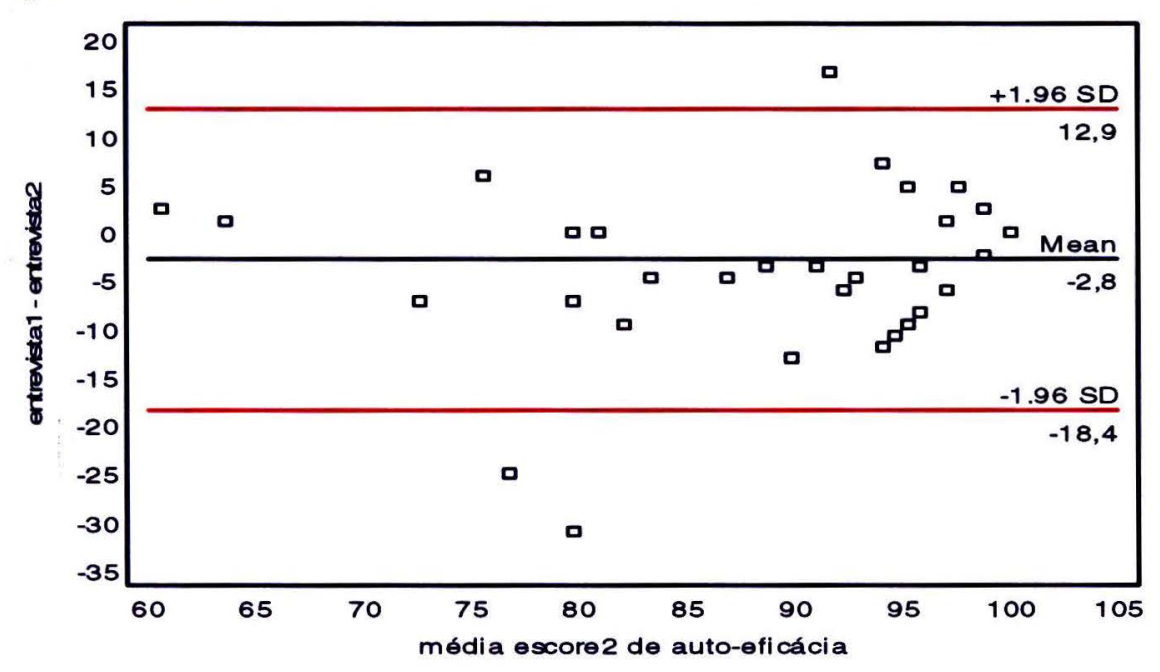




\subsection{ANÁLISE GRÁFICA ENTRE O TESTE E O RETESTE PARA A ESCALA DE AUTO-EFICÁCIA}

A Figura 36 mostra que as médias do escore-1 de auto-eficácia foram semelhantes para no teste e no reteste para as três faixas etárias estudadas. Pode-se verificar que existe uma relação linear entre os valores do escore-1 no teste e no reteste para as três faixas etárias estudadas (Figura 37).

Figura 38: Médias e respectivos intervalos de 95\% de confiança do escore-1 de autoeficácia nas duas entrevistas, segundo faixa etária.

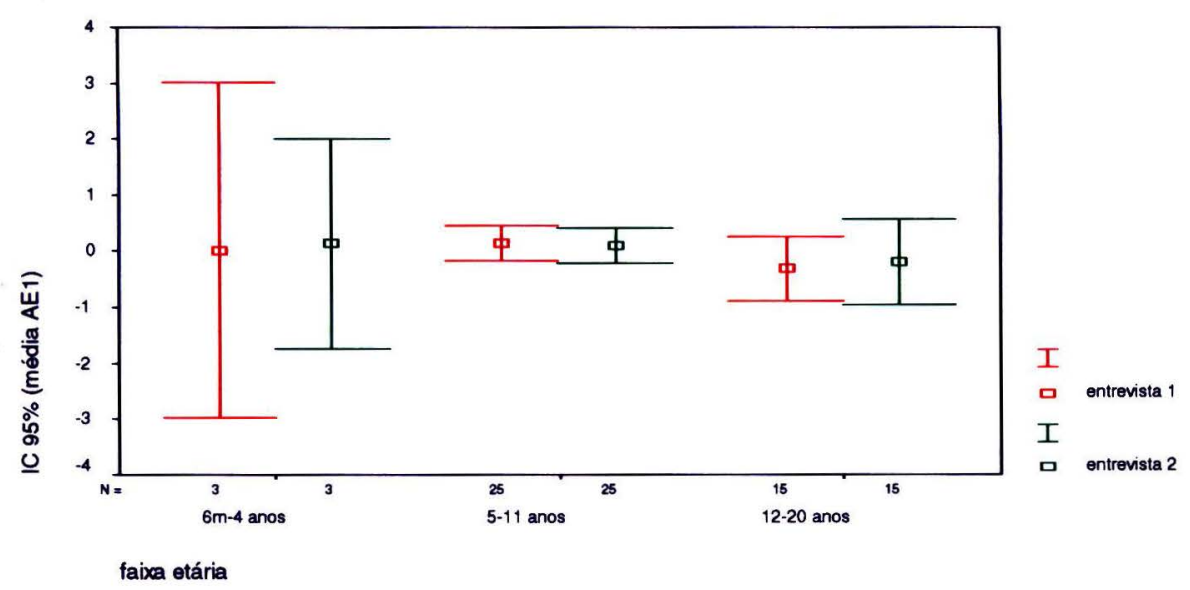

Figura 39: Diagrama de dispersão entre os valores do escore-1 de escala de auto-eficácia nas duas entrevistas, segundo faixa etária.

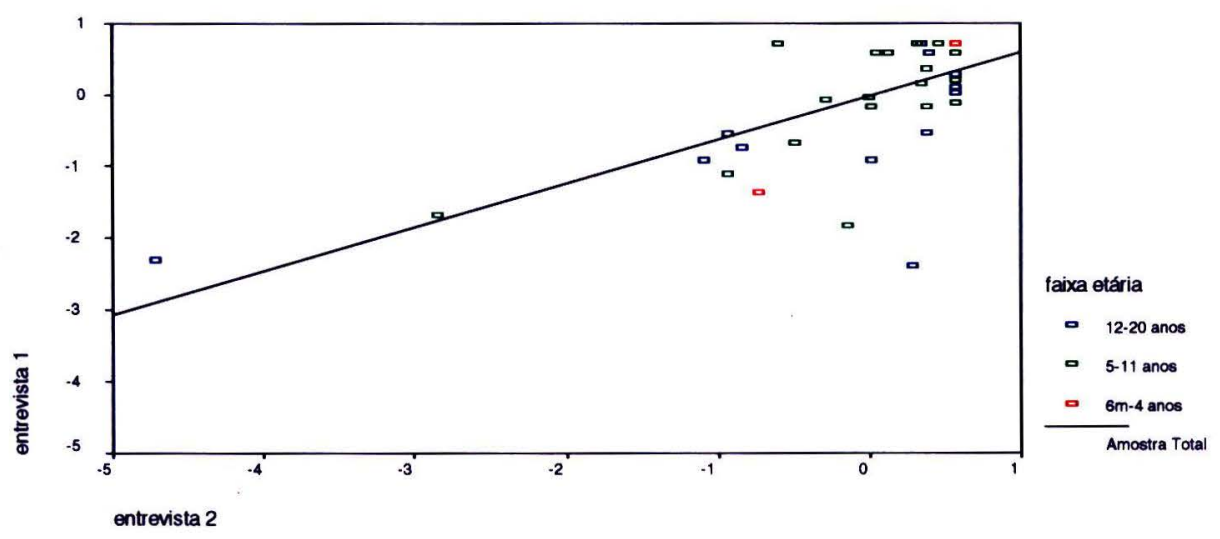


Na Figura 40 é possível observar que as médias do escore-2 de auto-eficácia foram semelhantes nos dois momentos da pesquisa, para as três faixas etárias. $O$ diagrama de dispersão da Figura 41 mostra a existência de uma relação linear entre os valores do escore- 2 no teste e no reteste, para as três faixas etárias.

Figura 40: Médias e respectivos intervalos de $95 \%$ de confiança do escore- 2 de autoeficácia nas duas entrevistas, segundo faixa etária.

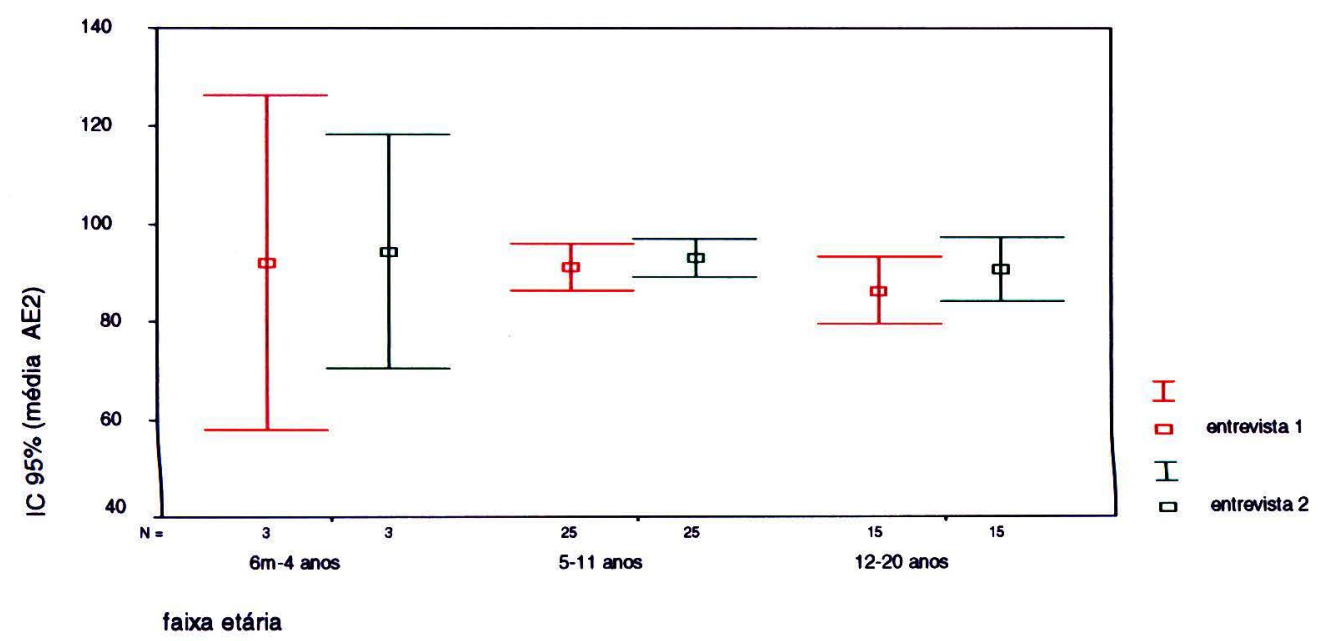

Figura 41: Diagrama de dispersão entre os valores do escore-2 de escala de auto-eficácia nas duas entrevistas, segundo faixa etária.

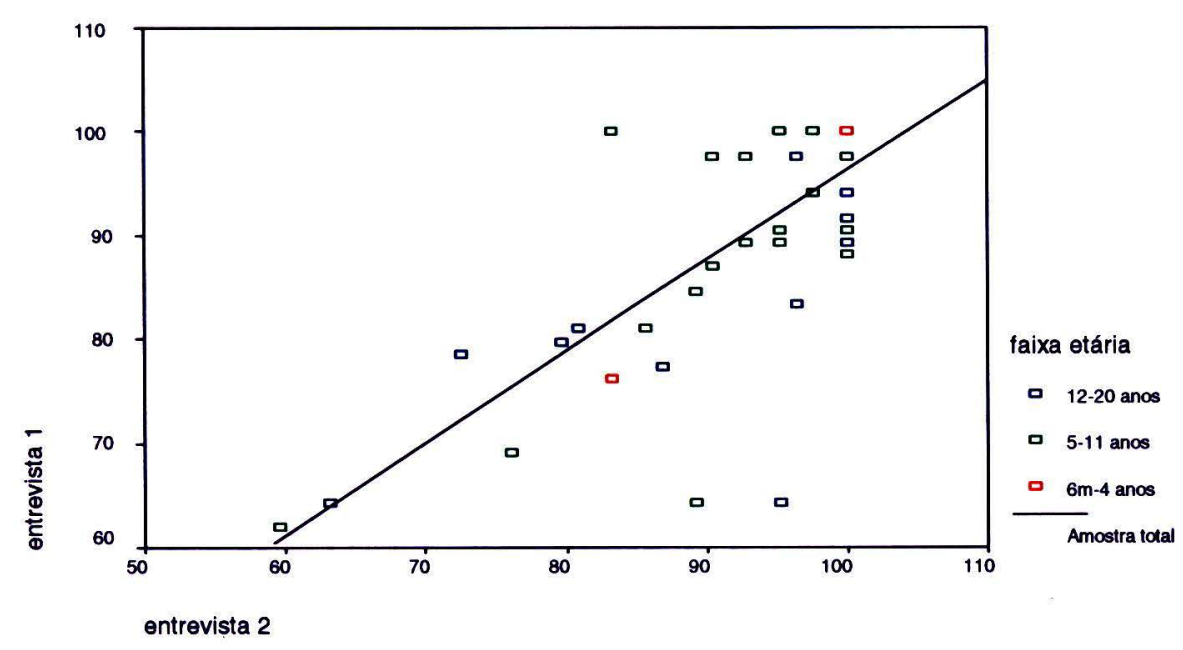




\section{DISCUSSÃO}

Este trabalho teve como objetivos traduzir, validar e verificar a reprodutibilidade do questionário de qualidade de vida relacionada à saúde "Quality Life Assessment" e validar e verificar a reprodutibilidade da escala de auto-eficácia para seguir prescrição anti-retroviral, em crianças e adolescentes com HIV/Aids. Essa pesquisa justifica-se pelo fato de que questões importantes como qualidade de vida relacionada à saúde e adesão aos medicamentos anti-retrovirais em crianças e adolescentes com HIV/Aids vêm sendo estudadas em muitos países do mundo e, no Brasil, nenhum instrumento de qualidade de vida ou de adesão foi traduzido e validado para a população de crianças e adolescentes com HIV/Aids.

\subsection{ASPECTOS METODOLÓGICOS}

Este estudo foi realizado em um Centro de Referência e Treinamento em DST/Aids da cidade de São Paulo, vinculado à Secretaria da Saúde do Estado de São Paulo, que tem como uma de suas atribuições prestar assistência integral aos pacientes matriculados no CRT-DST/Aids. O CRT-DST/Aids tem mais de 43.000 pacientes registrados em seu banco de dados; destes mais de 24.000 estão matriculados no ambulatório de Aids. Estes pacientes são provenientes de todas as regiões do Estado de São Paulo (CRT - DST/AIDS, 2001).

O Ambulatório de HIV/Aids pediátrico no CRT - DST/AIDS teve início em 1989 e está estruturado com a participação de três pediatras, uma enfermeira, uma psicóloga, uma fonoaudióloga e uma assistente social. Até o começo de 2005 passaram pelo serviço mais de 800 crianças menores de 13 anos sendo que mais de $90 \%$ delas correspondiam à categoria de exposição materno infantil (transmissão vertical) (CRT DST/AIDS, 2001).

Embora tenha sido feito um cálculo de tamanho da amostra de 25 crianças com HIV/Aids para cada faixa etária, foram convidados para participar do estudo de validade 
e reprodutibilidade de instrumentos, todos os pais/cuidadores das crianças e adolescentes que passavam no Hospital Dia do CRT/SP para uma consulta de rotina, todos os dias da semana durante os três turnos de atendimento, no período de abril a agosto de 2005. Dos 134 pacientes registrados no serviço em 2005 conseguiu-se entrevistar 90 pais/cuidadores, o que corresponde a $67,2 \%$ da população de estudo. Destaca-se que apenas na faixa etária de 12 a 20 anos não se chegou no tamanho inicial proposto.

Os adolescentes foram a categoria etária que mais apresentou problemas durante a pesquisa. Além de faltarem nas consultas, vinham, na maior parte das vezes, desacompanhados dos pais/responsáveis, o que impossibilitava a realização das entrevistas. Nos casos de adolescentes desacompanhados foi solicitado ao adolescente vir na próxima consulta acompanhado dos pais/responsáveis, o que ocorreu na maioria das vezes. Mesmo assim, foram deixados de entrevistar apenas 3 adolescentes desacompanhados e um adolescente que se recusou a participar. Mesmo assim, não se acredita que tenha havido distorções nos resultados, pois como esses pacientes estavam passando em consulta de rotina no serviço, acredita-se que a perda tenha sido aleatória.

Quando se compara a amostra de crianças deste estudo com os dados do MINISTÉRIO DA SAÚDE (2006a), verifica-se que as proporções de pacientes do sexo feminino e masculino são semelhantes. Nesta amostra tem-se $42,2 \%$ de homens e $57,8 \%$ de mulheres, enquanto que no país há $53,2 \%$ de homens e $46,8 \%$ de mulheres entre os pacientes com menos de 20 anos.

Em relação à distribuição etária, esta é diferente na amostra quando se compara com dados do MINISTÉRIO DA SAÚDE (2006a). Enquanto que nos dados nacionais de Aids os casos se concentram na faixa etária até 4 anos de idade $(47,1 \%)$, neste estudo a porcentagem nesta faixa é de $4,4 \%$. Já a faixa mais freqüente, neste estudo, foi a de 5 a 11 anos $(38,9 \%)$ que nos dados do MS correspondem a $18,0 \%$. A faixa de 12 a 20 anos, neste estudo, concentra $22,2 \%$ dos casos, enquanto que a faixa correspondente do MS tem $35,0 \%$ dos casos.

Quando se considera os dados de casos de Aids por faixa etária no Estado de São Paulo, no ano de 2005 (CRT - DST/AIDS, 2005), a porcentagem de casos em menores 
de 5 anos é de $34,0 \%$ (versus 4,0\% na amostra). A faixa etária de 5 a 14 anos tem $34,0 \%$ dos casos (versus $18,0 \%$ na amostra) e a faixa e a faixa de 15 a 19 anos tem $31,0 \%$ dos casos (versus 22,2\% na amostra).

Por tudo isso, conclui-se que a amostra tem uma distribuição etária diferente quando se compara com os dados do país e do Estado de São Paulo. Vale ponderar que os dados do país e do Estado de São Paulo são cumulativos e não retratam a realidade atual dos pacientes ativos nos serviços, sobreviventes e sob tratamento (dados estes que não se dispõe), pois incluem todos os pacientes notificados, inclusive aqueles que já morreram. No entanto, a validação e a reprodutibilidade dos instrumentos foi feita segundo faixa etária. Por isso, supõe-se que estas diferenças não prejudicaram este estudo.

A validade interna de um estudo refere-se ao grau em que as conclusões desse estudo são corretas para a amostra de indivíduos estudados (PEREIRA, 1995b). Embora este seja um estudo de validação e reprodutibilidade de instrumentos, destacam-se, nesta seção, alguns cuidados que foram tomados de modo a evitar erros sistemáticos (vieses).

A fase de planejamento da pesquisa, em que a pesquisadora elaborou uma listagem dos pacientes, seus dias e horários de atendimento e seus médicos facilitou a logística e garantiu que a aluna/entrevistadora estivesse no local da pesquisa durante os períodos de atendimento do serviço.

Para minimizar vieses de aferição foram utilizados questionários de qualidade de vida relacionada à saúde e de auto-eficácia para seguir prescrição anti-retroviral já validados em outros países, como é o caso do primeiro, ou em adultos brasileiros, como é o caso do segundo.

Uma questão que é colocada como uma limitação é o fato dos pais/cuidadores responderem pelas crianças/adolescentes. EISER e MORSE (2001) colocam que os estudos de qualidade de vida que levam em conta a perspectiva dos pais/cuidadores, nas diferentes faixas etárias, são mais fáceis de serem realizados quando comparados com aqueles que levam em conta as duas ou mais perspectivas (criança/adolescente, pais/cuidadores, médicos). As distorções entre as respostas dos pais/cuidadores e dos 
filhos podem ocorrer e elas tendem a diminuir com a idade da criança, pois com o desenvolvimento de habilidades verbais, a criança passa a descrever melhor suas experiências e emoções aos pais/cuidadores.

Para crianças acima de 5 anos, espera-se que os pais/cuidadores tenham uma maior dificuldade de relato de qualidade de vida nos domínios que envolvem comportamentos menos visíveis como emoções e atividades sociais (EISER e MORSE, 2001). Assim sendo, os domínios de avaliação psicológica e Atividades Pessoais e Sociais (5 a 20 anos) podem ter algum viés referente a esse problema. Já para os adolescentes, acima de 12 anos, os autores relatam que o julgamento dos pais sobre os sintomas da doença tende a não ser o mais preciso, pois os próprios adolescentes já têm maturidade para entender a doença e relatar sua experiência. Segundo LEE e col. (2006), os pais/cuidadores podem dar ou não uma visão precisa da qualidade de vida de suas crianças/adolescentes e isso incentiva que técnicas alternativas para coletar a informação de qualidade de vida diretamente das crianças/adolescentes devem ser desenvolvidas.

Neste estudo optou-se por colocar a visão dos pais/cuidadores, por ser esta a recomendação dos autores do questionário de qualidade de vida.

\subsubsection{Qualidade de Vida}

Neste estudo traduziu-se, validou-se e avaliou-se a reprodutibilidade do questionário de Avaliação da Qualidade de Vida (Quality of life assessment). Este é um instrumento multidimensional e que foi construído baseado nas experiências de outros estudos para compor os domínios que constituem o questionário. $\mathrm{O}$ estudo original de validação do questionário foi realizado por GORTMAKER e col. (1998) onde foram estudadas 444 crianças/adolescentes de 5 a 11 anos, sendo que 190 delas tinham o diagnóstico de Aids.

Este estudo foi o primeiro no Brasil a fazer a tradução e a validação do questionário de qualidade de vida para as crianças e adolescentes com HIV/Aids. $O$ modelo usado para a adaptação transcultural foi aquele proposto por HERDMAN e col. 
(1998) é apenas um dentre outros disponíveis na literatura na área de qualidade de vida e saúde (REICHENHEIM e MORAES, 2007).

$\mathrm{Na}$ etapa de equivalência conceitual e de itens constatou-se que os itens são pertinentes ao contexto cultural brasileiro. Procurou-se modificar o mínimo possível a estrutura do questionário e, apesar de algumas modificações/inclusões de itens/questões, acredita-se que as alterações não prejudiquem a comparabilidade com o instrumento original.

No final do processo de avaliação semântica obteve-se uma primeira versão em português do instrumento de qualidade de vida. A adaptação do questionário para o português não apresentou problemas e todas as adaptações foram devidamente incorporadas na versão final em português. Entretanto, há que se considerar que o questionário pode conter termos que são perfeitamente entendíveis na região sudeste do país, mas podem não ser, por exemplo, nas regiões norte e nordeste. Assim, se forem feitas pesquisas considerando este instrumento em outras regiões do país, ajustes regionais podem ser requeridos.

O resultado positivo das etapas de avaliação da equivalência conceitual e de itens e também da equivalência semântica pode ser justificado pela excelente aceitabilidade do instrumento durante o trabalho de campo. Porém, vale colocar aqui que a aplicação do instrumento foi um tanto quanto cansativa devido ao grande número de itens/questões e o instrumento levou em torno de 20 minutos para ser aplicado. Assim, é interessante recomendar uma redução do número de itens para que uma versão mais breve do instrumento possa ser utilizada. Uma opção a ser adotada poderia ser a escolha das questões que foram confirmadas na análise fatorial realizada neste estudo.

Há um consenso na literatura sobre a questão do questionário de qualidade de vida ser auto-respondido, para se levar em conta a percepção individual. Entretanto este aspecto mostrou-se um pouco fora da realidade nesta pesquisa, pois o questionário foi lido e administrado pela aluna/pesquisadora na maior parte das vezes $(78,9 \%$ dos participantes) por conta do respondente não ter condições de ler e preencher o questionário sozinho, devido à sua saúde ou alfabetização. Esta situação não foi a ideal, 
pois, segundo MORAES e col. (2002), a forma de entrevistas pode subestimar a ocorrência de eventos, principalmente em questões que são constrangedoras. Entretanto, uma vez que o questionário de qualidade de vida não contém situações desse tipo, acredita-se que esse viés não tenha ocorrido.

Destaca-se que há versões específicas para as 3 faixas etárias, a saber: 6 meses a 4 anos, 5 a 11 anos e 12 a 20 anos que consideram as diversas fases de desenvolvimento das crianças. A qualidade de vida ficaria comprometida se um único questionário for utilizado para todas as idades, da infância até a adolescência, uma vez que desenvolvimento está sofrendo mudanças de acordo com a idade (GORTMAKER e col. 1998, EISER e MORSE, 2001).

\subsubsection{Faixa etária de 6 meses a 4 anos}

\section{Equivalência de mensuração}

A consistência interna para o domínio de Avaliação Geral da Saúde obtida neste estudo foi de 0,41 para a faixa etária de 6 meses a 4 anos. No estudo de origem do questionário, a consistência foi de 0,86 (Gortmaker e col., apud LEE e col., 2006). Fica evidente que a consistência interna deste estudo é mais baixa do que a obtida no estudo original de validação do questionário.

As questões do domínio de Avaliação Geral da Saúde referem-se à percepção dos pais/cuidadores sobre a saúde de uma maneira geral, fisicamente e emocionalmente. Como as crianças dessa faixa eram ainda bebês pode ser que os pais/cuidadores tenham sentido uma dificuldade para fazer a ligação destes três aspectos. $O$ fato de que os bebês choram muito pode ter contribuído para que a questão sobre o emocional tenha obtido pontuações mais baixas que as demais. Por outro lado, do ponto de vista estatístico, a baixa consistência interna obtida na faixa etária de 6 meses a 4 anos pode ter ocorrido devido às fracas correlações entre as questões. Entretanto, para esse domínio, havia somente 3 questões e quanto menor o número de questões aumenta-se a probabilidade de 
haver pior consistência. STREINER (2003) explica que o $\alpha$ é fortemente afetado pelo tamanho da escala e que quanto maior a correlação entre os itens, maior será o $\alpha$ de Cronbach. A ampliação do número de questões neste domínio talvez mereça ser levada em conta em uma revisão futura.

O domínio de Resistência Física é uma parte do domínio de Avaliação Geral da Saúde e existe nos questionários das faixas etárias de 6 meses a 4 anos e 5 a 11 anos. A consistência interna obtida neste estudo foi de 0,10 para a faixa etária de 6 meses a 4 anos, enquanto que no estudo Gortmaker e col., apud LEE e col. (2006), ela foi 0,59 para a faixa em questão. Conclui-se que a consistência interna para a Resistência Física não foi boa e mostrou-se inferior àquela encontrada no estudo de Gortmaker e col., apud LEE e col. (2006). Por outro lado, nota-se que a falta de homogeneidade entre os itens deste domínio não é particularidade deste estudo, pois no estudo original de validação do questionário, a consistência interna também não foi boa. As questões deste domínio envolvem aspectos positivos e negativos sobre a saúde das crianças e pode ter ocorrido dos pais/responsáveis valorizarem demais o aspecto positivo em detrimento do negativo ou vice-versa.

Este domínio talvez devesse ser revisto no sentido de reduzir as questões que o compõem uma vez que a correlação entre elas não foi boa. Em que pese o fato de que se houver redução no número de questões deste domínio, perde-se a comparabilidade do questionário com o questionário original, sugere-se esta revisão. Do total de 7 questões, apenas 4 foram confirmadas na análise fatorial.

Neste estudo, a consistência interna para a Avaliação do Estado Físico foi 0,30 para a faixa etária de 6 meses a 4 anos, porém no estudo de Gortmaker e col., apud LEE e col. (2006) o resultado da consistência interna para este domínio nesta faixa etária não é apresentado. Embora não se tenha como comparar o resultado do $\alpha$ com o estudo original, nota-se também neste domínio uma falta de homogeneidade entre as questões e pode-se sugerir uma revisão das questões que compõem este domínio, afim de se melhorar a sua consistência interna. 
Para o domínio de Avaliação das Atividades Pessoais e Sociais foi calculado o $\alpha$ de Cronbach, mas este mostrou-se negativo. STREINER (2003) coloca que há basicamente duas causas para o valor de $\alpha$ ser negativo. A primeira delas, e a mais fácil de ser remediada, decorre de correlação negativa entre os itens ou questões do domínio e neste caso, os escores do itens devem ser revertidos. A segunda diz respeito a um problema na construção original do domínio, pois neste caso as variabilidades individuais dos itens excedem a variância compartilhada, o que pode ocorrer quando os itens estão representando diferentes constructos.

O domínio das Atividades Pessoais e Sociais é composto realmente de duas partes, sendo que as respostas da parte A são escores de um a seis, e as da parte B são respostas do tipo sim e são. Acredita-se que o $\alpha$ negativo encontrado neste domínio seja por conta das diferenças entre os itens deste domínio, pois no estudo original de validação, a consistência interna também não foi boa e os autores justificam dizendo que o $a$ não é confiável para o domínio por conta da estrutura deste.

A consistência interna obtida para o domínio de Utilização dos Serviços de Saúde foi de 0,50 para a faixa etária de 6 meses a 4 anos. No estudo de GORTMAKER e col. (1998) a consistência interna para esse domínio não foi calculada, pois os autores colocam que ele serve como apoio para fazer comparações com os outros domínios de qualidade de vida. Vale a pena colocar que a estrutura deste domínio também abrange questões com dois tipos de respostas (escores e sim/não) e o $\alpha$ obtido aponta a falta de homogeneidade entre os itens, o que é concebível se considerarmos que os itens expressam diferentes tipos de constructos que embora sejam relacionados à Utilização dos Serviços de Saúde um deles diz respeito às hospitalizações, visitas ao médico e o outro diz respeito ao uso de medicações.

Neste estudo, o domínio de Sintomas ou Sinais apresentou consistência interna de 0,78 para a faixa etária de 6 meses a 4 anos, enquanto que no estudo de Gortmaker e col., apud LEE e col. (2006) a consistência interna foi de 0,80 para esta faixa etária. Conclui-se que este domínio foi o que obteve a melhor consistência interna na faixa 
etária de 6 meses a 4 anos e o seu valor foi próximo ao encontrado no estudo original de validação.

Em resumo, o questionário de qualidade de vida para a faixa etária de 6 meses a 4 anos necessita de uma revisão das questões que compõem quase todos os domínios, com exceção do domínio de Sintomas ou Sinais.

A análise fatorial clássica utiliza o estimador de máxima verossimilhança para estimativas dos parâmetros. Entretanto, uma suposição básica para que o modelo seja usado é de que as variáveis ou questões sejam contínuas e sigam uma distribuição Normal. SHARMA (1996) coloca que quando os dados não seguem uma distribuição Normal, alguns métodos alternativos como quadrados mínimos generalizados, técnicas elípticas e métodos de distribuições livres para se estimar parâmetros podem ser utilizados.

JÖRESKOG e MOUSTAKI (2006) colocam que as variáveis ou questões de uma escala nem sempre atendem à suposição de normalidade, pois são variáveis ordinais $\mathrm{e}$ estão representadas por categorias. Para lidar com isto os autores propõem um modelo de análise fatorial para variáveis ordinais que baseia-se no método da informação cheia da máxima verossimilhança (Full Information Maximum Likelihood - FIML) que estima parâmetros em função da distribuição do padrão de respostas para as questões. $O$ método trabalha com duas aproximações para a função resposta: uma baseada na "função resposta da ogiva normal" e a outra na "função resposta logística" para estimativa de parâmetros do modelo fatorial.

Para a faixa etária de 6 meses a 4 anos fez-se a análise fatorial confirmatória utilizando o método proposto por JÖRESKOG e MOUSTAKI (2006) e utilizou-se as duas funções resposta para estimativa de parâmetros. Alguns testes foram feitos e não foram verificadas diferenças entre as duas aproximações. Optou-se por trabalhar com a "função resposta logística".

$\mathrm{O}$ modelo fatorial utilizado possibilitou trabalhar com variáveis qualitativas e apresentou solução mesmo para amostra de $n=35$, no caso para a faixa de 6 meses a 4 
anos. E ainda, permitiu identificar, dentro de cada domínio, quais seriam as questões realmente relevantes (\% variâncias maiores, cargas altas).

$\mathrm{Na}$ análise fatorial para a faixa etária de 6 meses a 4 anos alguns aspectos merecem ser destacados. A estrutura do questionário foi mantida com todos os domínios já estabelecidos a priori.

No domínio de Avaliação Geral da Saúde, o número de questões se manteve, porém duas delas mostraram-se mais importantes para o domínio. A questão "emocionalmente" apresentou uma carga fatorial baixa e não contribuiu muito para o fator. Vale considerar que esta questão recebeu pontuações ou notas baixas, dadas pelos responsáveis pelas crianças, no questionário de qualidade de vida, fator este que prejudicou a consistência interna do domínio das Atividades Pessoais e Sociais.

Nos demais domínios do questionário de qualidade de vida o número de questões não se manteve e as questões selecionadas para estes domínios foram as que realmente mostraram-se relevantes para sua composição. A proposta de um instrumento reduzido, considerando os itens/questões selecionados na análise fatorial deve ser estudada e debatida tendo em vista a melhora das propriedades psicométricas do instrumento e também a facilidade para aplicação do mesmo.

Discutindo agora a validade de constructo, a comparação de médias entre grupos baseou-se nos grupos de pacientes definidos de acordo com o estágio da doença nos estudos em adultos com HIV/Aids (WU e col, 1991; DE BOER e col., 1995; REVICKI e col., 1995; LEE e col. 2006) e também no estudo de validação deste instrumento em crianças (GORTMAKER e col., 1998). Alguns estudos comparam pacientes com HIV, porém assintomáticos com pacientes sintomáticos e outros comparam pacientes infectados com os não infectados pelo HIV.

O estudo realizado por WEINFURT e col. (2000) mostrou que o aumento nos escores de qualidade de vida do questionário MOS-HIV-30 ao longo do tempo esteve correlacionado com a diminuição da carga viral e com o aumento de CD4. Já no estudo de GORTMAKER e col. (1998), os escores foram correlacionados com os marcadores de Utilização dos Serviços de Saúde e não com os marcadores clínicos, pois esperam-se 
efeitos negativos nos escores de qualidade de vida quando há um aumento na sua utilização.

O questionário de qualidade de vida conseguiu discriminar o grupo de crianças expostas daquele de doentes no domínio de Estado Físico $(\mathrm{p}=0,009)$, na faixa etária de 6 meses a 4 anos. Este resultado é perfeitamente esperado uma vez que as crianças doentes apresentaram um escore menor de Estado Físico quando comparadas com as crianças expostas. Este achado é semelhante ao encontrado no estudo de LEE e col. (2006) que obteve diferença de médias no escore de Estado Físico quando comparou crianças infectadas e não infectadas nesta faixa etária. Já o estudo de GORTMAKER e col. (1998) não fez a comparação de médias na faixa etária de 6 meses a 4 anos.

Com relação aos marcadores de Utilização dos Serviços de Saúde, nesta faixa etária, não houve correlação significativa entre o número de noites passadas no hospital nas últimas 4 semanas e os escores de qualidade de vida. Este resultado está dentro do esperado, pois somente uma criança ficou internada e as demais não tiveram internação nesta faixa etária. Houve correlação negativa e significativa entre o número de visitas ao serviço e o escore de Resistência Física $(r=-0,37 ; p=0,031)$ e entre o número de visitas e o escore de Utilização dos Serviços de Saúde $(r=-0,45 ; p=0,007)$. Estes resultados fazem sentido do ponto de vista teórico, pois no que concerne à Resistência Física, as crianças menos doentes, menos suscetíveis às doenças, enfim, com uma saúde melhor são as que menos freqüentam o serviço de saúde. Espera-se também um aumento do escore de Utilização dos Serviços de Saúde (menos procura) quando há uma diminuição no número de visitas ao serviço. No estudo de GORTMAKER e col. (1998) não foi feita a análise de correlação entre os escores de qualidade de vida e os marcadores de Utilização dos Serviços de Saúde nesta faixa etária.

Os resultados sobre reprodutibilidade são inéditos para este questionário de qualidade de vida uma vez que, no estudo original de validação do mesmo, a análise da reprodutibilidade não foi feita e é apontada como uma limitação do mesmo (GORTMAKER e col., 1998). 
Na comparação de médias dos escores de qualidade de vida entre os teste e o reteste, obteve-se igualdade médias em todos os domínios do questionário de qualidade de vida para a faixa etária de 6 meses a 4 anos.

$\mathrm{Na}$ análise do coeficiente de correlação intraclasse $\left(r_{i c c}\right)$ entre o teste e o reteste verifica-se que ele foi significativo e acima de 0,70 nos domínios de Resistência Física, Estado Físico e Sintomas ou Sinais. No domínio de Avaliação Geral da Saúde o $r_{\text {icc }}$ foi de 0,44 e significativo. Nos domínios das Atividades Pessoais e Sociais e Utilização dos Serviços de Saúde o $r_{i c c}$ não foi significativo. $O$ cálculo do $r_{i c c}$ para os domínios das Atividades Pessoais e Sociais e Utilização dos Serviços de Saúde certamente foi prejudicado pelo pequeno número de observações que tiveram escores diferentes entre o teste e o reteste (pouca variabilidade dos escores), uma vez que a grande parte das crianças apresentou escores idênticos ou semelhantes nas duas entrevistas.

Os gráficos de Bland-Altman mostraram uma boa concordância entre o teste e o reteste para os escores de qualidade de vida, na faixa etária de 6 meses a 4 anos. Pode-se concluir que o questionário de qualidade de vida se manteve estável entre as duas entrevistas mostrando, com isso, uma boa reprodutibilidade.

\subsubsection{Faixa etária de 5 a 11 anos}

\section{Equivalência de mensuração}

A consistência interna para o domínio de Avaliação Geral da Saúde foi de 0,76 para a faixa etária de 5 a 11 anos sendo este resultado semelhante àquele encontrado no estudo de GORTMAKER e col. (1998), que obteve um $\alpha$ de 0,86 .

No domínio de Resistência Física, que é parte da Avaliação Geral da Saúde, a consistência interna obtida para a faixa etária em questão foi de 0,13 . Esta consistência interna não foi boa e mostrou-se inferior àquela obtida no estudo original de validação do questionário de qualidade de vida, que foi de 0,70 (GORTMAKER e col.,1998). 
A baixa consistência interna obtida neste domínio está refletindo a falta de homogeneidade entre as questões deste domínio. Vale colocar que uma revisão das questões deste domínio merece ser considerada.

Neste estudo a consistência interna para a Avaliação do Estado Físico foi 0,90 para a faixa de 5 a a11 anos, enquanto que no estudo de GORTMAKER e col. (1998) ela foi de 0,97 . Pode-se concluir que neste estudo a consistência interna obtida para a faixa de 5 a 11 anos foi semelhantes àquele obtida no estudo original.

Para o domínio de Avaliação da Saúde Psicológica, a consistência interna foi de 0,78 para a faixa etária de 5 a 11 anos, enquanto que o estudo de GORTMAKER e col. (1998) obteve consistência interna de 0,91 nesta mesma faixa. Embora a consistência interna tenha sido inferior àquela encontrada no estudo original, pode-se concluir que ela foi boa para o domínio de Avaliação da Saúde Psicológica.

Para o domínio de Avaliação das Atividades Pessoais e Sociais foi calculado o $\alpha$ de Cronbach, mas este mostrou-se negativo. Atribui-se este valor negativo do $\alpha$ a falta de homogeneidade entre os itens que estão representando dois subdomínios (partes $\mathrm{A} \mathrm{e}$ B) deste domínio, com estruturas diferentes. No estudo original de validação os autores se apóiam na diferença de estrutura deste domínio para justificar a falta de consistência interna.

A consistência interna obtida para o domínio de Utilização dos Serviços de Saúde foi de 0,44 para a faixa de 5 a 11 anos. No estudo de GORTMAKER e col. (1998) a consistência interna para esse domínio não foi calculada, pois os autores colocam que ele serve como apoio para fazer comparações com os outros domínios de qualidade de vida.

A baixa consistência interna obtida para este domínio também pode ser atribuída à própria composição do domínio, que como o de Avaliação das Atividades Pessoais e Sociais é estruturado em duas partes.

Neste estudo, o domínio de Sintomas ou Sinais apresentou consistência interna de 0,85 para a faixa etária de 5 a 11 anos, enquanto que no estudo de GORTMAKER e col. (1998) a consistência interna foi de 0,84 para esta faixa etária. Conclui-se que este 
domínio foi o que obteve melhor consistência interna nesta faixa etária e seu valor é praticamente idêntico ao do estudo americano.

Em resumo, o questionário de qualidade de vida para a faixa etária de 5 a 11 anos apresentou consistência interna acima de 0,70 na maioria dos domínios, Avaliação Geral da Saúde, Saúde Psicológica, Estado Físico e Sinais e Sintomas.

A análise fatorial confirmatória para a faixa etária de 5 a 11 anos foi feita utilizando o método proposto por JÖRESKOG e MOUSTAKI (2006) e trabalhou-se com a "função resposta logística" para estimativa de parâmetros.

Diante dos resultados da análise fatorial pode-se concluir que a estrutura do questionário se manteve em relação a praticamente todos os domínios. Alguns pontos desta análise devem ser destacados. Para o domínio de Avaliação Geral da Saúde, não foi possível obter uma solução fatorial. Este fato aconteceu, pois a análise fatorial ordinal trabalha com padrões semelhantes de respostas para as questões ou itens e na faixa de 5 a 11 anos não foi possível obter um padrão semelhante nas respostas para as quatro questões que compõem este domínio e desta forma não se conseguiu fazer a estimativa dos parâmetro do modelo fatorial.

Para os demais domínios, todas as questões selecionadas para compor o fator tiveram cargas fatoriais altas, o que permitiu que os fatores explicassem mais de $80 \%$ da variância total dos dados para os domínios de Avaliação do Estado Físico, Avaliação das Atividades Pessoais e Sociais e Sinais ou Sintomas. Para os domínios de Resistência Física, Avaliação da Saúde Psicológica e Utilização dos Serviços de Saúde as cargas fatoriais também foram altas e os fatores explicaram aproximadamente $40 \%$ da variância total dos dados.

Os resultados da análise fatorial podem servir de apoio para a melhoria do questionário de qualidade de vida na faixa etária de 5 a 11 anos, principalmente nos domínios de Resistência Física e Utilização dos Serviços de Saúde que tiveram as consistências internas mais baixas $(\alpha<0,70)$ quando comparadas com os demais domínios. 
Discutindo agora a validade de constructo, os escores de qualidade de vida discriminaram crianças assintomáticas e com sinais/sintomas leves daquelas com sinais/sintomas moderados, nos seguintes domínios: Avaliação Geral da Saúde, Estado Físico e Sintomas ou Sinais. Esses resultados são esperados, pois as crianças com as piores categorias clínicas do CDC devem apresentar os piores escores de qualidade de vida quando comparadas com aquelas que têm as melhores categorias. No estudo de GORTMAKER e col. (1998), que analisou a faixa etária de 5 a 11 anos, obteve-se diferença entre os grupos de crianças infectadas e não infectadas, nos domínios de Avaliação Geral da Saúde, Resistência Física, Atividades Pessoais e Sociais e Sintomas ou Sinais. Já LEE e col. (2006) observaram diferenças das médias dos escores dos domínios de Avaliação Geral da Saúde, Resistência Física, Estado Físico, Avaliação Psicológica, e Atividades Pessoais e Sociais na comparação entre os grupos de crianças infectadas e não infectadas.

Pode-se perceber que tanto no estudo de GORTMAKER e col. (1998) quanto no de LEE e col. (2006) não foram obtidas diferenças de médias dos escores de qualidade de vida em todos os domínios do questionário, na faixa etária de 5 a 11 anos, quando se fez a comparação entre grupos, mesmo trabalhando com crianças infectadas e nãoinfectadas pelo HIV. De certa forma, os resultados das diferenças de médias obtidas nos domínios desta faixa etária estão coerentes com aqueles obtidos nestes estudos.

Ainda com relação à validade de constructo, na faixa etária de 5 a 11 anos não foram obtidas correlações estatisticamente significativas entre os marcadores clínicos CD4 e carga viral - e os escores de qualidade de vida. As correlações com o CD4 foram menores que 0,25 e as maiores correlações obtidas (em torno de 0,30 ) foram negativas (carga viral e o escore das Atividades Pessoais e Sociais e entre carga viral e o escore de Utilização dos Serviços de Saúde). No estudo de GORTMAKER e col. (1998) não foi feita a correlação entre os escores de qualidade de vida e os marcadores clínicos.

Desta forma, pode-se concluir que não houve correlação significativa entre os escores de qualidade de vida e os marcadores clínicos na faixa etária de 5 a 11 anos. Embora fossem esperadas correlações significativas com, por exemplo, o CD4, em 
estudos prévios com pacientes adultos com HIV/Aids, como o de LENDERKING e col. (1997), também não houve correlação significativa entre escores de qualidade de vida e CD4. Os autores explicam que a ausência de correlação pode ser decorrente do fato de que mesmo com um CD4 baixo, os pacientes podem não estar com os sintomas mais avançados da doença e, assim, o valor do CD4 pode não interferir nos escores de qualidade de vida. Uma forma mais efetiva de verificar esse tipo de relação seria por meio de estudos de coorte. Neste tipo de estudo seria possível verificar mudanças de CD4 ao longo do tempo e sua possível relação com a qualidade de vida (DE BOER e col., 1995). Entretanto acredita-se que as correlações não significativas com os marcadores clínicos não foram obtidas por conta de outro fator importante a ser comentado, que é o tamanho da amostra. Para se obter correlações em torno de 0,50 seriam necessárias, no mínimo, 29 pessoas nesse grupo ( $\alpha=0,05$ e $\beta=0,20)$, o que não ocorreu, pois a análise deste grupo de crianças foi realizada com 23 crianças que tinham carga viral $>400$ cópias.

Em relação aos marcadores de Utilização dos Serviços de Saúde, não houve correlação estatisticamente significativa entre o número de noites passadas no hospital nas últimas 4 semanas e os escores do questionário de qualidade de vida, e os coeficientes de correlação variaram de $-0,04$ a $-0,29$. Deve-se considerar que somente uma criança esteve internada enquanto que as outras não ficaram nenhum dia no hospital. Já na análise com o número de visitas ao médico nas 4 últimas semanas, houve correlação negativa e estatisticamente significativa com o escore de Utilização dos Serviços de Saúde ( $r=-0,39 ; p=0,022)$ e as correlações variaram de $-0,04$ a $-0,39$ nos domínios do questionário. No estudo de GORTMAKER e col. (1998), para o número de noites no hospital, os coeficientes de correlação variaram de $-0,05$ a $-0,37$ entre os domínios do questionário, porém os valores de $\mathrm{p}$ não foram disponibilizados. Na análise com o número de visitas ao médico, os coeficientes de correlação variaram de $-0,11$ a 0,34 entre os domínios, porém seus valores de $\mathrm{p}$ também não foram disponibilizados.

Pode-se concluir que na faixa etária de 5 a 11 anos não se obteve correlações significativas do ponto de vista estatístico entre os escores dos domínios do questionário 
de qualidade de vida e o número de noites passadas no hospital, nas últimas 4 semanas. Por outro lado, deve-se considerar que $97,1 \%$ das crianças nesta faixa etária não esteve internada no período referente às 4 últimas semanas, o que certamente influenciou os resultados das correlações. Na análise da correlação dos escores dos domínios e o número de visitas ao médico nas 4 últimas semanas, obteve-se correlação significativa entre o domínio de Utilização dos Serviços de Saúde e o número de visitas. Estes resultados foram semelhantes àqueles obtidos no estudo original de validação.

Como já observado, os resultados sobre a reprodutibilidade deste questionário são inéditos.

Na faixa etária de 5 a 11 anos os resultados da comparação de médias entre o teste e o reteste mostraram que na maioria dos domínios obteve-se igualdades de médias, com exceção dos domínios de Avaliação do Estado Físico $(\mathrm{p}=0,008)$ e Sintomas ou Sinais $(\mathrm{p}=0,032)$. Uma possível explicação para estas diferenças é que na primeira entrevista, das 35 crianças analisadas, três crianças tiveram escores de Estado Físico em torno de $58 \%$ enquanto que na segunda entrevista os escores foram superiores a $95 \%$. Em relação às diferenças encontradas no domínio de Sintomas ou Sinais, três crianças também apresentaram escores em torno de $60 \%, 70 \%$ na primeira entrevista e na segunda os escores foram superiores a $85 \%$. As entrevistas tiveram um intervalo, em média, de 30 a 45 dias e pode-se supor que neste intervalo algumas crianças/adolescentes possam ter sofrido mudanças na sua situação de saúde, que de certa forma refletiu nestes domínios. Uma possível forma de se evitar estas diferenças seria diminuir o intervalo entre as duas entrevistas (20 a 30 dias).

$\mathrm{Na}$ análise do coeficiente de correlação intraclasse $\left(r_{i c c}\right)$ entre os teste e o reteste verifica-se que nos domínios de Avaliação Geral da Saúde, Avaliação da Saúde Psicológica e Sintomas ou Sinais eles foram significativos entre 0,50 e 0,70. Nos domínios de Resistência Física e Estado Físico eles foram significativos, com valores de 0,48 e 0,41 , respectivamente. Por outro lado não se obteve $r_{\text {icc }}$ estatisticamente significativos nos domínios de Utilização dos Serviços de Saúde e Atividades Pessoais e Sociais $\left(r_{\text {icc }}=0,36\right.$, no limite da significância estatística). 
Os gráficos de Bland-Altman mostraram uma boa concordância entre o teste $\mathbf{e} o$ reteste para a maioria dos escores dos domínios de qualidade de vida, na faixa etária de 5 a 11 anos. Pode-se concluir que, na faixa de 5 a 11 anos, o questionário de qualidade de vida se manteve estável entre as duas entrevistas mostrando com isso uma boa reprodutibilidade.

\subsubsection{Faixa etária de 12 a 20 anos}

\section{Equivalência de mensuração}

A consistência interna para a faixa etária de 12 a 20 anos foi de 0,85 enquanto que no estudo de Gortmaker e col., apud LEE e col. (2006) a consistência interna da Avaliação Geral da Saúde foi de 0,86 nesta faixa etária. Conclui-se que a consistência interna para a Avaliação Geral da Saúde é praticamente idêntica àquela do estudo original para a faixa etária em questão.

Neste estudo a consistência interna para a Avaliação do Estado Físico foi 0,93 para a faixa etária de 12 a 20 anos, enquanto que no estudo de Gortmaker e col., apud LEE e col. (2006) o a foi de 0,96 . Pode-se concluir que a consistência interna obtida para a faixa de 12 a 20 é muito semelhante àquela obtida no estudo original.

Para o domínio de Avaliação da Saúde Psicológica, a consistência interna foi de 0,83 para a faixa de 12 a 20 anos, enquanto que no estudo de Gortmaker e col., apud LEE e col. (2006) ela foi de 0,93 para esta faixa etária. Conclui-se que a consistência interna para a faixa etária de 12 a 20 anos tem um valor um pouco mais baixo, porém é muito semelhante à do estudo original.

Para o domínio de Avaliação das Atividades Pessoais e Sociais o $\alpha$ de Cronbach foi negativo e este resultado também pode ser atribuído à questão da estrutura deste domínio, conforme já mencionado anteriormente.

A consistência interna obtida para o domínio de Utilização dos Serviços de Saúde foi de 0,47 para a faixa de 12 a 20 anos. No estudo de GORTMAKER e col. 
(1998) a consistência interna para esse domínio não foi calculada, pois os autores colocam que ele serve como apoio para fazer comparações com os outros domínios de qualidade de vida.

O resultado de uma consistência interna não muito boa neste domínio aconteceu nas três faixas etárias estudadas e também pode ser entendido à luz da estrutura do domínio que não permite homogeneidade entre as questões.

Pode-se concluir que com exceção dos domínios denominados de "apoio" Avaliação das Atividades Pessoais e Sociais e Utilização dos Serviços de Saúde - todos os outros apresentaram boas consistências internas.

Neste estudo, o domínio de Sintomas ou Sinais apresentou consistência interna de 0,82 para a faixa etária de 12 a 20 anos, enquanto que no estudo de Gortmaker e col., apud LEE e col. (2006) a consistência interna foi de 0,88. Assim, pode-se concluir que os resultados da consistência entre os dois estudos são muito semelhantes.

A análise fatorial confirmatória para a faixa etária de 12 a 20 anos foi feita utilizando o método proposto por JÖRESKOG e MOUSTAKI (2006) e trabalhou-se com a "função resposta logística" para estimativa de parâmetros.

Na faixa etária de 12 a 20 anos, a análise fatorial confirmatória apresentou solução fatorial para todos os domínios do questionário de qualidade de vida, preservando assim sua estrutura original. Como resultado da análise obteve-se um único fator para todos os domínios do questionário de qualidade de vida.

As questões selecionadas para compor o fator apresentaram cargas fatoriais altas, mostrando sua importante contribuição para o fator. Nos domínios de Avaliação Geral da Saúde, Avaliação do Estado Físico e Sinais e Sintomas o fator explicou mais de $70 \%$ da variância total dos dados, enquanto que os domínios de Avaliação da Saúde Psicológica, Avaliação das Atividades Pessoais e Sociais e Utilização dos Serviços de Saúde tiveram em torno de 50 a $60 \%$ da variância total dos dados explicada pelo fator.

Conclui-se que análise fatorial confirmatária pode servir de base para futuras modificações no questionário de qualidade de vida para a faixa etária de 12 a 20 anos. 
O questionário de qualidade de vida conseguiu discriminar grupos de pacientes no domínio de Sintomas ou Sinais (p=0,007), para a faixa etária de 12 a 20 anos. Nos demais domínios não se conseguiu discriminar entre os grupos de pacientes doentes e não doentes, possivelmente, por conta da ausência de um grupo de comparação somente com adolescentes assintomáticos. Tanto no estudo de GORTMAKER e col. (1998) como no de LEE e col. (2006) a comparação dos escores de qualidade de vida entre grupos de pacientes não foi realizada para essa faixa etária.

Considerando agora os marcadores clínicos, na faixa etária de 12 a 20 anos, não houve correlação estatisticamente significativa entre o CD4 e os escores dos domínios de qualidade de vida e os coeficientes de correlação variaram de 0,09 a 0,39. Já em relação à carga viral, obteve-se um coeficiente de correlação negativo e estatisticamente significativo entre a carga viral e o escore de Sintomas ou Sinais $(r=-0,71 ; p=0,006)$, nos demais domínios, as correlações foram negativas e variaram de $-0,29$ a $-0,39$. No estudo de GORTMAKER e col. (1998) não foi feita a análise da correlação entre os escores de qualidade de vida e os marcadores clínicos.

Embora também fossem esperadas correlações significativas com o marcador clínico CD4 na faixa etária de 12 a 20 anos, as correlações foram baixas e não significativas. Já em relação à carga viral, a análise foi feita com 13 pacientes, pois 7 deles tinham a carga viral indetectável e obteve-se uma correlação de 0,71 no domínio de Sintomas ou Sinais. Novamente, como aconteceu na faixa de 5 a 11 anos, o tamanho da amostra pode estar interferindo para se obter estas correlações significativas tanto com o CD4 quanto com a carga viral. Para se obter uma correlação de pelo menos $\mathbf{0 , 5 0}$ seriam necessárias pelo menos 29 pessoas $(\alpha=0,05$ e $\beta=0,20)$ na análise, o que não ocorreu, pois havia 20 pacientes neste grupo etário.

Conclui-se que o questionário de qualidade de vida não apresentou correlações significativas com o CD4, em nenhum domínio, na faixa etária de 12 a 20 anos. Já com relação à carga viral obteve-se esta foi obtida no domínio de Sintomas ou Sinais, evidenciando que quando se tem um aumento na carga viral, há uma piora nos Sintomas ou Sinais dos adolescentes desta faixa etária. 
A faixa etária de 12 a 20 anos foi a que apresentou maior número de correlações estatisticamente significativas entre os marcadores de Utilização dos Serviços de Saúde e os escores de qualidade de vida. Com o aumento das noites passadas no hospital, nas últimas 4 semanas, há uma piora nos escores, tanto das atividades pessoais/sociais ( $\mathrm{r}=-$ 0,49, $\mathrm{p}=0,028)$ como no escore de Utilização dos Serviços de Saúde $(r=-0,52, p=0,019)$. Quando se aumenta o número de visitas ao médico, há uma piora na Avaliação Geral da Saúde ( $r=-0,47, p=0,039)$ e também na utilização do serviço de saúde $(r=-0,56$, $\mathrm{p}=0,011$ ). O estudo de GORTMAKER e col. (1998) não fez a análise de correlação entre os domínios e os marcadores de Utilização dos Serviços de Saúde nesta faixa etária.

Pode-se concluir que, na faixa etária de 12 a 20 anos, apesar do tamanho da amostra, houve correlações significativas nos domínios de Atividades Pessoais e Sociais e de Utilização dos Serviços de Saúde em relação ao número de noites passadas no hospital. Houve também correlações significativas nos domínios de Avaliação Geral da Saúde e de Utilização dos Serviços de Saúde em relação ao número de visitas ao médico.

$\mathrm{Na}$ análise da reprodutibilidade para esta faixa etária, verifica-se que não houve diferenças de médias entre os escores dos domínios do questionário de qualidade de vida quando se considera o teste e o resteste.

Com relação ao coeficiente de correlação intraclasse $\left(r_{i c c}\right)$ ele apresentou valores superiores a 0,80 nos domínios de Estado Físico e Saúde Psicológica e valores significativos e iguais a 0,58 e 0,62 nos domínios de Sintomas ou Sinais e Avaliação Geral da Saúde, respectivamente. Os domínios de Atividades Pessoais e Sociais e Utilização dos Serviços de Saúde não apresentaram $r_{\text {icc }}$ estatisticamente significativos. Como já discutido para as outras faixas etárias, houve somente um pequeno número de observações que tiveram escores diferentes entre o teste e o reteste (pouca variabilidade dos escores), uma vez que a grande parte das crianças apresentou escores idênticos ou semelhantes nas duas entrevistas.

Os gráficos de Bland-Altman, para a faixa etária de 12 a 20 anos, mostraram uma boa concordância entre o teste e o reteste para os escores de qualidade de vida, em quase 
todos os domínios, com exceção do domínio de Avaliação do Estado Físico. Pode-se concluir que o questionário de qualidade de vida se manteve estável entre as duas entrevistas mostrando com isso uma boa reprodutibilidade.

\subsubsection{Escala de Auto- Eficácia}

Para se verificar à adesão aos medicamentos anti-retrovirais em crianças e adolescentes com HIV/Aids foi utilizada a escala de auto-eficácia para seguir prescrição anti-retroviral em pacientes com HIV/Aids. Essa escala avalia expectativa de autoeficácia em situações difíceis para seguir a prescrição anti-retroviral. Entende-se por expectativa de auto-eficácia o julgamento do sujeito sobre sua habilidade para desempenhar com sucesso um padrão específico de comportamento. Dessa forma, a expectativa de auto-efiććcia para tomar medicamentos conforme a prescrição é a convicção na capacidade pessoal de controlar as circunstâncias que possam dificultar o seguimento regular da prescrição e realizar com sucesso tal comportamento (LEITE e col. 2002). A escala foi validada por LEITE e col. (2002) em uma amostra de 60 pacientes adultos que freqüentavam um ambulatório para pacientes em estágio avançado da doença (hospital-dia). Esta escala é composta de 21 itens e é fácil e rápida de ser aplicada.

Neste estudo a escala foi adaptada para que os pais/cuidadores respondessem pelas crianças/adolescentes. As propriedades psicométricas do instrumento foram verificadas por meio do $\alpha$ do Cronbach, da análise da validade de constructo e da análise de sua reprodutibilidade.

O escore-1 de auto-eficácia gerado pela análise fatorial é um escore composto pelas questões que melhor representam auto-eficácia na amostra do estudo. Para que este esçore seja calculado são necessários conhecimentos de estatística, em especial, de análise fatorial. Já o escore-2 de auto-eficácia é mais fácil de ser calculado (porcentagem simples). Por isso, para o usuário leigo recomenda-se que seja utilizado o escore - aqui 
denominado - 2 de auto-eficácia, principalmente pelo fato de que os resultados da validação e reprodutibilidade foram muito semelhantes para os dois escores.

A boa consistência interna da escala de auto-eficácia nas faixas etárias de 6 meses a 4 anos, 5 a 11 e 12 a 20 anos $(\alpha=0,99, \alpha=0,89$ e $\alpha=0,86$, respectivamente) e na amostra total $(\alpha=0,87)$ evidencia a alta correlação entre os itens da escala sugerindo que a escala é confiável para se medir auto-eficácia em crianças e adolescentes com HIV/Aids. O $\alpha$ de Cronbach obtido para a amostra total foi semelhante àquele encontrado no estudo de LEITE e col. (2002).

Em resumo, embora a consistência interna da faixa etária de 6 meses a 4 anos tenha que ser vista com certo cuidado por conta do reduzido número de crianças, as duas faixas etárias de crianças maiores apresentaram consistência acima de 0,85. Esses resultados estão de acordo com aqueles apresentados na validação da escala para adultos com HIV/Aids ( $\alpha$ Cronbach=0,96) indicando que esses 21 itens também são uma medida confiável para avaliar auto-eficácia em crianças e adolescentes com HIV/Aids, sob a perspectiva dos pais/cuidadores/responsáveis.

$\mathrm{Na}$ análise fatorial exploratória obteve-se um único fator que explicou $31 \%$ da variância acumulada. Como resultado desta análise obtive-se a geração do escore padronizado de auto-eficácia. No estudo de LEITE e col. (2002), na análise fatorial da escala obteve-se um fator que explicou mais de $50 \%$ da variância acumulada e a geração do escore padronizado de auto-eficácia. Conclui-se que os resultados da análise fatorial são semelhantes ao do estudo que validou a escala de auto-eficácia, embora com menor porcentagem de variância acumulada.

A escala de auto-eficácia conseguiu discriminar crianças/adolescentes aderentes ao tratamento anti-retroviral daquelas não aderentes, quando se considera a amostra total, tanto para escore-1 quanto para o escore-2. Os escores médios de auto-eficácia foram menores para os pacientes não-aderentes ao tratamento anti-retroviral, quando comparados com os pacientes aderentes. Os resultados da comparação de médias entre grupos para a amostra total são semelhantes aos encontrados no estudo que originou a escala (LEITE e col., 2002). Quando se consideram as faixas etárias específicas, o 
tamanho da amostra fica reduzido e apenas na faixa de 5 a 11 anos, o escore-1 de autoeficácia conseguiu discriminar grupos de pacientes aderentes e não aderentes ao tratamento anti-retroviral. Para a faixa etária de 12 a 20 anos, seriam necessárias, pelo menos, 20 em cada grupo $(\alpha=0,05$ e $\beta=0,20)$ de pacientes para se obter diferenças estatisticamente significativas.

Os autores da escala de auto-eficácia não verificaram a correlação da escala com parâmetros clínicos, porém neste estudo esta análise foi feita.

Compatível com a hipótese de que pacientes que são aderentes ao tratamento anti-retroviral têm uma diminuição da carga viral e, conseqüentemente, uma melhora nos níveis de células de defesa CD4 (PENEDO e col., 2003, STORM e col., 2005) os escores 1 e 2 de auto-eficácia foram correlacionados com a carga viral e CD4. Como resultado obteve-se um coeficiente de correlação positivo e estatisticamente significativo entre o escore-2 de auto-eficácia e CD4, quando se considerou a amostra total. Na análise da correlação por faixa etária, somente a de 5 a 11 anos apresentou coeficientes de correlação estatisticamente significativos entre o escore- 2 de auto-eficácia e CD4 $(r=0,38 ; p=0,039)$ e entre o escore- 2 e carga viral $(r=-0,50, p=0,030)$. A validade concorrente tanto na faixa etária de 6 meses a 4 anos como na de 12 a 20 foi prejudicada pelo tamanho da amostra. Para se obter um coeficiente de correlação de 0,50 seriam necessárias pelo menos 29 pessoas nestas faixas etárias, o que não ocorreu, pois somente havia 3 crianças na faixa de 6 meses a 4 anos e 20 na de 12 a 20 anos.

A análise da reprodutibilidade da escala de auto-eficácia também foi inédita neste estudo, pois o estudo que gerou a escala não fez a reprodutibilidade da mesma.

Quando se considerou as faixas etárias, não foram encontradas diferenças estatisticamente significativas nas médias dos escores 1 e 2 de auto-eficácia quando comparou-se a primeira (teste) e a segunda entrevista (reteste). Quando a amostra total fói considerada, não houve diferença estatisticamente significativa na média do escore-1 de auto-eficácia quando se comparou a primeira e a segunda entrevista, já para o escore2 de auto-eficácia, ocorreu uma diferença de média estatisticamente significativa entre as duas entrevistas. Esta diferença ocorreu devido aos escores de auto-eficácia de dois 
pacientes que foram, $65 \%$ e $89 \%$, na primeira entrevista e $95 \%$ e $100 \%$, na segunda entrevista.

Os coeficientes de correlação intra-classe dos escores 1 e 2 de auto-eficácia foram estatisticamente significativos tanto para a amostra total como para as faixas etárias. Os gráficos de Bland-Altman também mostraram uma boa concordância entre o teste e o reteste para os escores de auto-eficácia.

Os resultados da análise da reprodutibilidade da escala de auto-eficácia mostram que ela se manteve estável entre as duas entrevistas, evidenciando assim, uma boa reprodutibilidade.

Concluindo, a escala de auto-eficácia apresentou uma boa consistência interna e boa reprodutibilidade nas 3 faixas etárias estudadas e na amostra total. Quando se considera a amostra total, a escala de auto-eficácia apresenta validade de constructo 


\section{CONSIDERAÇÕES FINAIS}

Os questionários de qualidade de vida para as faixas etárias de 5 a 11 anos e de 12 a 20 anos mostraram uma boa consistência interna na maioria dos domínios. $O$ questionário de qualidade de vida para a faixa etária de 6 meses a 4 anos necessita de uma redução nas questões que compõem os domínios a fim de se obter melhor consistência interna.

Novos estudos para aprimorar o questionário de avaliação da qualidade de vida devem ser feitos. Estes estudos devem focar nos seguintes aspectos:

- Tentar reduzir o número de questões do questionário de avaliação da qualidade de vida, afim de que o instrumento fique mais fácil e rápido de ser aplicado na prática do cuidado às crianças e adolescentes com HIV/Aids;

- Analisar, qualitativamente, o que os pais/cuidadores entendem por qualidade de vida e qualidade de vida relacionada à saúde. A avaliação destas questões qualitativas poderiam contribuir para o processo de redução do número de questões que compõem o questionário.

- Analisar uma forma de se obter as respostas de qualidade de vida das próprias crianças/adolescentes.

Vale colocar, ainda, que o questionário de avaliação da qualidade de vida pode ser implementado na prática da pesquisa pediátrica procurando subsidiar a família e a equipe de saúde a entender se e como ocorrem alterações na qualidade de vida das crianças/adolescentes no decorrer da doença.

Além disso, estudos futuros devem ser realizados para se conhecer os fatores que possam estar associados à avaliação da qualidade de vida em crianças e adolescentes com HIV/Aids. Uma vez conhecidos estes fatores, tanto a equipe de saúde como a família podem atuar, na medida do possível, para buscar uma melhoria da qualidade de vida das crianças/adolescentes com HIV/Aids. 
Com relação à escala de auto-eficácia, ela pode ser utilizada na prática da pesquisa pediátrica para identificar pacientes com maior risco para a não adesão ao tratamento anti-retroviral e assim, fornecer subsídios para intervenções junto a estes pacientes. Recomenda-se que o escore baseado na soma dos itens - escore-2 - seja utilizado na prática clínica por ser mais fácil de ser calculado (porcentagem simples). 


\section{CONCLUSÕES}

- Como um primeiro produto deste trabalho tem-se a versão em português do questionário Quality of Life Assessment, para as três faixas etárias, a saber 6 meses a 4 anos, 5 a 11 anos e 12 a 20 anos.

- O questionário de qualidade de vida na faixa etária de 6 meses a 4 anos apresentou uma boa consistência interna somente no domínio de Sintomas ou Sinais. Mostrou capacidade discriminante no domínio de Estado Físico e correlações significativas com marcadores clínicos e/ou de utilização dos serviços de saúde nos domínios de Resistência Física, Atividades Sociais e Pessoais, Utilização dos Serviços de Saúde e Sintomas ou Sinais. A análise fatorial confirmatória mostrou que o número de questões pode ser reduzido, e obteve-se uma boa reprodutibilidade do questionário.

- O questionário de qualidade de vida na faixa etária de 5 a 11 anos apresentou boa consistência interna em praticamente todos os domínios, com exceção daquele de Resistência Física. Mostrou capacidade discriminante nos domínios de Avaliação Geral da Saúde, Estado Físico, Saúde Psicológica e Sintomas ou Sinais e correlação estatisticamente significativa apenas entre o domínio de Utilização dos Serviços de Saúde e o número de visitas ao médico. A análise fatorial confirmatória mostrou que o número de questões pode ser reduzido e o questionário apresentou uma boa reprodutibilidade.

- O questionário de qualidade de vida na faixa etária de 12 a 20 anos apresentou boa consistência interna em quase todos os domínios, com exceção daqueles denominados de "apoio". Mostrou capacidade discriminante no domínio de Sintomas ou Sinais e correlações significativas com marcadores clínicos e/ou de utilização dos serviços de saúde nos domínios de Avaliação Geral da Saúde, Atividades Pessoais e Sociais, Utilização dos Serviços de Saúde e Sintomas ou Sinais. A análise fatorial confirmatória mostrou que o número de questões pode ser reduzido e houve também uma boa reprodutibilidade. 
- A escala de auto-eficácia apresentou uma boa consistência interna e boa reprodutibilidade nas 3 faixas etárias estudadas e na amostra total. A escala apresentou validade de constructo na faixa etária de 5 a 11 anos, bem como para a amostra total. 


\section{REFERÊNCIAS}

Bandura A. Self-efficacy: Toward a unifying theory of behavioral change. Psychological Review. 1977;84:191-215.

Bastos FI. AIDS na Terceira Década. Rio de Janeiro: Editora Fiocruz; 2006.

Bastos FI, Buchalla CM, Ayres JRCM, Silva LJ. Resposta Brasileira à epidemia de HIV/AIDS, 2001-2005 [editorial]. Revista de Saúde Pública. 2006;40(Supl):1-2.

Berzon RA, Leplège AP, Lohr KN, Lenderking WR, Wu AW. Summary and recomendations for future research. Quality of Life Research. 1997;6:601-605.

Bland JM, Altman DG. Statistical Methods for assessing agreement between two methods of clinical measurement. Lancet. 1986;i:307-310.

Brito AM, Souza JL, Luna CF, Dourado I. Tendência da transmissão vertical de Aids após terapia anti-retroviral no Brasil. Rev Saúde Pública. 2006;40(Supl):18-22.

Brook RH, Ware JE, Avery AD, Stewart AL, Donald CA, Rogers WH et al. Overview of adult health status measures fielded in Rand's health insurance study. Medical Care. 1979;17(7-Supl):1-131.

Buchalla CM. AIDS: o surgimento e a evolução da doença. In: Monteiro CM. Velhos e novos males da saúde no Brasil: a evolução do país e suas doenças. 2. ed. rev. e aumentada. São Paulo: Hucitec, Nupens/USP; 2006. p.331-356.

Bucciardini R, Wu AW, Floridia M, Fragola V, Ricciardulli D, Tomino C et al. Quality of life outcomes of combination zidovudine-didanosine-nevirapine and zidovudine- 
didanosine for antiretroviral-naive advanced HIV-infected patients. AIDS. 2000;14:2567-2574.

Burgess A, Dayer M, Catalan J, Hawkins D, Gazzard B. The reliability and validity of two HIV-specific health-related quality of life measures: a preliminary analysis. AIDS. 1993;7:1001-1008.

Butensky EA, RN, MSN, CPNP. The role of nutrition in pediatric HIV/AIDS: A review of micronutrient research. Journal of Pediatric Nursing, 2001;16(6):402-411.

CDC - Centers for Diseases Control and Prevention. Recommendations of the U.S. public health service task force on the use of zidovudine to reduce perinatal transmission of human immunodeficiency virus. MMWR. 1994; 3:RR-11.

Connor EM, Sperling RS, Gelber R, Kiselev P, Scott G, O’Sullivan MJ et al. Reduction of maternal-infant transmission of human immunodeficiency virus type 1 with zidovudine treatment. N Engl J Med. 1994; 331(18): 1173-80.

Copfer AE, Ampel NM, Hughes TE, Gregor KJ, Dols CL, Coons SJ et al. The use of two measures of health-related quality of life in HIV-infected individuals: a crosssectional comparison. Quality of Life Research. 1996;5:281-286.

CRT-DST/AIDS - Centro de Referência e Treinamento em DST/AIDS. Boletim Epidemiológico [relatório na internet]. São Paulo; 2001[acesso em 18 abr 2007]. Disponível em http://www.crt.saude.sp.gov.br/dados boletins.htm.

CRT-DST/AIDS - Centro de Referência e Treinamento em DST/AIDS. Boletim Epidemiológico [relatório na internet]. São Paulo; 2005[acesso em 18 abr 2007]. Disponível em http://www.crt.saude.sp.gov.br/dados_boletins.htm. 
De Boer JB, Van Dam FSAM, Sprangers MAG. Health-related quality-of-life evaluation in HIV-infected patients. PharmacoEconomics. 1995; 8(4): 291-304.

Dourado I, Veras MASM, Barreira D, Brito AM. Tendências da epidemia de Aids no Brasil após a terapia anti-retroviral. Rev Saúde Pública. 2006;40(Supl):9-17.

Drotar D. Measuring Health-Related Quality of Life in Children and Adolescents: Implications for Research and Practice. Mahwah, NJ: Lawrence Erlbaum Associates; 1998.

Drotar D, Levi R. Critical issues and needs in health-related quality of life assessment of children and adolescents with chronic health condition. In: Drotar D. Measuring HealthRelated Quality of Life in Children and Adolescents: Implications for Research and Practice. Mahwah, NJ: Lawrence Erlbaum Associates; 1998. p. 3-23.

Dyke RBV, Lee S, Johnson GM, Wiznia A, Mohan K, Stanley K et al. Reported adherence as a determinant of response to highly active antiretroviral therapy in children who have human immunodeficiency virus infection. Pediatrics. 2002;109(4):1-7.

Eiser C, Morse R. Quality-of-life measures in chronic diseases of childhood. Health Technology Assessment. 2001;5(4):1-95.

Farrell J. A assustadora história das pestes e epidemias. São Paulo: Ediouro; 2003.

Farquhar M. Definitions of quality of life: A taxonomy. J Advanced Nursing. $1995 ; 22: 502-508$.

Gallo R. Caça ao vírus: câncer e retrovírus humano. São Paulo: Siciliano; 1994. 
Galvão MTG, Cerqueira ATAR, Machado JM. Avaliação da qualidade de vida de mulheres com HIV/AIDS através do HAT-Qol. Cad Saúde Pública. 2004;20(2):430-437.

Gaughan DM, Hughes MD, Seage III GR, Selwyn PA, Carey VJ, Gortmaker SL et al. The prevalence of pain in pediatric human immunodeficiency virus/acquired immunodeficiency syndrome as reported by participants in the pediatric late outcomes study (PACTG 219). Pediatrics. 2002;109:1144-1152.

Gibb DM, Goodall RL, Giacomet V, MCgee L, Compagnucci A, Lyall H. Adherence to prescribed antiretroviral therapy in human immunodeficiency virus-infected children in the PENTA 5 trial. Pediatr Infect Dis J. 2003;22:56-62.

Gortmaker SL, Lenderking WR, Clark C, Lee S, Fowler MG, Oleske JM, The ACTG 219 Team. Development and use of a pediatric quality of life questionnaire in AIDS clinical trials: reliability and validity of the general health assessment for children. In: Drotar D. Measuring Health-Related Quality of Life in Children and Adolescents: Implications for Research and Practice. Mahwah, NJ: Lawrence Erlbaum Associates; 1998. p. 219-235.

Gortmaker SL, Walker DK, Weitzman M, Sobol AM. Chronic conditions, socioeconomic risks, and behavioral problems in children and adolescents. Pediatrics. 1990;85:267-276.

Hasselmann MH e Reichenheim M E. Adaptação transcultural da versão em português da Conflict Tactics Scales Form R (CTS-1), usada para aferir violência no casal: equivalências semântica e de mensuração. Cadernos de Saúde Pública. 2003;19:10831093. 
Herdman M, Fox-Rushby J e Badia X. A model of equivalence in the cultural adaptation of HRQoL instruments: the universalist approach. Quality of Life Research.1998, 7:323335 .

Hirschfeld S, Moss H, Dragisic K, Smith W, Pizzo PA. Pain in pediatric human immunodeficiency virus infection: incidence and characteristics in a single-institution pilot study. Pediatrics. 1996;98(3):449-452.

Jenney MEM, Campbell S. Measuring quality of life. Archives of disease in childhood. 1997;77:347-354.

JÖRESKOG KG, MOUSTAKI I. Factor analysis of ordinal variables with Full Information Maximum Likelihood. [acesso em 02 ago 2007]. Disponível em http://www.ssicentral.com/lisrel/techdocs/orfiml.pdf

Laufer M, Scott G. Medical management of HIV disease in children. Pediatrics Clinics of North America. 2000;47(1):127-153.

Lee GM, Gortmaker SL, McIntosh K, Hughes MD, Oleske J e Pediatric AIDS Clinical Trials Group Protocol 219C Team. Quality of life for Children and Adolescents: Impact of HIV Infection and Antiretroviral Treatment. Pediatrics. 2006;117:273-283.

Leite JCC, Drachler ML, Centeno MO, Pinheiro CAT, Silveira VL. Desenvolvimento de uma escala de auto-eficácia para adesão ao tratamento anti-retroviral. Psicologia: Reflexão e Crítica, 2002; 15(1): 121-133.

Lenderking WR, Testa MA, Katzenstein D, Hammer S. Measuring quality of life in early HIV disease: the modular approach. Quality of Life Research,1997;6:515-530. 
Lwin R, Melvin D. Annotation: Paediatric Infection. J. Child Psychol. Psychiat. $2001 ; 42(4): 427-438$.

Marques HHS, Latorre MRDO, DellaNegra M, Pluciennik AMA, Salomão MLM e Grupo de Pesquisadores do Enhancing Care Iniciative-ECI-Brazil. Falhas na identificação da infecção pelo HIV durante a gravidez em São Paulo,SP, 1998. Rev de Saúde Pública. 2002;36(4):385-92.

Matida LH, Silva MH, Tayra A, Succi RCM, Gianna MC, Gonçalves A et al. Prevention of mother-to-child transmission of HIV in São Paulo State, Brazil: an update. AIDS. 2005; 19(suppl 4): S37-S41.1

Mendes NF. Origem do HIV e da Epidemia. In: Veronesi R, Focaccia R, Lomar AV, editores. HIV/AIDS: etiologia, patogenia e patologia clínica: tratamento e prevenção. São Paulo: Editora Atheneu; 1999. p. 13-15.

McCardle P, Quatrano LA. Workshop on pediatric AIDS rehabilitation: A summary. Pediatric AIDS and HIV Infection. 1995;6(1):14-17.

McCormick MC, Gunn JB, Daniels KW, Turner J, Peckham GJ. The health and developmental status of very low-birth-weight children at school age. JAMA. 1992;267(16):2204-2208.

McDonnel KA, Gielen AC, Wu AW, O`Campo P, Faden R. Measuring health related quality of life among women living with HIV. Quality of Life Research. 2000;9:931940.

McSeweeny AJ, Creer TL. Health-related quality-of-life assessment in Medical Care. Disease-a-Month. 1995;1-72. 
Minayo MCS, Hartz ZMA, Buss PM. Qualidade de vida e saúde: um debate necessário. Ciência \& Saúde Coletiva. 2000;5(1):7-18.

Ministério da Saúde. AIDS - Leia antes de escrever. Brasília, DF; 2003 [acesso em 08 mar 2006]. Disponível em http://www.aids.gov.br/data/

Ministério da Saúde. Boletim Epidemiológico - Aids e DST. Dados Epidemiológicos do Brasil - Tabela IV Casos de aids segundo faixa etária por sexo e ano de diagnóstico. Brasil, 1980 - 2006 [relatório na internet]. Brasília, DF; 2006a [acesso em 15 mar 2007]. Disponível em http://www.aids.gov.br/data/

Ministério da Saúde. Boletim Epidemiológico - Aids e DST. Dados Epidemiológicos do Brasil - Tabela VIII Casos de aids em indivíduos com 13 anos de idade ou mais, segundo categoria de exposição hierarquizada por sexo e ano diagnóstico. Brasil, 1980 a 2006 [relatório na internet]. Brasília, DF; 2006b [acesso em 15 mar 2007]. Disponível em http://www.aids.gov.br/data/

Ministério da Saúde. Boletim Epidemiológico - Aids e DST. Dados Epidemiológicos do Brasil - Tabela VI Casos de aids em indivíduos menores de 13 anos de idade, segundo categoria de exposição hierarquizada por sexo e ano diagnóstico. Brasil, 1980 a 2006 [relatório na internet]. Brasília, DF; 2006c [acesso em 15 mar 2007]. Disponível em http://www.aids.gov.br/data/.

Ministério da Saúde. Consenso: Recomendações para profilaxia da transmissão vertical do HIV e terapia anti-retroviral em gestantes - 2006 [relatório na internet]. Brasília DF; 2006d [acesso em 21 mar 2007]. Disponível em http://www.aids.gov.br/. 
Ministério da Saúde. Guia de tratamento clínico da infecção pelo HIV em crianças. Secretaria de Vigilância em Saúde, Programa Nacional de DST e Aids. Brasília, DF; 2004.

Moraes CL, Hasselmann MH, Reichenheim ME. Adaptação transcultural para o português do instrumento "Revised Conflict Tactics Scales (CTS2)" utilizado para identificar violência entre casais. Cad Saúde Pública. 2002;18(1):163-176.

Neto JLA, Siciliano RF. Assessing efficacy by measuring $\mathrm{CD}_{4}$ counts and quality of life of AIDS patients treated with ritonavir, AZT and 3TC. BJID. 2000;4(4):173-182.

Newell ML, Borja MC, Peckham C, European Collaborative Study. Height, weight, and growth in children born to mothers with HIV-1 infection in Europe. Pediatrics. 2003;111(1):e52-60.

Nicolas J, Dazord A, Magnificat S. Evaluation of life quality for children infected by HIV: Validation of a method and preliminary results. Pediatr AIDS HIV Infect. 1996;7(4):254-60.

Nischal KC, Khopkar U, Saple DG. Improving adherence to antiretroviral therapy. Indian J Dermatol Venereol Leprol. 2005;71(5):316-320.

O'Neill C, ODonoghue GM, Archbold SM, Normand C. A cost-utility analysis of pediatric cochlear implantation. Laryngoscope. 2000;110:156-160.

Ortigão MB. AIDS em crianças: considerações sobre a transmissão vertical. Cad Saúde Pública. 1995;11(1):142-148. 
Penedo FJ, Gonzalez JS, Dahn JR, Antoni M, Malow R, Costa P et al. Personality, quality of life and HAART adherente among men and women living with HIV/AIDS. Journal of Psychosomatic Research. 2003;54:271-278.

Pereira MG. Epidemiologia teoria e prática. Rio do Janeiro, RJ: Guanabara Koogan S.A.; 1995a. Aferição dos eventos; p.358-376.

Pereira MG. Epidemiologia teoria e prática. Rio do Janeiro, RJ: Guanabara Koogan S.A.; 1995b. Validade de uma Investigação; p.326-336.

Pluciennik AMA. Transmissão materno infantil do vírus da imunodeficiência humana adquirida: quanto custa não prevenir [tese de doutorado]. São Paulo: Faculdade de Saúde Pública da USP]; 2003.

Programa Municipal de DST/Aids de São Paulo. Boletim Epidemiológico de Aids/DST e Hepatites B e C do Município de São Paulo. [relatório na internet]. São Paulo, SP; 2007. [acesso em 23 jul 2007]. Disponível em http://www10.prefeitura.sp.gov.br/dstaids/novo site/

Reichenheim ME, Moraes CL. Operacionalização de adaptação transcultural de instrumentos de aferição usados em epidemiologia. Rev Saúde Pública. 2007;41(4):665673.

Revicki DA, Wu AW, Murray MI. Change in clinical status, health status, and health utility outcomes in HIV-infected patients. Medical Care. 1995;33(4-Supl):AS173AS182. 
Rotta NT, Silva AR, Silva CL, Silva FF, Silva MG, Santos, LO et al. Follow-up of patients with vertically-acquired HIV infection who are more then 9 years old. Journal of tropical pediatrics. 2003;49:253-255.

Rouquayrol MZ, Veras FMF, Façanha MC. Doenças transmissíveis e modos de transmissão. In: Rouquayrol MZ e Almeida Filho N. Epidemiologia e saúde. 5. ed. Rio de Janiero: Medsi; 1999. p. 215-267.

Santos ECM. Qualidade de Vida de Portadores do Vírus da Imunodeficiência Humana [dissertação de Mestrado]. São Paulo: Faculdade de Saúde Pública da USP; 2003.

Scliar M. Do mágico do social: trajetória da saúde pública. São Paulo: Senac; 2002.

Seidl EMF. Pessoas que vivem com HIV/AIDS: Configurando Relações entre Enfrentamento, Suporte Social e Qualidade de Vida [tese de doutorado]. Brasília: Instituto de Psicologia da Universidade de Brasília; 2001.

Seidl EMF, Zannon CMLC. Qualidade de vida e saúde: aspectos conceituais e metodológicos. Cad Saúde Pública. 2004;20(2);580-588.

Sengendo J, Nambi J. The psychological effect of orphanhood: a study of orphans in Rakai district. Health Transit Rev. 1997;7(Supl):105-24.

Shah CA. Adherence to high activity antiretroviral therapy (HAART) in pediatric patients infected with HIV: Issues and interventions. The Indian Journal of Pediatrics. 2007;74(1):55-60.

Sharma S. Applied multivariate techniques. New York: John Wiley \& Sons, 1996 
Starace F, Massa A, Amico KR, Fisher JD. Adherence to antiretroviral therapy: An empirical test of the information-motivation-behavioral skills model. Health Psychol. 2006;25(2):153-162.

Stein REK, Jessop DJ. Functional status II(R). A measure of child health status. Medical Care. 1990;28(11):1041-1055.

Stewart AL, Hays RD, Ware JE. The MOS Short-form general health survey. Reliability and validity in a patient population. Medical Care. 1988;26(7):724-737.

Storm DS, Boland MG, Gortmaker SL, He Y, Skurnick J, Howland L, Oleske JM e Pediatric AIDS Clinical Trials Group Protocol 219 Study Team. Protease inhibitor combination therapy, severity of illness, and quality of life among children with perinatally acquired HIV-1 infection. Pediatrics. 2005;115:173-182.

Streiner DL. Starting at the beginning: an introduction to coefficient Alpha and Internal Consistency. Journal of Personality Assessment. 2003; 80(1): 99-103.

Streiner DL e Norman GR. Health measurement scales. A practical guide to their development and use. 3 ed. Oxford: Oxford University Press, 2003.

Szwarcwald CL, Bastos FI, Esteves MAP, Andrade CLT. A disseminação da epidemia da AIDS no Brasil, no período de 1987-1996: uma análise espacial. Cad Saúde Pública. 2000; 16(Sup. 1): 7-19.

Tanner JM. Growth at Adolescence. 2. ed. Oxford: Blackwell Scientific Publications, 1962. 
Tess BH, Rodrigues LC, Newell ML, Dunn DT, Lago TD. Breastfeeding, genetic, obetetric and other risk fators associated with mother-to-child transmission of HIV-1 in São Paulo State, Brazil. AIDS. 1998; 26:12(5): 513-20.

Testa MA, Lenderking WR. Quality of life considerations in AIDS clinical trials. In: Finkelstein DM, Schoenfeld DA. AIDS clinical trials. New York: Wiley-Liss, Inc.; 1995.

Testa MA, Simonson DC. Assessment of quality-of-life outcomes. The New England Journal of Medicine. 1996; 334(13):835-840.

The WHOQOL Group. Development of the WHOQOL: rationale and current status. Int J Ment Health. 1994;23(3):24-56.

Tostes MA, Chalub M, Botega NJ. The quality of life of HIV-infected women is associated with psychiatric morbidity. AIDS Care. 2004;16(2):177-186.

UNAIDS - Joint United Nation Programme on HIV/AIDS. Report on the global AIDS epidemic: Executive summary [relatório na internet]. Geneva; 2006 [acesso em 15 mar 2007]. Disponível em: http://www.unaids.org/en/HIV_data/epi2006.

Veloso VG, Vasconcelos AL, Grinsztejn B. Prevenção da transmissão vertical no Brasil. In: Boletim Epidemiológico - Aids XII, n 3, semana epidemiológica 22 a 34 junho/agosto 1999.

Weinfurt KP, Willke RJ, Glick HA, Freimuth WW, Schulman KA. Relationship between CD4 count, viral burden, and quality of life over time in HIV-1-infected patients. Medical Care. 2000;38(4):404-410. 
WHO. World Health Organization. Physical Status: the use and interpretation of anthropometry. Report of a WHO Expert Committee. Geneva; 1995.

WHOQOL HIV Group. WHOQOL-HIV for quality of life assessment among people living with HIV and AIDS: results from the field test. AIDS Care. 2004;16(7):882-889.

Wolters PL, Brouwers P, Moss HA, Pizzo PA. Adaptive behavior of children with symptomatic HIV infection before and after zidovudine therapy. J Pediatr Psychol. 1994;19(1):47-61.

Wu AW. Quality of life assessment comes of age in the era of highly active antiretroviral therapy. AIDS. 2000;14:1449-1451.

Wu AW, Hays RD, Kelly S, Malitz F, Bozzete. Applications of the medical outcomes study helath-related quality of life measures in HIV/AIDS. Quality of Life Research. 1997a;6:531-554.

Wu AW, Revicki DA, Jacobson D, Malitz FE. Evidence for reliability, validity and usefulness of the Medical Outcomes Study HIV health survey (MOS-HIV). Quality of Life Research. 1997b;6:481-493.

Wu AW, Rubin HR, Mathews WC, Brysk LT, Bozzette SA, Hardy WD et al. Functional status and Well-Being in a placebo-controlled trial of zidovudine in early symptomatic HIV infection. Journal of Acquired Immune Deficiency Syndromes. 1993;6:452-458.

Wu AW, Rubin HR, Mathews WC, Ware JE, Brysk LT, Hardy WD, Bozzette SA, Spector SA, Richman DD. A health status questionnaire using 30 items from the medical outcomes study. Preliminary validation in persons with early HIV infection. Medical Care. 1991;29(8):786-798. 
ANEXOS 


\section{Anexo 1: Termo de consentimento livre e esclarecido}

\section{Termo de Consentimento Livre e Esclarecido para o Centro de Referência e Treinamento em DST/AIDS de São Paulo - CRT/SP}

\section{Investigadores: Dra. Mariliza Henrique da Silva, Luciana Scarlazzari Costa - doutoranda.}

Convidamos você, que é o pai, mãe ou cuidador de uma das crianças que faz o acompanhamento ou tratamento no Hospital Dia do Centro de Referência e Treinamento DST/AIDS, para participar dessa pesquisa. Esse estudo visa conhecer a qualidade de vida em crianças e adolescentes infectados pelo HIV/AIDS e verificar o quanto a doença afeta a mesma.

A sua participação é totalmente voluntária e a qualquer momento você pode deixar de participar, se assim quiser. A eventual recusa não prejudicará o acompanhamento ou tratamento de saúde de seu filho(a) no Hospital Dia do CRT DST/AIDS. Os pesquisadores se comprometem a manter sigilo das informações prestadas. Todas essas informações serão utilizadas para fins científicos sem jamais serem expostos os dados de identificação ou menos ainda, seus dados pessoais.

No início serão gravadas as respostas para as seguintes perguntas:

"O que o Sr.(a) considera uma boa qualidade de vida? Por que? E uma boa qualidade de vida relacionada à saúde? Por que? E uma má qualidade de vida? Por que?".

A seguir o gravador será desligado e continuaremos a fazer outras perguntas. $\mathrm{Na}$ gravação não há a identificação de quem está respondendo as questões. As fitas serão transcritas por uma pessoa que não conhecerá a identidade do entrevistado e nós nos comprometemos a destruir a gravação.

Durante o estudo você será solicitado a responder questões sobre o estado de saúde, o comportamento, as atividades diárias de seu filho (a) bem como o seu quadro de sintomas e a utilização do serviço de saúde. Também serão coletados do prontuário de seu filho(a) os dados referentes aos exames de carga viral de HIV e das contagens de células de defesa (CD4+) atual e no início de sua matrícula neste serviço. Esse estudo não inclui a administração de remédios e não influencia no acompanhamento ou tratamento de seu filho (a).

Os riscos são mínimos. Eventualmente poderão ocorrer alguns desconfortos frente a algumas questões, entretanto será oferecido suporte psicológico continuado pela equipe do estudo.

Um potencial benefício desse estudo é que ele permitirá, eventualmente, que os profissionais de saúde identifiquem problemas que podem não ter sido notados por você, e dessa forma orientá-lo sobre como proceder para melhorar a qualidade de vida de seu filho (a). 
Em caso de dúvidas ou perguntas referentes a sua participação no estudo, você poderá entrar em contato com a $\mathrm{Sr}^{\mathbf{a}}$ Luciana Scarlazzari Costa, no telefone: (0XX11 4198-5393) ou com a Dr ${ }^{2}$ Mariliza Henrique da Silva (0XX11 5087-9877).

\section{CONSENTIMENTO PÓS-ESCLARECIDO}

Declaro que autorizo a participação do menor de idade no presente protocolo de pesquisa.

Declaro também que, após convenientemente esclarecido pelo pesquisador e ter entendido o que me foi explicado, consinto em participar do presente Protocolo de Pesquisa.

São Paulo, de de 2005.

assinatura do sujeito da pesquisa ou responsável legal

assinatura do pesquisador

(carimbo ou nome Legível) 


\section{Anexo 2: Características sócio-demográficas e familiares das crianças/adolescentes}

Características sócio-demográficas e clínicas da criança/adolescente

Número do paciente:

...me do entrevistador

1. Data de preenchimento 1

2. Número do prontuário do paciente:

\section{Sexo}

masculino (1)

feminino (2)

4. Cor da pele:

$B(1) \quad P t(2) \quad P d(3) \quad A m(4) \quad$ Outros(5)

5. Data de Nascimento

1

6. Completou até que série?

7. Quantas horas por dia o paciente fica na escola?

8. Peso (últimos 3 meses)

…............. Kg

9. Altura (últimos 3 meses)

.................cm

10. Já teve a menarca ou semenarca?

$\operatorname{sim}(1) \quad$ não (0)

Se teve, foi com que idade?

11. Com quem a criança/adolescente mora?

família (1) casas de apoio (2)

12. Se morar em casas de apoio:

local em que fica:

quem é o cuidador?

Somente para as crianças que moram com alguma familia

Características dos familiares e moradores

\begin{tabular}{|c|c|c|c|c|c|}
\hline morador/familiar & sexo & idade & escolaridade & renda & ocupação \\
\hline \multicolumn{6}{|l|}{1.} \\
\hline \multirow{2}{*}{\multicolumn{6}{|c|}{$\frac{2 .}{3}$}} \\
\hline \multirow{2}{*}{\multicolumn{6}{|c|}{3.}} \\
\hline & & & & & \\
\hline \multicolumn{6}{|l|}{5.} \\
\hline \multicolumn{6}{|l|}{6.} \\
\hline \multirow{2}{*}{\multicolumn{6}{|c|}{\begin{tabular}{|l|}
8 \\
8
\end{tabular}}} \\
\hline & & & & & \\
\hline 10. & & & & & \\
\hline
\end{tabular}


nome do cuidador:

13. Uso de drogas ilícitas (maconha, etc.) nos últimos 3 meses

Pai não (0) sim (1) ignorado (9) Qual:

Mãe não (0) sim(1) ignorado (9) Qual:

14. Etilismo nos últimos 3 meses

Pai $\quad$ não (0) $\quad \operatorname{sim}(1) \quad$ parou (2) quando:.............................. ignorado (9)

Qual:

Quantidade:

Mãe não (0) $\operatorname{sim}(1) \quad$ parou (2) quando:................................ ignorado (9)

Qual:

Quantidade:

15. Tabagismo nos últimos 3 meses

Pai não (0) sim (1) parou (2) quando:

ignorado (9)

Tipo:

quantos por dia

Mãe não (0) sim (1) parou (2) quando: ignorado (9)

Tipo:

quantos por dia

16. Durante a gestação, a mãe (somente para as crianças que vivem com a mãe natural) Fez uso de droga ilícita:

não (0) $\quad \operatorname{sim}(1) \quad$ parou (2) quando:.................................. ignorado (9)

Qual:

Fez uso de bebida alcoólica:

não (0) $\quad \operatorname{sim}(1) \quad$ parou (2) quando:.................................. ignorado (9)

Qual:

Quantidade:

Fumou:

não (0) $\operatorname{sim}(1)$ parou (2) quando:

ignorado (9)

Quantos:.....................por dia 
Anexo 3: Questionário de avaliação da qualidade de vida

6 meses a 4 anos 


\section{INSTRUCÕES PARA O ENTREVISTADOR:}

- O seguinte questionário deve ser dado para os pais/cuidadores ou responsáveis antes da visita clínica e preferencialmente em uma área reservada e quieta (i.e. sala de exame ou outra sala). Os pais/cuidadores ou responsáveis precisam ser capazes de ler e devem ter a $4^{\mathrm{a}}$ série do ensino fundamental, para completar o questionário por si mesmos. Se isso não acontecer, o investigador deverá completar o questionário com o indivíduo. Este questionário deverá ser dado para os pais/cuidadores ou responsáveis que têm crianças com idades entre 6 meses e 4 anos.

- As questões de 1 a 7 da seção clínica devem ser completadas pelo investigador. As páginas 3-8 devem ser completadas pelos pais/responsáveis. Antes de dar o questionário para os pais/responsáveis, por favor, preencha o cabeçalho e destaque as páginas 1 e 2 .

- É muito importante que o pesquisador esteja familiarizado com o conteúdo e formato do questionário antes de entregá-lo aos participantes do estudo. Na primeira visita para esse estudo, recomenda-se iniciar com a explicação aos pais/responsáveis acerca do formato das questões e como devem ser completadas.

- Cada questão tem o mesmo formato geral e contém vários itens. Observe que os respondentes sempre deverão CIRCULAR um número ou marcar um " $X$ " na categoria apropriada.

- Coletar o questionário completo antes da visita clínica. Antes de finalizar, revisar o questionário para verificar questões em branco. Se o participante esqueceu alguma questão, indique e solicite a ele/ela que complete a mesma.

\section{SECÃO CLÍNICA}

AS QUESTÕES DE 1 A 7 DEVEM SER COMPLETADAS PELO INVESTIGADOR:

COMPLETAR AS QUESTÕES 1 E 2 COM A AJUDA DOS PAIS/CUIDADORES OU

RESPONSÁVEIS ANTES DE FORNECER O QUESTIONÁRIO DE QUALIDADE DE VIDA

1. Nos últimos 12 meses, alguns dos eventos abaixo ocorreram?

a. Os pais perderam o emprego:

b. Algum membro da família deixou a casa:

c. Perdeu moradia ou teve que mudar:

d. Perda de benefícios (direitos): vale alimentação, auxílio desemprego.

e. Perda de seguro saúde:

f. Algum membro da família esteve hospitalizado:

g. Algum membro da família esteve muito doente:

h. Mudança do cuidador (responsável):

i. Separação dos pais:

j. Divórcio dos pais:

k. Detenção/Prisão dos pais:

1. Casamento dos pais:

m. Nascimento de irmão:

n. Mãe começou a trabalhar:

o. Início na escola ou mudou para uma nova escola:

p. Mudança na condição financeira dos pais:

q. Perda de amigo íntimo (da criança):

r. Morte na família:

Se houve morte na familia, quem morreu?

1-mãe 2-pai

3-irmão/irmã ou filhos de outros casamentos dos pais (sem vínculo biológico)

4-avós

9-outro membro da família 
a. A criança sabe que ela é infectada?

SE SIM, complete 'al'.

a1. Com qual idade a criança soube pela primeira vez da sua situação de infectada: (colocar 1 se desconhecido)

b. A criança está na escola?

c. A escola sabe do diagnóstico?

RESPONDER OS SEGUINTES ITENS DEPOIS QUE OS PAIS/CUIDADORES OU RESPONSÁVEIS TENHAM TERMINADO O QUESTIONÁRIO OU DEPOIS QUE VOCÊ TENHA CERTEZA DE QUE ISSO NÃO SERÁ POSSÍVEL:

5. Como o questionário foi preenchido?

Se responder '4', completar 'a' e PARAR.

1- auto-respondido pelos pais/cuidadores ou responsáveis

2- entrevista face a face feita pelo entrevistador

3- entrevista por telefone

4- não completado

Se Outro, especificar:[30]

9- outro, especificar

a. Se respondeu '4' - Não completado, indicar a razão:

1- recusa

2 - paciente não compareceu à consulta

3 - não houve tempo suficiente para entrevista

Se Outra razão, especifique: [30]

9 - outra razão

6. Quem respondeu as questões?

1 - mãe biológica

2 - pai biológico

3 - outro parente

4 - pais adotivos

5-pais substitutos

9 - outra pessoa

Se outra pessoa ou outro parente, especifique:[30]

7. Em que língua o questionário foi administrado?.

$$
\begin{aligned}
& 1 \text { - inglês } \\
& 2 \text { - espanhol } \\
& 3 \text { - francês } \\
& 4 \text { - creole } \\
& 5 \text { - português } \\
& 9 \text { - outro }
\end{aligned}
$$

Se outro, especifique:[30]

a. Qual o idioma que é falado em casa?

Se outro, especifique:[30]

$$
\begin{aligned}
& 1 \text { - inglês } \\
& 2 \text { - espanhol } \\
& 3 \text { - francês } \\
& 4 \text { - creole } \\
& 5 \text { - português } \\
& \text { 9- Outro }
\end{aligned}
$$

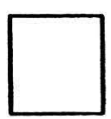


Número do paciente

Código da Instituição

\section{INSTRUCÕES AOS PAIS/CUIDADORES OU RESPONSÁVEIS:}

Por favor responda as questões circulando a melhor resposta. Não há questões certas ou erradas. Se você não entender o que significa determinada questão, não hesite em perguntar ao investigador. Por favor, responda da melhor maneira possível todas as questões.

I. Avaliação Geral da Saúde. Essas questões referem-se à saúde e comportamento de sua criança.

A. Em uma escala de 1 a 10: (sendo o 1 para muito ruim/pior e o 10 muito bom/ótimo) COMO SUA CRIANÇA TEM SE SENTIDO, EM MÉDIA, NOS ÚLTIMOS 3 MESES?

(Por favor, circule um número para cada questão)

pior do que

ele/ela já se sentiu melhor do que

ele/ela já se sentiu

1. De maneira geral?

\begin{tabular}{llllllllll}
1 & 2 & 3 & 4 & 5 & 6 & 7 & 8 & 9 & 10 \\
\hline 1 & 2 & 3 & 4 & 5 & 6 & 7 & 8 & 9 & 10 \\
\hline
\end{tabular}

2. Fisicamente?

$\begin{array}{lllll}2 & 3 & 4 & 5 & 6\end{array}$

$\begin{array}{lllll}6 & 7 & 8 & 9 & 10\end{array}$

B. Ao ler as questões abaixo, decida qual frase melhor descreverá como esteve a saúde da sua criança ao longo dos últimos 3 meses, então circule o número que melhor combina com a resposta que você escolher.

DURANTE OS ÚLTIMOS 3 MESES... (Por favor, circule um número para cada questão)

1. A saúde da minha criança é excelente:

\begin{tabular}{ccc}
$\begin{array}{c}\text { Nunca ou } \\
\text { raramente }\end{array}$ & $\begin{array}{c}\text { Durante } \\
\text { algum } \\
\text { tempo }\end{array}$ & $\begin{array}{c}\text { Quase } \\
\text { sempre } \\
\text { ou } \\
\text { sempre }\end{array}$ \\
\hline
\end{tabular}

2. Minha criança parece resistir a doença muito bem:

3. Minha criança parece menos sadia do que as outras crianças que eu conheço:

4. Minha criança é bastante suscetível a doenças que estão circulando:

5. Minha criança é pouco desajeitada:

6. Minha criança parece ter uma tendência a sofrer acidentes:

7. Quando minha criança está doente ou machucada, ela geralmente se recupera rapidamente: 


\section{Avaliação do estado físico}

Aqui estão algumas declarações que os pais/cuidadores ou responsáveis usam para descrever sua criança. Ao ler as questões abaixo, decida qual frase melhor descreverá como esteve o comportamento da sua criança ao longo dos últimos 3 meses, então circule o número que confere com a resposta que você escolher.

Pensando na sua criança, DURANTE OS ÚLTIMOS 3 MESES, teria ela...

(Por favor, circule um número para cada questão)

1. Se alimentado bem?

\begin{tabular}{ccc}
$\begin{array}{c}\text { Nunca ou } \\
\text { raramente }\end{array}$ & $\begin{array}{c}\text { Durante } \\
\text { algum } \\
\text { tempo }\end{array}$ & $\begin{array}{c}\text { Quase } \\
\text { sempre } \\
\text { ou } \\
\text { sempre }\end{array}$ \\
\hline 1 & 2 & 3
\end{tabular}

2. Dormido bem?

1

2

3

3. Parece contente e alegre?

1

2

3

4. Muda de humor sem razão aparente?

1

2

3

5. Comunica, pede o que está querendo?

1

2

3

6. Parece se sentir doente ou cansada?

1

2

3

7. Se ocupa fazendo coisas, brincando sozinha?

1

2

3

8. Parece animada, ativa e cheia de energia?

9. Parece irritada, zangada ou mal humorada?

10. Dorme a noite toda? 1

2

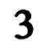

11. Reage aos seus estímulos?

2

3

12. Parece estar mais difícil de lidar do que o costume?.....

13. Parece interessada no que está acontecendo ao redor?

14. Reage com choro a pequenas coisas?

15. Depende de algum equipamento ou aparelho médico no seu dia a dia? 
III. Avaliação das atividades pessoais e sociais ( Marcar com "X" na linha próxima de sua resposta)

\section{A. DURANTE AS 4 ÚLTIMAS SEMANAS, QUANTOS DIAS...}

1. A sua criança ficou na cama (a maioria do tempo ou durante todo o dia) devido a alguma doença ou lesão/ferimento/acidente/machucado?

\begin{tabular}{|l|l|l|l|l|l|}
\hline 0 & $1-2$ & $3-5$ & $6-10$ & $11-15$ & \\
$(1)$ & $(3)$ & $>16$ & $(6)$ \\
\hline
\end{tabular}

2. A doença ou lesão manteve sua criança fora da escola/creche? (se este período for de férias escolares, diga em relação ao último mês em que a escola/creche estava aberta)

\begin{tabular}{|c|c|c|c|c|c|}
\hline $\begin{array}{l}\text { Não está } \\
\text { na escola } \\
(-1)\end{array} 0$ & $1-2 \frac{}{(2)}$ & $3-5$ & $6-10$ & $11-15 \frac{}{(5)}$ & $>16$ \\
\hline
\end{tabular}

B. Por favor, assinale somente uma resposta para cada questão:

1. DURANTE AS ÚLTIMAS 4 SEMANAS, sua criança teve alguma

(Marque uma) doença ou lesão que limitou ou impediu que ela fizesse alguma das atividades infantis tais como brincar com outras crianças ou participar de jogos e esportes?.

$\operatorname{sim}_{1}$ não

2. No geral, sua criança esteve capaz de participar das atividades rotineiras com as outras crianças? sim não

3. No geral, sua criança esteve limitada no tipo de brincadeira devido à sua saúde?

$\operatorname{sim}$ não

4. No geral, sua criança esteve limitada na quantidade, ou melhor, no tempo de brincar devido à sua saúde?.

5. Sua criança está envolvida em programa de estimulação precoce devido à sua saúde?

6. DURANTE AS ÚLTIMAS 4 SEMANAS, quem cuidou de sua criança na maioria do tempo durante os dias da semana? Se mais que um local, colocar o período em cada um (ex. manhã: creche; tarde: avo)

$\begin{array}{ll}\text { você } & 11 \\ \text { pai ou mãe/pais adotivos } & 12 \\ \text { avós } & 13 \\ \text { irmão ou irmã } & 14 \\ \text { alguém que não é parente } & 15 \\ \text { creche } & 16 \\ \text { maternal ou jardim da infância } & 17 \\ \text { casa de apoio } & 18 \\ \text { programa de estimulação precoce } & 19 \\ \text { Outra pessoa } & 20 \\ \text { Outros parentes } & 21\end{array}$

SE outros parentes, quais? 
IV. Utilização de serviços de saúde (Assinalar com "X" na linha próxima de sua resposta)

A. DURANTE AS ÚLTIMAS 4 SEMANAS...

1. QUANTAS NOITES a sua criança ficou no hospital?

\begin{tabular}{|c|c|c|c|c|c|}
\hline $0^{0}$ & $1-2$ & $3-5$ & 6-10 & $11-20$ & $>20_{(6)}$ \\
\hline
\end{tabular}

2. QUANTAS VISITAS sua criança fez ao ambulatório ou pronto-socorro para ver o médico, enfermeiro ou outro especialista?

\begin{tabular}{|l|l|l|l|l|l|}
\hline 0 & $1-2$ & $3-5$ & $6-10$ & $11-20$ & \\
$(1)$ & ${ }^{0}$ & 20 & $\frac{(5)}{(6)}$ \\
\hline
\end{tabular}

3. QUANTAS VEZES a sua criança recebeu visita de um enfermeiro ou outro profissional de saúde em sua casa?

\begin{tabular}{|l|l|l|l|l|l|}
\hline 0 & $1-2$ & $3-5$ & $3-10$ & $11-20$ & \\
\hline$(1)$ & & 320 & $\frac{(5)}{(6)}$ \\
\hline
\end{tabular}

4. QUANTAS VEZES você telefonou para uma clínica, médico, enfermeiro, ou outro profissional do serviço de saúde para uma consulta através do telefone acerca de sua criança?

\begin{tabular}{|c|c|c|c|c|c|}
\hline $0^{0}$ & $1-2 \frac{}{(2)}$ & $3-5$ & $6-10 \frac{}{(4)}$ & $11-20 \frac{}{(5)}$ & $>20 \frac{}{(6)}$ \\
\hline
\end{tabular}


B. Por favor, assinale somente uma alternativa para cada questão:

DURANTE AS ÚLTIMAS 4 SEMANAS, a sua criança apresentou

alguma doença ou lesão que necessitou receber algum medicamento, exceto vitaminas, receitado pelo médico?

$\operatorname{sim}$ não

SE NÃO, vá para a parte "C".

SE SIM, que tipo de medicação sua criança tomou?

1. medicamento para a dor?

$\operatorname{sim}_{1}$ não 2

2. antibióticos?

$\operatorname{sim}_{1}$ não $_{2}$

3. medicamentos para resfriado?

$\operatorname{sim}$ não

4. medicamentos para chiado no peito?

12

sim 'não

5. cremes, pomadas para lesões, feridas?

$\operatorname{sim}$ não

6. medicamentos contra diarréia?

12

sim não

C. A seguir há uma lista de tratamentos alternativos que você pode estar dando para a sua criança. Esses tratamentos são outros do que os medicamentos tradicionais. Desde a última consulta, a sua criança recebeu ou tomou algum dos seguintes?

a. ervas medicinais?

Quais?

$\operatorname{sim}$ não

b. vitaminas?

12

Quais?

sim não

c. acupuntura?

$\operatorname{sim}$ não

d. ioga?

sim não

12

e. aromaterapia?

sim não

f. foi a algum centro espírita ou outro tipo de centro para receber passes?

12

Qual?

$\operatorname{sim}$ não

g. utilizou algum tipo de cuidado por curandeiro, benzedeira e outros?

Qual?

sim não

h. tratamento com massagens?.......................................................... sim não

Qual?

12

i. homeopatia?

não

j. outros:

$\operatorname{sim}$ não 


\section{Sintomas ou sinais}

As questões a seguir perguntam acerca de SINTOMAS OU SINAIS que sua criança possa ter tido durante as últimas 4 semanas. Por favor, responda $O$ QUANTO DE DESCONFORTO os seguintes sinais ou sintomas causaram em sua criança DURANTE AS ÚLTIMAS 4 SEMANAS.

QUANTO DE DESCONFORTO A SUA CRIANÇA SENTIU COM ESSES SINTOMAS OU SINAIS?

(Por favor circule somente uma resposta para cada questão)

$\begin{gathered}\text { Nem um Muito pouco Pouco } \\ \text { pouco }\end{gathered}$
$\begin{gathered}\text { Moderada Muito Demais } \\ \text { mente } \\ \text { (mais ou }\end{gathered}$

1. dor física ou no corpo todo?

2. chiado, tosse?

$\begin{array}{llllll}1 & 2 & 3 & 4 & 5 & 6 \\ 1 & 2 & 3 & 4 & 5 & 6\end{array}$

3. náuseas, vômitos, dor abdominal, dor de estômago?.............................

4. diarréia? .

5. manchas, coceiras ou outros problemas de pele?

6. fadiga, cansaço, fraqueza?

7. tontura, delírio febril? ...

8. febre, suores noturnos, tremores e calafrios?

9. perda de apetite?

10. problemas de sono?.....

11. problemas nos olhos

ou para enxergar?

12. dor de cabeça?

s?...........

13. boca seca ou dolorida, problemas para engolir?....

14. dor ou aperto no peito?

15. dificuldade para

respirar ou pegar o ar?.......

16. nariz escorrendo ou problemas de sinusite?....... 17. dor no músculo, nas articulações (juntas) ou nos ossos?

\begin{tabular}{lllllll}
. & 1 & 2 & 3 & 4 & 5 & 6 \\
& 1 & 2 & 3 & 4 & 5 & 6 \\
\hline & 1 & 2 & 3 & 4 & 5 & 6
\end{tabular}

\begin{tabular}{llllll}
1 & 2 & 3 & 4 & 5 & 6 \\
\hline 1 & 2 & 3 & 4 & 5 & 6
\end{tabular}

$\begin{array}{llllll}1 & 2 & 3 & 4 & 5 & 6\end{array}$

18. dor, formigamento, dormência, paralisia nas mãos ou pés?....................... 19. dor de ouvido?

20. desconforto ou mal estar geral?. 
Anexo 4: Questionário de avaliação da qualidade de vida

5 a 11 anos 


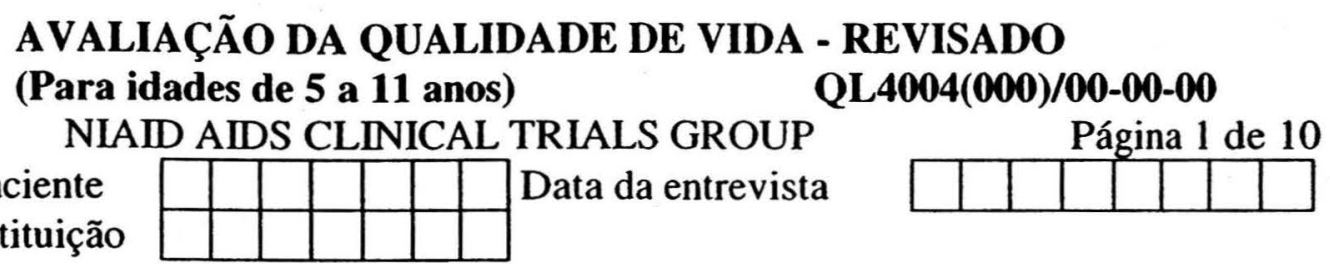

Número do paciente

Código da Instituição

\section{INSTRUCÕES PARA O ENTREVISTADOR:}

- O seguinte questionário deve ser dado para os pais/cuidadores ou responsáveis antes da visita clínica e preferencialmente em uma área reservada e quieta (i.e. sala de exame ou outra sala). Os pais/cuidadores ou responsáveis precisam ser capazes de ler e devem ter a $4^{\mathrm{a}}$ série do ensino fundamental, para completar o questionário por si mesmos. Se isso não acontecer, o investigador deverá completar o questionário com o indivíduo. Este questionário deverá ser dado para os pais/cuidadores ou responsáveis que têm crianças com idades entre 5 e 11 anos.

- As questões de 1 a 7 da seção clínica devem ser completadas pelo investigador. As páginas 3-10 devem ser completadas pelos pais/responsáveis. Antes de dar o questionário para os pais/responsáveis, por favor, preencha o cabeçalho e destaque as páginas 1 e 2 .

- É muito importante que o pesquisador esteja familiarizado com o conteúdo e formato do questionário antes de entregá-lo aos participantes do estudo. Na primeira visita para esse estudo, recomenda-se iniciar com a explicação aos pais/responsáveis acerca do formato das questões e como devem ser completadas.

- Cada questão tem o mesmo formato geral e contém vários itens. Observe que os respondentes sempre deverão CIRCULAR um número ou marcar um " $\mathrm{X}$ " na categoria apropriada.

- Coletar o questionário completo antes da visita clínica. Antes de finalizar, revisar o questionário para verificar questões em branco. Se o participante esqueceu alguma questão, indique e solicite a ele/ela que complete a mesma.

SECÃO CLÍNICA

AS QUESTÕES DE 1 A 7 DEVEM SER COMPLETADAS PELO INVESTIGADOR:

COMPLETAR AS QUESTÕES 1 E 2 COM A AJUDA DOS PAIS/CUIDADORES OU RESPONSÁVEIS ANTES DE FORNECER O QUESTIONÁRIO DE QUALIDADE DE VIDA

1. Nos últimos 12 meses, alguns dos eventos abaixo ocorreram?

a. Os pais perderam o emprego:

b. Algum membro da família deixou a casa:

c. Perdeu moradia ou teve que mudar:

d. Perda de benefícios (direitos): vale alimentação, auxílio desemprego.

e. Perda de seguro saúde:

f. Algum membro da família esteve hospitalizado:

g. Algum membro da família esteve muito doente:

h. Mudança do cuidador (responsável):

i. Separação dos pais:

j. Divórcio dos pais:

k. Detenção/Prisão dos pais:

1. Casamento dos pais:

m. Nascimento de irmão:

n. Mãe começou a trabalhar:

o. Início na escola ou mudou para uma nova escola:

p. Mudança na condição financeira dos pais:

q. Perda de amigo íntimo (da criança):

r. Morte na família:

Se houve morte na família, quem morreu?

1-mãe 2-pai

3-irmão/irmã ou filhos de outros casamentos dos pais (sem vínculo biológico)

4-avós 9-outro membro da família 
2. A criança é infectada pelo HIV?

a. A criança sabe que ela é infectada?

SE SIM, complete 'a1'.

a1. Com qual idade a criança soube pela primeira vez da sua situação de infectada: (colocar 1 se desconhecido)

b. A criança está na escola?

c. A escola sabe do diagnóstico?

RESPONDER OS SEGUINTES ITENS DEPOIS QUE OS PAIS/CUIDADORES OU RESPONSÁVEIS TENHAM TERMINADO O QUESTIONÁRIO OU DEPOIS QUE VOCÊ TENHA CERTEZA DE QUE ISSO NÃO SERÁ POSSÍVEL:

5. Como o questionário foi preenchido?

Se responder '4', completar 'a' e PARAR.

1- auto-respondido pelos pais/cuidadores ou responsáveis

2- entrevista face a face feita pelo entrevistador

3- entrevista por telefone

4- não completado

9- outro, especificar

Se Outro, especificar:[30]

a. Se respondeu ' 4 ' - Não completado, indicar a razão:

2 - paciente não compareceu à consulta

3 - não houve tempo suficiente para entrevista

9 - outra razão

Se Outra razão, especifique:[30]

6. Quem respondeu as questões?

1 - mãe biológica

2 - pai biológico

3 - outro parente

4 - pais adotivos

5 - pais substitutos

9 - outra pessoa

Se outra pessoa ou outro parente, especifique:[30]

7. Em que língua o questionário foi administrado?

Se outro, especifique:[30]

$$
\begin{aligned}
& 1 \text { - inglês } \\
& 2 \text { - espanhol } \\
& 3 \text { - francês } \\
& 4 \text { - creole } \\
& 5 \text { - português } \\
& 9 \text { - outro }
\end{aligned}
$$
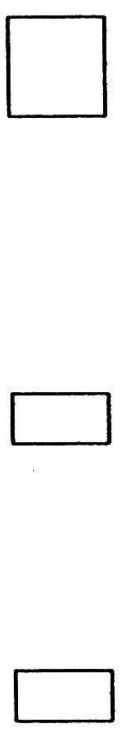

Qual o idioma que é falado em casa?

1 - inglês

2 - espanhol

3 - francês

4 - creole

5 - português

9- Outro

Se outro, especifique:[30] 
Número do paciente Código da Instituição

\section{INSTRUCÕES AOS PAIS/CUIDADORES OU RESPONSÁVEIS:}

Por favor, responda as questões circulando a melhor resposta. Não há questões certas ou erradas. Se você não entender o que significa determinada questão, não hesite em perguntar ao investigador. Por favor, responda da melhor maneira possível todas as questões.

I. Avaliação Geral da Saúde. Essas questões referem-se à saúde e comportamento de sua criança.

A. Em uma escala de 1 a 10: (sendo o 1 para muito ruim/pior e o 10 muito bom/ótimo) COMO SUA CRIANÇA TEM SE SENTIDO, EM MÉDIA, NOS ÚLTIMOS 3 MESES?

(Por favor, circule um número para cada questão)

pior do que ele/ela já se sentiu

1. De maneira geral?

\begin{tabular}{llllllllll}
1 & 2 & 3 & 4 & 5 & 6 & 7 & 8 & 9 & 10 \\
\hline
\end{tabular}

2. Fisicamente?

\begin{tabular}{llllllllll}
1 & 2 & 3 & 4 & 5 & 6 & 7 & 8 & 9 & 10 \\
\hline
\end{tabular}

3. Emocionalmente?

\begin{tabular}{llllllllll}
1 & 2 & 3 & 4 & 5 & 6 & 7 & 8 & 9 & 10 \\
\hline
\end{tabular}

4. Acerca de sua atividade em sala de aula?

\begin{tabular}{llllllllll}
1 & 2 & 3 & 4 & 5 & 6 & 7 & 8 & 9 & 10 \\
\hline
\end{tabular}

B. Ao ler as questões abaixo, decida qual frase melhor descreverá como esteve a saúde da sua criança ao longo dos últimos 3 meses, então circule o número que melhor combina com a resposta que você escolher.

DURANTE OS ÚLTIMOS 3 MESES... (Por favor, circule um número para cada questão)

1. A saúde da minha criança é excelente:

2. Minha criança parece resistir a doença muito bem:

$\begin{array}{ccc}\begin{array}{c}\text { Nunca ou } \\ \text { raramente }\end{array} & \begin{array}{c}\text { Durante } \\ \text { algum } \\ \text { tempo }\end{array} & \begin{array}{c}\text { Quase } \\ \text { sempre } \\ \text { ou } \\ \text { sempre }\end{array} \\ & & \end{array}$

3. Minha criança parece menos sadia do que as outras crianças que eu conheço:

4. Minha criança é bastante suscetível a doenças que estão circulando:

5. Minha criança é pouco desajeitada:

\begin{tabular}{ccc} 
& & sempre \\
\hline 1 & 2 & 3 \\
1 & 2 & 3
\end{tabular}

6. Minha criança parece ter uma tendência a sofrer acidentes:

7. Quando minha criança está doente ou machucada,

ela geralmente se recupera rapidamente:

1

1

1

1

1
2

2

2

2

2 


\section{A valiação do estado físico}

A. O quanto, se isso acontece, A SAÚDE DA SUA CRIANCCA tem interferido com as suas atividades durante as ÚLTIMAS 4 SEMANAS.

(Por favor, circule um número para cada questão)

\section{O QUANTO A SAÚDE DE SUA CRIANÇA INTERFERIU COM...}

nada/nem

um pouco

um pouco moderada- muito demais mente (mais

ou menos)

1. o tipo ou quantidade de atividades vigorosas como levantar objetos pesados, correr ou participar de esportes extenuantes?

2. o tipo ou quantidade de 1 2 3 4 5 atividades moderadas, como arrastar uma mesa, carregar pacotes ou esportes como boliche?

3. caminhar, subir rampa ou subir alguns lances de escadas?

4. caminhar uma quadra?

5. agachar, curvar, levantar?

6. comer, se vestir, tomar banho ou ir ao banheiro?
1

2

3

4

5

1

2

3

4

5

12

3

4

5

1

2

3

4

5

B. Por favor, comente sobre quaisquer outros problemas, se assim desejar[70]: 


\section{Avaliação da saúde psicológica}

As afirmações abaixo são sobre os problemas comportamentais que as crianças podem ter. Assim que você ler cada sentença, decida qual frase melhor descreve o comportamento de sua criança nos últimos 3 meses, então circule o número que se corresponde a sua resposta.

Pense sobre sua criança, DURANTE OS 3 ÚLTIMOS MESES...

(Por favor, circule um número para cada questão)

1. Minha criança tem mudanças súbitas de humor ou sentimentos.

\begin{tabular}{cc}
$\begin{array}{c}\text { Muitas } \\
\text { vezes }\end{array}$ & $\begin{array}{c}\text { Algumas } \\
\text { vezes }\end{array}$ \\
\hline
\end{tabular}

2. Minha criança sente ou reclama que ninguém a ama

12

3. Minha criança é muito tensa ou nervosa....................

12

4. Minha criança engana ou conta mentiras.

\section{1}

2

5. Minha criança é medrosa ou ansiosa.

1

2

6. Minha criança argumenta demais.

7. Minha criança tem dificuldade de se concentrar, não presta atenção por muito tempo

8. Minha criança se confunde facilmente, parece estar um pouco fora do ar ou no mundo da lua

9. Minha criança é intimidadora ou é cruel ou com os outros.

.....................................

10. Minha criança é desobediente em casa.

1

11. Minha criança é desobediente na escola.

12. Minha criança não fica arrependida depois de se comportar mal

13. Minha criança tem problemas em se relacionar com outras crianças. 


\section{Avaliação da saúde psicológica (continuação)}

Pense sobre sua criança DURANTE OS ÚLTIMOS 3 MESES...

(Por favor, circule um número para cada questão)

14. Minha criança tem problemas de se relacionar com os professores.

\begin{tabular}{cc}
$\begin{array}{c}\text { Muitas } \\
\text { vezes }\end{array}$ & $\begin{array}{c}\text { Algumas } \\
\text { vezes }\end{array}$ \\
\hline
\end{tabular}

15. Minha criança é impulsiva, age sem pensar

12

1

2

3

16. Minha criança sente-se inútil, sem valor ou inferior.

17. Minha criança não é querida pelas outras crianças 1 3

18. Minha criança tem muita dificuldade em tirar certas idéias da cabeça (tem obsessões). 1 3

19. Minha criança é irrequieta ou superativa, não consegue ficar sentada..

20. Minha criança é teimosa, emburrada, irritadiça..... ... 1

$2 \quad 3$

21. Minha criança tem o temperamento muito forte e perde a paciência facilmente. 12

22. Minha criança é infeliz, triste ou deprimida............. 1 2

23. Minha criança é fechada, não se envolve com as outras

24. Minha criança quebra coisas de propósito, destrói deliberadamente suas coisas ou as coisas de outras pessoas. $1 \quad 2$

25. Minha criança fica muito apegada aos adultos........ 1 2

26. Minha criança chora demais 1

27. Minha criança solicita muita atenção. 1

28. Minha criança é muito dependente dos outros......... 1 2 3 
IV. Avaliação das atividades pessoais e sociais (Assinalar com " $X$ " na linha próxima de sua resposta)

\section{A. DURANTE AS 4 ÚLTIMAS SEMANAS, QUANTOS DIAS...}

1. A sua criança ficou na cama (a maioria do tempo ou durante todo o dia) devido a alguma doença ou lesão/ferimento/acidente/machucado?

\begin{tabular}{|l|l|l|l|l|l|}
\hline 0 & $1-2$ & $3-5$ & $6-10$ & $11-15$ & \\
$(1)$ & $(3)$ & 16 & $\overline{(6)}$ \\
\hline
\end{tabular}

2. A doença ou lesão manteve sua criança fora da escola/creche? (se este período for de férias escolares, diga em relação ao último mês em que a escola/creche estava aberta)

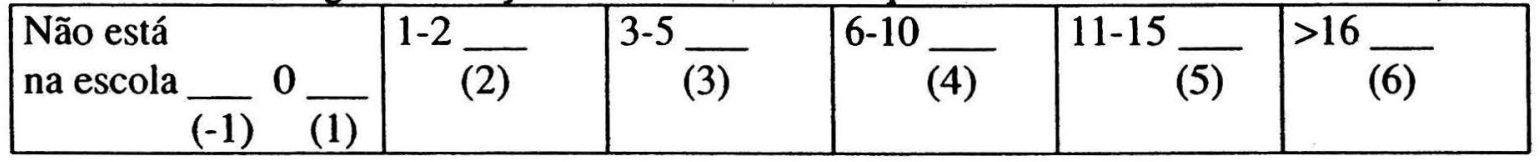

B. Por favor, assinale somente uma resposta para cada questão:

1. Qual o atual grau de escolaridade do seu filho?

Berçário/maternal/Pré-escola............................ 11

Jardim da infância........................................... 12

$1^{2}$ série...................................................... 13

$2^{\mathrm{a}}$ série........................................................ 14

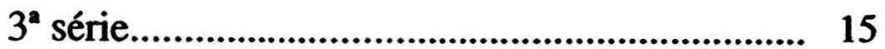

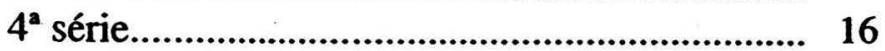

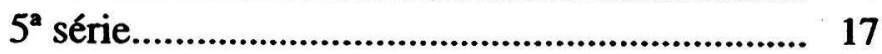

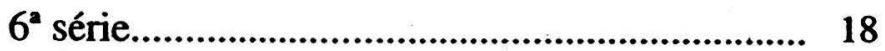

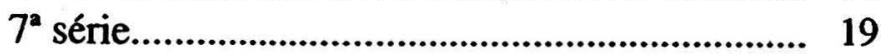

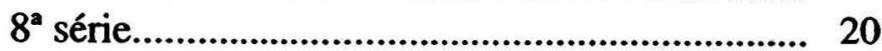

Não está na escola........................................... 99

2. Sua criança repetiu alguma série?..................................................... sim não

3. No geral, sua criança teve a freqüência na escola comprometida devido à sua condição de saúde?

4. No geral sua criança esteve limitada no tipo ou na quantidade de outras atividades devido à sua saúde?

$\operatorname{sim}$ não

5. No geral, sua criança participa das atividades esportivas na escola?. $\operatorname{sim}^{1}$ não

6. Sua criança freqüenta classe especial ou necessita de ajuda especial na escola devido a incapacidade ou problema de saúde? $\operatorname{sim}$ não

Se sim, completar 'a', a seguir:

a. Que tipo de ajuda especial sua criança recebe?

11- Leitura

(assinale uma)

12- Dificuldade no aprendizado.

13- Fala e linguagem.

14- Fisioterapia/Terapia Ocupacional

15- Mais do que um dos acima.

99- Outra.

Se outra, especificar:[30] 
IV. Utilização de serviços de saúde (Assinalar com "X" na linha próxima de sua resposta)

\section{A. DURANTE AS ÚLTIMAS 4 SEMANAS...}

1. QUANTAS NOITES sua criança ficou no hospital?

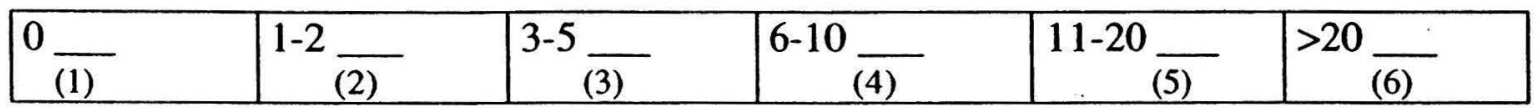

2. QUANTAS VISITAS sua criança fez ao ambulatório ou pronto-socorro para ver o médico, enfermeiro ou outro especialista?

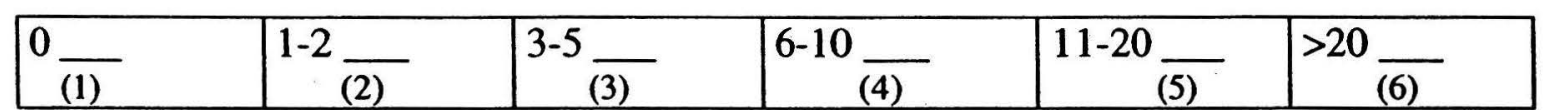

3. QUANTAS VEZES a sua criança recebeu visita de um enfermeiro ou outro profissional de saúde em sua casa?

\begin{tabular}{|c|c|c|c|c|c|}
\hline $0^{0} \overline{(1)}$ & $1-2 \frac{}{(2)}$ & $3-5 \frac{}{(3)}$ & $6-10 \frac{}{(4)}$ & $11-20 \frac{}{(5)}$ & $>20 \frac{}{(6)}$ \\
\hline
\end{tabular}

4. QUANTAS VEZES você telefonou para uma clínica, médico, enfermeiro, ou outro profissional do serviço de saúde para uma consulta através do telefone acerca de sua criança?

\begin{tabular}{|c|c|c|c|c|c|}
\hline $0_{\overline{(1)}}$ & $1-2$ & $3-5$ & 6-10 & $11-20$ & $>20$ \\
\hline
\end{tabular}


B. Por favor, assinale somente uma alternativa para cada questão:

DURANTE AS ÚLTIMAS 4 SEMANAS, a sua criança apresentou

(assinale uma)

alguma doença ou lesão que necessitou receber algum medicamento, exceto vitaminas, receitado pelo médico? $\operatorname{sim}_{1}$ não 2

SE NÃO, vá para a parte "C".

SE SIM, que tipo de medicação sua criança tomou?

1. medicamento para a dor? $\operatorname{sim}_{1}$ não 2

2. antibióticos?. $\operatorname{sim}{ }_{1}$ não 2

3. medicamentos para resfriado? sim não

4. medicamentos para chiado no peito? $\operatorname{sim}$ não

5. cremes, pomadas para lesões, feridas? $\operatorname{sim}$ não

6. medicamentos contra diarréia? 12 $\operatorname{sim}$ não

C. A seguir há uma lista de tratamentos alternativos que você pode estar dando para a sua criança. Esses tratamentos são outros do que os medicamentos tradicionais. Desde a última consulta, a sua criança recebeu ou tomou algum dos seguintes?
a. ervas medicinais?
sim não
Quais?
$1 \quad 2$
b. vitaminas?
sim não
Quais?
12
c. acupuntura?
$\operatorname{sim}$ não
d. ioga?
sim não
e. aromaterapia?
sim não
f. foi a algum centro espírita ou outro tipo de centro para receber passes?
Qual?
$\operatorname{sim}$ não
g. utilizou algum tipo de cuidado por curandeiro, benzedeira e outros?
$\operatorname{sim}$ não
Qual?
1 nao 2
h. tratamento com massagens?
$\operatorname{sim}$ não
i. homeopatia?
$\operatorname{sim}_{1}$ não
j. outros:
sim não 


\section{Sintomas ou sinais}

As questões a seguir perguntam acerca de SINTOMAS OU SINAIS que sua criança possa ter tido durante as últimas 4 semanas. Por favor, responda $O$ QUANTO DE DESCONFORTO os seguintes sinais ou sintomas causaram em sua criança DURANTE AS ÚLTIMAS 4 SEMANAS.

QUANTO DE DESCONFORTO A SUA CRIANÇA SENTIU COM ESSES SINTOMAS OU SINAIS?

(Por favor circule somente uma resposta para cada questão)

$\begin{array}{cccc}\begin{array}{c}\text { Nem um } \\ \text { pouco }\end{array} & \text { Muito pouco Pouco } & \begin{array}{c}\text { Moderada Muito Demais } \\ \text { mente } \\ \text { (mais ou } \\ \text { menos) }\end{array}\end{array}$

1. dor física ou no corpo todo?.

2. chiado, tosse?

$\begin{array}{llllll}1 & 2 & 3 & 4 & 5 & 6 \\ 1 & 2 & 3 & 4 & 5 & 6\end{array}$

3. náuseas, vômitos, dor abdominal, dor de estômago?...........................

5. manchas, coceiras ou outros problemas de pele?

6. fadiga, cansaço,

\begin{tabular}{lllllll} 
fraqueza?.......................... & 1 & 2 & 3 & 4 & 5 & 6 \\
\hline 7. tontura, delírio febril? & 1 & 2 & 3 & 4 & 5 & 6
\end{tabular}

8. febre, suores noturnos, tremores e calafrios?

9. perda de apetite?

10. problemas de sono?.....

11. problemas nos olhos ou para enxergar?

12. dor de cabeça?

?................

1
1
1

\begin{tabular}{lllll}
2 & 3 & 4 & 5 & 6 \\
2 & 3 & 4 & 5 & 6 \\
\hline 2 & 3 & 4 & 5 & 6
\end{tabular}

13. boca seca ou dolorida, problemas para engolir?....

14. dor ou aperto no peito?

15. dificuldade para

respirar ou pegar o ar?.......

1

\begin{tabular}{lllll}
2 & 3 & 4 & 5 & 6 \\
2 & 3 & 4 & 5 & 6 \\
\hline
\end{tabular}

16. nariz escorrendo ou problemas de sinusite?.......

17. dor no músculo, nas articulações (juntas) ou nos ossos?.

18. dor, formigamento, dormência, paralisia nas mãos ou pés?.......................

19. dor de ouvido?

$\begin{array}{lll}1 & 2 \\ 1 & 2\end{array}$

$\begin{array}{ll}2 & 3 \\ 2 & 3\end{array}$

6

$\begin{array}{ll}1 & 2 \\ 1 & 2\end{array}$

3
3

$\begin{array}{lll}4 & 5 & 6 \\ 4 & 5 & 6\end{array}$

20. desconforto ou mal estar geral?

3

4

$5 \quad 6$

$\begin{array}{llllll}1 & 2 & 3 & 4 & 5 & 6\end{array}$

$$
1
$$

2

3

4

5

6

O seu esforço será muito valioso para auxiliar na condução do tratamento de nossas crianças. 
Anexo 5: Questionário de avaliação da qualidade de vida

12 a 20 anos 


\section{AVALIAÇÃO DA QUALIDADE DE VIDA - REVISADO \\ (Para idades de 12 a 20 anos) \\ QL4005(000)/00-00-00}

NIAID AIDS CLINICAL TRIALS GROUP

Número do paciente

Código da Instituição

Data da entrevista

Página 1 de 11

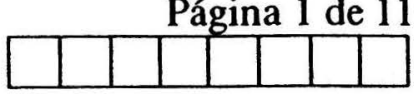

\section{INSTRUCÕES PARA O ENTREVISTADOR:}

- O seguinte questionário deve ser dado para os pais/cuidadores ou responsáveis antes da visita clínica e preferencialmente em uma área reservada e quieta (i.e. sala de exame ou outra sala). Os pais/cuidadores ou responsáveis precisam ser capazes de ler e devem ter a $4^{2}$ série do ensino fundamental, para completar o questionário por si mesmos. Se isso não acontecer, o investigador deverá completar o questionário com o indivíduo. Este questionário deverá ser dado para os pais/cuidadores ou responsáveis que têm crianças com idades entre 12 e 20 anos.

- As questões de 1 a 7 da seção clínica devem ser completadas pelo investigador. As páginas 3-11 devem ser completadas pelos pais/responsáveis. Antes de dar o questionário para os pais/responsáveis, por favor, preencha o cabeçalho e destaque as páginas 1-2.

- É muito importante que o pesquisador esteja familiarizado com o conteúdo e formato do questionário antes de entregá-lo aos participantes do estudo. Na primeira visita para esse estudo, recomenda-se iniciar com a explicação aos pais/responsáveis acerca do formato das questões e como devem ser completadas.

- Cada questão tem o mesmo formato geral e contém vários itens. Observe que os respondentes sempre deverão CIRCULAR um número ou marcar um " $X$ " na categoria apropriada.

- Coletar o questionário completo antes da visita clínica. Antes de finalizar, revisar o questionário para verificar questões em branco. Se o participante esqueceu alguma questão, indique e solicite a ele/ela que complete a mesma.

\section{SECÃO CLÍNICA}

\section{AS QUESTŌES DE 1 A 7 DEVEM SER COMPLETADAS PELO INVESTIGADOR:} COMPLETAR AS QUESTÕES 1 E 2 COM A AJUDA DOS PAIS/CUIDADORES OU RESPONSÁVEIS ANTES DE FORNECER O QUESTIONÁRIO DE QUALIDADE DE VIDA

1. Nos últimos 12 meses, alguns dos eventos abaixo ocorreram?

a. Os pais perderam o emprego:

b. Algum membro da família deixou a casa:

c. Perdeu moradia ou teve que mudar:

d. Perda de benefícios (direitos): vale alimentação, auxílio desemprego

e. Perda de seguro saúde:

f. Algum membro da família esteve hospitalizado:

g. Algum membro da família esteve muito doente:

h. Mudança do cuiador (responsável):

i. Separação dos pais:

j. Divórcio dos pais:

k. Detenção/Prisão dos pais:

1. Casamento dos pais:

m. Nascimento de irmão

n. Mãe começou a trabalhar:

o. Início na escola ou mudou para uma nova escola:

p. Mudança na condição financeira dos pais:

q. Perda de amigo íntimo (da criança):

r. Morte na família:

Se houve morte na família, quem morreu?

1-mãe 2-pai

3-irmão/irmã ou filhos de outros casamentos dos pais (sem vínculo biológico)

4-avós

9-outro membro da família 
2. A criança é infectada pelo HIV?

a. A criança sabe que ela é infectada?.

SE SIM, complete 'a1'.

a1. Com qual idade a criança soube pela primeira vez da sua situação de infectada: (colocar 1 se desconhecido).

b. A criança está na escola?

c. A escola sabe do diagnóstico?.

RESPONDER OS SEGUINTES ITENS DEPOIS QUE OS PAIS/CUIDADORES OU RESPONSÁVEIS TENHAM TERMINADO O QUESTIONÁRIO OU DEPOIS QUE VOCÊ TENHA CERTEZA DE QUE ISSO NÃO SERÁ POSSÍVEL:

5. Como o questionário foi preenchido?

Se responder '4', completar 'a' e PARAR.

1- auto-respondido pelos pais/cuidadores ou responsáveis

2- entrevista face a face feita pelo entrevistador

3- entrevista por telefone

4- não completado

9- outro, especificar

Se Outro, especificar: [30]

a. Se respondeu ' 4 ' - Não completado, indicar a razão:

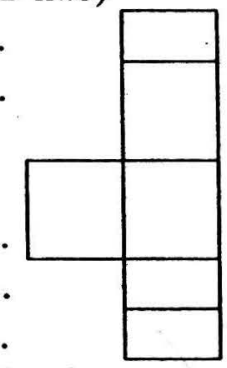

1 - recusa

$$
\begin{aligned}
& 2 \text { - paciente não compareceu à consulta } \\
& 3 \text { - não houve tempo suficiente para entrevista } \\
& 9 \text { - outra razão }
\end{aligned}
$$

Se Outra razão, especifique:[30]

6. Quem respondeu as questões?

Se a pessoa se enquadrar nos itens 6 e 7 somente completar a seção IV, questões A1 e A2;

B1,2,5,6,7; seção V, questões B1-6 e C; e seção VI, questões 1 a 20.

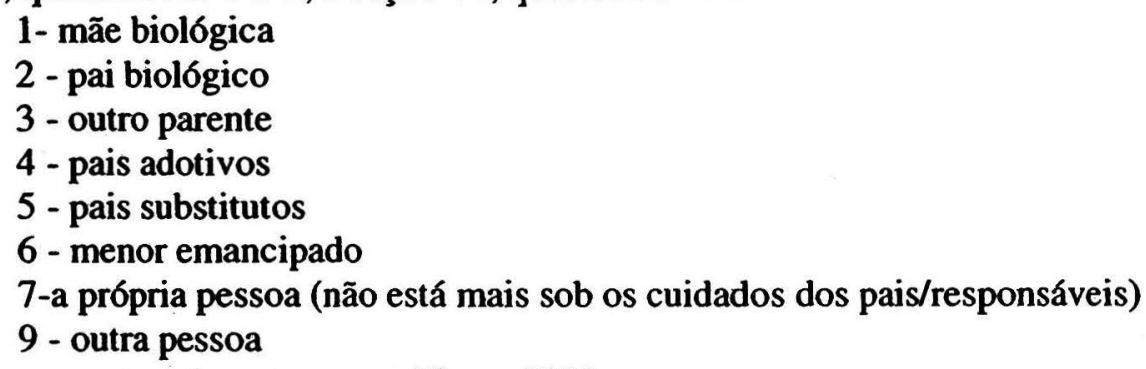

Se outra pessoa ou outro parente, especifique:[30]

7. Em que língua o questionário foi administrado?

Se outro, especifique:[30]

$$
\begin{aligned}
& 1 \text { - inglês } \\
& 2 \text { - espanhol } \\
& 3 \text { - francês } \\
& 4 \text { - creole } \\
& 5 \text { - português } \\
& 9 \text { - outro }
\end{aligned}
$$

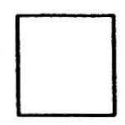

a. Qual o idioma que é falado em casa?

$$
\begin{aligned}
& 1 \text {-inglês } \\
& 2 \text { - espanhol } \\
& 3 \text { - francês } \\
& 4 \text { - creole } \\
& 5 \text { - português } \\
& 9 \text { - Outro }
\end{aligned}
$$

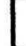

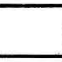




\section{AVALIAÇÃO DA QUALIDADE DE VIDA - REVISADO \\ (Para idades de12 a 20 anos) \\ QL4004(000)/00-00-00}

NIAID AIDS CLINICAL TRIALS GROUP

Número do paciente

Código da Instituição

Data da entrevista

Página 3 de 11

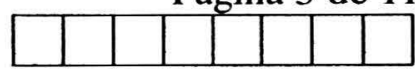

\section{INSTRUCÕES AOS PAIS/CUIDADORES OU RESPONSÁVEIS:}

Por favor responda as questões circulando a melhor resposta. Não há questões certas ou erradas. Se você não entender o que significa determinada questão, não hesite em perguntar ao investigador. Por favor, responda da melhor maneira possível todas as questões.

I. Avaliação Geral da Saúde. Essas questões referem-se à saúde e comportamento de sua criança.

A. Em uma escala de 1 a 10: (sendo o 1 para muito ruim/pior e o 10 muito bom/ótimo) COMO SUA CRIANÇA TEM SE SENTIDO, EM MÉDIA, NOS ÚLTIMOS 3 MESES?

(Por favor, circule um número para cada questão)

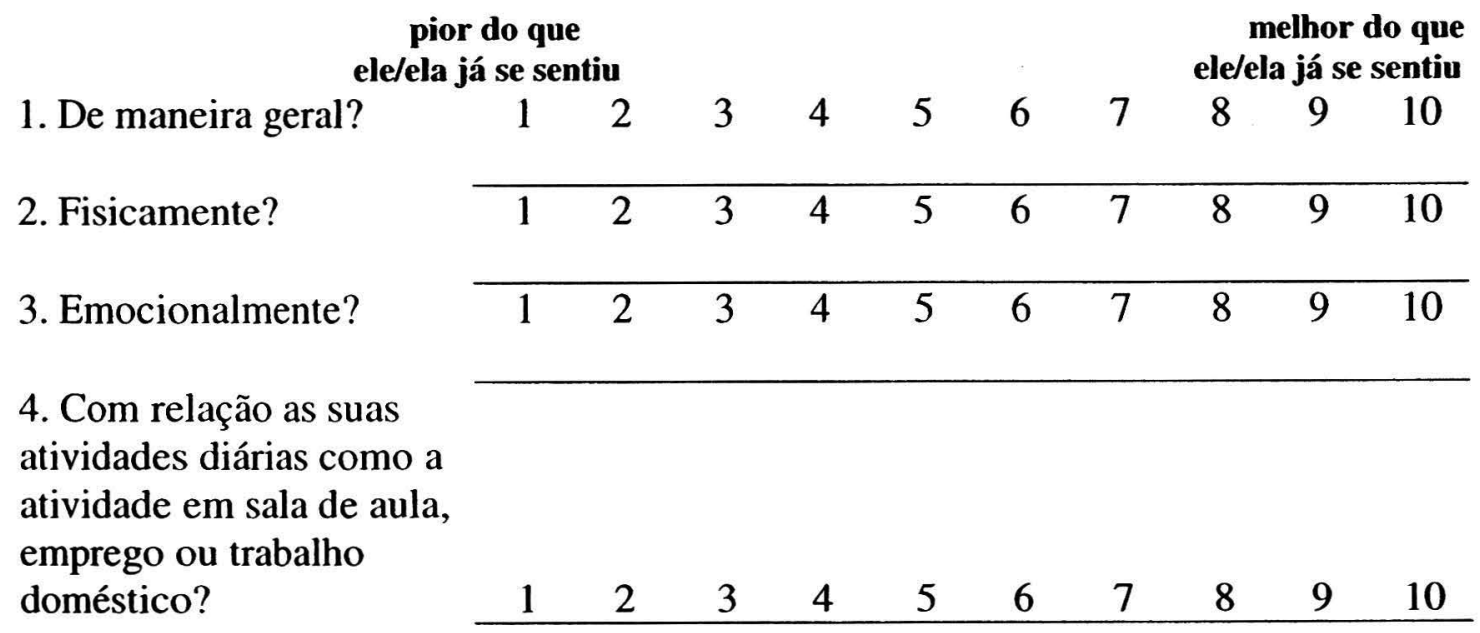


A. O quanto, se isso acontece, A SAÚDE DA SUA CRIANÇA tem interferido com as suas atividades durante as ÚLTIMAS 4 SEMANAS.

(Por favor, circule um número para cada questão)

\begin{tabular}{l}
$\begin{array}{l}\text { O QUANTO A SAÚDE DE SUA } \\
\text { CRIANÇA INTERFERIU COM... }\end{array}$ um pouco \\
\cline { 3 - 5 } pouco
\end{tabular}

3. caminhar, subir rampa ou subir alguns andares de escadas?

$\begin{array}{lllll}1 & 2 & 3 & 4 & 5\end{array}$

4. caminhar uma quadra? 1 2 3 4

5. agachar, curvar, levantar? 1 2

3

4

6. comer, se vestir, tomar banho ou 1

2

3

4

5 ir ao banheiro

B. Por favor comente sobre quaisquer outros problemas, se assim desejar:[70] 


\section{Avaliação da saúde psicológica}

As afirmações abaixo são sobre os problemas comportamentais que as crianças podem ter. Assim que você ler cada sentença, decida qual frase melhor descreve o comportamento de sua criança nos últimos 3 meses, então circule o número que se corresponde a sua resposta.

Pense sobre sua criança, DURANTE OS 3 ÚLTIMOS MESES...

(Por favor, circule um número para cada questão)

\begin{tabular}{|c|c|c|c|}
\hline \multicolumn{4}{|c|}{ (Por favor, circule um número para cada questão) } \\
\hline & $\begin{array}{c}\text { Muitas } \\
\text { vezes }\end{array}$ & $\begin{array}{l}\text { Algumas } \\
\text { vezes }\end{array}$ & Nunca \\
\hline 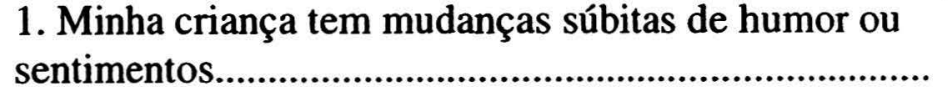 & 1 & 2 & 3 \\
\hline 2. Minha criança sente ou reclama que ninguém a ama & 1 & 2 & 3 \\
\hline 3. Minha criança é muito tensa ou nervosa....................... & 1 & 2 & 3 \\
\hline 4. Minha criança engana ou conta mentiras................... & 1 & 2 & 3 \\
\hline 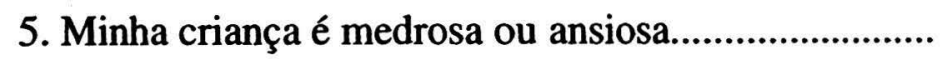 & 1 & 2 & 3 \\
\hline 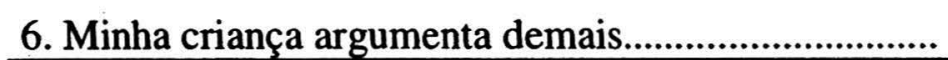 & 1 & 2 & 3 \\
\hline
\end{tabular}

7. Minha criança tem dificuldade de se concentrar, não presta atenção por muito tempo

8. Minha criança se confunde facilmente, parece estar um pouco fora do ar ou no mundo da lua.

9. Minha criança é intimidadora ou é cruel com os outros

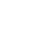

10. Minha criança é desobediente em casa.....................

11. Minha criança é desobediente na escola.

1

2

3

12. Minha criança não fica arrependida depois de se comportar mal.

13. Minha criança tem problemas em se relacionar com outras crianças 
III. Avaliação da saúde psicológica (continuação)

Pense sobre sua criança DURANTE OS ÚLTIMOS 3 MESES...

(Por favor, circule um número para cada questão)

Muitas Algumas Nunca

vezes vezes

14. Minha criança tem problemas de se relacionar com os professores.

$1 \quad 2 \quad 3$

15. Minha criança é impulsiva, age sem pensar

1

2

3

16. Minha criança sente-se inútil, sem valor ou inferior.

17. Minha criança não é querida pelas outras crianças

1

2

3

18. Minha criança tem muita dificuldade em tirar certas idéias da cabeça (tem obsessões).

19. Minha criança é irrequieta ou superativa, não consegue ficar sentada.

20. Minha criança é teimosa, emburrada, irritadiça ... 1 2 3

21. Minha criança tem o temperamento muito forte $e$ perde a paciência facilmente

22. Minha criança é infeliz, triste ou deprimida............

1

2

23. Minha criança é fechada, não se envolve com as outras. 1 2

24. Minha criança se sente perseguida o tempo todo pelos outros

25. Minha criança procura ficar com jovens que estão sempre com problemas disciplinares (suspensão, prisão)

26. Minha criança mantém suas coisas para si mesma 1 2

27. Minha criança preocupa-se muito

$\begin{array}{lll}1 & 2 & 3 \\ 1 & 2 & 3\end{array}$

28. Minha criança é muito dependente dos outros........ 


\section{Avaliação das atividades pessoais e sociais}

\section{A. DURANTE AS 4 ÚLTIMAS SEMANAS, QUANTOS DIAS...}

(Assinalar com " $\mathrm{X}$ " na linha próxima de sua resposta)

1. A sua criança ficou na cama (a maioria do tempo ou durante todo o dia) devido a alguma doença ou lesão/ferimento/acidente/machucado?

\begin{tabular}{|l|l|l|l|l|l|}
\hline 0 & $1-2$ & $3-5$ & $6-10$ & $11-15$ & \\
$(1)$ & $(3)$ & 16 & $\frac{(6)}{(5)}$ \\
\hline
\end{tabular}

2. A doença ou lesão manteve sua criança fora da escola? (se este período for de férias escolares, diga em relação ao último mês em que a escola estava aberta)

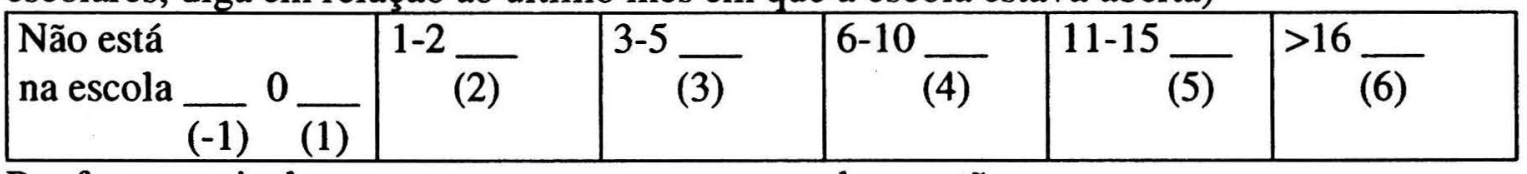

B. Por favor, assinale somente uma resposta para cada questão:

1. Qual o atual grau de escolaridade do seu filho?

(assinale uma)

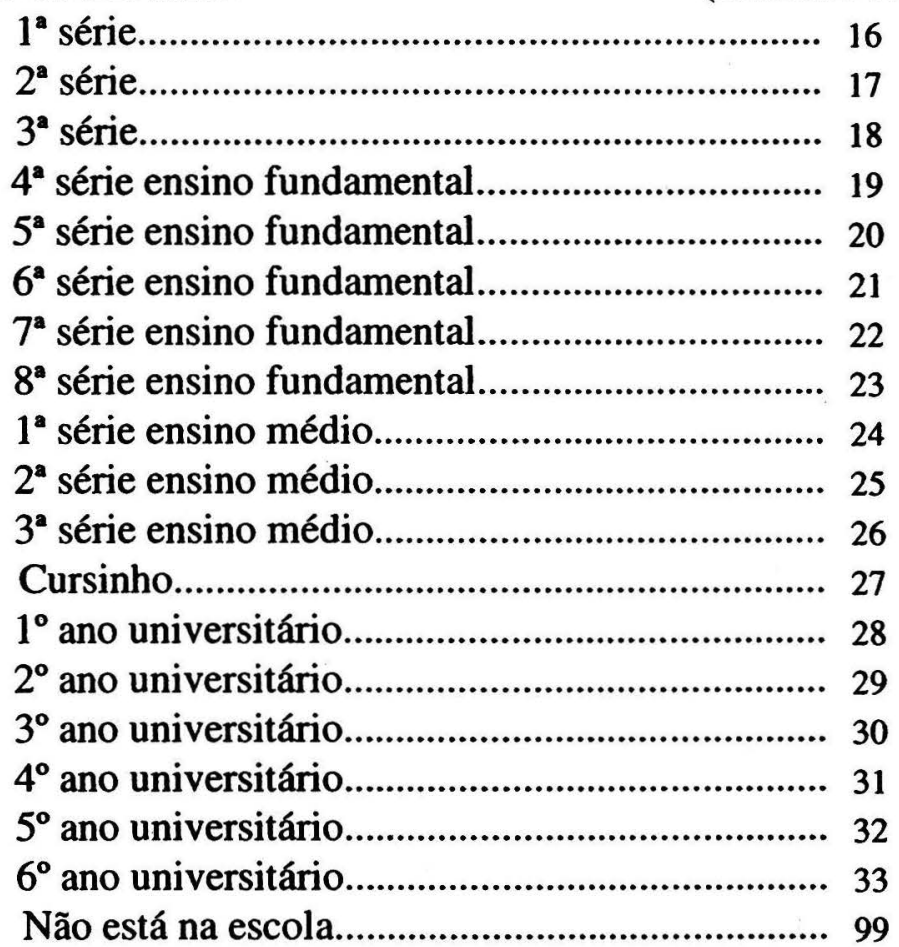

2. Sua criança repetiu alguma série?

$\operatorname{sim}{ }_{1}$ não $_{2}$

3. No geral, sua criança teve a freqüência na escola comprometida devido à sua condição de saúde?

$\operatorname{sim}$ não

4. No geral sua criança esteve limitada no tipo ou na quantidade de outras atividades devido à sua saúde?

$\operatorname{sim}$ não

5. No geral, sua criança participa das atividades esportivas na escola?

$\operatorname{sim}$ não

6. Sua criança freqüenta classe especial ou necessita de ajuda especial na escola devido a incapacidade ou problema de saúde?. sim

não 
Se sim, completar ' $a$ ', a seguir:

a. Que tipo de ajuda especial sua criança recebe?

(assinale uma)

11 - Leitura.

12- Dificuldade no aprendizado.

13- Fala e linguagem.

14- Fisioterapia/Terapia Ocupacional.

15- Mais do que um dos acima.

99- Outra.

Se outra, especificar:[30] 
IV. Utilização de serviços de saúde (Assinalar com "X" na linha próxima de sua resposta)

A. DURANTE AS ÚlTIMAS 4 SEMANAS...

1. QUANTAS NOITES sua criança ficou no hospital?

\begin{tabular}{|l|l|l|l|l|l|}
\hline 0 & $1-2$ & $3-5$ & $6-10$ & $11-20$ & \\
$(1)$ & $(3)$ & 20 & $\frac{(6)}{(4)}$ \\
\hline
\end{tabular}

2. QUANTAS VISITAS sua criança fez ao ambulatório ou pronto-socorro para ver o médico, enfermeiro ou outro especialista?

\begin{tabular}{|l|l|l|l|l|l|}
\hline 0 & $1-2$ & $3-5$ & $6-10$ & $11-20 \frac{}{(2)}$ & $>20$ \\
\hline
\end{tabular}

3. QUANTAS VEZES a sua criança recebeu visita de um enfermeiro ou outro profissional de saúde em sua casa?

\begin{tabular}{|l|l|l|l|l|l|}
\hline 0 & $1-2$ & $3-5$ & $6-10$ & $11-20$ & \\
\hline$(1)$ & $1(3)$ & 20 & $\frac{(6)}{(5)}$ \\
\hline
\end{tabular}

4. QUANTAS VEZES você telefonou para uma clínica, médico, enfermeiro, ou outro profissional do serviço de saúde para uma consulta através do telefone acerca de sua criança?

\begin{tabular}{|l|l|l|l|l|l|}
\hline 0 & $1-2$ & $3-5$ & $6-10$ & $11-20$ & \\
$(1)$ & $(3)$ & 20 & $\frac{(6)}{(3)}$ \\
\hline
\end{tabular}


B. Por favor, assinale somente uma alternativa para cada questão:

DURANTE AS ÚLTIMAS 4 SEMANAS, a sua criança apresentou

(assinale uma)

alguma doença ou lesão que necessitou receber algum medicamento,

exceto vitaminas, receitado pelo médico? $\operatorname{sim}_{1}$ não

SE NÃO, vá para a parte "C".

SE SIM, qual das seguintes prescrições de medicamentos sua criança usou?

1. medicamento para a dor?

\begin{tabular}{|c|c|}
\hline $\operatorname{sim}$ & não \\
\hline 1 & 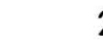 \\
\hline $\operatorname{sim}$ & não \\
\hline 1 & 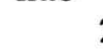 \\
\hline $\operatorname{sim}$ & não \\
\hline 1 & 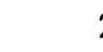 \\
\hline $\operatorname{sim}$ & não \\
\hline 1 & 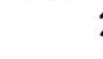 \\
\hline sim & não \\
\hline 1 & 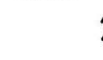 \\
\hline $\operatorname{sim}$ & não \\
\hline
\end{tabular}

2. antibióticos?

3. medicamentos para resfriado?

4. medicamentos para chiado no peito?

5. cremes, pomadas para lesões, feridas?

C. A seguir há uma lista de tratamentos alternativos que você pode estar dando para a sua
criança. Esses tratamentos são outros do que os medicamentos tradicionais. Desde a última consulta, a sua criança recebeu ou tomou algum dos seguintes?
a. ervas medicinais?
$\operatorname{sim}_{1}$ não 2
Quais?

$\operatorname{sim}_{1}$ não $_{2}$
Quais?
$\operatorname{sim}$ não
c. acupuntura?.
$\operatorname{sim}^{1}$ não
d. ioga?

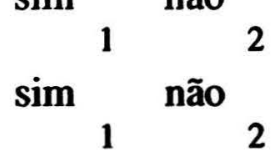
f. foi a algum centro espírita ou outro tipo de centro para receber passes?
$\operatorname{sim} 1$ não
Qual?
g. utilizou algum tipo de cuidado por curandeiro, benzedeira e outros?
sim não
Qual?
$\operatorname{sim}_{1}$ não 2
h. tratamento com massagens?
$\operatorname{sim}_{1}$ não
i. homeopatia?.
j. outros:
sim não
112
sim não 


\section{Sintomas ou sinais}

As questões a seguir perguntam acerca de SINTOMAS OU SINAIS que sua criança possa ter tido durante as últimas 4 semanas. Por favor, responda $O$ QUANTO DE DESCONFORTO os seguintes sinais ou sintomas causaram em sua criança DURANTE AS ÚLTIMAS 4 SEMANAS.

QUANTO DE DESCONFORTO A SUA CRIANÇA SENTIU COM ESSES SINTOMAS OU SINAIS?

(Por favor circule somente uma resposta para cada questão)

$\begin{array}{ccc}\begin{array}{c}\text { Nem um Muito pouco Pouco } \\ \text { pouco }\end{array} & \begin{array}{c}\text { Moderada Muito Demais } \\ \text { mente } \\ \text { (mais ou } \\ \text { menos) }\end{array}\end{array}$

1. dor física ou no corpo todo?

2. chiado, tosse?

$\begin{array}{llllll}1 & 2 & 3 & 4 & 5 & 6 \\ 1 & 2 & 3 & 4 & 5 & 6\end{array}$

3. náuseas, vômitos, dor abdominal, dor de estômago?...........................

4. diarréia?...........................

5. manchas, coceiras ou outros problemas de pele?

6. fadiga, cansaço,

fraqueza?............................

8. febre, suores noturnos, $\begin{array}{lllllll}\text { tremores e calafrios?........... } & 1 & 2 & 3 & 4 & 5 & 6\end{array}$

9. perda de apetite?............

10. problemas de sono?.....

11. problemas nos olhos ou para enxergar?

12. dor de cabeça?

13. boca seca ou dolorida, problemas para engolir?.... 14. dor ou aperto no peito?

15. dificuldade para respirar ou pegar o ar?.......

16. nariz escorrendo ou problemas de sinusite?....... 17. dor no músculo, nas articulações (juntas) ou nos ossos?........................... 18. dor, formigamento, dormência, paralisia nas mãos ou pés?........................ 19. dor de ouvido?

\begin{tabular}{llllll}
1 & 2 & 3 & 4 & 5 & 6 \\
\hline 1 & 2 & 3 & 4 & 5 & 6
\end{tabular}

$\begin{array}{llllll}1 & 2 & 3 & 4 & 5 & 6\end{array}$

\begin{tabular}{llllll}
1 & 2 & 3 & 4 & 5 & 6 \\
\hline 1 & 2 & 3 & 4 & 5 & 6
\end{tabular}

\begin{tabular}{llllll}
1 & 2 & 3 & 4 & 5 & 6 \\
1 & 2 & 3 & 4 & 5 & 6 \\
\hline 1 & 2 & 3 & 4 & 5 & 6
\end{tabular}

20. desconforto ou mal estar geral? ........ 
Anexo 6: Questionário Quality of Life Assessment

6 meses a 4 anos 
QUALITY OF LIFE ASSESSMENT - REVISED

(For Ages 6 Months - 4 Years)

NIAID AIDS CLINICAL TRIALS GROUP

Patient Number

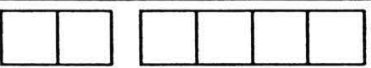

Date of Patient Visit

Protocol Number

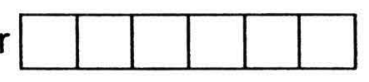

Form Week

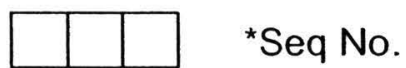

*Seq No.

${ }^{\star \star}$ Step No.

Institution Code
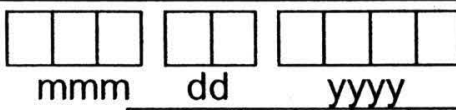

yyyy

*Enter $a$ " 1 " if this is the first of this form for this date. Designate subsequent forms on same date with a 2, 3, etc.

**Enter the subject's current study step number. Enter ' 1 ' if the study does not have multiple steps.

INSTRUCTIONS TO THE STUDY COORDINATOR:

- The following questionnaire should be given to the parent/guardian prior to the clinical exam and preferably in a quiet secluded area (i.e., exam room or other office). The parent/guardian must be able to read at the sixthgrade level at a minimum to complete the form herself/himself. If not, the Study Nurse should complete the form with the individual, using the QUALITY OF LIFE SCALES provided in the CRF Notebook. This guestionnaire should only be given to parent/guardian whose children are between 6 months and 4 years of age

- Pages 1-2 of this clinic form must be completed by the Study Nurse. DO NOT SHOWPAGES $1-2$

OF THIS FORM TO THE PATIENT. Pages $3-8$ are completed by the parent/guardian. Before giving the

questionnaire to the parent/guardian, please fill out the header(s) and DETACH PAGES 1- 2.

- It is important to be familiar with the content and format of the questionnaire before giving it to study participants. At the first visit, please begin by explaining to the parent/guardian the format of the questions and how to complete them

- Each question is in the same general format and contains several items. Note that the patient is always asked to

CIRCLE a number or make an " $X$ " or " $\checkmark$ " next to the appropriate category.

- Collect the completed questionnaire before the clinical exam. Before going on, review the questionnaire for omissions. If the participant missed any of the questions, point this out and have him/her complete the omission. CLINIC SECTION:

QUESTIONS 1 TO 7 ARE TO BE COMPLETED BY THE STUDY NURSE:

COMPLETE QUESTION 1 AND 2 WITH THE HELP OF THE PARENT/GUARDIAN, PRIOR TO GIVING THE QUESTIONNAIRE.

1. Since the last visit, have any of the following occurred?

At Entry: Have any of the following occurred within the last 12 months

(1-Yes, 2-No,

a. Parent lost job:

b. Family member left home:

c. Loss of housing or had to move:

d. Loss of entitlement: (food stamps, AFDC, etc.)

e. Loss of health insurance:

f. Family member hospitalized:

g. Family member very sick:

h. Change of caretaker:

i. Separation of parents:

j. Divorce of parents:

k. Jail sentence of parent:

I. Marriage of parent:

m. Birth of sibling:

n. Mother starting to work:

o. Beginning school or moving to new school:

p. Change in financial status of parents

q. Loss of close friend(to child):

r. Death in family:

If Death in family, who died?

1-Mother

2-Father

3-Brother or sister (stepbrother, or stepsister)

4-Grandparent

9-Other family member 3-Not Known) 
2. Is the subject HIV-infected?

If No, go to question 4.

a. Does the subject know he/she is infected?

If Yes, complete 'a1.'

a1. Age when subject first knew their infection status: (Enter - 1 if unknown).

b. Is the subject in school?

If No, go to question 3 .

c. Does the school know the diagnosis?

NOTE: The following questions should not be asked of the parent/guardian.

(1-Yes, 2-No, 3-Not Known)

3. Has the parent/guardian signed a DNR order on this subject?

4. Has the subject enrolled or been enrolled in hospice care?

ANSWER THE FOLLOWING ITEMS AFTER PARENT/GUARDIAN COMPLETES THE QUESTIONNAIRE OR AFTER YOU ASCERTAIN THAT THIS IS NOT POSSIBLE:

5. How was the questionnaire completed? If " 4 ", complete 'a' and STOP.

1 - Self Administered by the parent/guardian

2 - Face-to-face interview that you conducted

3 - Phone interview

4 - Not completed

If Other, specify: [30]

9 - Other, specify

a. If "4" - Not completed, indicate the reason:

1 - Parent/guardian refused

2 - Patient missed clinic visit

3 - There was not enough time at this visit

If Other, specify: [30]

9 - Other reason

6. Who responded to the questions?

1 - Biological Mother

2 - Biological Father

3 - Other Relative, specify

4 - Adoptive Parent

5 - Foster Parent

If Other or Other Relative, specify: [30]

9 - Other, specify

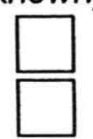


Patient Number

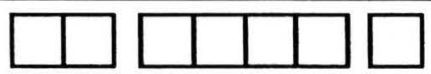

Date of Patient Visit

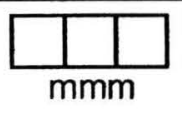

Institution Code

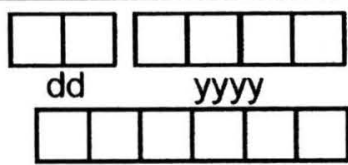

Protocol Number \begin{tabular}{|l|l|l|l|l|l|}
\hline & & & & & \\
\hline
\end{tabular}

Form Week
* Seq. No.

${ }^{\star *}$ Step No.

* Enter a "1" if this is the first of this form for this date. Designate subsequent forms on same date with a 2, 3, etc.

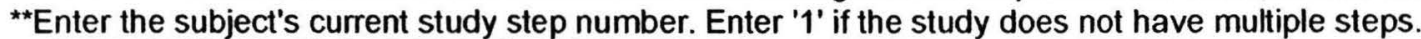

INSTRUCTIONS TO PARENTIGUARDIAN:

Please answer the following questions by circling the best response. There are no right or wrong answers

If you don't know what a particular question means do not hesitate to ask the study nurse. Please do your best to answer all questions.

I. General Health Ratings. These statements ask about the health and behavior of your child.

A. On a scale from 1 to 10 : (1 being the very worst, and 10 being the very best)

HOW HAS YOUR CHILD BEEN FEELING, ON THE AVERAGE, DURING

THE PAST 3 MONTHS?

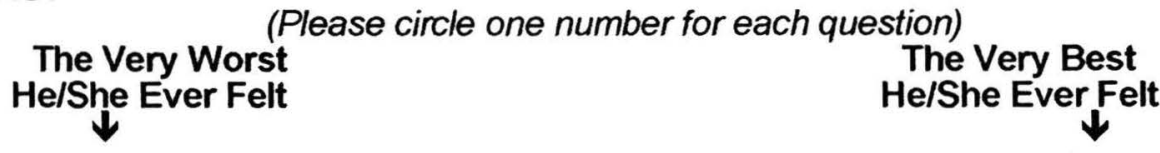

1. Overall, in general? $\begin{array}{llllllllll}1 & 2 & 3 & 4 & 5 & 6 & 7 & 8 & 9 & 10\end{array}$

2. Physically?

\begin{tabular}{llllllllll}
1 & 2 & 3 & 4 & 5 & 6 & 7 & 8 & 9 & 10 \\
\hline
\end{tabular}

3. Emotionally?

\begin{tabular}{llllllllll}
1 & 2 & 3 & 4 & 5 & 6 & 7 & 8 & 9 & 10 \\
\hline
\end{tabular}

B. As you read the following statements, decide which phrase best describes your child's health over the past 3 months, then circle the number that goes with the answer you choose. DURING THE PAST 3 MONTHS ...

(Please circle one number for each question)

$\begin{array}{cc}\text { Never } & \text { Some } \\ \text { or } & \text { of the } \\ \text { Rarely } & \text { Time }\end{array}$

1. My child's health is excellent:

1

1

2. My child seems to resist illness very well:

3. My child seems less healthy than other children I know:....

4. When there is something going around, my child usually catches it:

My child is somewhat clumsy:

6. My child seems accident-prone:

7. When my child is sick or injured, he/she usually recovers quickly:
2

1
2

2

3

3

Always

23

23

3 


\section{Functional Status}

Here are some statements that parents/guardians have made to describe their children. As you read these statements, decide which phrase best describes your child's behavior over the past 3 months, then circle the number that goes with the answer you choose.

Thinking about your child, DURING THE PAST 3 MONTHS, did your child...

(Please circle one number for each question) \begin{tabular}{ccc}
$\begin{array}{c}\text { Never } \\
\text { or }\end{array}$ & $\begin{array}{c}\text { Some } \\
\text { of the }\end{array}$ & $\begin{array}{c}\text { Almost } \\
\text { Rarely }\end{array}$ \\
\hline
\end{tabular}

1. Eat well? 1 2

2. Sleep well? 1

3. Seem contented and cheerful?

4. Act moody?

5. Communicate what he/she wanted?

6. Seem to feel sick and tired?

7. Occupy him/herself?.

8. Seem lively and energetic?

9. Seem unusually irritable or cross?.

10. Sleep through the night?

11. Respond to your attention?

12. Seem unusually difficult?

13. Seem interested in what was going on around him/her?

14. React to little things by crying?

15. Depend on any special medical equipment or appliance in daily living? 
III. Social and Role Functioning (Place an "X" or " $"$ " on the line next to your answer)

A. DURING THE PAST 4 WEEKS, HOW MANY DAYS...

1. Did your child stay in bed (most or all of the day) due to any illness or injury?

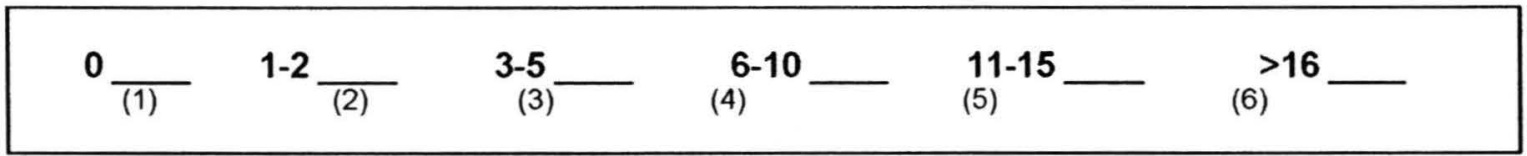

2. Did illness or injury keep your child from school? (If during a vacation period, refer to the last month school was open.)
Not In
School
$\overline{(-1)}^{0}$
(1)
1-2
3-5
(3)
6-10
(4)
$11-15$
$>16$
(6)

B. Please check only one answer for each question:

1. DURING THE PAST 4 WEEKS, did illness or injury limit or prevent your child from doing usual childhood activities such as playing with other children or participating in games or sports?

(Check One)

2. In general, is your child able to take part at all in ordinary play with other children?

3. In general, is your child limited in the kind of play he/she can do because of his/her health?

4. In general, is your child limited in the amount of play because of his/her health?

5. Is your child enrolled in an early intervention program because of his/her health?

$\begin{array}{lll}\text { Yes } \square & \text { No } \square \\ \text { Yes } \square & \text { No } \quad \square \\ \text { Yes } \square & \text { No } \quad \square \\ \text { Yes } \square_{1} & \text { No } \quad \square \\ \text { Yes } \square & \text { No } \quad \square\end{array}$

6. DURING THE PAST 4 WEEKS, who took care of your child for the most daytime hours during a typical weekday?

(Check One)

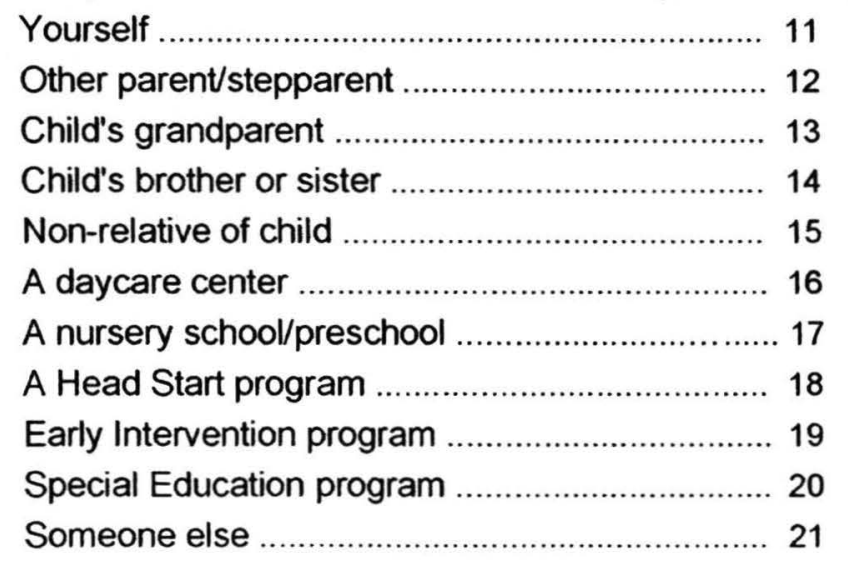


QUALITY OF LIFE ASSESSMENT - REVISED QL4003(000)/00-00-00

(For Ages 6 Months - 4 Years)

Pt. No.

$\square$

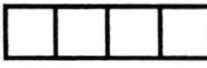

$\square$ * Seq. No.

**Step No.

Date
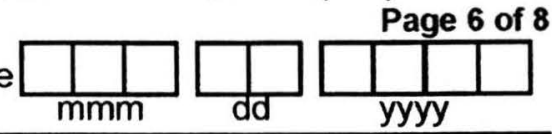

IV. Health Care Utilization (Place an "X" or " $"$ " on the line next to your answer)

A. DURING THE PAST 4 WEEKS...

1. HOW MANY NIGHTS did your child stay in a hospital?

\begin{tabular}{|c|c|c|c|c|c|}
\hline${ }^{0}$ & $1-2$ & $3-5$ & $\begin{array}{r}6-10 \\
(4)\end{array}$ & $11-2$ & $>2$ \\
\hline
\end{tabular}

2. HOW MANY VISITS did your child make to a clinic, office or emergency room to see a doctor, nurse or other specialist?

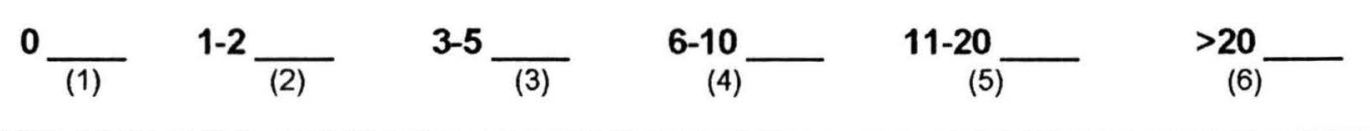

3. HOW MANY TIMES was your child visited by a nurse or other health care provider at your home?

\begin{tabular}{|c|c|c|c|c|c|}
\hline${ }^{0}$ & $1-2 \frac{}{(2)}$ & ${ }^{3-5}$ & $\begin{array}{r}6-10 \\
(4)\end{array}$ & $\begin{array}{r}11-20 \\
(5)\end{array}$ & $\begin{array}{r}>20 \\
(6)\end{array}$ \\
\hline
\end{tabular}

4. HOW MANY TIMES did you call a clinic, physician, nurse, or other health care provider for a medical consultation over the telephone about your child?
${ }^{0}$
$1-2 \frac{}{(2)}$
3-5
(3)
6-10
11-20
(5)
$>20$
(4)
)
(6) 
B. Please check only one box for each question:

DURING THE PAST 4 WEEKS, did illness or injury make it necessary for your child to use any medicine, other than vitamins, that a doctor prescribed?

\section{(Check One)}

Yes $\square_{1}$ No $\square_{2}$

If No, go to "C".

If Yes, which of the following prescription medications did your child use?

Was it necessary for your child to use...

1. Prescription pain medicine?

2. Prescription antibiotics?

3. Prescription cold medicine?

4. Prescription medicine for wheezing?

5. Prescription topical cream?

6. Prescription anti-diarrhea medicine?

\begin{tabular}{|c|c|}
\hline Yes $\square$ & No \\
\hline Yes | & No \\
\hline Yes & No \\
\hline Yes $\square$ & No \\
\hline Yes & \\
\hline Yes L & No \\
\hline Yes & No \\
\hline
\end{tabular}

C. "The following are a list of alternative treatments that you may have provided for your child. These are treatments other than traditional medicines. Since the last clinic visit, has your child had or taken any of the following?"
a. Taking any over the counter herbs?
b. Taking any over the counter vitamins?
c. Had any acupuncture treatments?
d. Taken any yoga?
e. Used aromatherapy?
f. Practiced any specific form of spiritual activity?
g. Used chiropractic care?
h. Used any massage therapy?

$\begin{array}{lll}\text { Yes } \square & \text { No } \square \\ \text { Yes } \square & \text { No } \square \\ \text { Yes } \square & \text { No } \square \\ \text { Yes } \square & \text { No } \\ \text { Yes } \square & \square \\ \text { Yes } \square & \text { No } \\ \text { Yes } \square \\ \text { Yes } \square \\ \text { M } \square\end{array}$


V. Symptoms

The following questions ask about SYMPTOMS OR FEELINGS your child might have had during the past 4 weeks. Please answer HOW DISTRESSING the following symptoms have been for your child DURING THE PAST 4 WEEKS.

HOW MUCH WAS YOUR CHILD DISTRESSED BY THIS SYMPTOM OR FEELING?

Not at Very (Please circle one answerfor each question)
all Mildly Mildly Moderately Much Extremely

1. Physical or bodily pain?

$1 \quad 3$

2. Coughing, wheezing?

3. Nausea, vomiting, abdominal/stomach pain?

$\begin{array}{llllll}1 & 2 & 3 & 4 & 5 & 6 \\ 1 & 2 & 3 & 4 & 5 & 6\end{array}$

\begin{tabular}{|c|c|c|c|c|c|c|}
\hline 4. Diarrhea & 1 & 2 & 3 & 4 & 5 & 6 \\
\hline $\begin{array}{l}\text { 5. Rash, itching, or other } \\
\text { skin problems? }\end{array}$ & 1 & 2 & 3 & 4 & 5 & 6 \\
\hline 6. Fatigue, weakness? & 1 & 2 & 3 & 4 & 5 & 6 \\
\hline 7. Feeling dizzy or lightheaded? & 1 & 2 & 3 & 4 & 5 & 6 \\
\hline $\begin{array}{l}\text { 8. Fever, night sweats, } \\
\text { shaking, chills? }\end{array}$ & 1 & 2 & 3 & 4 & 5 & 6 \\
\hline 9. Loss of appetite? & 1 & 2 & 3 & 4 & 5 & 6 \\
\hline 10. Trouble sleeping? & 1 & 2 & 3 & 4 & 5 & 6 \\
\hline $\begin{array}{l}\text { 11. Eye trouble, problem } \\
\text { with vision? }\end{array}$ & 1 & 2 & 3 & 4 & 5 & 6 \\
\hline 12. Headache? & 1 & 2 & 3 & 4 & 5 & 6 \\
\hline $\begin{array}{l}\text { 13. Dry or painful mouth, } \\
\text { trouble swallowing? }\end{array}$ & 1 & 2 & 3 & 4 & 5 & 6 \\
\hline 14. Chest pain or tightness? & 1 & 2 & 3 & 4 & 5 & 6 \\
\hline $\begin{array}{l}\text { 15. Difficulty breathing or } \\
\text { catching breath? }\end{array}$ & 1 & 2 & 3 & 4 & 5 & 6 \\
\hline 16. Runny nose, sinus trouble? & 1 & 2 & 3 & 4 & 5 & 6 \\
\hline 17. Muscle aches, joint bone pain? & 1 & 2 & 3 & 4 & 5 & 6 \\
\hline $\begin{array}{l}\text { 18. Pain, numbness, or tingling } \\
\text { in hands or feet? }\end{array}$ & 1 & 2 & 3 & 4 & 5 & 6 \\
\hline 19. Earaches? & 1 & 2 & 3 & 4 & 5 & 6 \\
\hline 20. Overall discomfort? & 1 & 2 & 3 & 4 & 5 & 6 \\
\hline
\end{tabular}

THANK YOU VERY MUCH FOR YOUR TIME.

Your efforts will be very valuable in evaluating new therapies. 
Anexo 7: Questionário Quality of Life Assessment

\section{5 a 11 anos}




\section{QUALITY OF LIFE ASSESSMENT - REVISED}

(For Ages 5 - 11 Years)

NIAID AIDS CLINICAL TRIALS GROUP

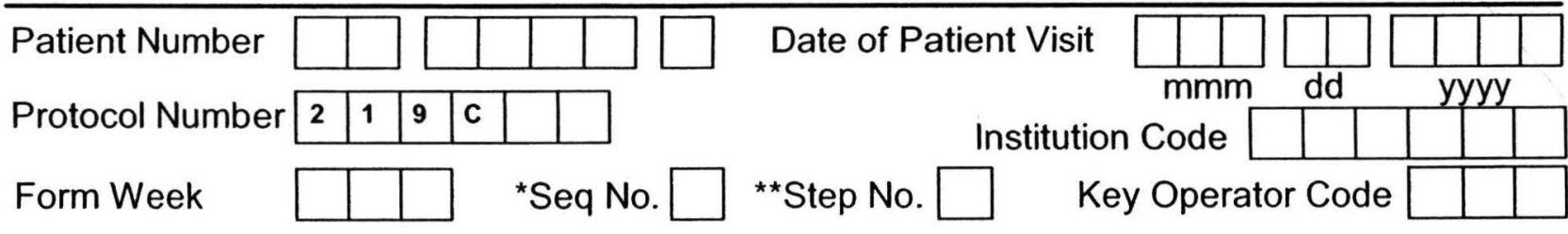

* Enter a " 1 " if this is the first of this form for this date. Designate subsequent forms on same date with a 2, 3, etc.

"Enter the subject's current study step number. Enter ' 1 ' if the study does not have multiple steps.

INSTRUCTIONS TO THE STUDY COORDINATOR:

- The following questionnaire shouldbe given to the parent/guardian prior to the clinical exam and preferably in a quiet secluded area (i.e., exam room or other office). The parent/guardian must be able to read at the sixthgrade level at a minimum to complete the form herself/himself. If not, the Study Nurse should complete the form with the individual, using the QUALITY OF LIFE SCALES provided in the CRF Notebook. This questionnaire should only be given to parent/guardian whose children are between 5 and 11 years of age.

- Pages $1-2$ of this clinic form must be completed by the Study Nurse. DO NOT SHOW PAGES $1-2$ OF THIS FORM TO THE PATIENT. Pages 3-10 are completed by the parent/guardian. Before giving the questionnaire to the parent/guardian, please fill out the header(s) and DETACH PAGES $1-2$.

- It is important to be familiar with the content and format of the questionnaire before giving it to study participants. At the first visit, please begin by explaining to the parent/guardian the format of the questions and how to complete them.

- Each question is in the same general format and contains several items. Note that the patient is always asked to CIRCLE a number or make an "X" or " $\checkmark$ " next to the appropriate category.

- Collect the completed questionnaire before the clinical exam. Before going on, review the questionnaire for

omissions. If the participant missed any of the questions, point this out and have him/her complete the omission.

\section{CLINIC SECTION:}

\section{QUESTIONS 1 TO 7 ARE TO BE COMPLETED BY THE STUDY NURSE:}

COMPLETE QUESTION 1 AND 2 WITH THE HELP OF THE PARENT/GUARDIAN, PRIOR TO GIVING THE QUESTIONNAIRE.

1. Since the last visit, have any of the following occurred?

At Entry: Have any of the following occurred within the last 12 months

a. Parent lost job:

b. Family member left home:

c. Loss of housing or had to move:

d. Loss of entitlement: (food stamps, AFDC, etc.)

e. Loss of health insurance:

f. Family member hospitalized:

g. Family member very sick:

h. Change of caretaker:

i. Separation of parents:

j. Divorce of parents:

k. Jail sentence of parent:

I. Marriage of parent:

$\mathrm{m}$. Birth of sibling:

n. Mother starting to work:

o. Beginning school or moving to new school

p. Change in financial status of parents:

q. Loss of close friend(to child):

r. Death in family:

If Death in family, who died? 
Pt. No.

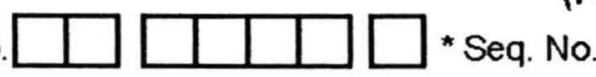

(For Ages 5 - 11 Years)
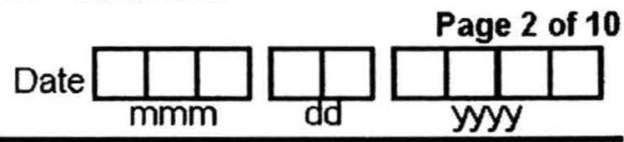

2. Is the subject HIV-infected?

If No, go to question 4.

a. Does the subject know he/she is infected?

If Yes, complete 'a1.'

a1. Age when subject first knew their infection status: (Enter -1 if unknown).

(1-Yes, 2-No)

b. Is the subject in school?

If No, go to question 3.

c. Does the school know the diagnosis?

NOTE: The following questions should not be asked of the parent/guardian. (1-Yes, 2-No,

3. Has the parent/guardian signed a DNR order on this subject?

3-Not Known)

4. Has the subject enrolled or been enrolled in hospice care?

ANSWER THE FOLLOWING ITEMS AFTER PARENT/GUARDIAN COMPLETES THE

QUESTIONNAIRE OR AFTER YOU ASCERTAIN THAT THIS IS NOT POSSIBLE:

5. How was the questionnaire completed?

If "4", complete ' $a$ ' and STOP.

1 - Self Administered by the parent/guardian

2 - Face-to-face interview that you conducted

3 - Phone interview

4 - Not completed

If Other, specify: [30]

9 - Other, specify

a. If "4" - Not completed, indicate the reason:

1 - Parent/guardian refused

2 - Patient missed clinic visit

3 - There was not enough time at this visit

If Other, specify: [30]

9 - Other reason

6. Who responded to the questions?

1 - Biological Mother

2 - Biological Father

3 - Other Relative, specify

4 - Adoptive Parent

5 - Foster Parent

If Other or Other Relative, specify: [30]

9 - Other, specify

7. What language was the questionnaire given in?

1-English

2-Spanish

3-French

4-Creole

If Other, specify: [30]

9-Other

a. What is the primary language spoken at home?

1-English

2-Spanish

3-French

4-Creole

9-Other

If Other, specify: [30]

Date Form Keyed: (DO NOT KEY) 


\section{QUALITY OF LIFE ASSESSMENT - REVISED \\ QL4004(000)/00-00-00 \\ (For Ages 5 - 11 Years) \\ NIAID AIDS CLINICAL TRIALS GROUP}

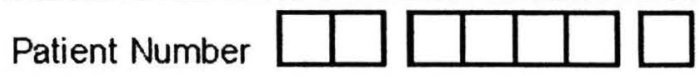

Date of Patient Visit

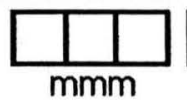

Protocol Number \begin{tabular}{|l|l|l|l|l|l|}
\hline $\mathbf{2}$ & $\mathbf{1}$ & $\mathbf{9}$ & $\mathbf{C}$ & & \\
\hline
\end{tabular}

Institution Code

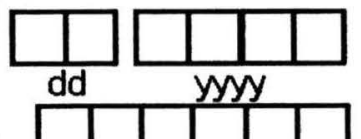

Form Week

* Seq. No. $\square$ **Step No. $\square$

Key Operator Code

"Enter a " 1 " if this is the first of this form for this date. Designate subsequent forms on same date with a 2, 3, etc.

*E Enter the subject's current study step number. Enter ' 1 ' if the study does not have multiple steps.

INSTRUCTIONS TO PARENTIGUARDIAN:

Please answer the following questions by circling the best response. There are no right or wrong answers. If you don't know what a particular question means do not hesitate to ask the study nurse.

Please do your best to answer all questions.

I. General Health Ratings. These statements ask about the health and behavior of your child.

A. On a scale from 1 to 10 (1 being the very worst, and 10 being the very best):

HOW HAS YOUR CHILD BEEN FEELING, ON THE AVERAGE, DURING THE

PAST 3 MONTHS?

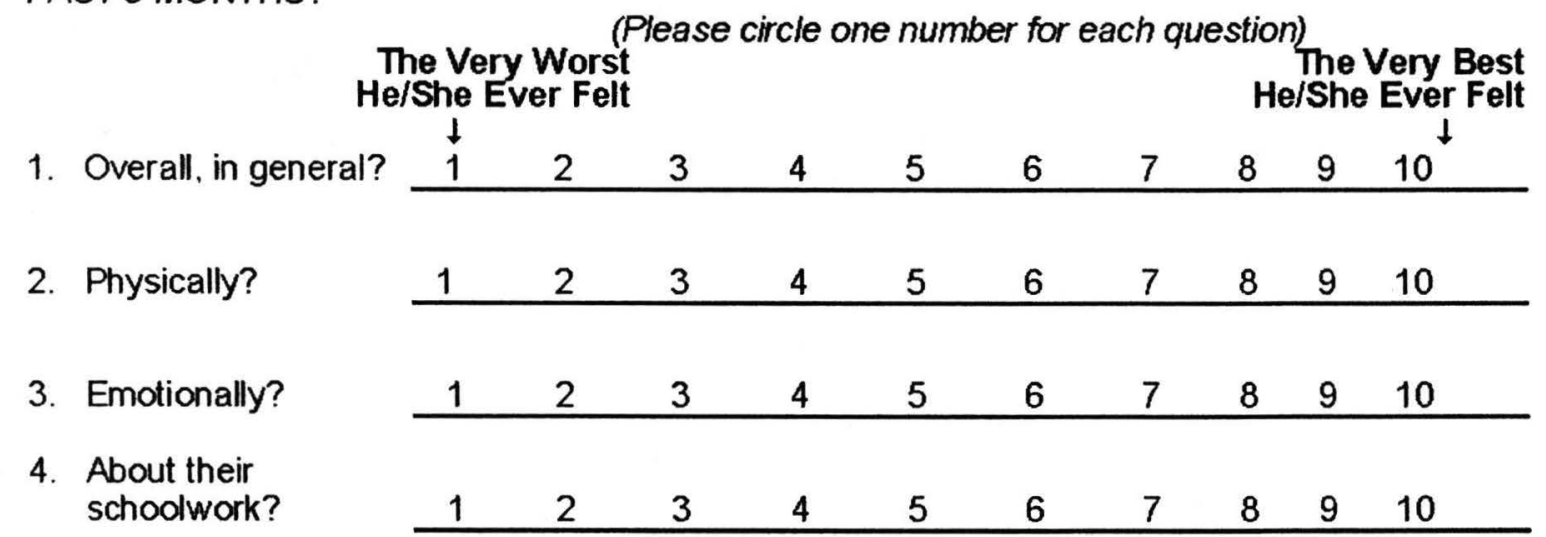

B. As you read the following statements, decide which phrase best describes your child's health over the past 3 months, then circle the number that goes with the answer you choose.

DURING THE PAST 3 MONTHS....

(Please circle one number for each question)

$\begin{array}{cl}\begin{array}{c}\text { Never } \\ \text { or }\end{array} & \begin{array}{l}\text { Some } \\ \text { of the Almost } \\ \text { Rarely }\end{array} \text { Time Alwa }\end{array}$

1. My child's health is excellent:

1

2

3

2. My child seems to resist illness very well:

2

3. My child seems less healthy than other children I know:

1

2

3

4. When there is something going around, my child usually catches it:

5. My child is somewhat clumsy:

6. My child seems accident-prone:

23

7. When my child is sick or injured, he/she usually recovers quickly: 


\section{Physical Functioning}

A. HOW MUCH, if at all, has YOUR CHILD'S HEALTH interfered with his/her activities during the PAST 4 WEEKS?

HOW MUCH HAS YOUR CHILD'S HEALTH INTERFERED WITH...?

1. The kinds or amounts of vigorous activities your child can do, like lifting heavy objects, running, or participating in strenuous sports?

2. The kinds or amounts of moderate activities your child can do, like moving a table. carrying groceries, or moderately active sports like bowling?

3. Walking uphill or climbing a few flights of stairs?

4. Walking one block?

5. Bending, lifting or stooping?

6. Eating, dressing, bathing or using the toilet?
(Please circle one number for each question)

\section{Not at all}

A little

bit

1

2

Moderately

3

4

Quite

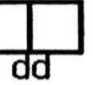

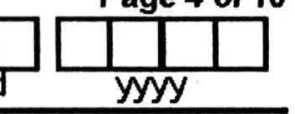


QUALITY OF LIFE ASSESSMENT - REVSED

(For Ages 5 - 11 Years)

Pt. No.
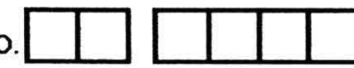

* Seq. No.
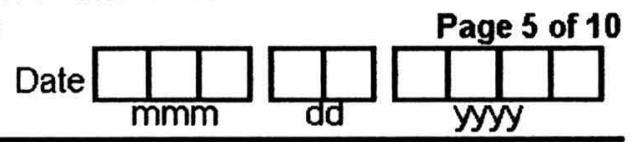

\section{Psychological Well-Being}

These statements are about behavior problems many children have. As you read each sentence, decide which phrase best describes your child's behavior over the past 3 months, then circle the number that goes with the answer you choose.

Thinking about your child, DURING THE PAST 3 MONTHS...

(Please circle one number for each question)

$\begin{array}{lcc} & \text { Some- } & \\ \text { Often } & \text { times } & \text { Not } \\ \text { True } & \text { True } & \text { True }\end{array}$

1. My child has sudden changes in mood or feelings ....... 1123

2. My child feels or complains that no one loves him/her .. 1123

3. My child is rather high strung, tense, and nervous ....... 1123

4. My child cheats or tells lies

1

2

3

5. My child is too fearful or anxious

1

2

3

6. My child argues too much

1

2

3

7. My child has difficulty concentrating.

cannot pay attention for long

1

2

3

8. My child is easily confused, seems to be in a fog

1

2

3

9. My child bullies or is cruel or mean to others

1

2

3

10. My child is disobedient at home

1

2

3

11. My child is disobedient at school

1

2

3

12. My child does not seem to feel

sorry after he/she misbehaves

13. My child has trouble getting along with other children 
QUALITY OF LIFE ASSESSMENT - REVSED

(For Ages 5 - 11 Years)

Pt. No.
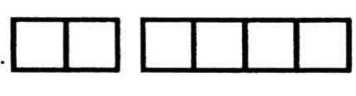

* Seq. No.

*Step No.

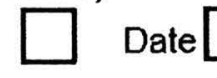

\section{Psychological Well-Being (cont.'d)}

Thinking about your child, DURING THE PAST 3 MONTHS...

(Please circle one number for each question)

$\begin{array}{ccc}\text { Often } & \begin{array}{c}\text { Some- } \\ \text { times }\end{array} & \text { Not } \\ \text { True } & \text { True } & \text { True } \\ \end{array}$

14. My child has trouble getting along with teachers

1

2

3

15. My child is impulsive, or acts without thinking

1

2

3

16. My child feels worthless or inferior

1

2

3

17. My child is not liked by other children

1

2

3

18. My child has a lot of difficulty getting his/her

mind off certain thoughts (has obsessions)

1

2

3

19. My child is restless or overly active, cannot sit still ......

20. My child is stubborn, sullen or irritable

1

2

3

21. My child has a very strong temper and loses it easily ...

1

2

3

22. My child is unhappy, sad or depressed

1

2

3

23. My child is withdrawn, does not get involved with others

1

2

3

24. My child breaks things on purpose, deliberately

destroys his/her own or other's things

25. My child clings to adults 1

2

3

26. My child cries too much

1

2

3

27. My child demands a lot of attention

1

2

28. My child is too dependent on others

1

2 


\section{QUALITY OF LIFE ASSESSMENT - REVSED}

(For Ages 5 - 11 Years)

Page 7 of 10

Pt. No.
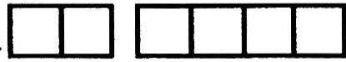

* Seq. No.

$\square *$ Step No.

Date
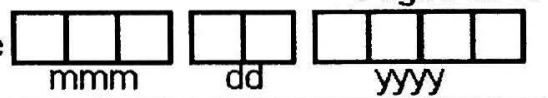

IV. Social and Role Functioning

(Place an " $X$ " or " $\checkmark$ " on the line next to your answer)

A. DURING THE PAST 4 WEEKS, HOW MANY DAYS...

1. Did your child stay in bed (most or all of the day) due to any illness or injury?

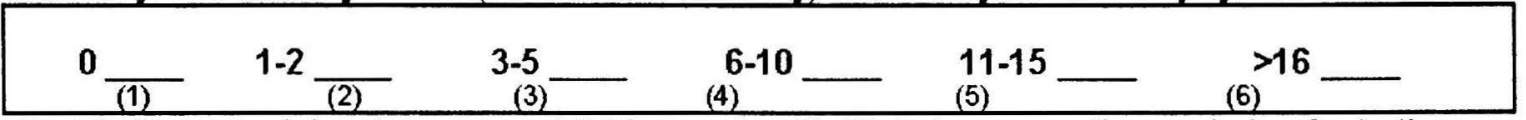

2. Did illness or injury keep your child from school? (If during a vacation period, refer to the last month school was open.)

Nol In

School

$\overline{(-1)}^{0}$

-

$1-2$

3-5

6-10

11-15

$>16$

B. Please check only one answer for each question:

1. What grade is your child in now (or will be in, if between grades)?

Nursery/preschool $\ldots \ldots \ldots \ldots \ldots$
$1^{\text {st }}$ Grade $\ldots \ldots \ldots \ldots$
$2^{\text {nd }}$ Grade $\ldots \ldots \ldots \ldots \ldots$

(Check One)

$11 \square$

$12 \square$

$13 \square$

$14 \square$

$15 \square$

$16 \square$

$17 \square$

$18 \square$

$19 \square$

$99 \square$

2. Has your child ever repeated a grade for any reason?

Yes $\square$

No $\square$

3. In general, is your child limited in school attendance because of his/her health?

4. In general, is your child limited in the kind or amount of other activities because of his/her health?

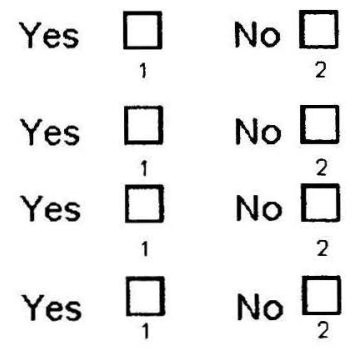

5. In general, has your child participated in school sports?

6. Does your child go to a special class or get special help in school because of a disability or health problem?

If No, go to question 7 .

If Yes, complete ' $a$.'

a. What type of special help does your child receive?

(Check One)

Reading

Learning Disability

Speech or Language

Physical Therapy/Occupational Therapy 14

More than one of above

Other

99

If Other, specify [30]:

7. Is your child receiving home schooling?

Yes 
QUALITY OF LIFE ASSESSMENT - REVSED

(For Ages 5 - 11 Years)

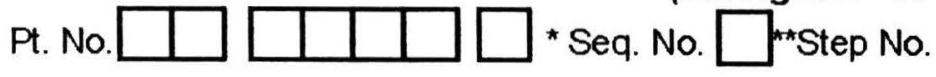

$\square$ Date

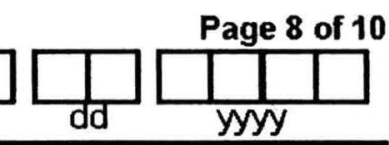

V. Health Care Utilization (Place an "X" or " $\sim$ " on the line next to your answer)

A. DURING THE PAST 4 WEEKS...

1. HOW MANY NIGHTS did your child stay in a hospital?

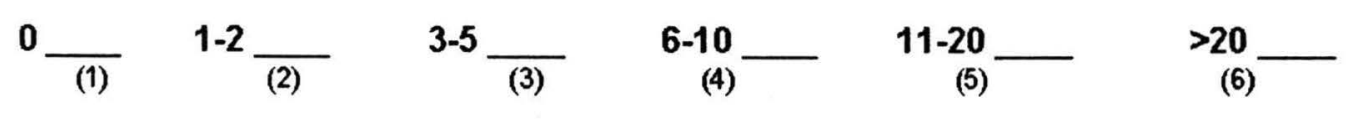

2. HOW MANY VISITS did your child make to a clinic, office or emergency room to see a doctor, nurse or other specialist?

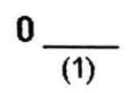
$1-2 \frac{}{(2)}$
3-5
6-10
(4)
$11-20$
$>20$
(5)
(6)

3. HOW MANY TIMES was your child visited by a nurse or other health care provider at your home?
$0_{\text {(1) }}$
$1-2 \frac{}{(2)}$
3-5
6-10
(4)
11-20
(5)
(6)

4. HOW MANY TIMES did you call a clinic, physician, nurse, or other health care provider for a medical consultation over the telephone about your child?
0
$1-2 \frac{}{(2)}$
3-5
6-10
11-20
(5)
$>20$
(4)
)
(6) 
B. Please check only one box for each question:

DURING THE PAST 4 WEEKS, did illness or injury make it necessary

(Check One) for your child to use any medicine, other than vitamins, that a doctor prescribed?

If No, go to "C".".

If Yes, which of the following prescription medications did your child use?

Was it necessary for your child to use...

1. Prescription pain medicine?

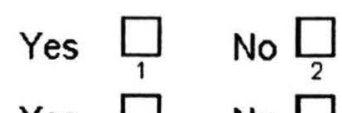

2. Prescription antibiotics?

3. Prescription cold medicine?

4. Prescription medicine for wheezing?

5. Prescription topical cream?

6. Prescription anti-diarrhea medicine?

Yes $\square$ No $\square$

Yes $\square$ No $\square$

Yes $\square \quad$ No $\square$

Yes $\square$ No $\square$

Yes $\square \quad$ No $\square$

C. "The following are a list of alternative treatments that you may have provided for your child.

These are treatments other than traditional medicines. Since the last clinic visit, has your child had or taken any of the following?"

1. Taking any over the counter herbs?

2. Taking any over the counter vitamins?

Yes $\square$ No $\square$

3. Had any acupuncture treatments?

Yes $\square \quad$ No $\square$

4. Taken any yoga?

Yes

No $\square$

5. Used aromatherapy?

Yes

No $\square$

6. Practiced any specific form of spiritual activity?

Yes

No $\square$

7. Used chiropractic care?

Yes

No $\square$

8. Used any massage therapy?

Yes

No $\square$

Yes

No $\square$ 
QL4004(000)/00-00-00

QUALITY OF LIFE ASSESSMENT - REVSED

(For Ages 5 - 11 Years)

Pt. No.
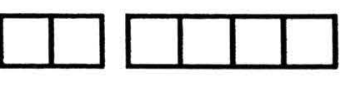

* Seq. No.

*Step No.
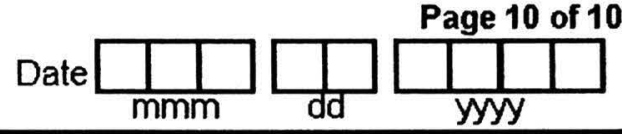

VI. Symptoms

The following questions ask about SYMPTOMS OR FEELINGS your child might have had during the past 4 weeks. Please answer HOW DISTRESSING the following symptoms have been for your child DURING THE PAST 4 WEEKS.

HOW MUCH WAS YOUR CHILD DISTRESSED BY THIS SYMPTOM OR FEELING?

(Please circle one answer for each question)

Not at Very
all Mildly Mildly Moderately Much Extremely

1. Physical or bodily pain?

23

$\begin{array}{lll}4 & 5 & 6\end{array}$

2. Coughing, wheezing?

12

$\begin{array}{lll}1 & 2 & 3\end{array}$

56

3. Nausea, vomiting.

$\begin{array}{lll}1 & 2 & 3\end{array}$

4

$5 \quad 6$ abdominal/stomach pain?

4. Diarrhea

5. Rash, itching, or other skin problems?

$\begin{array}{llllll}1 & 2 & 3 & 4 & 5 & 6 \\ 1 & 2 & 3 & 4 & 5 & 6\end{array}$

6. Fatigue, weakness?

1

7. Feeling dizzy or lightheaded?

8. Fever, night sweats, shaking, chills?

9. Loss of appetite?

23

4

$5 \quad 6$

10. Trouble sleeping?

11. Eye trouble, problem with vision?

23

2

3

4

56

12. Headache?

13. Dry or painful mouth, trouble swallowing?

$\begin{array}{lll}1 & 2\end{array}$

4

56

1

14. Chest pain or tightness?

15. Difficulty breathing or catching breath?

$\begin{array}{llllll}1 & 2 & 3 & 4 & 5 & 6 \\ 1 & 2 & 3 & 4 & 5 & 6 \\ 1 & 2 & 3 & 4 & 5 & 6\end{array}$

16. Runny nose, sinus trouble?

17. Muscle aches, joint bone pain? 1

18. Pain, numbness, or tingling in hands or feet?

19. Earaches?
20. Overall discomfort?

$\begin{array}{lll}1 & 2 & 3 \\ 1 & 2 & 3\end{array}$

THANK YOU VERY MUCH FOR YOUR TIME.

Your efforts will be very valuable in evaluating new therapies. 
Anexo 8: Questionário Quality of Life Assessment

12 a 20 anos 


\section{QUALITY OF LIFE ASSESSMENT - REVISED}

(For Ages 12 - 20 Years)

NIAID AIDS CLINICAL TRIALS GROUP

Patient Number

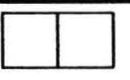

Protocol Number

Form Week
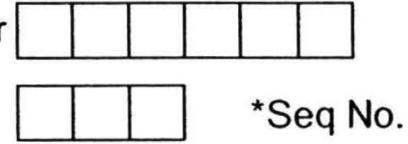

Date of Patient Visit

Institution Code

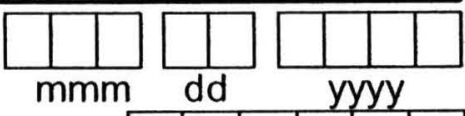

Key Operator Code

* Enter a " 1 " if this is the first of this form for this date. Designate subsequent forms on same date with a 2, 3, etc.

**Enter the subject's current study step number. Enter ' 1 ' if the study does not have multiple steps.

INSTRUCTIONS TO THE STUDY COORDINATOR:

- The following questionnaire should be given to the parent/guardian prior to the clinical exam and preferably in a quiet secluded area (i.e., exam room or other office). The parent/guardian must be able to read at the sixthgrade level at a minimum to complete the form herself/himself. If not, the Study Nurse should complete the form with the individual, using the QUALITY OF LIFE SCALES provided in the CRF Notebook. This questionnaire should only be given to parent/guardian whose children are between 12 and 20 years of age.

- Pages 1-2 of this clinic form must be completed by the Study Nurse. DO NOT SHOWPAGES 1 - 2

OF THIS FORM TO THE PATIENT. Pages 3 - 8 are completed by the parentguardian. Before giving the questionnaire to the parent/guardian, please fill out the header(s) and DETACH PAGES 1 - 2 .

- It is important to be familiar with the content and format of the questionnaire before giving it to study participants. At the first visit, please begin by explaining to the parent/guardian the format of the questions and how to complete them.

- Each question is in the same general format and contains several items. Note that the patient is always asked to CIRCLE a number or make an " $X$ " or " $\checkmark$ " next to the appropriate category.

- Collect the completed questionnaire before the clinical exam. Before going on, review the questionnaire for omissions. If the participant missed any of the questions, point this out and have him/her complete the omission.

CLINIC SECTION:

\section{QUESTIONS 1 TO 7 ARE TO BE COMPLETED BY THE STUDY NURSE:}

COMPLETE QUESTION 1 AND 2 WITH THE HELP OF THE PARENT/GUARDIAN, PRIOR TO GIVING THE QUESTIONNAIRE.

1. Since the last visit, have any of the following occurred?

At Entry: Have any of the following occurred within the last 12 months

a. Parent lost job:

(1-Yes, 2-No,

b. Family member left home:

c. Loss of housing or had to move:

d. Loss of entitlement: (food stamps, AFDC, etc.)

e. Loss of health insurance:

f. Family member hospitalized:

g. Family member very sick:

h. Change of caretaker:

i. Separation of parents:

j. Divorce of parents:

k. Jail sentence of parent:

I. Marriage of parent:

$\mathrm{m}$. Birth of sibling:

n. Mother starting to work:

o. Beginning school or moving to new school:

p. Change in financial status of parents:

q. Loss of close friend(to child):

$r$. Death in family:

If Death in family, who died?

1-Mother

2-Father

3-Brother or sister (stepbrother, or stepsister)

4-Grandparent

9-Other family member

3-Not Known)

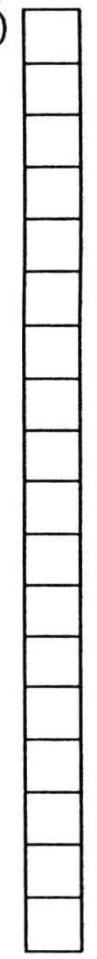

$11-15-02 / 05-1403$ 

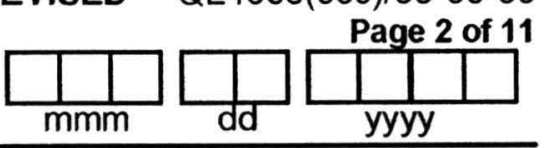

(1-Yes, 2-No)

2. Is the subject HIV-infected?

If No, go to question 4.

a. Does the subject know he/she is infected?

If Yes, complete 'a1.'

a1. Age when subject first knew their infection status: (Enter - 1 if unknown)

b. Is the subject in school?

If No, go to question 3 .

c. Does the school know the diagnosis?

NOTE: The following questions should not be asked of the parent/guardian.

(1-Yes, 2-No, 3-Not Known)

3. Has the parent/guardian signed a DNR order on this subject?

4. Has the subject enrolled or been enrolled in hospice care?

\section{ANSWER THE FOLLOWING ITEMS AFTER PARENT/GUARDIAN COMPLETES THE} QUESTIONNAIRE OR AFTER YOU ASCERTAIN THAT THIS IS NOT POSSIBLE:

5. How was the questionnaire completed?

If " 4 ", complete 'a' and STOP.

If Other, specify: [30]

a. If "4" - Not completed, indicate the reason:

If Other, specify: [30]

6. Who responded to the questions?

If " 6 " or "7", subject should only complete Section IV

questions $A 1$ and 2, B1, 2, 5, 6, 7, Section V questions

$B 1-6$, and $C$, and Section VI questions $1-20$.

If Other or Other Relative, specify: [30]

7. What language was the questionnaire given in?

If Other, specify: [30]

a. What is the primary language spoken at home?

If Other, specify: [30]
1 - Biological Mother

2 - Biological Father

3 - Other Relative, specify

4 - Adoptive Parent

5 - Foster Parent

6 - Emancipated minor

7 - Subject themself (no

longer in care of

parent/guardian)

9 - Other, specify
1-English

2-Spanish

3-French

4-Creole

9-Other

1-English

2-Spanish

3-French

4-Creole

9-Other

\section{$\square$}
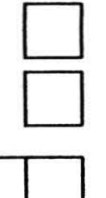

$\square$

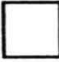

\section{n)}




\section{QUALITY OF LIFE ASSESSMENT - REVISED}

(For Ages 12 - 20 Years)

Patient Number

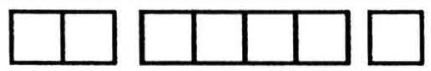

Date of Patient Visit

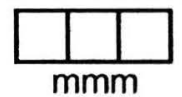

Protocol Number

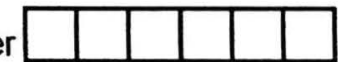

Institution Code

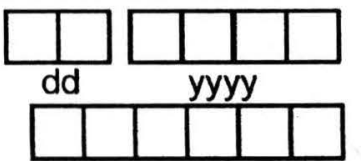

Form Week

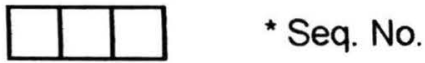

${ }^{\star}$ Step No

Key Operator Code

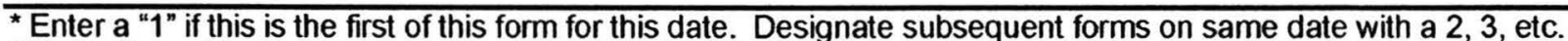

**Enter the subject's current study step number. Enter ' 1 ' if the study does not have multiple steps.

INSTRUCTIONS TO PARENTIGUARDIAN:

Please answer the following questions by circling the best response. There are no right or wrong answers. If you don't know what a particular question means do not hesitate to ask the study nurse. Please do your best to answer all questions.

I. General Health Ratings. These statements ask about the health and behavior of your child.

A. On a scale from 1 to 10 ( 1 being the very worst, and 10 being the very best):

HOW HAS YOUR CHILD BEEN FEELING, ON THE AVERAGE, DURING THE PAST 3 MONTHS?

(Please circle a number between 1 and 10 in each question)

The Very Worst

He/She Ever Felt
The Very Best He/She Ever Felt

1. Overall, in general?

12

$3 \quad 4 \quad 5$ 6 $\begin{array}{llll}7 & 8 & 9 & 10\end{array}$

2. Physically? 45 6 $\begin{array}{llll}7 & 8 & 9 & 10\end{array}$

3. Emotionally?

$\begin{array}{llllllllll}1 & 2 & 3 & 4 & 5 & 6 & 7 & 8 & 9 & 10\end{array}$

4. About their usual daily activities, such as schoolwork, job or housework? 1 23 $4 \quad 5$ $\begin{array}{lllll}6 & 7 & 8 & 9 & 10\end{array}$ 


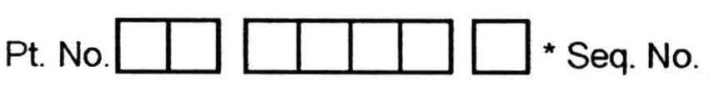

LIFE ASSESSMENT - REV
(For Ages $12-20$ Years)

QL4005(000)/00-00-00

QUALITY OF LIFE ASSESSMENT - REVISED

Date $\mathrm{mmm}$

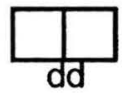

Page 4 of 11

\section{Physical Functioning}

A. HOW MUCH, if at all, has YOUR CHILD'S HEALTH interfered with his/her activities during the PAST 4 WEEKS?

(Please circle one number for each question)

HOW MUCH HAS YOUR CHILD'S HEALTH INTERFERED WTH...?

1. The kinds or amounts of vigorous activities your child can do, like lifting heavy objects, running, or participating in strenuous sports?

2. The kinds or amounts of moderate activities your child can do, like moving a table, carrying groceries, or moderately active sports like bowling?

3. Walking uphill or climbing a few flights of stairs?

\section{Walking one block?}

5. Bending, lifting or stooping?

6. Eating, dressing, bathing or using the toilet?

$\begin{array}{ccc}\begin{array}{c}\text { Not } \\ \text { at all little } \\ \text { bit }\end{array} \text { Moderately } & \begin{array}{c}\text { Quite } \\ \text { a bit }\end{array}\end{array}$

$\begin{array}{lllll}1 & 2 & 3 & 4 & 5\end{array}$

1

2

3

4

5 


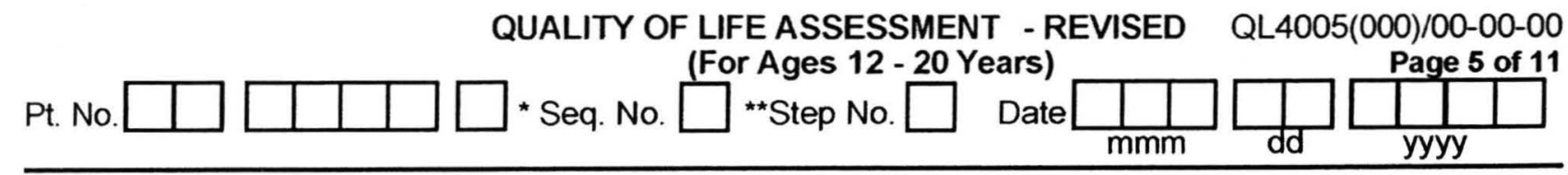

\section{Psychological Well-Being}

These statements are about behavior problems many children have. As you read each sentence, decide which phrase best describes your child's behavior over the past 3 months, then circle the number that goes with the answer you choose.

Thinking about your child, DURING THE PAST 3 MONTHS...

(Please circle one number for each question)

$\begin{array}{ccc} & \text { Some- } & \\ \text { Often } & \text { times } & \text { Not } \\ \text { True } & \text { True } & \text { True }\end{array}$

1. My child has sudden changes in mood or feelings ....... 1123

2. My child feels or complains that no one loves him/her .. 113

3. My child is rather high strung, tense, and nervous ....... 11213

4. My child cheats or tells lies ........................... 112

5. My child is too fearful or anxious ........................ 1 2

6. My child argues too much ............................. 112

7. My child has difficulty concentrating, cannot pay attention for long

123

8. My child is easily confused, seems to be in a fog ....... 1123

9. My child bullies or is cruel or mean to others ............ 112

10. My child is disobedient at home .......................

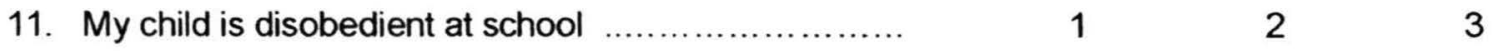

12. My child does not seem to feel sorry after he/she misbehaves

13. My child has trouble getting along with other children 
QUALITY OF LIFE ASSESSMENT - REVISED QL4005(000)/00-00-00 Pt. No. (For Ages 12 - 20 Years)

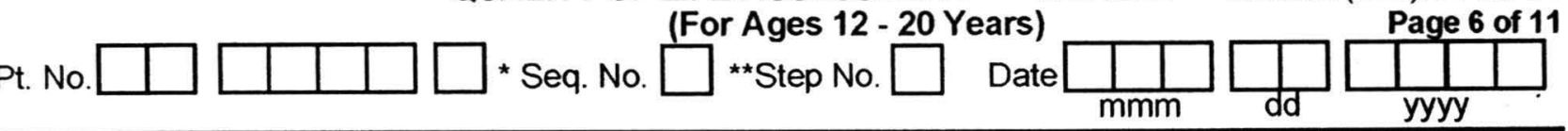

\section{Psychological Well-Being (cont.'d)}

Thinking about your child, DURING THE PAST 3 MONTHS...

(Please circle one number for each question)

$\begin{array}{lll}\text { Often } & \text { Some- } & \text { Nimes } \\ \text { True } & \text { True } & \text { True }\end{array}$

14. My child has trouble getting along with teachers

1

2

3

15. My child is impulsive, or acts without thinking

16. My child feels worthless or inferior 1

2

3

17. My child is not liked by other children 1

18. My child has a lot of difficulty getting his/her mind off certain thoughts (has obsessions)

23

19. My child is restless or overly active, cannot sit still ...... 1 2 3

20. My child is stubborn, sullen or irritable 1 2 3

21. My child has a very strong temper and loses it easily ... 1 2

22. My child is unhappy, sad or depressed 1 2 3

23. My child is withdrawn, does not get involved with others 1

24. My child feels others are out to get him/her 1

25. My child hangs around with kids who get into trouble .... 1 2 3

26. My child is secretive, keeps things to himself/herself .... 1 2 3

27. My child worries too much 1 2

28. My child is too dependent on others 1 2 


\section{Social and Role Functioning}

A. Thinking about you/your child, during the past 4 weeks, how many days

(Place an "X" or " $\curvearrowleft$ " on the line next to your answer)

1. Did you/your child stay in bed (most or all of the day) due to any illness or injury?

\begin{tabular}{|c|c|c|c|c|c|}
\hline${ }^{0}$ & $1-2$ & $\begin{array}{r}3-5 \\
(3) \\
\end{array}$ & $\begin{array}{l}6-10 \\
(4)\end{array}$ & $\begin{array}{l}11-15 \\
(5)\end{array}$ & ${ }_{(6)}^{>16}$ \\
\hline
\end{tabular}

2. Did illness or injury keep you/your child from school?

(If during a vacation period, refer to the last month school was open.)

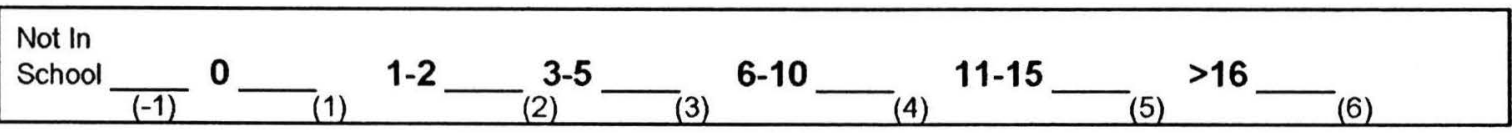

B. Check only one for each question:

1. What grade is you/your child in now (or will be in, if between grades)?

(Check One)

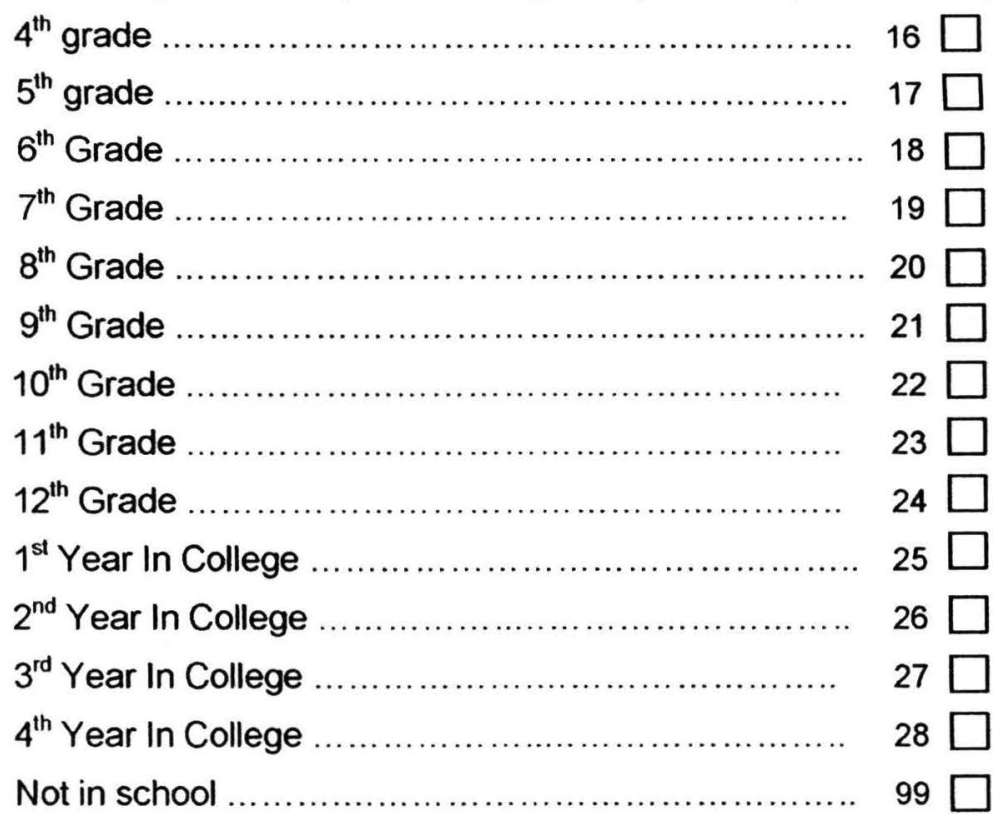


2. Have you/your child ever repeated a grade for any reason?

(Check One)

Yes $\square$ No $\square$

3. In general, are you/your child limited in school attendance because

of his/her health?

Yes $\square$ No $\square$

4. In general, are you/your child limited in the kind or amount of other activities because of his/her health?

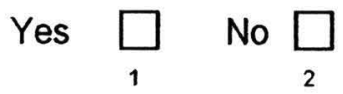

5. In general, have you/your child participated in school sports?

Yes $\square$ No $\square$

6. Does you/your child go to a special class or get special help in school because of a disability or health problem? If No, go to question 7. If Yes, complete 'a.'

Yes $\square_{1}$ No $\square_{2}$

a. What type of special help do you/your child receive? ...

1 - Reading

2 - Learning disability

3 - Speech or Language

4 - Physical Therapy/

Occupational Therapy

5 - More than one of above

9 - Other, specify

(Check One'

If Other, specify [30]:

7. Are you/your child receiving home schooling?

Yes $\square_{1}$ No $\square_{2}$ 
QUALITY OF LIFE ASSESSMENT - REVISED QL4005(000)/00-00-00

Pt. No.
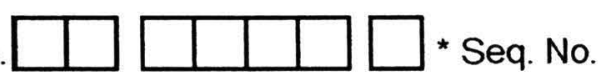

(For Ages 12 - 20 Years)

Page 9 of 11

V. Health Care Utilization (Place an "X" or " $\sim$ " on the line next to your answer)

A. DURING THE PAST 4 WEEKS...

1. HOW MANY NIGHTS did you/your child stay in a hospital?

\begin{tabular}{|c|c|c|c|c|c|}
\hline $0^{0}$ & $1-2$ & $3-5 \frac{}{(3)}$ & $\begin{array}{r}6-10 \\
(4)\end{array}$ & $\begin{array}{r}11-20 \\
(5)\end{array}$ & $\begin{array}{r}>20 \\
(6)\end{array}$ \\
\hline
\end{tabular}

2. HOW MANY VISITS did you/your child make to a clinic, office or emergency room to see a doctor, nurse or other specialist?
o
$1-2 \frac{}{(2)}$
3-5
(3)
6-10
(4)
11-20
(5)
$>20$
(6)

$\left.\right|_{\text {yyyy }}$ 
QUALITY OF LIFE ASSESSMENT -REVISED QL4005(000)/00-00-00 Pt. No $\square \square \square\left(\begin{array}{lll}\hline \\ \hline\end{array} \square\right.$ * (For Ages $12-20$ Years)

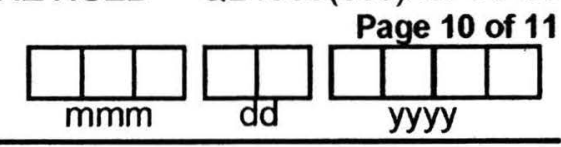

B. Please check only one box for each question:

DURING THE PAST 4 WEEKS, did illness or injury make it necessary

(Check One) for you/your child to use any medicine, other than vitamins, that a doctor prescribed?

If No, go to "C".

Yes

No

If Yes, which of the following prescription medications did you/your child use?

Was it necessary for you/your child to use...

1. Prescription pain medicine?

Yes $\square \quad$ No $\square$

2. Prescription antibiotics?

3. Prescription cold medicine?

Yes $\square$ No $\square$

4. Prescription medicine for wheezing?

Yes $\square$ No $\square$

5. Prescription topical cream?

Yes $\square$ No $\square$

6. Prescription anti-diarmea medicine?

Yes $\square \quad$ No $\square$

Yes $\square \quad$ No $\square$

C. "The following are a list of alternative treatments that you may have taken/provided for your child. These are treatments other than traditional medicines. Since the last clinic visit, has you/your child had or taken any of the following?"

a. Taking any over the counter herbs?

b. Taking any over the counter vitamins?

Yes $\square \quad$ No $\square$

c. Had any acupuncture treatments?

d. Taken any yoga?

e. Used aromatherapy?

f. Practiced any specific form of spiritual activity?

Yes $\square \quad$ No $\square$

Yes $\square$ No $\square$

Yes $\square$ No $\square$

g. Used chiropractic care?

h. Used any massage therapy?

Yes $\square$ No $\square$

Yes $\square$ No $\square$

Yes $\square$ No $\square$

Yes $\square \quad$ No $\square$ 


\section{Symptoms}

The following questions ask about SYMPTOMS OR FEELINGS you/your child might have had during the past 4 weeks. Please answer HOW DISTRESSING the following symptoms have been for you/your child DURING THE PAST 4 WEEKS.

HOW MUCH WAS YOU/YOUR CHILD DISTRESSED BY THIS SYMPTOM OR FEELING?

$$
\text { (Please circle one answer for each question) }
$$

$$
\begin{gathered}
\text { Not at Very } \\
\text { all } \\
\text { Mildly }
\end{gathered}
$$

1. Physical or bodily pain?

12

Mildly

Moderately

Very

2. Coughing, wheezing?

3. Nausea, vomiting, abdominal/stomach pain?

$\begin{array}{llllll}1 & 2 & 3 & 4 & 5 & 6 \\ 1 & 2 & 3 & 4 & 5 & 6\end{array}$

4. Diarrhea

$\begin{array}{llllll}1 & 2 & 3 & 4 & 5 & 6 \\ 1 & 2 & 3 & 4 & 5 & 6\end{array}$

5. Rash, itching, or other skin problems?

6. Fatigue, weakness?

$\begin{array}{lll}1 & 2 & 3\end{array}$

7. Feeling dizzy or lightheaded?

8. Fever, night sweats, shaking, chills?

9. Loss of appetite?

123

34

$5 \quad 6$

10. Trouble sleeping?

11. Eye trouble, problem with vision?

123

56

3

5

6

(n)

$1 \quad 2 \quad 3$

12. Headache?

$\begin{array}{llllll}1 & 2 & 3 & 4 & 5 & 6 \\ 1 & 2 & 3 & 4 & 5 & 6 \\ & 4 & 5 & 6\end{array}$

\begin{tabular}{lllllll} 
12. Headache? & 1 & 2 & 3 & 4 & 5 & 6 \\
\hline $\begin{array}{l}\text { 13. Dry or painful mouth, } \\
\text { trouble swallowing? }\end{array}$ & 1 & 2 & 3 & 4 & 5 & 6
\end{tabular}

$\begin{array}{lllllll}\text { 14. Chest pain or tightness? } & 1 & 2 & 3 & 4 & 5 & 6 \\ \text { 15. Difficulty breathing or } & 1 & 2 & 3 & 4 & 5 & 6\end{array}$
catching breath?

\begin{tabular}{lllllll}
\hline 16. Runny nose, sinus trouble? & 1 & 2 & 3 & 4 & 5 & 6 \\
$\begin{array}{l}\text { 17. Muscle aches, joint bone pain? } \\
\begin{array}{l}\text { 18. Pain, numbness, or tingling } \\
\text { in hands or feet? }\end{array}\end{array}$ & 1 & 2 & 3 & 4 & 5 & 6 \\
\hline 19. Earaches? & 1 & 2 & 3 & 4 & 5 & 6 \\
20. Overall discomfort? & 1 & 2 & 3 & 4 & 5 & 6
\end{tabular}

THANK YOU VERY MUCH FOR YOUR TIME.

Your efforts will be very valuable in evaluating new therapies. 


\section{Anexo 9: Questionário de adesão do estudo PERA}

Sabemos que pode ser difícil administrar rotineiramente os medicamentos anti-retrovirais às crianças. Estamos interessados em descobrir como é para o Senhor e a sua família. Por favor, marque a resposta que melhor descrever a sua verdadeira situação ou suas opiniões; as suas respostas podem ser de ajuda para outras pessoas no futuro. Obrigado.

Número do paciente: .Nome do entrevistador

No. do prontuário do Paciente:

Data de preenchimento:

1) Qual é a sua relação com a criança ? Mãe $\square$ Pai $\square$

Outra (favor especifique)

2) Quem mais pode dar os medicamentos à criança?

3) A sua criança toma facilmente os medicamentos anti-retrovirais? (Escreva o nome dos medicamentos que a criança está a tomando agora.)

\begin{tabular}{|l|l|l|l|l}
\hline Nome medicamento & & & & \\
\hline & $\square$ bastante fácil & $\square$ fácil & $\square$ alguma dificuldade & $\square$ grande dificuldade \\
\hline & $\square$ bastante fácil & $\square$ fácil & $\square$ alguma dificuldade & $\square$ grande dificuldade \\
\hline & $\square$ bastante fácil & $\square$ fácil & $\square$ alguma dificuldade & $\square$ grande dificuldade \\
\hline & $\square$ bastante fácil & $\square$ fácil & $\square$ alguma dificuldade & $\square$ grande dificuldade \\
\hline
\end{tabular}

Se a criança tiver dificuldade em tomar qualquer medicamento, por favor, explique porque:

4) Qual é a dose mais difícil, se houver, para o Senhor?

nenhuma $\square$ de manhã $\square$ no almoço/depois da escola $\square$ tarde $\square$ todas $\square$

5) Qual é a dose mais difícil, se houver, para a criança?

nenhuma $\square \quad$ de manhã $\square$ no almoço/depois da escola $\square$ tarde $\square \quad$ todas $\square$

6L O Senhor lembra-se facilmente de dar os medicamentos à sua criança ?

facilmente $\square$ mais ou menos fácil $\square \quad$ alguma dificuldade $\square$ grande dificuldade

72 Quanto interfere a tomada de medicamentos na vida quotidiana sua e da criança?

Como?

muito $\square$ bastante $\square$ não muito $\square$ nada

8) O senhor pensa que seja importante tomar os medicamentos na maneira indicada pelo médico (por exemplo, lembrar de tomar todas as doses?)

Extremamente $\square \quad$ Muito $\square \quad$ Não sei $\square \quad$ Não muito $\square \quad$ De jeito nenhum $\square$ 
9) Se algum medicamento deve ser tomado com comida. Sempre foi dado com comida?

\begin{tabular}{|l|lc|}
\hline Nome do medicamento & Sim & Não \\
\hline & $\square$ & $\square$ \\
\hline & $\square$ & $\square$ \\
\hline & $\square$ & $\square$ \\
\hline
\end{tabular}

10) Se algum medicamento deve ser tomado antes de comer. Você tem sido capaz de o fazer?

\begin{tabular}{|c|cc|}
\hline Nome do medicamento & Sim & Não \\
\hline & $\square$ & $\square$ \\
\hline & $\square$ & $\square$ \\
\hline & $\square$ & $\square$ \\
\hline
\end{tabular}

11) A quais horas o Senhor dá habitualmente os medicamentos?

\begin{tabular}{|c|c|c|c|}
\hline Nome do medicamento & & & \\
\hline & $1^{\mathrm{a}}$ dose & $2^{a}$ dose & $3^{\mathrm{a}}$ dose \\
\hline & $1^{\text {a }}$ dose & $2^{\mathrm{a}}$ dose & $3^{\mathrm{a}}$ dose \\
\hline & $1^{\mathrm{a}}$ dose & $2^{\mathrm{a}}$ dose & $3^{\mathrm{a}}$ dose \\
\hline & $1^{\mathrm{a}}$ dose & $2^{a}$ dose & $3^{\mathrm{a}}$ dose \\
\hline
\end{tabular}

12) Se a criança não tomou algumas doses, favor indique a razão(ões):

\begin{tabular}{|l|c|}
\hline Porque : & \\
\hline O senhor não estava em casa? & $\square$ \\
\hline Estava demasiado ocupado com outras coisas a fazer? & $\square$ \\
\hline Esqueceu? & $\square$ \\
\hline Queria evitar situações desagradáveis? & $\square$ \\
\hline Não queria que outros soubessem que a sua criança estava tomando estes medicamentos? & $\square$ \\
\hline Sua rotina estava diferente do normal? & $\square$ \\
\hline Acha que estes medicamentos são tóxicos ou prejudiciais? & $\square$ \\
\hline O Senhor estava dormindo na hora de dar os medicamentos? & $\square$ \\
\hline A criança estava dormindo na hora de tomar os medicamentos? & $\square$ \\
\hline A criança estava indisposta? & $\square$ \\
\hline O Senhor estava deprimido demais ou indisposto? & $\square$ \\
\hline A criança tem problemas em tomar algum medicamento (sem ou com comida)? & $\square$ \\
\hline Está farto de dar os medicamentos? & $\square$ \\
\hline
\end{tabular}

13) Nos últimos 3 dias, pode dizer quantas vezes a criança não tomou uma dose:

\begin{tabular}{|l|l|l|l|}
\hline Medicamento & Ontem & Anteontem & 3 dias atrás \\
\hline & $\ldots \ldots$ dose(s) não tomada & $\ldots \ldots$ dose(s) não tomada & $\ldots \ldots$ dose(s) não tomada \\
\hline & $\ldots \ldots$ dose(s) não tomada & $\ldots \ldots$ dose(s) não tomada & $\ldots \ldots$ dose(s) não tomada \\
\hline & $\ldots \ldots$ dose(s) não tomada & $\ldots \ldots$ dose(s) não tomada & $\ldots \ldots$ dose(s) não tomada \\
\hline & $\ldots \ldots$ dose(s) não tomada & $\ldots \ldots$ dose(s) não tomada & $\ldots \ldots$ dose(s) não tomada \\
\hline
\end{tabular}

Agradecemos o tempo que dedicou para preencher este papel, por favor escreva seus comentários no verso 


\section{Anexo 10: Escala de Auto-Eficácia para seguir prescrição anti- retroviral}

Escala de Expectativa de Auto-Eficácia para seguir Prescrição Anti-Retroviral - Versão para os pais/cuidadores

\begin{tabular}{|c|c|c|c|c|c|c|}
\hline & \begin{tabular}{|l|} 
Não vou \\
dar \\
mesmo \\
\end{tabular} & $\begin{array}{l}\text { Acho que } \\
\text { não vou dar }\end{array}$ & $\begin{array}{l}\text { Não } \\
\text { sei }\end{array}$ & $\begin{array}{l}\text { Acho } \\
\text { que vou } \\
\text { dar }\end{array}$ & \begin{tabular}{|l} 
Com \\
certeza \\
vou dar
\end{tabular} & Código \\
\hline $\begin{array}{l}\text { Se a criança/adolescente estiver bem de } \\
\text { saúde. }\end{array}$ & & & & & & AE1 \\
\hline $\begin{array}{l}\text { Se o vírus no sangue da } \\
\text { criança/adolescente for tão pouco que } \\
\text { não aparece na carga viral. }\end{array}$ & & & & & & AE2 \\
\hline $\begin{array}{l}\text { Se a criança/adolescente estiver } \\
\text { aborrecida e se sentindo pra baixo. }\end{array}$ & & & & & & AE3 \\
\hline $\begin{array}{l}\text { Se a criança/adolescente for discriminada } \\
\text { ou rejeitada. }\end{array}$ & & & & & & AE4 \\
\hline $\begin{array}{l}\text { Se a criança/adolescente estiver ocupada } \\
\text { ou se divertindo. }\end{array}$ & & & & & & AE5 \\
\hline $\begin{array}{l}\text { Se a criança/adolescente estiver em } \\
\text { viagem de passeio ou de trabalho. }\end{array}$ & & & & & & AE6 \\
\hline Se a criança/adolescente estiver na rua. & & & & & & AE7 \\
\hline $\begin{array}{l}\text { Se a criança/adolescente estiver se } \\
\text { sentindo doente. }\end{array}$ & & & & & & AE8 \\
\hline $\begin{array}{l}\text { Se a criança/adolescente estiver com } \\
\text { alguém que eu não quero que saiba que } \\
\text { ela é portadora do vírus da AIDS }\end{array}$ & & & & & & AE9 \\
\hline $\begin{array}{l}\text { Se a criança/adolescente tiver de tomar } \\
\text { muitos comprimidos. }\end{array}$ & & & & & & AE10 \\
\hline $\begin{array}{l}\text { Se a criança/adolescente estiver nervosa } \\
\text { ou irritada. }\end{array}$ & & & & & & AE11 \\
\hline $\begin{array}{l}\text { Se a criança/adolescente mudar muito o } \\
\text { médico que a atende. }\end{array}$ & & & & & & AE12 \\
\hline $\begin{array}{l}\text { Se a criança/adolescente tiver de tomar } \\
\text { remédios várias vezes por dia. }\end{array}$ & & & & & & AE13 \\
\hline $\begin{array}{l}\text { Se a criança/adolescente estiver com } \\
\text { pessoas estranhas. }\end{array}$ & & & & & & AE14 \\
\hline Se o remédio for difícil de engolir. & & & & & & AE15 \\
\hline Se for feriado ou final de semana. & & & & & & AE16 \\
\hline $\begin{array}{l}\text { Se a criança/adolescente tiver de mudar o } \\
\text { seu horário de comer ou de dormir. }\end{array}$ & & & & & & AE17 \\
\hline $\begin{array}{l}\text { Se o remédio tiver gosto ruim ou cheiro } \\
\text { forte. }\end{array}$ & & & & & & AE18 \\
\hline $\begin{array}{l}\text { Se a criança/adolescente estiver fazendo } \\
\text { coisas fora da sua rotina. }\end{array}$ & & & & & & AE19 \\
\hline $\begin{array}{l}\text { Se a criança/adolescente estiver com } \\
\text { alguém que acha bobagem ela tomar } \\
\text { esses remédios. }\end{array}$ & & & & & & AE20 \\
\hline $\begin{array}{l}\text { Se os remédios estiverem causando } \\
\text { efeito ruim na criança/adolescente. }\end{array}$ & & & & & & AE21 \\
\hline
\end{tabular}


Anexo 11: Maturação sexual -Critérios de Tanner

Desenvolvimento puberal femininocritérios de tanner

Mamas
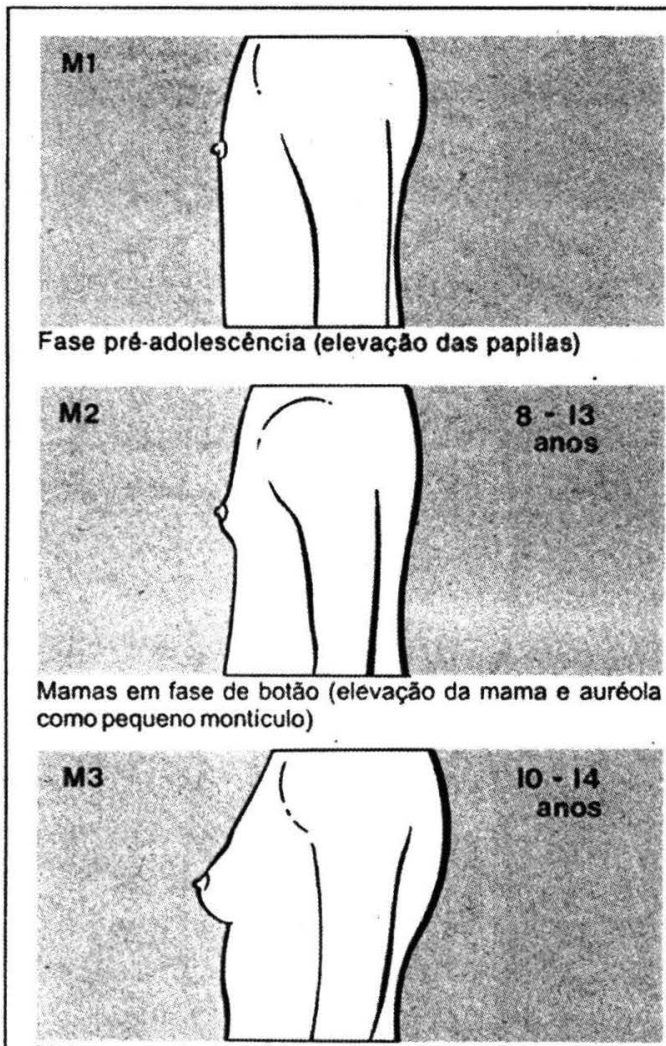

Maior aumento da mama, sem separaçăo dos contornos

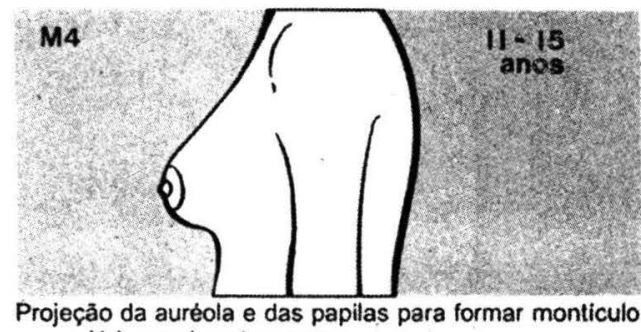
secundário por cima da mama

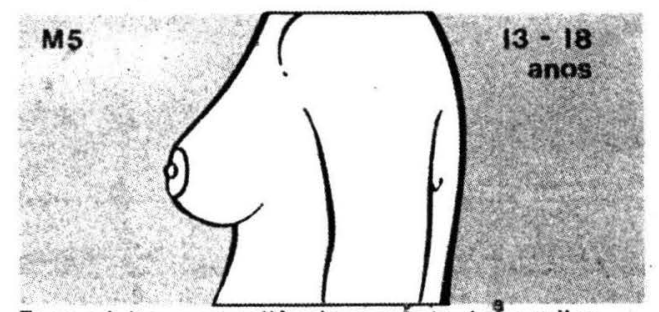

Fase adulta, com saliência somênte das paplias
Pêlos pubianos

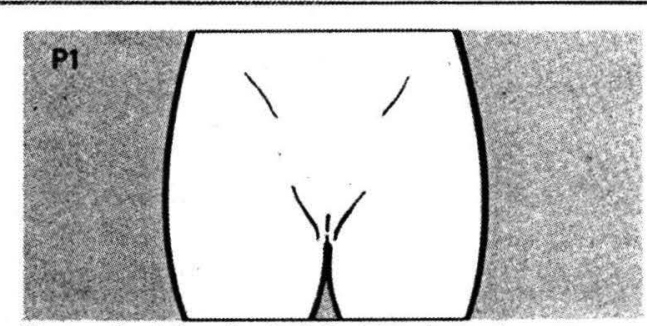

Fase prê-adolescência (năo há pelugem)

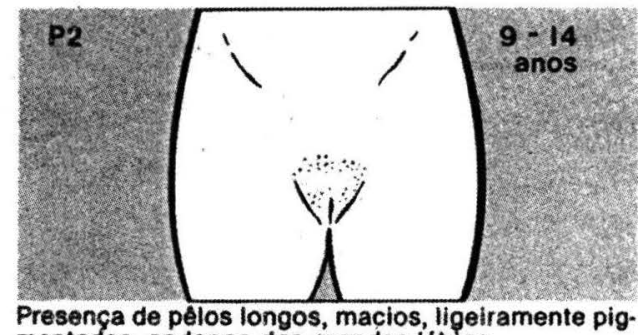
mentados, ao longo dos grandes láblos

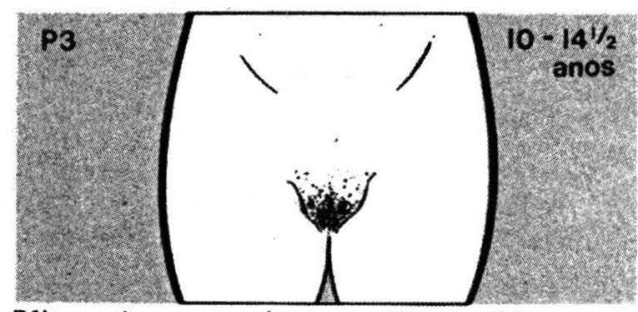

Pólos mais escuros, ásperos, sobre o púbis

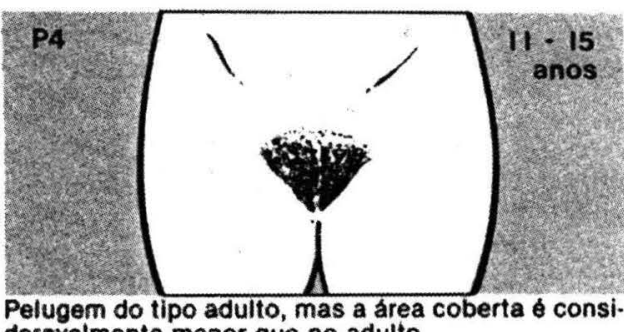
deravelmente menor que no adulto

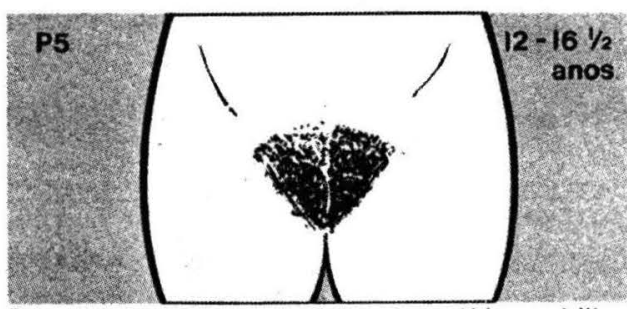

Pelugem tipo adulto, cobrindo todo o púbis e a virilha 


\section{Desenvolvimento puberal masculinocritérios de tanner}

\section{Genitália}

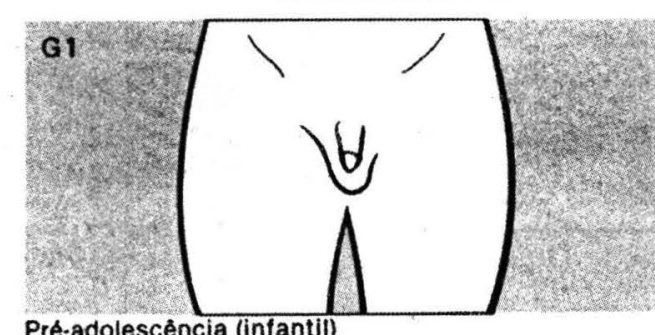

Pré-adolescência (infantii)

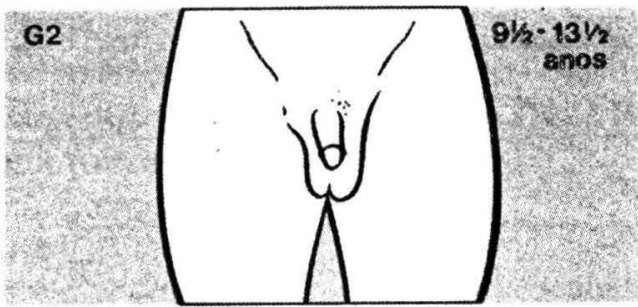

Aumento do escroto e dos testlculos, sem aumento do pernis

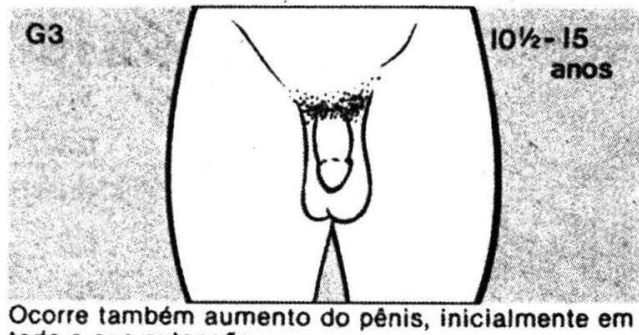
toda a sua extensáo

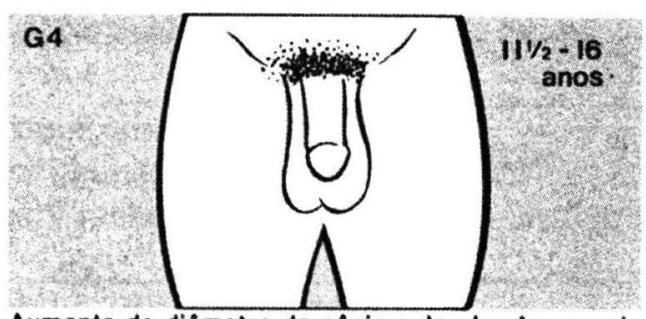

Aumento do diâmetro do pénis e da glande, crescimento dos testiculos e escroto, cuja pele escurece

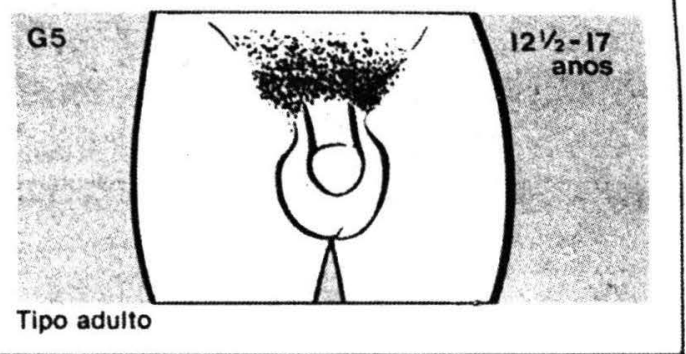

Pêlos pubianos

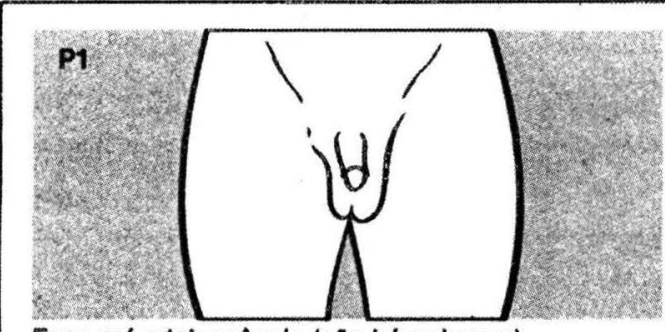

Fase pré-adolescêncla (nåo há pelugem)

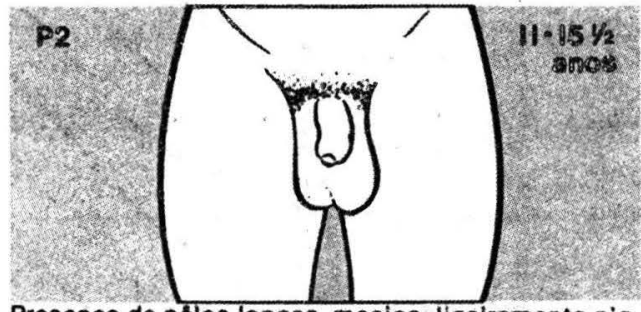

Presenca de pélos longos, macios, ligeiramente pigmentados, na base do pênis

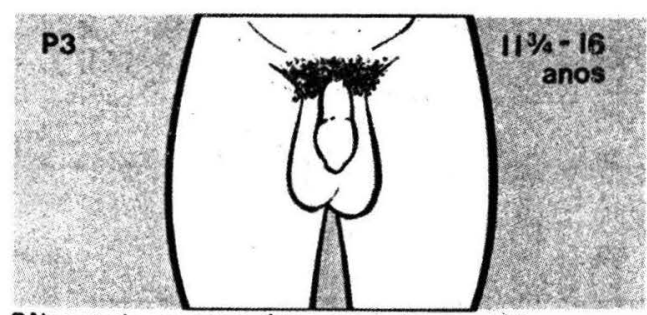

Pélos mais escuros, ásperos, sobre o púbis

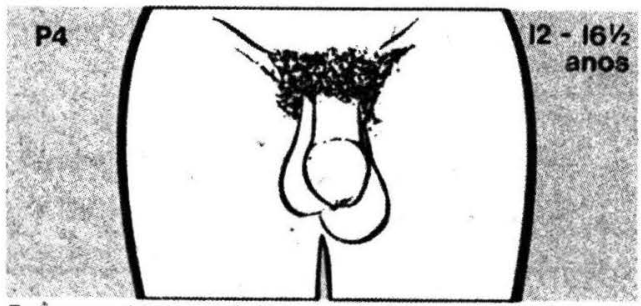

Pelugem do tipo adulto mas a área coberta é consideravelmente menor que no adulto

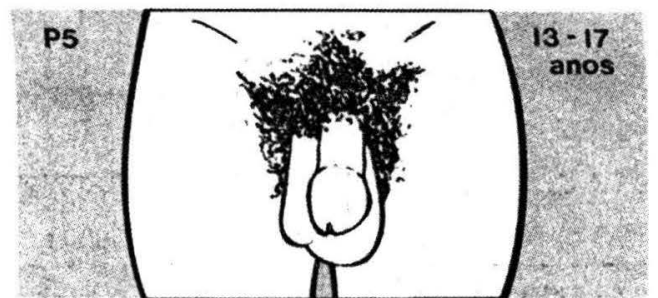

Tipo adulto, estendendo-se até a face interna das coxas 
Anexo 12: Características clínicas da criança/adolescente (dados do prontuário)

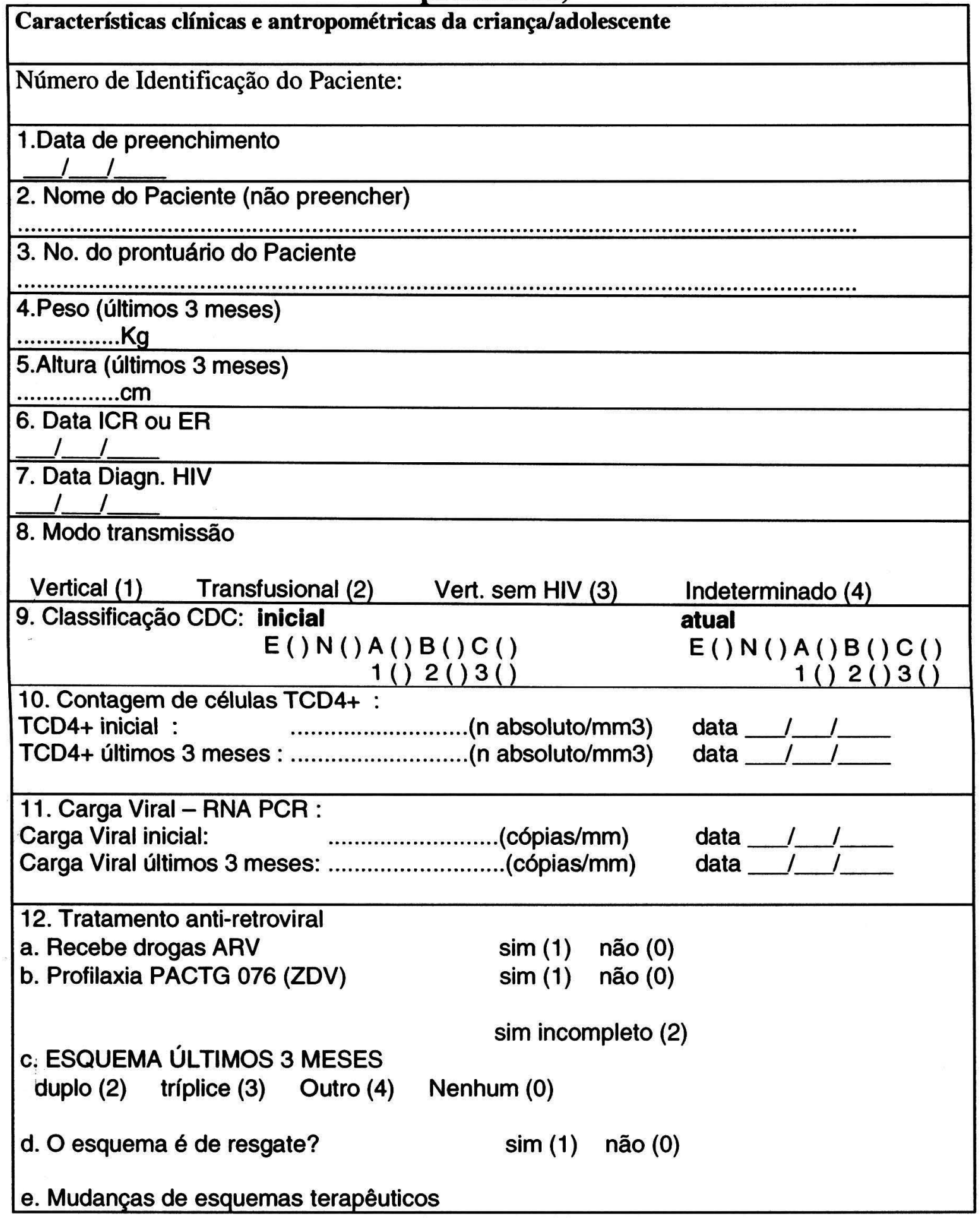




\begin{tabular}{|c|c|c|c|c|c|}
\hline tipo & Data & \multicolumn{4}{|l|}{ motivo } \\
\hline \multicolumn{6}{|l|}{1.} \\
\hline \multicolumn{6}{|l|}{2.} \\
\hline \multicolumn{6}{|l|}{3.} \\
\hline \multicolumn{6}{|l|}{4.} \\
\hline \multicolumn{6}{|l|}{5.} \\
\hline \multicolumn{6}{|l|}{6.} \\
\hline \multirow{2}{*}{\multicolumn{6}{|c|}{$\frac{7 .}{8 .}$}} \\
\hline & & & & & \\
\hline \multirow{2}{*}{\multicolumn{3}{|c|}{\begin{tabular}{|l|l|}
9. & \\
13. Uso de medicamentos ARV \\
\end{tabular}}} & & & \\
\hline & & & $\begin{array}{l}\text { data } \\
\text { início }\end{array}$ & \begin{tabular}{|l} 
data de \\
término
\end{tabular} & Motivo \\
\hline \multirow{2}{*}{\multicolumn{6}{|c|}{$\frac{1}{2}$}} \\
\hline & & & & & 2. \\
\hline \multicolumn{6}{|l|}{3.} \\
\hline \multicolumn{6}{|l|}{4.} \\
\hline \multirow{2}{*}{\multicolumn{6}{|c|}{5.}} \\
\hline & & & & & \\
\hline \\
\hline & & & & & 8. \\
\hline \multirow{2}{*}{\multicolumn{6}{|c|}{\begin{tabular}{|l|}
9. \\
10
\end{tabular}}} \\
\hline & & & & & \\
\hline \multicolumn{3}{|c|}{ 14. Uso de outros medicamentos não ARV } & \begin{tabular}{|l|} 
data \\
início
\end{tabular} & $\begin{array}{l}\text { data de } \\
\text { término }\end{array}$ & Motivo \\
\hline \multicolumn{6}{|l|}{1} \\
\hline \\
\hline \multicolumn{6}{|l|}{$\frac{2 .}{3 .}$} \\
\hline \multicolumn{6}{|l|}{4.} \\
\hline \multicolumn{6}{|l|}{5.} \\
\hline \multicolumn{6}{|l|}{6.} \\
\hline \multicolumn{6}{|l|}{7.} \\
\hline \multicolumn{6}{|l|}{8.} \\
\hline 9. & & & & & \\
\hline 10. & & & & & \\
\hline $\begin{array}{l}\text { 15. Profilaxia PI } \\
\text { 1ária } \operatorname{sim}(1)\end{array}$ & $\begin{array}{l}\text { C } \\
\text { não (0) - data in }\end{array}$ & ício ___ & & & \\
\hline 2ária sim (1) & não (0) - data in & ício ___ I _ & & & \\
\hline $\begin{array}{l}\text { 16. Uso IGEV } r \\
\text { IGEV } \operatorname{sim}(1)\end{array}$ & $\begin{array}{l}\text { ensal } \\
\text { não }(0) \text { - data ir }\end{array}$ & nício 11 & & & \\
\hline
\end{tabular}




\begin{tabular}{|l|l|l|}
\hline 17. Internações & \multicolumn{3}{|l|}{} \\
\hline Motivo & $\begin{array}{l}\text { data } \\
\text { início }\end{array}$ & data de término \\
\hline 1. & & \\
\hline 2. & & \\
\hline 3. & & \\
\hline 4. & & \\
\hline
\end{tabular}




\section{Anexo 13: Fórmulas para o cálculo dos escores}

\section{PACTG 219C General Health Assessment for Children}

In PACTG 219/219C quality of life is assessed by the General Health Assessment for Children (GHAC) developed by Gortmaker, et al., (1998). This instrument is derived and adapted from a variety of quality of life measures with demonstrated reliability and validity that have been previously used and are available to the public.

\section{General approach to calculating QOL Domain Scores.}

- Each domain in the GHAC is scored separately.

- We used a proportional transformation to create consistent scoring for each QOL domain with a range of $0-100$. A score of 100 indicates the best quality of life and 0 indicates the worst.

- In some cases, raw scores need to be reversed before the scale scores are calculated, so that higher scores indicate better quality of life (QOL).

- After reversing scale items when necessary, the QOL domain score is calculated as follows:

QOL Domain Score $=[($ Sum of actual raw scores - lowest possible raw score on the scale)/possible raw score range] X 100.

- Individual QOL domains are summarized below. The table also includes alternative scoring for the psychological functioning and symptoms domains.

\begin{tabular}{|l|l|l|l|}
\hline Domain Name & Questions & Raw Scores & Comments \\
\hline $\begin{array}{l}\text { Avaliação Geral da } \\
\text { Saúde 6 mos-4 years } \\
\text { (General Health } \\
\text { Perceptions) }\end{array}$ & $\begin{array}{l}\text { I.A. 1-3 } \\
6 \text { mos-4 years }\end{array}$ & $\begin{array}{l}\text { Maximum raw score=30 } \\
\text { Minimum raw score=3 } \\
\text { Possible range=27 }\end{array}$ & $\begin{array}{l}\text { No reverse scoring } \\
\text { needed }\end{array}$ \\
\hline $\begin{array}{l}\text { Avaliação Geral da } \\
\text { Saúde 6 mos-4 years } \\
\text { (General Health } \\
\text { Perceptions) }\end{array}$ & $\begin{array}{l}\text { I.A. 1-4 } \\
\text { 5-11, 12-20 years }\end{array}$ & $\begin{array}{l}\text { Maximum raw score=40 } \\
\text { Minimum raw score=4 } \\
\text { Possible range=36 }\end{array}$ & $\begin{array}{l}\text { No reverse scoring } \\
\text { needed. Question 4 } \\
\text { differs between forms } \\
\text { for 5-11 and 12-20 } \\
\text { years. }\end{array}$ \\
\hline $\begin{array}{l}\text { Physical Resilience } \\
\text { 6 months -11 years } \\
\text { (Domain name was not } \\
\text { included on GHAC } \\
\text { form) }\end{array}$ & $\begin{array}{l}\text { I.B. 1-7 6 mos-4 } \\
\text { years \& 5-11 years }\end{array}$ & $\begin{array}{l}\text { Maximum raw score=21 } \\
\text { Minimum raw score=7 } \\
\text { Possible range=14 }\end{array}$ & $\begin{array}{l}\text { Reverse scores of } \\
\text { items 2, 3, 4, 5 before } \\
\text { calculating domain } \\
\text { score }\end{array}$ \\
\hline $\begin{array}{l}\text { Avaliação do Estado } \\
\text { Físico * } \\
\text { 6 mos-4 years } \\
\text { (Functional Status) }\end{array}$ & $\begin{array}{l}\text { II. 1-14 } \\
\text { f mos-4 years } \\
\text { only }\end{array}$ & $\begin{array}{l}\text { Maximum raw score=42 } \\
\text { Minimum raw score=14 } \\
\text { Possible range=18 }\end{array}$ & $\begin{array}{l}\text { Reverse scores of } \\
\text { items 4, 6, 9, 12, 14 } \\
\text { before calculating } \\
\text { domain score }\end{array}$ \\
\hline $\begin{array}{l}\text { Avaliação do Estado } \\
\text { Físico 5-20 years }\end{array}$ & $\begin{array}{l}\text { II. 1-6 } \\
5-11 \text { and 12-20 }\end{array}$ & $\begin{array}{l}\text { Maximum raw score=30 } \\
\text { Minimum raw score=6 }\end{array}$ & $\begin{array}{l}\text { Reverse scores of all } \\
\text { items before }\end{array}$ \\
\hline
\end{tabular}




\begin{tabular}{|c|c|c|c|}
\hline (Physical Functioning) & years & Possible range $=24$ & $\begin{array}{l}\text { calculating domain } \\
\text { score }\end{array}$ \\
\hline $\begin{array}{l}\text { Avaliação da Saúde } \\
\text { Psicologica 5-20 years } \\
\text { (Psychological } \\
\text { Functioning,) }\end{array}$ & $\begin{array}{l}\text { III. 1-28 } \\
5-11 \text { and 12-20 } \\
\text { years }\end{array}$ & $\begin{array}{l}\text { Maximum raw score }=84 \\
\text { Minimum raw score }=28 \\
\text { Possible range }=56\end{array}$ & $\begin{array}{l}\text { No reverse scoring } \\
\text { needed. Questions } \\
24-27 \text { differ between } \\
\text { forms for 5-11 years } \\
\text { and } 12-20 \text { years. }\end{array}$ \\
\hline $\begin{array}{l}\text { Sintomas ou Sinais } \\
4 \text { months-20 years } \\
\text { Symptoms }\end{array}$ & V.1-20 & \begin{tabular}{|l|} 
Maximum raw \\
score $=120$ \\
Minimum raw score $=20$ \\
Possible range $=100$ \\
\end{tabular} & $\begin{array}{l}\text { Reverse scores of all } \\
\text { items before } \\
\text { calculating domain } \\
\text { score }\end{array}$ \\
\hline \begin{tabular}{|l|} 
Avaliação das \\
Atividades Pessoais e \\
Sociais \\
Social and Role** \\
Functioning 6 mos-4 \\
years \\
\end{tabular} & $\begin{array}{l}\text { III. A. } 1 \\
\text { III. B 1-5 } \\
6 \text { mos-4 years }\end{array}$ & $\begin{array}{l}\text { Maximum raw score }=10 \\
\text { Minimum raw score }=5 \\
\text { Possible range }=5\end{array}$ & $\begin{array}{l}\text { Recode question IV } \\
\text { A1 as yes/no before } \\
\text { scoring. }\end{array}$ \\
\hline $\begin{array}{l}\text { Avaliação das } \\
\text { Atividades Pessoais e } \\
\text { Sociais** } \\
\text { Social and Role } \\
\text { Functioning5-20 years } \\
\text { (pages 9-10) } \\
\end{array}$ & $\begin{array}{l}\text { IV A. 1 } \\
\text { IV B } 2,3,4,6\end{array}$ & \begin{tabular}{|l|} 
Maximum raw score $=10$ \\
Minimum raw score $=5$ \\
Possible range $=5$
\end{tabular} & $\begin{array}{l}\text { Recode question IV } \\
\text { A1 as yes/no before } \\
\text { scoring. }\end{array}$ \\
\hline $\begin{array}{l}\text { Alternate Scoring for } \\
\text { Avaliação da Saúde } \\
\text { Psicológica 5-20 } \\
\text { years: } \\
\text { Behavioral Problems } \\
\text { Index (BPI) }\end{array}$ & $\begin{array}{l}\text { III. } 1-28 \\
5-11 \text { and } 12-20 \\
\text { years }\end{array}$ & $\begin{array}{l}\text { Calculate BPI as the } \\
\text { sum of the number of } \\
\text { items with raw scores of } \\
1 \text { or } 2 \text {. } \\
\text { Maximum score }=28 \\
\text { Minimum raw score }=0\end{array}$ & $\begin{array}{l}\text { In this case, you do } \\
\text { not calculate a } \\
\text { domain score. The } \\
\text { BPI score reflects the } \\
\text { number of behavioral } \\
\text { problems. With this } \\
\text { scoring, the higher } \\
\text { score indicates worse } \\
\text { QOL. }\end{array}$ \\
\hline \multicolumn{4}{|l|}{$\begin{array}{l}\text { Behavioral Problem } \\
\text { Index Subscales_See } \\
\text { Table below (pp. 5-6) }\end{array}$} \\
\hline $\begin{array}{l}\text { Alternate Scoring for } \\
\text { Sintomas ou Sinais } \\
4 \text { months-20 years: } \\
\text { Number of moderate } \\
\text { or worse symptoms. }\end{array}$ & V.1-20 & $\begin{array}{l}\text { Calculate symptoms as } \\
\text { the sum of the number } \\
\text { of items with raw scores } \\
\text { of } 4,5 \text {, or } 6 \text {. } \\
\text { Maximum score }=20 \\
\text { Minimum raw score }=0\end{array}$ & $\begin{array}{l}\text { In this case, you do } \\
\text { not calculate a } \\
\text { domain score. The } \\
\text { symptom score } \\
\text { reflects the number } \\
\text { of moderate or } \\
\text { greater symptoms. } \\
\text { With this scoring, the } \\
\text { higher score indicates } \\
\text { worse QOL. }\end{array}$ \\
\hline
\end{tabular}

* "Estado Físico" was used as the heading both for the Functional Status domain on the form for children 6 months to 4 years and for the Physical Functioning domain in the two forms for 
children 5-11 and 12-20 years. In young children, the Functional Status domain provides a composite assessment of physical and psychological function. The forms for older children have both physical functioning and psychological functioning domains that are scored separately. You may want to create names to reflect the different Estado Físico domains for younger and older children.

- Missing data for an individual item can be handled by imputing the mean of an individual's other scores for that domain or by imputing the mean of the group. However, you'll want to make a determination about how many missing items would require dropping the data.

- Scoring Social and role functioning. In some analyses, internal consistency (Cronbach's alpha) has been lower for the social and role functioning domain as compared to the others, so it is considered an index, rather than a scale. It can still be scored on a 0-100 scale. Alternatively, you could calculate the number of social/role limitations (number of items reporting yes). However, when presented with other QOL domain results, it is generally easier to use the same scale. This issue is mentioned in the PACTG 219 article by Storm et. al. and the $219 \mathrm{C}$ article by Lee et. al. Some questions were not included in the summary index score because they were affected by factors other than health. For example, home schooling can be a family decision and participation in school sports may be limited by their availability. However, you may want to reconsider which questions should be included as you conduct your analyses.

- You may want to analyze data for each age group separately, or in some cases you may want to combine data from different age groups. As you know from the instruments, there are some domains and questions that differ by age. You may decide to use domains shared by two age groups in some analyses, particularly in multivariate analyses adjusted for age.

- Negative life events: 1a-r (page 1-2). Calculate as the sum of the number of events that have occurred during the past 12 months.

\section{Sources of OOL domain measures used in the GHAC}

General Health Perceptions (age 0 - 21 years) - This instrument is adapted from the Adult ACTG QOL form (Testa \& Lenderking, 1995). Items are from prior work with adults (Testa \& Simonson, 1996) and comparable to a similar measure used in the National health Interview Survey (Adams \& Marano, 1995).

Functional Status (age 0 - 4 only) - This assessment is the Functional Status II(R) developed by Stein and Jessop (1990) to evaluate functional status in chronically ill children. This measure has been widely used and has demonstrated good reliability and validity in different child populations. 
Physical Function (age 5-20 years) - The items in this measure are from the Adult ACTG QOL form (Testa \& Lenderking, 1995) and based upon the measure developed for the Medical Outcomes Study (Stewart, Hayes, \& Ware, 1988). Essentially this measure examines how health has interfered with physical activities.

Physical Resilience (age 0 - 11 years) - Using questions from the Child Health Supplement to the National Health Interview Survey of 1988 (National Center for Health Statistics, 1989; Brook, Ware, \& Davies-Avery, 1979), this measure evaluates a child's ability to "bounce back" or recover from physical and emotional/psychological challenges.

Psychological Function (age 5 - 21 years)- The measure is the Behavior Problem Index adapted by Zill from the Child Behavior Checklist (CBCL; Achenback \& Edelbrock, 1983). This instrument has been widely used in a variety of child populations to screen for behavior problems that may indicate a child having psychological difficulty. A variety of studies have noted the BPI's ability to discriminate between children with and without chronic illness as well as children being referred for psychological intervention (Gortmaker et al., 1990; McCormick, Brooks-Gunn, Worman-Daniels, Turner, \& Peckham, 1992; Gortmaker, Walker, Weitzman, \& Sobel, 1990).

Symptoms (age 0 - 21 years) - Questions (18) from the Adult ACTG QOL form (Testa \& Lenderking, 1995) were used to assess the "distressingness" of symptoms for a child. Two further questions for diarrhea and earaches (more common in children) were added.

References:

Brook, R. H., Ware, J. E. Jr., \& Davies-Avery, A. (1979). Overview of adult health status measures fielded in Rand's Health Insurance Study. Medical Care. (Supplement) 17, 1-131.

Gortmaker, S. L., Walker, D. K., Weitzman, M., \& sobol, A. (1990). Chronic conditions, socioeconomic risks, and behavioral problems in children and adolescents. Pediatrics, 85, $267-$ 276.

Gortmaker, S. L., Lenderking, W. R., Clark, C., Fowler, M. G., Lee, S., Oleske, J. M. \& The ACTG 219 Team (1998). Development and use of a pediatric quality of life questionnaire in AIDS clinical trials: Reliability and validity of the general health assessment for children. In Drotar, D. (Ed.), Assessing pediatric health-related quality of life and functional status:

Implications for research and Practice. Wahwah, NJ: Lawrence Earlbaum Associates, Inc., 219235.

McCormick, M., Gortmaker, S. L., \& Sobol, A. (1990). Very low birth weight children: behavior problems and school failure in a national sample. Journal of Pediatrics, 117, 687-693.

McCormick, M. Brooks-Gunn, J., Workman-Daniels, K., Turner, J., \& Peckham, G. J. (1992). The health and developmental status of very low-birth-weight children at school age. Journal of the American Medical Association, 267, 2204-2208.

Peterson, J. L., \& Zill, N. (1986). Marital disruption, parent-child relationships, and behavior problems in children. Journal of Marriage and the Family, 48, 295-307. 
Stewart, A. L., Hayes, R. D., \& Ware, J. E. (1988). The MOS short-form general health survey: reliability and validity in a patient population. Medical Care, 26, 724-735.

Testa, M., \& Simonson, D. C. (1996). Assessment of quality-of-life outcomes. New England Journal of Medicine, 313, 835-840.

Testa, M. A., \& Lenderking, W. R. (1995). Quality of life considerations in AIDS clinical trials. In D. M. Finkelstein \& D. A. Schoenfeld (Eds.), AIDS clinical trials. New York: Wiley-Liss, Inc. 


\section{DOUBTIES - March 6, 2006}

\section{Physical resilience (questions I-B1-7).}

You wrote that I should reverse the items 2, 3, 4, 5, but I think that I should reverse the items 3,5 , and 6 . Could you check it, please?

Sorry for the error and confusion. You should reverse items 3, 4, 5, 6. As you look at these items, the best QOL would be "never or rarely (1)". Therefore, the response score should be reversed so that the highest score (3) indicates the best QOL.

\section{Functional status $(6 \mathrm{mo}-4 \mathrm{y})$}

Why the item II-15 was not considered on the score?

I haven't reported on this scale yet so I don't have the best answer. However, some users of the scale do not include this item about specialized medical equipment in the overall score. I might guess this is because it is influenced by a number of external factors and may not be appropriate for the majority of children with certain conditions. I'll try to get some additional information about this. In deciding whether or not to retain this item, you could consider what types of specialized medical equipment are used by children with HIV infection and would be addressed by this question. This would not include medications.

\section{Social and role functioning}

3.1. How should I recode the question III-A 1 into yes(1)/no(2)?

0 days $($ response $=1$ ) $=$ No

$>0$ days $($ response $=2,3,4,5$, or 6$)=$ Yes

3.2. Will not would be easier to calculate de social and role functioning score if $I$ consider the item III-A-1 ranging from 0 to 6 ? In this case, the minimum rank would be 5 and the maximum would be 16 . 
We used simple yes/no scoring for several reasons, including consistency with other items in the domain-which are generally yes/no responses. However, it is appropriate for you to consider and test some alternative scoring strategies for the social and role functioning score. You may want to examine the distribution of the responses and decide how many categories of responses to include, rather than using all 6 responses (from $1=$ no days to $6=>16$ days.)

We found that there was weaker internal consistency for this social and role functioning than for other QOL domains, like general health perceptions or symptoms. Therefore, it seemed to function like an "index" rather than a "scale". You can check internal consistency with Cronbach's alpha and test validity using correlations with clinical indicators, like CD4, or functional indicators like hospitalizations, physical activity, etc.

\subsection{Why the item III-A2 was not included on the social and role functioning score?}

We did not include item III-A2 it because so many children had missing information. Many young children (< 5 years) may not be in school. Missing data was also a problem for the same item on the forms for older children: item IV-A2 (5-11 and $\geq 12$ years). Although the question was supposed to be completed even during vacation periods, there was more missing data for this item than others in this domain. The social and role functioning section for older children has a yes/no question about school attendance (IV-B 3) that we found had much less missing data.

You could include item III-A2 or IV-A2 (depending on the form), if you find that you have less of a problem with missing data. Or you could analyze it separately for those children who have the item completed.

3.4. You wrote that the questions which should be considered on the score for 5-20 years are IV-A1 and IV B 2, 3, 4 and 6. I think you wanted write that the questions are III-A1 and III B 2, 3, 4 and 6, didn't you? 
Because of differences in the domains between age groups, the social and role functioning domain is composed of questions from section III in the form for children 6 months to 4 years. However, in the forms for 5-11 year olds and 12-20 years old, the social and role functioning questions are in section IV. I've attached the forms from you that I'm referring to-just to be sure that there haven't been changes since I received the forms.

3.5. For the 6mo-4 y age group, considering the items III-A1 (yes/no) and III-B 1-5 (yes/no), the minimum rank should be 6 and the maximum should be 12 (not 5 and 10 as you wrote), because there are 6 items (coded 1 or 2). Could you check it, please?

You are correct. I was referring to the forms for older children.

3.6. Why the item III-A2 was not included on the social and role functioning score? See response to question 3.3 , above.

3.6. Why the question III-B5 was not included on the social and role functioning score for 5-20 years?

I think you mean section IV-B5 (see response to question 3.4, above). We did not include this item because issues other than a child's health can affect access to school sports-such as school funding. However, some analyses have included this item, and you may want to include it also. Again, I suggest using Cronbach's alpha to look at internal consistency. Also, check validity with correlations with clinical aspects such as hospitalizations or CD4.

\section{Questions IV-A 1-4 and IV-B 1-6.}

Is there a score for health care utilization?

I guess I have to reverse the items A1-4, and the minimum rank is 6 and the maximum rank is 36 . Am I correct? 
You could create a health care utilization score. If you want it to be like the other domains, you would reverse the scores in section IV-A so that higher scores would be better-i.e., indicate less health care utilization. The minimum raw score for the items in part IV-A would be 4 and the maximum would be 24. The score for section IV-B I6 would range from 6 to 12 . Combining section $I V-A$ and $I V-B$, total healthcare utilization scores would range from a minimum score of 10 to a maximum score of 36. You could also transform the scores like the other $Q O L$ domains to a range of 0 to 100.

Thanks in advance for your help, best regards,

Rosario 
Anexo 14: Aprovação do comitê de ética em pesquisa da Faculdade de Saúde Pública da Universidade de São Paulo 


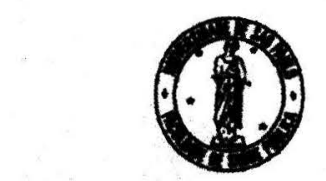

\section{Universidade de São Paulo}

Faculdade de Saúde Pública

COMTTE DE ATCA-COEP

Av. Dr. Arnaldo, 715 - CEP 01246-904 - Såo Paulo - Brasil Telefones: (55-11) 3066- 7779 - fone/fax (55-11) 3064 -7314 - o-mail: mdracas@usp.br

\section{Ot.COEP/028/04}

19 de fevereiro de 2004

Pelo presente, informo que o Comitê de Ética em Pesquisa da Faculdade de Saúde Pública da Universidade de São Paulo-COEP, analisou e aprovou em sua 1.\%04 Sessăo Extraordinária, realizada em 19.02.04, de acordo com os requisitos da Resolução CNS/196/96, o Protocolo de Pesquisa n. 1079, intitulado: "QUALIDADE DE VIDA EM CRIANÇAS E ADOLESCENTES COM HIV/AIDS ", apresentado pela pesquisadora Luciana Scarlazarri Costa.

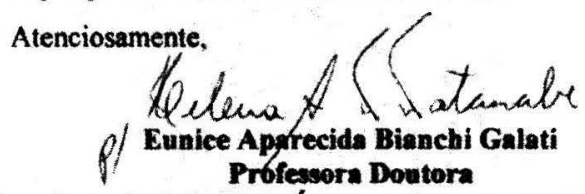

Coordenadora do Comitê de Ética em Pesquisa da FSP-COEP 
Anexo 15: Aprovação do comitê de ética em pesquisa do Centro de Referência e Treinamento em DST/AIDS 
Oficio CRT-DST/AIDS - CEP n. $057 / 05$ PROTOCOLO CEP n. $001 / 05$ " "Validaçăo e Reprodutibilidade de
Questionários de Qualidade de Vida Especificos para Crianças e
Adolescentes com HIVIAIDS".

Senhora Investigadora

Após a análise do referido projeto pelos membros deste Comité, em reuniăo ordinária do dia 21/03/2005, foi emitido parecer: APROVADO, com a seguinte recomendaçăo:

No Termo de Consentimento Livre e Esclarecido - TCLE, no item que afirma: que "Em caso de dúvidas ou perguntas referentes a sua participaçäo no estudos..." você poderá também entrar em contato com o Coordenador do Comitê de Ética em Pesquisa, do CRT-DSTIAIDS, Dr. Eduardo Ronner Lagonegro pelo telefone: $5087-9837$, das $8: 30$ as $12: 30 \mathrm{~h}$, diariamente.

Solicitamos que nos seja enviado, com periodicidade de seis meses a contar desta data, um comunicado sucinto sobre o andamento do Projeto

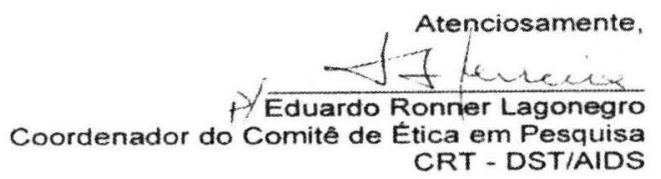

IIma. Sra

Luciana Scariazzari Costa

Investigador Principal

Centro de Referencia e Treinamento DSTIAIDS

Rua Santa Cruz, 81 . Ambuiatono sala 1

CEP OA121.000 SaOPaulor SF

Fonelf ax: $5087-3837$
- - mail: cepert.saude.sp.gov.br 


\section{Anexo 16: Tabelas com a distribuição das notas para cada questão do questionário de qualidade de vida}

Faixa etária de 6 meses a 4 anos

\section{AVALIAÇÃO GERAL DA SAÚDE}

$\underline{\text { Avaliação geral da saúde: }}$

Tabela 1: Número de crianças segundo a primeira parte das questões do domínio de avaliação geral da saúde. CRT/SP, março 2005.

\begin{tabular}{l|cccccccccc|c}
\hline Pergunta & $\mathbf{1}$ & $\mathbf{2}$ & $\mathbf{3}$ & $\mathbf{4}$ & $\mathbf{5}$ & $\mathbf{6}$ & $\mathbf{7}$ & $\mathbf{8}$ & $\mathbf{9}$ & $\mathbf{1 0}$ & Total \\
$\begin{array}{l}\text { I. Como sua criança } \\
\text { tem se sentido nos }\end{array}$ & & & & & & & & & & & \\
últimos 3 meses? & & & & & & & & & & & \\
\hline $\mathrm{n}=35$ & & & & & & & & & & & \\
1. De maneira geral? & - & - & - & - & 2 & 1 & 2 & 5 & 6 & 19 & 35 \\
2. Fisicamente? & - & - & - & - & - & 1 & 1 & 7 & 3 & 23 & 35 \\
3. Emocionalmente? & - & - & - & 1 & 2 & 2 & 4 & 6 & 4 & 16 & 35 \\
\hline
\end{tabular}

Escore total da avaliação geral da saúde: média=88,15 ( $\mathrm{DP}=10,99)$; mediana=88,89; mínimo=59,26 máximo=100,00; alpha Cronbach $=0,41$ 


\section{Resistência Física:}

Tabela 2: Número de crianças segundo a segunda parte das questões do domínio de avaliação geral da saúde, do questionário de qualidade de vida. CRT/SP, março 2005.

\begin{tabular}{l|ccc|c}
\hline Pergunta & $\begin{array}{c}\text { Nunca } \\
\text { ou } \\
\text { raramen } \\
\text { te }\end{array}$ & $\begin{array}{c}\text { Durante } \\
\text { algum } \\
\text { tempo }\end{array}$ & $\begin{array}{c}\text { Quase } \\
\text { sempre } \\
\text { ou } \\
\text { sempre }\end{array}$ & Total \\
II. Durante os 3 últimos meses... & - & 8 & 27 & 35 \\
\hline $\begin{array}{l}\text { 1. A saúde de minha criança é excelente } \\
\text { 2. Minha criança parece resistir a doença muito bem }\end{array}$ & 1 & 5 & 29 & 35 \\
$\begin{array}{l}\text { 3.Minha criança parece menos sadia do que outras } \\
\text { crianças que eu conheço }\end{array}$ & 30 & 2 & 3 & 35 \\
$\begin{array}{l}\text { 4. Minha criança é bastante suscetível a doenças que } \\
\text { estão circulando }\end{array}$ & 22 & 9 & 4 & 35 \\
$\begin{array}{l}\text { 5. Minha criança é pouco desajeitada } \\
\text { 6. Minha criança parece ter uma tendência a sofrer } \\
\text { acidentes }\end{array}$ & 21 & 9 & 5 & 35 \\
$\begin{array}{l}\text { 7. Quando minha criança está doente ou machucada, } \\
\text { ela geralmente se recupera rapidamente }\end{array}$ & - & 25 & 8 & 35 \\
\hline
\end{tabular}

Escore total da Resistência Física: média $=65,10 \quad(D P=10,36)$; mediana $=64,29$; mínimo=42,86 máximo $=85,71$; alpha Cronbach $=0,10$ 


\section{AVALIAÇÃO DO ESTADO FÍSICO}

Tabela 3: Número de crianças segundo as questões do domínio de Avaliação do Estado Físico. CRT/SP, março 2005.

\begin{tabular}{l|ccc|c}
\hline Pergunta & $\begin{array}{c}\text { Nunca } \\
\text { ou } \\
\text { raramen } \\
\text { te }\end{array}$ & $\begin{array}{c}\text { Durante } \\
\text { algum } \\
\text { tempo }\end{array}$ & $\begin{array}{c}\text { Quase } \\
\text { sempre } \\
\text { ou } \\
\text { sempre }\end{array}$ & Total \\
\hline 1. Se alimentado bem & 1 & 6 & 28 & 35 \\
2. Dormido bem & 1 & 8 & 26 & 35 \\
3. Parece contente e alegre & - & 3 & 32 & 35 \\
4. Muda de humor sem razão aparente? & 15 & 13 & 7 & 35 \\
5. Comunica, pede o que está querendo? & 1 & 1 & 33 & 35 \\
6. Parece se sentir doente ou cansada? & 29 & 4 & 2 & 35 \\
7. Se ocupa fazendo coisas, brincando sozinha & 2 & 6 & 27 & 35 \\
8. Parece animada, ativa e cheia de energia & - & 1 & 34 & 35 \\
9. Parece irritada, zangada ou mal humorada? & 14 & 20 & 1 & 35 \\
10. Dorme a noite toda? & 2 & 7 & 26 & 35 \\
11. Reage aos seus estímulos? & - & 2 & 33 & 35 \\
12. Parece estar mais difícil de lidar do que o & 18 & 8 & 9 & 35 \\
costume? & & & & \\
13.Parece interessada no que está acontecendo ao & 1 & 1 & 33 & 35 \\
redor? & & & & \\
14. Reage com choro a pequenas coisas? & 8 & 9 & 18 & 35 \\
15. Depende de algum equipamento ou aparelho & 35 & - & - & 35 \\
médico no seu dia a dia? & & & & \\
\hline
\end{tabular}

Escore total da Avaliação do Estado Físico: média= 81,73 (DP=10,39); mediana=82,14; mínimo $=60,71$ máximo $=100,00$; alpha Cronbach $=0,30$ 


\section{AVALIAÇÃO DAS ATIVIDADES PESSOAIS E SOCIAIS}

O escore desse domínio é formado pelos dados das Tabelas 4 e 5 . A estatística descritiva do escore total da Avaliação das Atividades Pessoais e Sociais são: média= 75,43 $(\mathrm{DP}=12,91)$; mediana $=80,00$; mínimo $=40,00$ máximo $=100,00$; alpha Cronbach $=$ inválido

Tabela 4: Número de crianças segundo a primeira parte das questões do domínio de Avaliação das Atividades Pessoais e Sociais.

\begin{tabular}{l|cccccc|c}
\hline $\begin{array}{l}\text { Pergunta } \\
\begin{array}{l}\text { I. DURANTE AS 4 ÚlTIMAS } \\
\text { SEMANAS, QUANTOS DIAS... }\end{array}\end{array}$ & $\mathbf{0}$ & $\mathbf{1 - 2}$ & $\mathbf{3 - 5}$ & $\mathbf{6 - 1 0}$ & $\mathbf{1 1 - 1 5}$ & $\mathbf{> 1 6}$ & Total \\
\hline $\begin{array}{l}\text { 1. A sua criança ficou na cama devido } \\
\text { a alguma doença ou lesão/ferimento? }\end{array}$ & 29 & 1 & 3 & 1 & - & 1 & 35 \\
$\begin{array}{l}\text { 2. A doença ou lesão manteve sua } \\
\text { criança fora da escola/creche? }\end{array}$ & 34 & - & 1 & - & - & - & 35 \\
\hline
\end{tabular}


Tabela 5: Número de crianças segundo a segunda parte das questões do domínio de Avaliação das Atividades Pessoais e Sociais.

\begin{tabular}{|c|c|c|}
\hline Pergunta & Categoria & $\mathbf{N}^{0}$ \\
\hline \multirow{3}{*}{$\begin{array}{l}\text { II. DURANTE AS ÚLTIMAS 4 SEMANAS... } \\
\text { 1. Sua criança teve alguma doença ou lesão que limitou ou } \\
\text { impediu que ela fizesse alguma das atividades infantis tais como } \\
\text { brincar com outras crianças ou participar de jogos e esportes? }\end{array}$} & & \\
\hline & SIM & 6 \\
\hline & NÃO & 29 \\
\hline \multirow{2}{*}{$\begin{array}{l}\text { 2. No geral, sua criança esteve capaz de participar das atividades } \\
\text { rotineiras com as outras crianças? }\end{array}$} & SIM & 30 \\
\hline & NÃO & 5 \\
\hline \multirow[t]{2}{*}{$\begin{array}{l}\text { 3. No geral, sua criança esteve limitada no tipo de brincadeira } \\
\text { devido à sua saúde? }\end{array}$} & SIM & 4 \\
\hline & NÃO & 31 \\
\hline \multirow{2}{*}{$\begin{array}{l}\text { 4. No geral, sua criança esteve limitada na quantidade, ou melhor, } \\
\text { no tempo de brincar devido à sua saúde? }\end{array}$} & SIM & 3 \\
\hline & NÃO & 32 \\
\hline \multirow{2}{*}{$\begin{array}{l}\text { 5. Sua criança está envolvida em programa de estimulação precoce } \\
\text { devido à sua saúde? }\end{array}$} & SIM & 0 \\
\hline & NÃO & 35 \\
\hline \multirow{6}{*}{$\begin{array}{l}\text { 6. DURANTE AS ÚLTIMAS } 4 \text { SEMANAS, quem cuidou de sua } \\
\text { criança na maioria do tempo durante os dias da semana? }\end{array}$} & Pai/mãe & 23 \\
\hline & Avós & 3 \\
\hline & Não parente & 1 \\
\hline & Creche & 4 \\
\hline & Maternal/Jardim & 2 \\
\hline & Outras pessoas & 2 \\
\hline TOTAL & & 35 \\
\hline
\end{tabular}




\section{SINTOMAS OU SINAIS}

Tabela 6: Número de crianças segundo o domínio de Sintomas ou Sinais.

\begin{tabular}{|c|c|c|c|c|c|c|c|}
\hline $\begin{array}{l}\text { Pergunta } \\
\text { O quanto de desconforto a } \\
\text { criança sentiu com esses } \\
\text { Sintomas ou Sinais nas últimas } 4 \\
\text { semanas? }\end{array}$ & $\begin{array}{c}\text { Nem } \\
\text { um } \\
\text { pouco }\end{array}$ & $\begin{array}{l}\text { Muito } \\
\text { pouco }\end{array}$ & Pouco & $\begin{array}{c}\text { Modera } \\
\text { damente } \\
\text { (mais ou } \\
\text { menos) }\end{array}$ & Muito & Demais & Total \\
\hline 1. dor física ou no corpo todo? & 25 & 4 & 4 & 1 & 1 & - & 35 \\
\hline 2. chiado, tosse? & 16 & 3 & 8 & 3 & 5 & - & 35 \\
\hline $\begin{array}{l}\text { 3. náuseas, vômitos, dor } \\
\text { abdominal, dor de estômago? }\end{array}$ & 25 & 4 & 1 & 4 & 1 & - & 35 \\
\hline 4. diarréia? & 25 & 4 & 3 & 2 & 1 & - & 35 \\
\hline $\begin{array}{l}\text { 5. manchas, coceiras ou outros } \\
\text { problemas de pele? }\end{array}$ & 22 & 2 & 5 & 3 & 3 & - & 35 \\
\hline 6. fadiga, cansaço, fraqueza? & 32 & 1 & 2 & - & - & - & 35 \\
\hline 7. tontura, delírio febril? & 35 & - & - & - & - & - & 35 \\
\hline $\begin{array}{l}\text { 8. febre, suores noturnos, } \\
\text { tremores e calafrios? }\end{array}$ & 28 & 1 & 3 & 1 & 2 & - & 35 \\
\hline 9. perda de apetite? & 20 & 5 & 4 & 5 & 1 & - & 35 \\
\hline 10. problemas de sono? & 26 & 5 & 3 & - & 1 & - & 35 \\
\hline $\begin{array}{l}\text { 11. problemas nos olhos ou para } \\
\text { enxergar? }\end{array}$ & 33 & - & - & - & 2 & - & 35 \\
\hline 12. dor de cabeça? & 33 & 1 & - & 1 & - & - & 35 \\
\hline $\begin{array}{l}\text { 13. boca seca ou dolorida, } \\
\text { problemas para engolir? }\end{array}$ & 34 & 1 & - & - & - & - & 35 \\
\hline 14. dor ou aperto no peito? & 32 & 1 & 1 & 1 & - & - & 35 \\
\hline $\begin{array}{l}\text { 15. dificuldade para respirar ou } \\
\text { pegar o ar? }\end{array}$ & 27 & 2 & 4 & 1 & 1 & - & 35 \\
\hline $\begin{array}{l}\text { 16. nariz escorrendo ou } \\
\text { problemas de sinusite? }\end{array}$ & 17 & 3 & 7 & 3 & 4 & 1 & 35 \\
\hline $\begin{array}{l}\text { 17. dor no músculo, nas } \\
\text { articulações (juntas) ou nos }\end{array}$ & 34 & 1 & - & - & - & - & 35 \\
\hline
\end{tabular}




\begin{tabular}{|c|c|c|c|c|c|c|c|}
\hline \multicolumn{8}{|l|}{ ossos? } \\
\hline $\begin{array}{l}\text { 18. dor, formigamento, } \\
\text { dormência, paralisia nas mãos } \\
\text { ou pés? }\end{array}$ & 34 & 1 & - & - & - & - & 35 \\
\hline 19. dor de ouvido? & 29 & 1 & 4 & 1 & - & - & 35 \\
\hline $\begin{array}{l}\text { 20. desconforto ou mal estar } \\
\text { geral? }\end{array}$ & 21 & 6 & 3 & 4 & 1 & - & 35 \\
\hline
\end{tabular}

Escore total dos Sintomas ou Sinais : média=90,37 $(\mathrm{DP}=8,50)$; mediana=93,0; mínimo= 70,00 máximo $=100,00 ;$ alpha Cronbach $=0,78$ 
Faixa etária de 5 a 11 anos

\section{AVALIAÇÃO GERAL DA SAÚDE}

\section{Avaliação geral da saúde:}

Tabela 7: Número de crianças segundo a primeira parte das questões do domínio de avaliação geral da saúde. CRT/SP, março 2005.

\begin{tabular}{|c|c|c|c|c|c|c|c|c|c|c|c|}
\hline $\begin{array}{l}\text { Pergunta } \\
\text { I. Como sua criança } \\
\text { tem se sentido nos } \\
\text { últimos } 3 \text { meses? }\end{array}$ & $\mathbf{1}$ & 2 & 3 & 4 & 5 & 6 & 7 & 8 & 9 & 10 & Total \\
\hline $\mathrm{n}=35$ & & & & & & & & & & & \\
\hline 1. De maneira geral? & - & - & 1 & - & 2 & 3 & 2 & 10 & 3 & 14 & 35 \\
\hline 2. Fisicamente? & - & - & - & - & 1 & 3 & 4 & 6 & 3 & 18 & 35 \\
\hline 3. Emocionalmente? & & - & 2 & 3 & 5 & 5 & 2 & 10 & 2 & 6 & 35 \\
\hline $\begin{array}{l}\text { 4. Acerca de sua } \\
\text { atividade em sala de } \\
\text { aula }\end{array}$ & - & 1 & 1 & 3 & 4 & 1 & 2 & 5 & 4 & 14 & 35 \\
\hline
\end{tabular}

Escore total da avaliação geral da saúde: média=77,5 (DP=17,11); mediana=80,56; mínimo=41,67 máximo $=100,00$; alpha Cronbach $=0,76$ 


\section{Resistência Física:}

Tabela 8: Número de crianças segundo a segunda parte das questões do domínio de avaliação geral da saúde, do questionário de qualidade de vida. CRT/SP, março 2005.

\begin{tabular}{|c|c|c|c|c|}
\hline $\begin{array}{l}\text { Pergunta } \\
\text { II. Durante os } 3 \text { últimos meses... }\end{array}$ & $\begin{array}{l}\text { Nunca } \\
\text { ou } \\
\text { raramen } \\
\text { te }\end{array}$ & $\begin{array}{l}\text { Durante } \\
\text { algum } \\
\text { tempo }\end{array}$ & $\begin{array}{l}\text { Quase } \\
\text { sempre } \\
\text { ou } \\
\text { sempre }\end{array}$ & Total \\
\hline 1. A saúde de minha criança é excelente & - & 10 & 25 & 35 \\
\hline 2. Minha criança parece resistir a doença muito bem & - & 8 & 27 & 35 \\
\hline $\begin{array}{l}\text { 3.Minha criança parece menos sadia do que outras } \\
\text { crianças que eu conheço }\end{array}$ & 25 & 5 & 5 & 35 \\
\hline $\begin{array}{l}\text { 4. Minha criança é bastante suscetível a doenças que } \\
\text { estão circulando }\end{array}$ & 21 & 7 & 7 & 35 \\
\hline 5. Minha criança é pouco desajeitada & 20 & 6 & 9 & 35 \\
\hline $\begin{array}{l}\text { 6. Minha criança parece ter uma tendência a sofrer } \\
\text { acidentes }\end{array}$ & 26 & 7 & 2 & 35 \\
\hline $\begin{array}{l}\text { 7. Quando minha criança está doente ou machucada, } \\
\text { ela geralmente se recupera rapidamente }\end{array}$ & - & 4 & 31 & 35 \\
\hline
\end{tabular}

Escore total da Resistência Física: média=60,20 ( $D P=11,27)$; mediana=64,29; mínimo=35,71 máximo=78,57; alpha Cronbach $=0,13$ 


\section{AVALIAÇÃO DO ESTADO FISICO}

Tabela 9: Número de crianças segundo as questões do domínio de Avaliação do Estado Físico. CRT/SP, março 2005.

\begin{tabular}{|c|c|c|c|c|c|c|}
\hline $\begin{array}{l}\text { Pergunta } \\
\text { Nas últimas } 4 \text { semanas... } \\
\text { O quanto que a saúde de sua } \\
\text { criança interferiu com... }\end{array}$ & $\begin{array}{l}\text { Nada/ne } \\
\text { m um } \\
\text { pouco }\end{array}$ & $\underset{\text { pouco }}{\text { Um }}$ & $\begin{array}{c}\text { Moderada } \\
\text { mente } \\
\text { (mais ou } \\
\text { menos) }\end{array}$ & Muito & Demais & Total \\
\hline $\begin{array}{l}\text { 1. o tipo ou quantidade de } \\
\text { atividades vigorosas }\end{array}$ & 22 & 8 & 4 & - & 1 & 35 \\
\hline $\begin{array}{l}\text { 2. o tipo ou quantidade de } \\
\text { atividades moderadas }\end{array}$ & 28 & 4 & 2 & - & 1 & 35 \\
\hline $\begin{array}{l}\text { 3. caminhar, subir rampa ou } \\
\text { subir alguns lances de } \\
\text { escadas? }\end{array}$ & 21 & 7 & 4 & 1 & 2 & 35 \\
\hline 4. caminhar uma quadra? & 24 & 5 & 5 & - & 1 & 35 \\
\hline 5. agachar, curvar, levantar? & 25 & 4 & 3 & 1 & 2 & 35 \\
\hline $\begin{array}{l}\text { 6. comer, se vestir, tomar } \\
\text { banho ou ir ao banheiro? }\end{array}$ & 26 & 5 & 3 & - & 1 & 35 \\
\hline
\end{tabular}

Escore total da Avaliação do Estado Físico: média=86,55(DP=20,24); mediana=91,67; mínimo $=0$ máximo $=100,00$; alpha Cronbach $=0,90$ 


\section{AVALIAÇÃO DA SAÚDE PSICOLÓGICA}

Tabela 10: Número de crianças segundo as questões do domínio de Avaliação da Saúde Psicológica, do questionário de qualidade de vida. CRT/SP, março 2005.

\begin{tabular}{|c|c|c|c|c|}
\hline Pergunta & $\begin{array}{c}\text { Muitas } \\
\text { vezes }\end{array}$ & $\begin{array}{l}\text { Algumas } \\
\text { vezes }\end{array}$ & Nunca & Total \\
\hline $\begin{array}{l}\text { 1. Minha criança tem mudanças súbitas de humor ou } \\
\text { sentimentos }\end{array}$ & 5 & 26 & 4 & 35 \\
\hline 2. Minha criança sente ou reclama que ninguém a ama & 1 & 14 & 20 & 35 \\
\hline 3. Minha criança é muito tensa ou nervosa & 9 & 20 & 6 & 35 \\
\hline 4. Minha criança engana ou conta mentiras & 5 & 13 & 17 & 35 \\
\hline 5. Minha criança é medrosa ou ansiosa & 7 & 22 & 6 & 35 \\
\hline 6. Minha criança argumenta demais & 13 & 17 & 5 & 35 \\
\hline $\begin{array}{l}\text { 7. Minha criança tem dificuldade de se concentrar, } \\
\text { não presta atenção por muito tempo }\end{array}$ & 6 & 24 & 5 & 35 \\
\hline $\begin{array}{l}\text { 8. Minha criança se confunde facilmente, parece estar } \\
\text { um pouco fora do ar ou no mundo da lua }\end{array}$ & 6 & 15 & 14 & 35 \\
\hline $\begin{array}{l}\text { 9. Minha criança é intimidadora ou é cruel ou com os } \\
\text { outros }\end{array}$ & 2 & 8 & 25 & 35 \\
\hline 10. Minha criança é desobediente em casa & 5 & 20 & 10 & 35 \\
\hline 11. Minha criança é desobediente na escola & 2 & 8 & 25 & 35 \\
\hline $\begin{array}{l}\text { 12. Minha criança não fica arrependida depois de se } \\
\text { comportar mal }\end{array}$ & 3 & 10 & 22 & 35 \\
\hline $\begin{array}{l}\text { 13. Minha criança tem problemas em se relacionar } \\
\text { com outras crianças }\end{array}$ & - & 7 & 28 & 35 \\
\hline $\begin{array}{l}\text { 14. Minha criança tem problemas de se relacionar } \\
\text { com os professores }\end{array}$ & 1 & 7 & 27 & 35 \\
\hline 15. Minha criança é impulsiva, age sem pensar & 2 & 15 & 18 & 35 \\
\hline $\begin{array}{l}\text { 16. Minha criança sente-se inútil, sem valor ou } \\
\text { inferior }\end{array}$ & - & 10 & 25 & 35 \\
\hline 17. Minha criança não é querida pelas outras crianças & - & 6 & 29 & 35 \\
\hline 18. Minha criança tem muita dificuldade em tirar & 3 & 12 & 20 & 35 \\
\hline
\end{tabular}


certas idéias da cabeça (tem obsessões)

19. Minha criança é irrequieta ou superativa, não consegue ficar sentada

20. Minha criança é teimosa, emburrada, irritadiça

21. Minha criança tem o temperamento muito forte e perde a paciência facilmente

22. Minha criança é infeliz, triste ou deprimida

23. Minha criança é fechada, não se envolve com as outras

24. Minha criança é muito dependente dos outros

25. Minha criança quebra coisas de propósito, destrói suas coisas ou as coisas de outras pessoas

26. Minha criança fica muito apegada aos adultos

27. Minha criança chora demais

28. Minha criança solicita muita atenção

\begin{tabular}{|ccc|c}
14 & 16 & 5 & 35 \\
6 & 20 & 9 & 35 \\
7 & 19 & 9 & 35 \\
- & 9 & 26 & 35 \\
1 & 7 & 27 & 35 \\
2 & 13 & 20 & 35 \\
1 & 8 & 26 & 35 \\
14 & 15 & 6 & 35 \\
3 & 14 & 18 & 35 \\
15 & 14 & 6 & 35 \\
\hline
\end{tabular}

Escore total da Avaliação da Saúde Psicológica: média=66,58 (DP=11,49); mediana=67,86; mínimo $=35,71$ máximo $=89,29 ;$ alpha Cronbach $=0,77$ 


\section{AVALIAÇÃO DAS ATIVIDADES PESSOAIS E SOCIAIS}

O escore desse domínio é formado pelos dados das Tabelas 14 e 15 . A estatística descritiva do escore total da avaliação da Atividades Pessoais e Sociais são: média=71,90 ( $\mathrm{DP}=13,27) ;$ mediana=83,33; mínimo=50,00 máximo=83,33; alpha Cronbach $=$ inválido

Tabela 11: Número de crianças segundo a primeira parte das questões do domínio de Avaliação das Atividades Pessoais e Sociais. CRT/SP, março 2005.

\begin{tabular}{l|cccccc|c}
\hline $\begin{array}{l}\text { Pergunta } \\
\begin{array}{l}\text { I. DURANTE AS 4 ÚLTIMAS } \\
\text { SEMANAS, QUANTOS DIAS... }\end{array}\end{array}$ & $\mathbf{0}$ & $\mathbf{1 - 2}$ & $\mathbf{3 - 5}$ & $\mathbf{6 - 1 0}$ & $\mathbf{1 1 - 1 5}$ & $\mathbf{> 1 6}$ & Total \\
\hline $\begin{array}{l}\text { 1. A sua criança ficou na cama devido } \\
\text { a alguma doença ou lesão/ferimento? }\end{array}$ & 29 & 3 & 3 & - & - & - & 35 \\
$\begin{array}{l}\text { 2. A doença ou lesão manteve sua } \\
\text { criança fora da escola/creche? }\end{array}$ & 28 & 5 & 2 & - & - & - & 35 \\
\hline
\end{tabular}


Tabela 12: Número de crianças segundo a segunda parte das questões do domínio de Avaliação das Atividades Pessoais e Sociais. CRT/SP, março 2005.

\begin{tabular}{|c|c|c|}
\hline $\begin{array}{l}\text { Pergunta } \\
\text { II. Assinalar uma resposta... }\end{array}$ & Categoria & $\mathbf{N}^{\mathbf{0}}$ \\
\hline 1. Sua criança repetiu alguma série? & $\begin{array}{l}\text { SIM } \\
\text { NÃO }\end{array}$ & 6 \\
\hline $\begin{array}{l}\text { 2. No geral, sua criança teve a frequiência na escola } \\
\text { comprometida devido à sua condição de saúde? }\end{array}$ & $\begin{array}{l}\text { SIM } \\
\text { NÃO }\end{array}$ & 5 \\
\hline $\begin{array}{l}\text { 3. No geral sua criança esteve limitada no tipo ou na } \\
\text { quantidade de outras atividades devido à sua saúde? }\end{array}$ & $\begin{array}{l}\text { SIM } \\
\text { NÃO }\end{array}$ & 2 \\
\hline $\begin{array}{l}\text { 4. No geral, sua criança participa das atividades } \\
\text { esportivas na escola?. }\end{array}$ & $\begin{array}{l}\text { SIM } \\
\text { NÃO }\end{array}$ & $\begin{array}{l}31 \\
4\end{array}$ \\
\hline $\begin{array}{l}\text { 5. Sua criança freqüenta classe especial ou necessita de } \\
\text { ajuda especial na escola devido a incapacidade ou } \\
\text { problema de saúde? }\end{array}$ & $\begin{array}{l}\text { SIM } \\
\text { NÃO }\end{array}$ & $\begin{array}{l}9 \\
26\end{array}$ \\
\hline TOTAL & & 35 \\
\hline
\end{tabular}




\section{SINTOMAS OU SINAIS}

Tabela 13: Número de crianças segundo o domínio de Sintomas ou Sinais.

\begin{tabular}{|c|c|c|c|c|c|c|c|}
\hline $\begin{array}{l}\text { Pergunta } \\
\text { O quanto de desconforto a } \\
\text { criança sentiu com esses } \\
\text { Sintomas ou Sinais nas últimas } 4 \\
\text { semanas? }\end{array}$ & $\begin{array}{c}\text { Nem } \\
\text { um } \\
\text { pouco }\end{array}$ & $\begin{array}{l}\text { Muito } \\
\text { pouco }\end{array}$ & Pouco & $\begin{array}{c}\text { Modera } \\
\text { damente } \\
\text { (mais ou } \\
\text { menos) }\end{array}$ & Muito & Demais & Total \\
\hline 1. dor física ou no corpo todo? & 18 & 7 & 8 & 1 & 1 & - & 35 \\
\hline 2. chiado, tosse? & 15 & 10 & 6 & 2 & 2 & - & 35 \\
\hline $\begin{array}{l}\text { 3. náuseas, vômitos, dor } \\
\text { abdominal, dor de estômago? }\end{array}$ & 22 & 3 & 5 & 2 & 2 & 1 & 35 \\
\hline 4. diarréia? & 27 & 5 & - & 1 & 2 & - & 35 \\
\hline $\begin{array}{l}\text { 5. manchas, coceiras ou outros } \\
\text { problemas de pele? }\end{array}$ & 20 & 6 & 6 & 2 & 1 & - & 35 \\
\hline 6. fadiga, cansaço, fraqueza? & 23 & 5 & 6 & - & - & 1 & 35 \\
\hline 7. tontura, delírio febril? & 27 & 3 & 5 & - & - & - & 35 \\
\hline $\begin{array}{l}\text { 8. febre, suores noturnos, } \\
\text { tremores e calafrios? }\end{array}$ & 22 & 4 & 5 & 1 & 3 & - & 35 \\
\hline 9. perda de apetite? & 23 & 3 & 3 & 4 & 1 & 1 & 35 \\
\hline 10. problemas de sono? & 29 & 1 & 1 & 3 & 1 & - & 35 \\
\hline $\begin{array}{l}\text { 11. problemas nos olhos ou para } \\
\text { enxergar? }\end{array}$ & 28 & 3 & - & 2 & 2 & - & 35 \\
\hline 12. dor de cabeça? & 19 & 6 & 5 & 2 & 3 & - & 35 \\
\hline $\begin{array}{l}\text { 13. boca seca ou dolorida, } \\
\text { problemas para engolir? }\end{array}$ & 30 & 2 & 1 & 1 & 1 & - & 35 \\
\hline 14. dor ou aperto no peito? & 33 & 2 & - & - & - & - & 35 \\
\hline $\begin{array}{l}\text { 15. dificuldade para respirar ou } \\
\text { pegar o ar? }\end{array}$ & 29 & - & 5 & 1 & - & - & 35 \\
\hline $\begin{array}{l}\text { 16. nariz escorrendo ou } \\
\text { problemas de sinusite? }\end{array}$ & 15 & 10 & 3 & 2 & 3 & 2 & 35 \\
\hline $\begin{array}{l}\text { 17. dor no músculo, nas } \\
\text { articulações (juntas) ou nos } \\
\text { ossos? }\end{array}$ & 23 & 5 & 5 & 1 & - & 1 & 35 \\
\hline
\end{tabular}




\begin{tabular}{|c|c|c|c|c|c|c|c|}
\hline $\begin{array}{l}\text { 18. dor, formigamento, } \\
\text { dormência, paralisia nas mãos } \\
\text { ou pés? }\end{array}$ & 30 & 2 & 1 & 1 & - & 1 & 35 \\
\hline 19. dor de ouvido? & 30 & 2 & 1 & 2 & - & - & 35 \\
\hline $\begin{array}{l}\text { 20. desconforto ou mal estar } \\
\text { geral? }\end{array}$ & 15 & 11 & 5 & 3 & 1 & - & 35 \\
\hline
\end{tabular}

Escore total dos Sintomas ou Sinais : média= 87,09 (DP=11,44); mediana=92,00; mínimo $=59,00$ máximo $=100,00$; alpha Cronbach $=0,85$ 


\subsection{Faixa etária de 12 a 20 anos}

\section{AVALIAÇÃO GERAL DA SAÚDE}

\section{Avaliação geral da saúde:}

Tabela 14: Número de adolescentes segundo a primeira parte das questões do domínio de avaliação geral da saúde. CRT/SP, março 2005.

\begin{tabular}{|c|c|c|c|c|c|c|c|c|c|c|c|}
\hline $\begin{array}{l}\text { Pergunta } \\
\text { I. Como sua criança } \\
\text { tem se sentido nos } \\
\text { últimos } 3 \text { meses? }\end{array}$ & 1 & 2 & 3 & 4 & 5 & 6 & 7 & 8 & 9 & 10 & Total \\
\hline $\mathrm{n}=20$ & & & & & & & & & & & \\
\hline 1. De maneira geral? & - & - & 1 & - & 1 & - & - & 3 & 3 & 12 & 20 \\
\hline 2. Fisicamente? & - & - & 1 & - & 3 & - & 1 & 1 & 3 & 11 & 20 \\
\hline 3. Emocionalmente? & - & 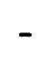 & 1 & 1 & 1 & 2 & 4 & 4 & - & 7 & 20 \\
\hline $\begin{array}{l}\text { 4. Acerca de sua } \\
\text { atividade em sala de } \\
\text { aula }\end{array}$ & - & - & 1 & - & 1 & 3 & 3 & 3 & 2 & 7 & 20 \\
\hline
\end{tabular}

Escore total da avaliação geral da saúde: média=80,83 ( $\mathrm{DP}=19,29)$; mediana=83,33; mínimo=22,00 máximo $=100,00$; alpha Cronbach $=0,85$ 


\section{AVALIAÇÃO DO ESTADO FÍSICO}

Tabela 15: Número de adolescentes segundo as questões do domínio de Avaliação do Estado Físico. CRT/SP, março 2005.

\begin{tabular}{|c|c|c|c|c|c|c|}
\hline $\begin{array}{l}\text { Pergunta } \\
\text { Nas últimas } 4 \text { semanas... } \\
\text { O quanto que a saúde de sua } \\
\text { criança interferiu com... }\end{array}$ & $\begin{array}{l}\text { Nada/ne } \\
\text { m um } \\
\text { pouco }\end{array}$ & $\underset{\text { pouco }}{\text { Um }}$ & $\begin{array}{c}\text { Moderada } \\
\text { mente } \\
\text { (mais ou } \\
\text { menos) }\end{array}$ & Muito & Demais & Total \\
\hline $\begin{array}{l}\text { 1. o tipo ou quantidade de } \\
\text { atividades vigorosas }\end{array}$ & 12 & 4 & 1 & 1 & 2 & 20 \\
\hline $\begin{array}{l}\text { 2. o tipo ou quantidade de } \\
\text { atividades moderadas }\end{array}$ & 15 & 1 & 2 & 1 & 1 & 20 \\
\hline $\begin{array}{l}\text { 3. caminhar, subir rampa ou } \\
\text { subir alguns lances de } \\
\text { escadas? }\end{array}$ & 15 & 2 & - & 1 & 2 & 20 \\
\hline 4. caminhar uma quadra? & 18 & - & - & 1 & 1 & 20 \\
\hline 5. agachar, curvar, levantar? & 16 & - & - & 2 & 2 & 20 \\
\hline $\begin{array}{l}\text { 6. comer, se vestir, tomar } \\
\text { banho ou ir ao banheiro? }\end{array}$ & 17 & 1 & - & - & 2 & 20 \\
\hline
\end{tabular}

Escore total da Avaliação do Estado Físico: média=85,00 (DP=27,52); mediana=100,00; mínimo=0 máximo=100,00; alpha Cronbach $=0,93$ 


\section{AVALIAÇÃO DA SAÚDE PSICOLÓGICA}

Tabela 16: Número de adolescentes segundo as questões do domínio de Avaliação da Saúde Psicológica, do questionário de qualidade de vida. CRT/SP, março 2005.

\begin{tabular}{|c|c|c|c|c|}
\hline Pergunta & $\begin{array}{l}\text { Muitas } \\
\text { vezes }\end{array}$ & $\begin{array}{l}\text { Algumas } \\
\text { vezes }\end{array}$ & Nunca & Total \\
\hline \multicolumn{5}{|l|}{$\mathrm{n}=20$} \\
\hline $\begin{array}{l}\text { 1. Minha criança tem mudanças súbitas de humor ou } \\
\text { sentimentos }\end{array}$ & 3 & 13 & 4 & 20 \\
\hline 2. Minha criança sente ou reclama que ninguém a ama & 2 & 3 & 15 & 20 \\
\hline 3. Minha criança é muito tensa ou nervosa & 4 & 11 & 5 & 20 \\
\hline 4. Minha criança engana ou conta mentiras & 3 & 8 & 9 & 20 \\
\hline 5. Minha criança é medrosa ou ansiosa & 4 & 10 & 6 & 20 \\
\hline 6. Minha criança argumenta demais & 10 & 7 & 3 & 20 \\
\hline $\begin{array}{l}\text { 7. Minha criança tem dificuldade de se concentrar, } \\
\text { não presta atenção por muito tempo }\end{array}$ & 4 & 12 & 4 & 20 \\
\hline $\begin{array}{l}\text { 8. Minha criança se confunde facilmente, parece estar } \\
\text { um pouco fora do ar ou no mundo da lua }\end{array}$ & 4 & 10 & 6 & 20 \\
\hline $\begin{array}{l}\text { 9. Minha criança é intimidadora ou é cruel ou com os } \\
\text { outros }\end{array}$ & - & 3 & 17 & 20 \\
\hline 10. Minha criança é desobediente em casa & 3 & 6 & 11 & 20 \\
\hline 11. Minha criança é desobediente na escola & - & 1 & 19 & 20 \\
\hline $\begin{array}{l}\text { 12. Minha criança não fica arrependida depois de se } \\
\text { comportar mal }\end{array}$ & 1 & 6 & 13 & 20 \\
\hline $\begin{array}{l}\text { 13. Minha criança tem problemas em se relacionar } \\
\text { com outras crianças }\end{array}$ & 3 & 2 & 15 & 20 \\
\hline $\begin{array}{l}\text { 14. Minha criança tem problemas de se relacionar } \\
\text { com os professores }\end{array}$ & 1 & 3 & 16 & 20 \\
\hline 15. Minha criança é impulsiva, age sem pensar & 1 & 10 & 9 & 20 \\
\hline $\begin{array}{l}\text { 16. Minha criança sente-se inútil, sem valor ou } \\
\text { inferior }\end{array}$ & 1 & 2 & 17 & 20 \\
\hline 17. Minha criança não é querida pelas outras crianças & 1 & 2 & 17 & 20 \\
\hline
\end{tabular}


18. Minha criança tem muita dificuldade em tirar certas idéias da cabeça (tem obsessões)

19. Minha criança é irrequieta ou superativa, não consegue ficar sentada

20. Minha criança é teimosa, emburrada, irritadiça

21. Minha criança tem o temperamento muito forte $\mathrm{e}$ perde a paciência facilmente

22. Minha criança é infeliz, triste ou deprimida

23. Minha criança é fechada, não se envolve com as outras

24. Minha criança é muito dependente dos outros

25. Minha criança se sente perseguida o tempo todo pelos outros

26. Minha criança procura ficar com jovens que estão com problemas disciplinares

27. Minha criança mantém suas coisas para si mesma

28. Minha criança preocupa-se muito

\begin{tabular}{|ccc|c}
5 & 8 & 7 & 20 \\
4 & 9 & 7 & 20 \\
5 & 11 & 4 & 20 \\
6 & 6 & 8 & 20 \\
2 & 2 & 16 & 20 \\
1 & 6 & 13 & 20 \\
5 & 6 & 9 & 20 \\
1 & 4 & 15 & 20 \\
- & - & 20 & 20 \\
\hline 7 & 9 & 4 & 20 \\
5 & 12 & 3 & 20 \\
\hline
\end{tabular}

Escore total da Avaliação da Saúde Psicológica: média=68,40 (DP=13,81); mediana $=73,21 ;$ mínimo $=26,79$ máximo $=83,93$; alpha Cronbach $=0,83$ 


\section{AVALIAÇÃO DAS ATIVIDADES PESSOAIS E SOCIAIS}

O escore desse domínio é formado pelos dados das Tabelas 20 e 21 . A estatística descritiva do escore total da Avaliação das Atividades Pessoais e Sociais são: média=67,5 (DP=19,85); mediana=66,67; mínimo=16,67 máximo=100,00; alpha Cronbach $=$ inválido

Tabela 17: Número de adolescentes segundo a primeira parte das questões do domínio de Avaliação das Atividades Pessoais e Sociais. CRT/SP, março 2005.

\begin{tabular}{l|cccccc|c}
\hline $\begin{array}{l}\text { Pergunta } \\
\begin{array}{l}\text { I. DURANTE AS 4 ÚLTIMAS } \\
\text { SEMANAS, QUANTOS DIAS... }\end{array}\end{array}$ & 0 & $1-2$ & $3-5$ & $6-10$ & $11-15$ & $>16$ & Total \\
\hline $\begin{array}{l}\text { 1. A sua criança ficou na cama devido } \\
\text { a alguma doença ou lesão/ferimento? }\end{array}$ & 15 & 1 & 3 & - & - & 1 & 20 \\
$\begin{array}{l}\text { 2. A doença ou lesão manteve sua } \\
\text { criança fora da escola/creche? }\end{array}$ & 12 & 3 & 4 & - & - & 1 & 20 \\
\hline
\end{tabular}


Tabela 18: Número de adolescentes segundo a segunda parte das questões do domínio de Avaliação das Atividades Pessoais e Sociais. CRT/SP, março 2005.

\begin{tabular}{|c|c|c|}
\hline $\begin{array}{l}\text { Pergunta } \\
\text { II. Assinalar uma resposta... }\end{array}$ & Categoria & $\mathbf{N}^{\circ}$ \\
\hline 1. Sua criança repetiu alguma série? & $\begin{array}{l}\text { SIM } \\
\text { NÃO }\end{array}$ & $\begin{array}{l}10 \\
10\end{array}$ \\
\hline $\begin{array}{l}\text { 2. No geral, sua criança teve a frequiência na escola } \\
\text { comprometida devido à sua condição de saúde? }\end{array}$ & SIM & 5 \\
\hline $\begin{array}{l}\text { 3. No geral sua criança esteve limitada no tipo ou na } \\
\text { quantidade de outras atividades devido à sua saúde? }\end{array}$ & $\begin{array}{l}\text { SIM } \\
\text { NÃO }\end{array}$ & $\begin{array}{l}3 \\
17\end{array}$ \\
\hline $\begin{array}{l}\text { 4. No geral, sua criança participa das atividades } \\
\text { esportivas na escola?. }\end{array}$ & $\begin{array}{l}\text { SIM } \\
\text { NÃO }\end{array}$ & $\begin{array}{l}13 \\
7\end{array}$ \\
\hline $\begin{array}{l}\text { 5. Sua criança freqüenta classe especial ou necessita de } \\
\text { ajuda especial na escola devido a incapacidade ou } \\
\text { problema de saúde? }\end{array}$ & $\begin{array}{l}\text { SIM } \\
\text { NÃO }\end{array}$ & $\begin{array}{r}3 \\
17\end{array}$ \\
\hline TOTAL & & 20 \\
\hline
\end{tabular}




\section{SINTOMAS OU SINAIS}

Tabela 19: Número de adolescentes segundo o domínio de Sintomas ou Sinais.

\begin{tabular}{|c|c|c|c|c|c|c|c|}
\hline $\begin{array}{l}\text { Pergunta } \\
\text { O quanto de desconforto a } \\
\text { criança sentiu com esses } \\
\text { Sintomas ou Sinais nas últimas } 4 \\
\text { semanas? }\end{array}$ & $\begin{array}{c}\text { Nem } \\
\text { um } \\
\text { pouco }\end{array}$ & $\begin{array}{l}\text { Muito } \\
\text { pouco }\end{array}$ & Pouco & $\begin{array}{r}\text { Modera } \\
\text { damente } \\
\text { (mais ou } \\
\text { menos) }\end{array}$ & Muito & Demais & Total \\
\hline 1. dor física ou no corpo todo? & 9 & 5 & 3 & 2 & - & 1 & 20 \\
\hline 2. chiado, tosse? & 13 & 4 & 1 & 1 & 1 & - & 20 \\
\hline $\begin{array}{l}\text { 3. náuseas, vômitos, dor } \\
\text { abdominal, dor de estômago? }\end{array}$ & 12 & 3 & 3 & 2 & - & - & 20 \\
\hline 4. diarréia? & 14 & 2 & 3 & 1 & - & - & 20 \\
\hline $\begin{array}{l}\text { 5. manchas, coceiras ou outros } \\
\text { problemas de pele? }\end{array}$ & 11 & 5 & 1 & 1 & 1 & 1 & 20 \\
\hline 6. fadiga, cansaço, fraqueza? & 14 & 3 & - & 2 & 1 & - & 20 \\
\hline 7. tontura, delírio febril? & 17 & 3 & - & - & - & - & 20 \\
\hline $\begin{array}{l}\text { 8. febre, suores noturnos, } \\
\text { tremores e calafrios? }\end{array}$ & 18 & 1 & - & 1 & - & - & 20 \\
\hline 9. perda de apetite? & 17 & 2 & - & - & 1 & - & 20 \\
\hline 10. problemas de sono? & 14 & 2 & 3 & 1 & - & - & 20 \\
\hline $\begin{array}{l}\text { 11. problemas nos olhos ou para } \\
\text { enxergar? }\end{array}$ & 13 & 3 & - & 1 & 2 & 1 & 20 \\
\hline 12. dor de cabeça? & 6 & 10 & - & 3 & 1 & - & 20 \\
\hline $\begin{array}{l}\text { 13. boca seca ou dolorida, } \\
\text { problemas para engolir? }\end{array}$ & 17 & 2 & - & 1 & - & - & 20 \\
\hline 14. dor ou aperto no peito? & 19 & 1 & - & - & - & - & 20 \\
\hline $\begin{array}{l}\text { 15. dificuldade para respirar ou } \\
\text { pegar o ar? }\end{array}$ & 17 & - & 2 & 1 & - & - & 20 \\
\hline $\begin{array}{l}\text { 16. nariz escorrendo ou } \\
\text { problemas de sinusite? }\end{array}$ & 10 & 5 & 3 & 1 & 1 & - & 20 \\
\hline $\begin{array}{l}\text { 17. dor no músculo, nas } \\
\text { articulações (juntas) ou nos } \\
\text { ossos? }\end{array}$ & 13 & 2 & 3 & - & 2 & - & 20 \\
\hline
\end{tabular}




\begin{tabular}{|c|c|c|c|c|c|c|c|}
\hline $\begin{array}{l}\text { 18. dor, formigamento, } \\
\text { dormência, paralisia nas mãos } \\
\text { ou pés? }\end{array}$ & 15 & 4 & - & 1 & - & - & 20 \\
\hline 19. dor de ouvido? & 18 & 1 & 1 & - & - & - & 20 \\
\hline $\begin{array}{l}\text { 20. desconforto ou mal estar } \\
\text { geral? }\end{array}$ & 8 & 7 & 3 & 2 & - & - & 20 \\
\hline
\end{tabular}

Escore total dos Sintomas ou Sinais : média= 88,25 (DP=9,86); mediana=90,50; mínimo $=60,00$ máximo=99,00; alpha Cronbach $=0,82$ 